\title{
BULL TROUT POPULATION ASSESSMENT IN THE WHITE SALMON AND KLICKITAT RIVERS, COLUMBIA RIVER GORGE, WASHINGTON
}

Fiscal Year 2001 Annual Report

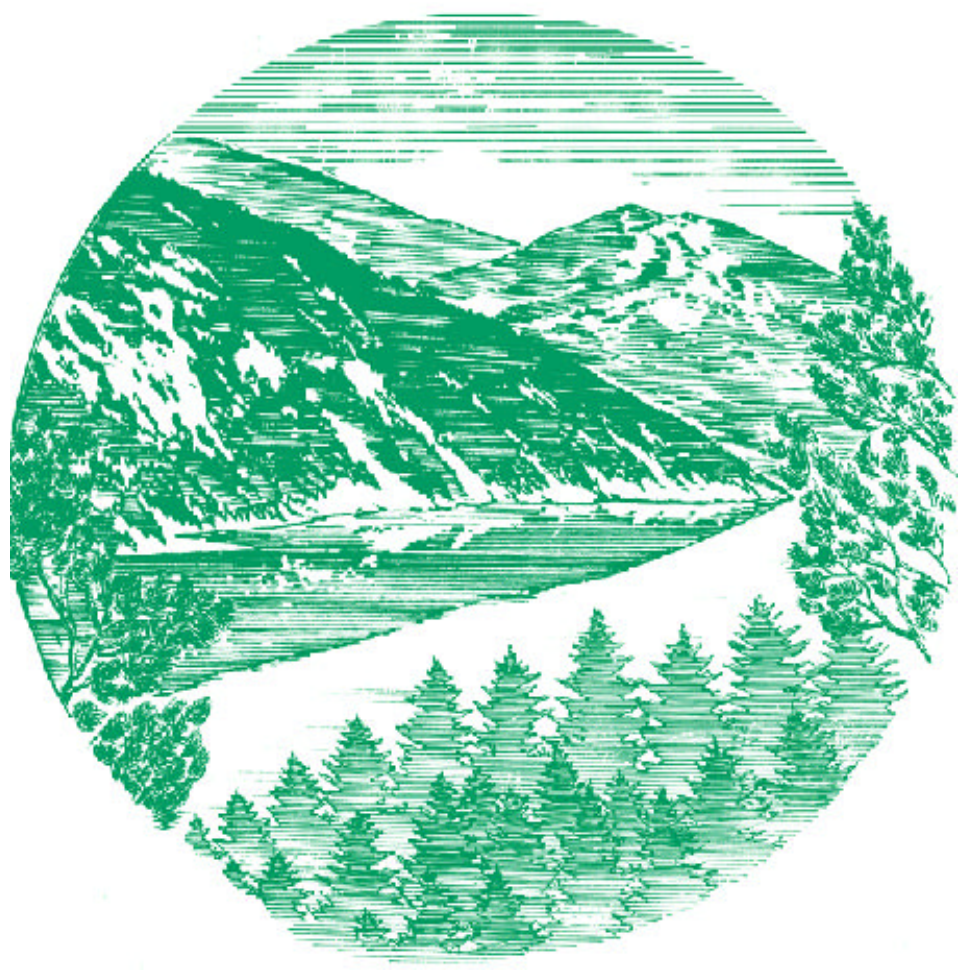

DOE/BP-00004474-1 
This report was funded by the Bonneville Power Administration (BPA), U.S. Department of Energy, as part of BPA's program to protect, mitigate, and enhance fish and wildlife affected by the development and operation of hydroelectric facilities on the Columbia River and its tributaries. The views of this report are the author's and do not necessarily represent the views of BPA.

This document should be cited as follows:

Thiesfeld, Steven L., Ronald H. McPeak, Brian S. McNamara - Washington Department of Fish and Wildlife, Fiscal Year 2001 Annual Report, Bull Trout Population Assessment in the White Salmon and Klickitat Rivers, Columbia River Gorge, Washington, Report to Bonneville Power Administration, Contract No. 00004474, Project No. 199902400, 77 electronic pages (BPA Report DOE/BP-00004474-1)

This report and other BPA Fish and Wildlife Publications are available on the Internet at:

\section{http://www.efw.bpa.gov/cgi-bin/efw/FW/publications.cgi}

For other information on electronic documents or other printed media, contact or write to:

Bonneville Power Administration

Environment, Fish and Wildlife Division

P.O. Box 3621

905 N.E. 11th Avenue

Portland, OR 97208-3621

Please include title, author, and DOE/BP number in the request. 
Fiscal Year 2001

ANNUAL REPORT

Bull Trout Population Assessment in the White Salmon and Klickitat rivers, Columbia River Gorge, Washington

By

Steven L. Thiesfeld

Ronald H. McPeak

Brian S. McNamara

Washington Department of Fish and Wildlife

2108 Grand Blvd.

Vancouver, Washington 98661

and

Isadore Honanie

Confederated Tribes and Bands

Yakama Nation

Post Office Box 151

Toppenish, Washington 98948

BPA Contract \#00004474-00001

Project \# 1999-024-00 


\section{TABLE OF CONTENTS}

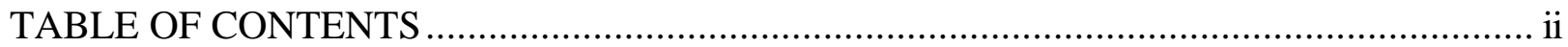

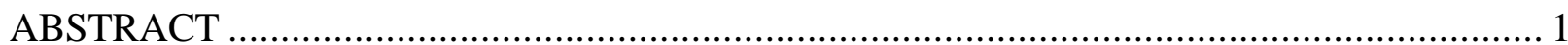

INTRODUCTION

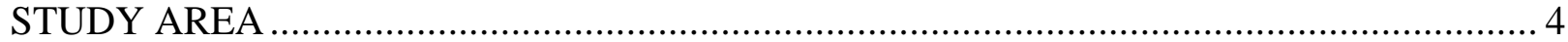

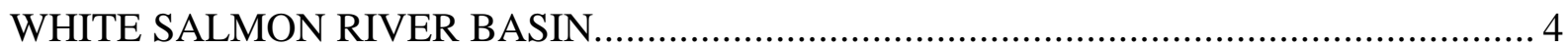

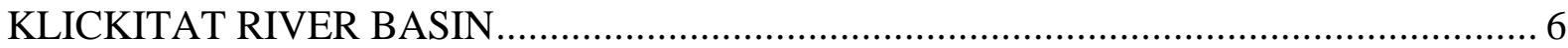

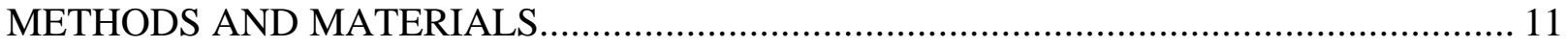

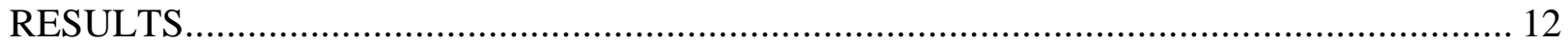

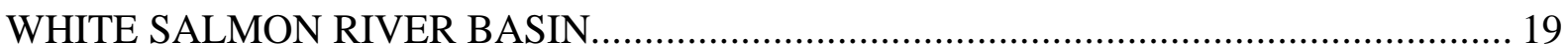

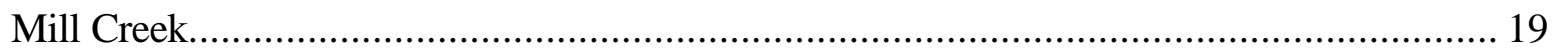

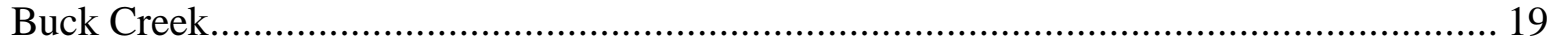

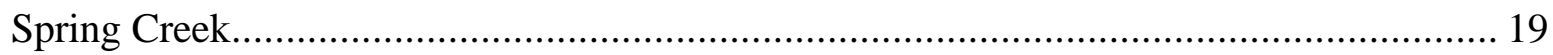

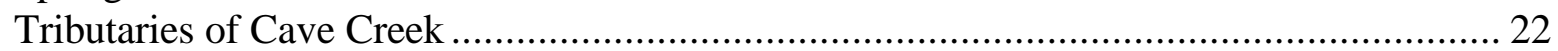

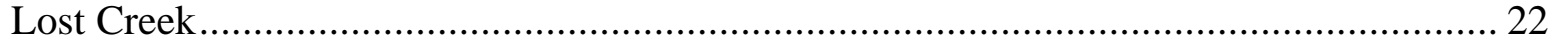

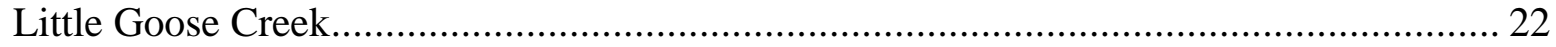

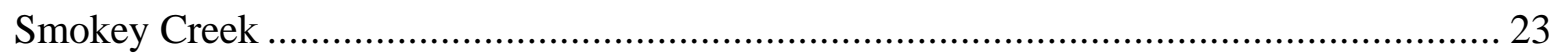

Cultus Creek

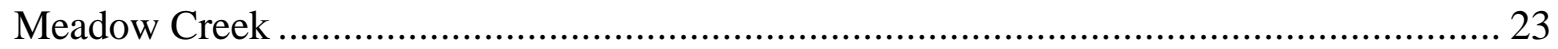

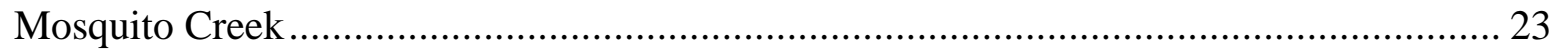

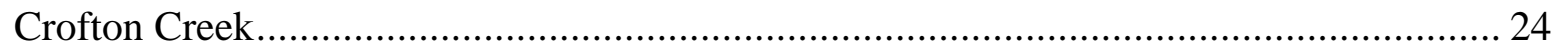

Unnamed Tributaries to White Salmon River................................................................. 24

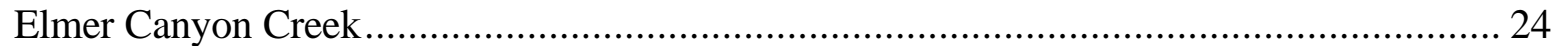

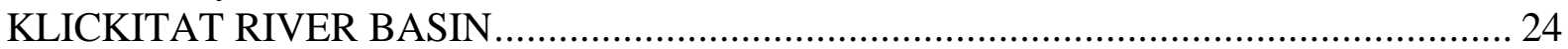

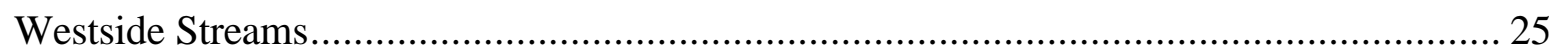

Westside Creeks - Klickitat to Leidl Bridge ……………............................................. 25

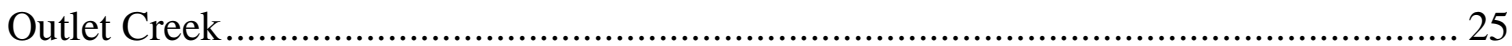

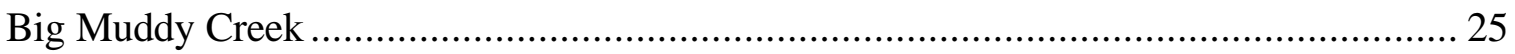

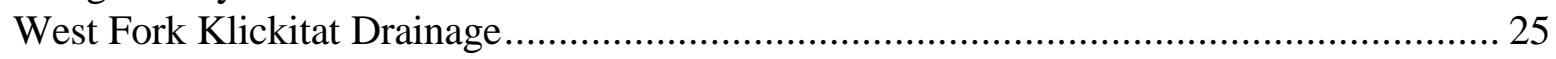

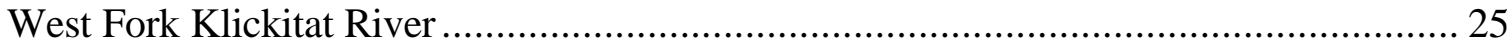

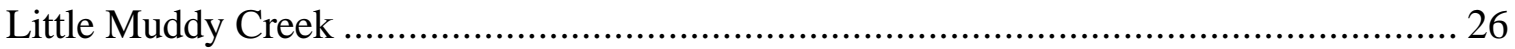

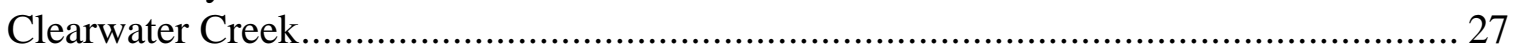

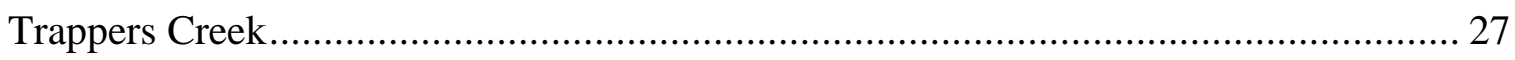

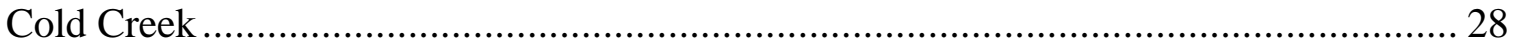

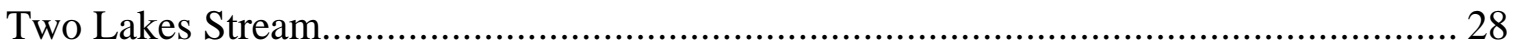

Unnamed Tributaries to Fish Lake Stream .............................................................. 29

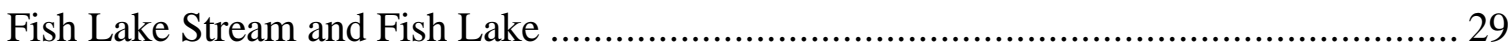

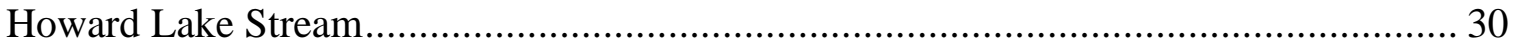

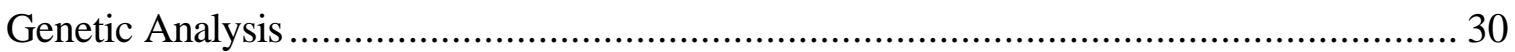

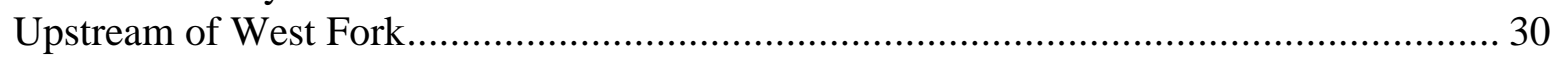

Klickitat River Mainstem (below Castile Falls) …………............................................... 31

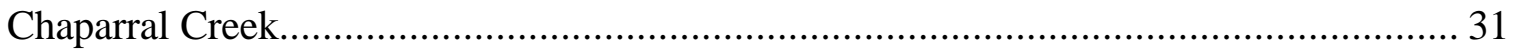

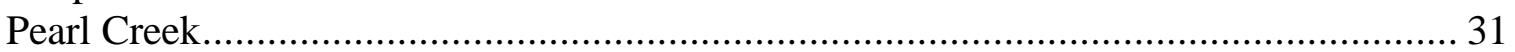

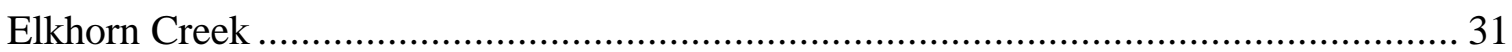




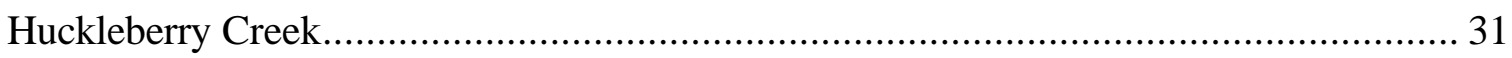

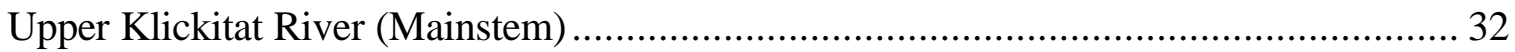

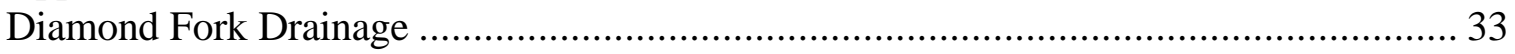

Piscoe Creek............................................................................................... 34

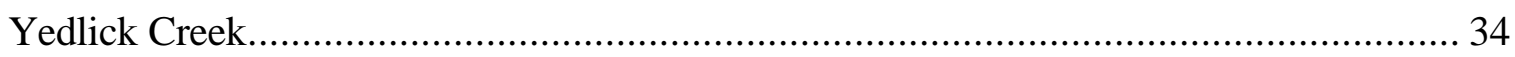

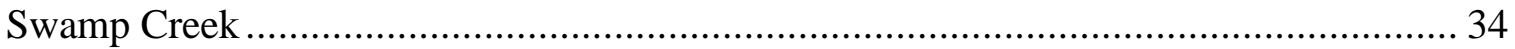

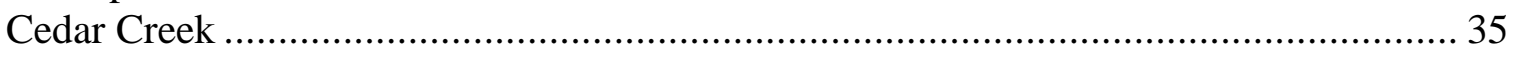

Eastside Streams Near Lower Boundary of Yakama Indian Reservation ......................... 35

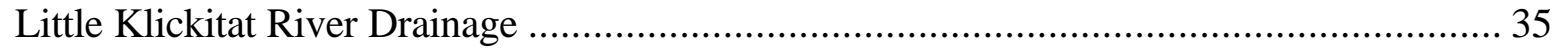

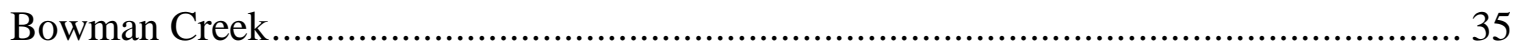

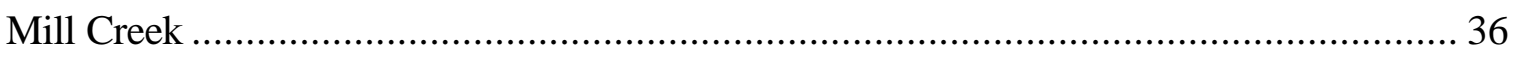

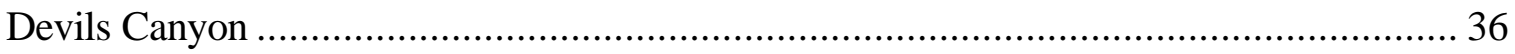

West Prong Little Klickitat River .............................................................. 36

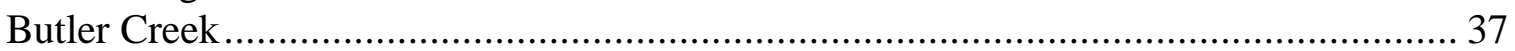

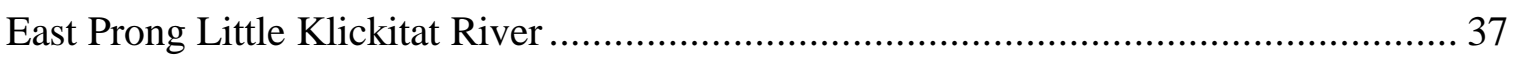

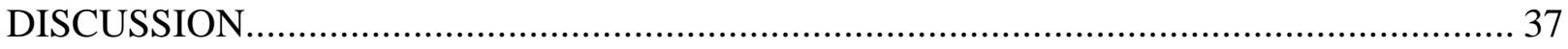

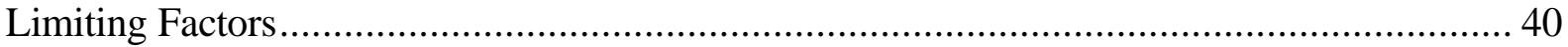

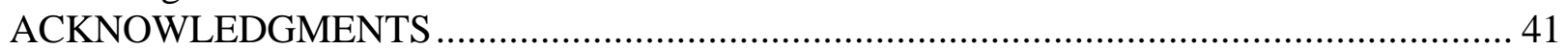

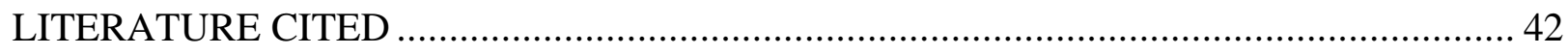

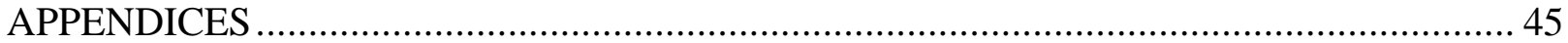




\begin{abstract}
$\underline{\text { ABSTRACT }}$
We utilized night snorkeling and single pass electroshocking to determine the presence or absence of bull trout Salvelinus confluentus in 26 stream reaches $(3,415 \mathrm{~m})$ in the White Salmon basin and in 71 stream reaches $(9,005 \mathrm{~m})$ in the Klickitat River basin during summer and fall 2001. We did not find any bull trout in the White Salmon River basin. In the Klickitat River basin, bull trout were found only in the West Fork Klickitat River drainage. We found bull trout in two streams not previously reported: Two Lakes Stream and an unnamed tributary to Fish Lake Stream (WRIA code number 30-0550). We attempted to capture downstream migrant bull trout in the West Fork Klickitat River by fishing a 1.5-m rotary screw trap at RM 4.3 from July 23 through October 17. Although we caught other salmonids, no bull trout were captured. The greatest limiting factor for bull trout in the West Fork Klickitat River is likely the small amount of available habitat resulting in a low total abundance, and the isolation of the population. Many of the streams are fragmented by natural falls, which are partial or complete barriers to upstream fish movement. To date, we have not been able to confirm that the occasional bull trout observed in the mainstem Klickitat River are migrating upstream into the West Fork Klickitat River.
\end{abstract}

\title{
INTRODUCTION
}

Populations of bull trout Salvelinus confluentus previously ranged over much of the western states and western Canada. Bull trout were widely distributed in Washington, Oregon, Montana, Idaho, Nevada, and California, and in British Columbia, the Yukon Territory, and Alberta in Canada (Buchanan, et al. 1997). Bull trout numbers have been impacted by habitat degradation, passage barriers, harvest pressure, and interactions with introduced species. Many bull trout populations are declining or have disappeared. Past and current efforts to assess, protect, and restore existing bull trout populations have been limited by a lack of basic information on ecology, life history and genetics of bull trout (Rieman and McIntyre 1993; Kostow 1995; Rieman and McIntyre 1995; Buchanan et al. 1997; Spruell and Allendorf 1997: Dunham and Rieman 1999).

Limited information exists on bull trout in the Columbia River Gorge, Washington (Wind, Little White Salmon, White Salmon, and Klickitat river basins). Byrne et al. (2001) initiated studies to determine the presence/absence of bull trout in the Washington tributaries of the Columbia River Gorge during summer and fall 2000. Streams were surveyed in the Wind, Little White Salmon, White Salmon, and Klickitat river basins primarily using night and day snorkeling, and to a lesser extent, backpack electroshocking. Byrne et al. (2001) essentially eliminated the Wind and Little White Salmon basins as having bull trout.

Bull trout were historically present in the White Salmon River. Two bull trout recoveries were reported by Washington Department of Fish and Wildlife (WDFW) biologists in the White Salmon River basin above Condit Dam in Northwestern Lake (WDFW 1998; Figure 1). A 273 $\mathrm{mm}$ bull trout was captured in a gill net set in the spring of 1986, while a second fish, about 305 $\mathrm{mm}$, was checked in the opening day creel census in April 1989. In addition, sport anglers downstream from Condit Dam have reported two sightings in recent years. Byrne et al. (2001) 
snorkeled 22,550 $\mathrm{m}$ of stream in the White Salmon River basin during 2000: 6,050 $\mathrm{m}$ at night and $16,500 \mathrm{~m}$ during the day. They also electroshocked a section of Ninefoot Creek and the upper White Salmon River. No bull trout were observed in the basin during sampling conducted in 2000 .

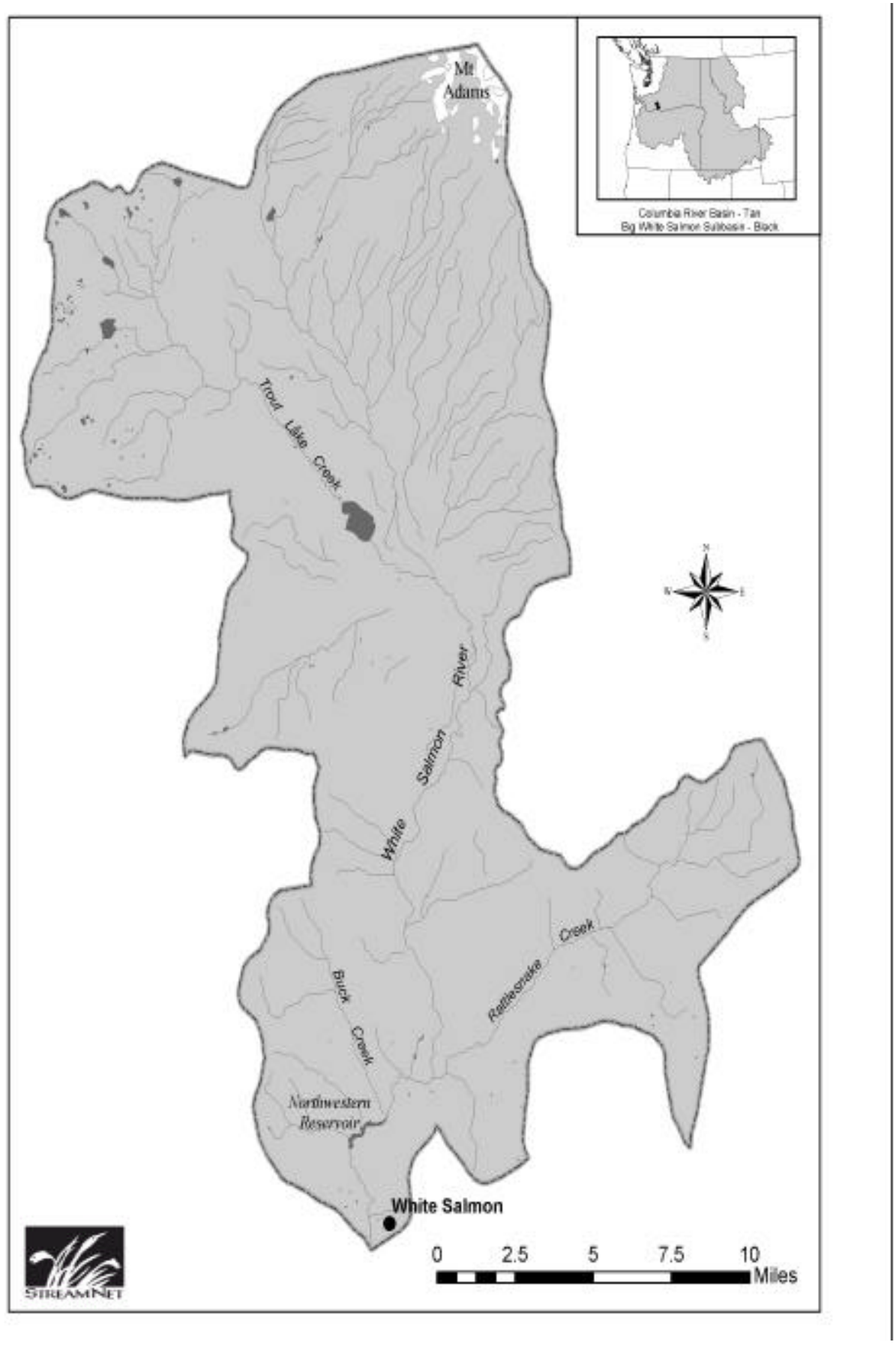

Figure 1. Map of the White Salmon River basin (map courtesy of Stream Net). 
Bull trout were also historically present in the Klickitat River basin. Four bull trout up to $254 \mathrm{~mm}$ in length were reported during snorkel surveys in the mainstem Klickitat River between the West Fork Klickitat River [River Mile (RM) 63.1] and Castile Falls (RM 64) in 1990 (Figure 2), and 23 bull trout (76 to $178 \mathrm{~mm}$ in length) were observed during electroshocking surveys in Trappers Creek in 1995 (Bill Sharp, Yakama Nation, Toppenish, Washington, personal communication; Figure 3). In the early 1990's, a $360 \mathrm{~mm}$ bull trout was caught by angling near the town of Klickitat. Bull trout have also been captured in the Columbia River at the mouth of the Klickitat River. In 1998, tribal northern pikeminnow Ptychocheilus oregonensis gillnetters reported capturing two bull trout at the mouth of the Klickitat. In May 2000, an anecdotal bull trout recovery and release at this area was reported to a Northern Pikeminnow Sport-Reward Registration Station.

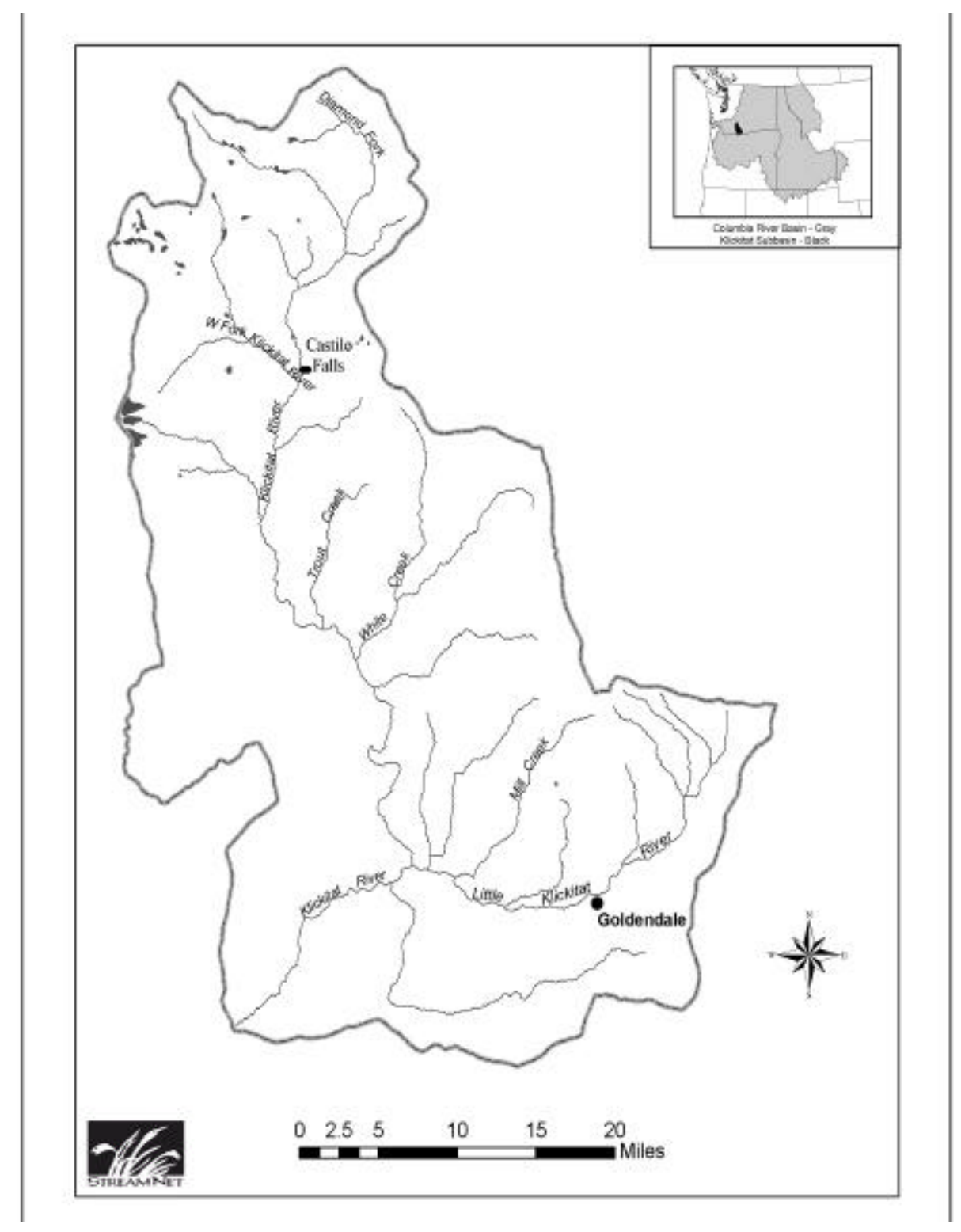

Figure 2. Map of the Klickitat River basin (map courtesy of Stream Net). 
Byrne et al. (2001) snorkeled a total of 4,108 $\mathrm{m}$ in the Klickitat River basin: 3,793 $\mathrm{m}$ at night and $315 \mathrm{~m}$ during the day, in the following tributaries in the Klickitat River basin during 2000: Bird Creek, Dry Creek, Clearwater Creek, Trappers Creek, Little Muddy Creek, Fish Lake Stream, Cunningham Creek, McCreedy Creek, and Diamond Fork. They also checked the West Fork Klickitat by snorkeling at night immediately above the falls near the confluence with Fish Lake Stream, and electroshocked Trappers, Clearwater, McCreedy and Piscoe creeks. Bull trout were observed in Trappers, Clearwater, and Little Muddy creeks, and a single specimen in the West Fork Klickitat River just below the confluence of Little Muddy Creek and Fish Lake Stream.

The work conducted in 2001 focused surveys on the areas in the White Salmon and Klickitat river basins that had not been previously examined. The primary goal of our efforts in 2001 was to complete a preliminary assessment of which streams supported bull trout in most parts of the Klickitat River basin within the Yakama Indian Reservation.

\section{STUDY AREA}

\section{WHITE SALMON RIVER BASIN}

The White Salmon River originates on the south side of Mount Adams and flows south 49 miles before entering Bonneville Reservoir in Underwood, Washington at River Mile (RM) 167 (Figure 1). The White Salmon River drains 386 square miles of Skamania, Klickitat, and Yakima counties. The river is fed by the White Salmon and Avalanche glaciers, which lie above 7,000 feet on Mount Adams. Topography ranges from the steep flanks of Mount Adams to gentle slopes near Trout Lake. Elevation of the drainage ranges from the peak of Mount Adams at 12,276 feet to its mouth at the Columbia River at about 100 feet above sea level.

The upper White Salmon River watershed extends from the headwaters on Mount Adams to the White Salmon River confluence with Trout Lake Creek near the town of Trout Lake (Figure 3). The mainstem of the White Salmon River in this upper reach is approximately 23 miles long. Ninefoot, Green Canyon, and Trout Lake creeks are principle tributaries to the upper White Salmon River that enter the mainstem from the west. Several smaller creeks drain from the west to Trout Lake Creek: Meadow, Mosquito, Cultus, Little Goose and Smokey (this creek actually is a tributary of Little Goose Creek).

Most of the principle tributaries to the upper White Salmon River drain the south slopes of Mount Adams and enter from the northeast, including Cascade, Salt, Wicky, Morrison, Buck, Gotchen, and Hole-in-the-Ground creeks. Glacial melt sustains relatively high summer and spring flows, notably in Cascade Creek and the mainstem. Glacial melt causes turbidity, especially in Cascade Creek and the White Salmon River below the confluence with Cascade Creek. Upstream of Cascade Creek are at least eight unnamed tributaries that appear to be spring fed and are large enough to support fish. 


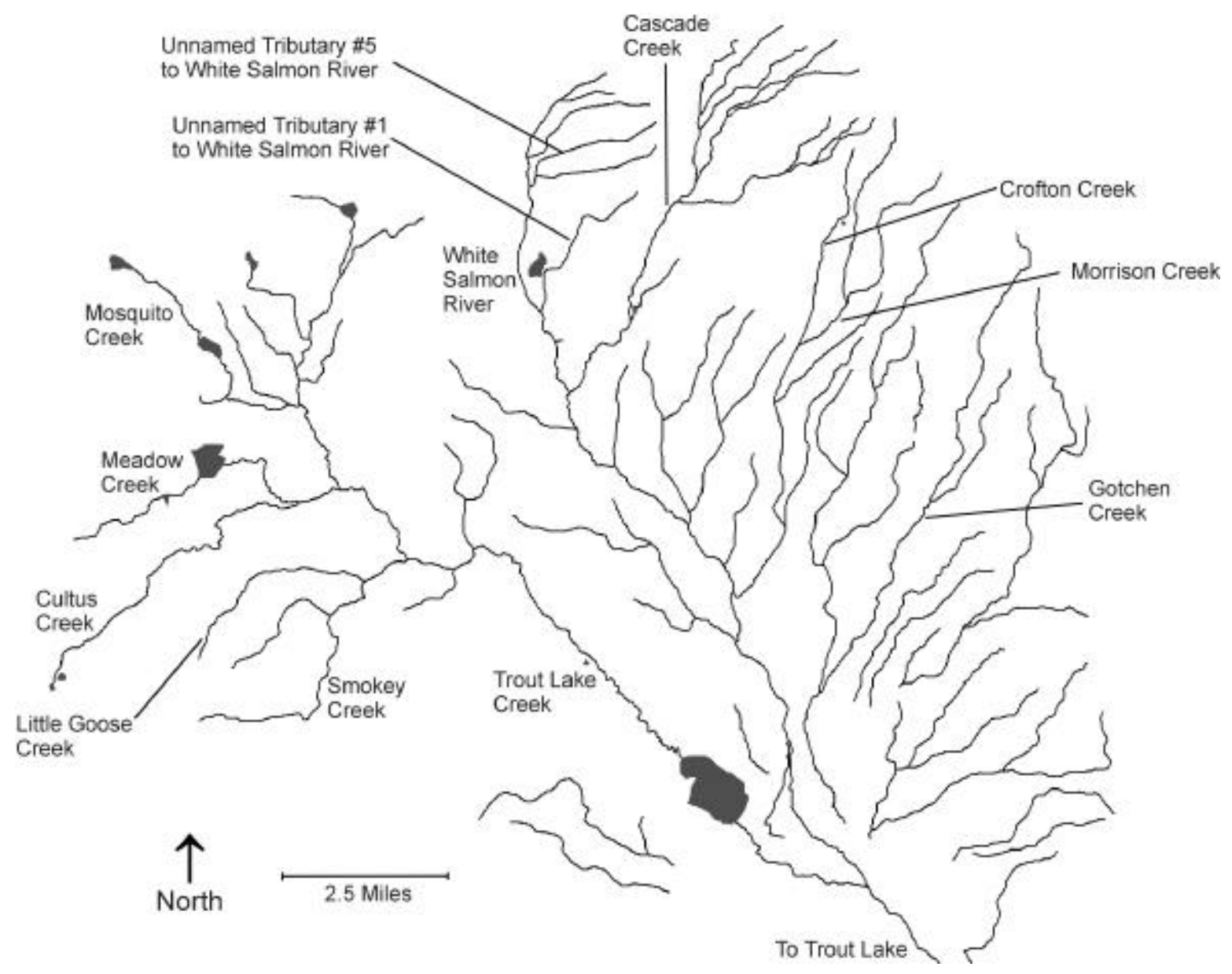

Figure 3. Map of the upper White Salmon River basin (map courtesy of Stream Net).

The lower White Salmon River drainage extends 26 miles from the confluence with Trout Lake Creek to where the river enters Bonneville Reservoir. Principle tributaries in this lower reach are Spring Creek (RM 6.6) from the west and Rattlesnake Creek (RM 7.5) from the east (Figure 4). Condit Dam, located at RM 3.3, creates Northwestern Lake. Buck Creek and Mill Creek enter the lake from the west and Cave Creek meanders from the hills southwest of the town of Trout Lake and enters the mainstem in the valley near Trout Lake. Lost Creek is west southwest of Trout Lake and goes subsurface before reaching the White Salmon River. 


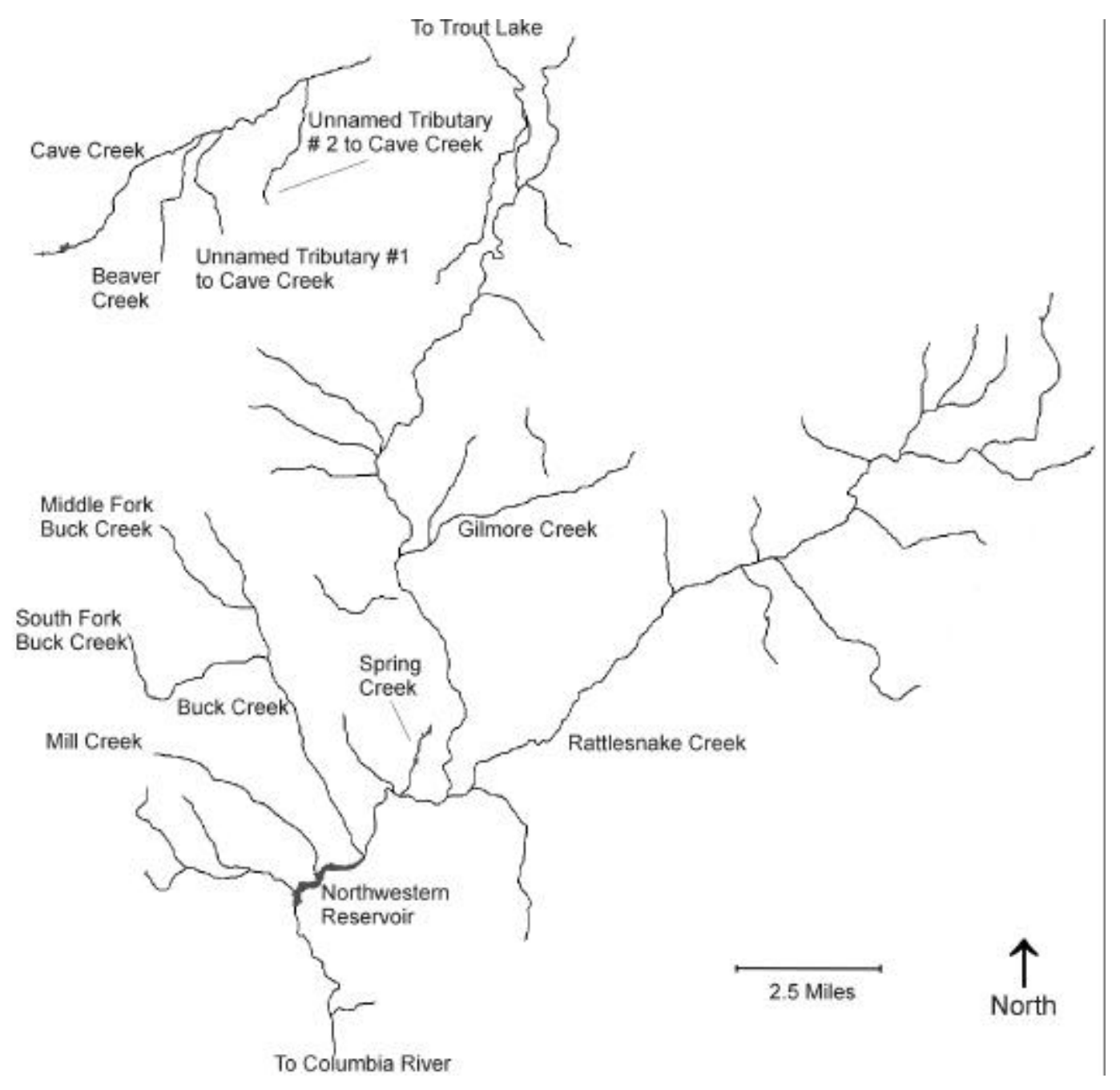

Figure 4. Map of the lower White Salmon River basin (map courtesy of Stream Net).

\section{KLICKITAT RIVER BASIN}

The Klickitat River basin is located on the east slope of the Cascade Range and drains 1,350 square miles in Klickitat and Yakima counties (Figure 2). The Klickitat River is one of the longest undammed rivers in the northwest, flowing nearly 96 miles south from its source near Goat Rocks to where it enters the Columbia River. The topography in the watershed ranges from the rugged flanks of Mount Adams and deep canyons to flat lands and gentle slopes south of the mountain. Elevations range from 12,276 feet at the summit of Mount Adams to about 100 feet where the Klickitat River enters the Columbia River. Extensive basalt strata dominate the geology of the watershed. The erosion-resistant nature of some of these strata has resulted in the creation of deep (700 to 1,500 feet), steep-walled canyons and has severely restricted alluvial floodplain development over most of the watershed. Many of the cascades and waterfalls are due 
to local variations in erosion resistance of these flows (Northwest Power Planning Council 2000). Castile Falls, and falls on the West Fork Klickitat River, Two Lakes Stream, and Huckleberry Creek are likely examples of falls created by erosion resistant flows.

Principle tributaries that enter the Klickitat River from the west are Outlet Creek (RM 39.7), Big Muddy Creek (RM 53.8), the West Fork Klickitat River (RM 63.1) and McCreedy Creek (RM 70.7; Figures 5 and 6). The West Fork Klickitat River drainage is extensive and important with regards to bull trout (Figure 3). Little Muddy Creek joins Fish Lake Stream to form the West Fork Klickitat River at RM 4.5. Trappers, Crawford, and Clearwater creeks are tributaries of Little Muddy Creek. The outlet stream from Howard Lake enters Fish Lake and is the source of Fish Lake Stream. Two Lakes Stream, Cold Creek, and several unnamed creeks are tributaries of Fish Lake Stream. The West Fork Klickitat River drainage contributes significantly to the mainstem, providing three times as much water per square mile as does the rest of the Klickitat River drainage above the West Fork Klickitat River (Cline, 1976). Base flows of late summer and fall are sustained by the West Fork Klickitat River through ground-water discharge and water released from storage in glaciers (Cline, 1976).

Castile Falls on the Klickitat River (RM 64.0 to 64.5) is a series of 11 falls having a total elevation drop of approximately 80 feet. Historically, these falls were thought to be a barrier to most species except spring chinook salmon and summer steelhead (see discussion in Northwest Power Planning Council 2000). "Passage improvements" by the Washington Department of Fisheries during the 1960's may have degraded fish passage, such that salmon and steelhead generally are not able to pass the falls. Chaparral Creek (RM 68.1) and Pearl Creek (RM 69.5) enter the mainstem from the west. The Klickitat River veers to the west at about RM 77.0. Many small tributaries, Huckleberry Creek, and Elkhorn Creek contribute to the upper Klickitat River (Figure 7).

Principle tributaries that enter the Klickitat River from the east are the Little Klickitat River (RM 19.8) and Diamond Fork (RM 76.8). The Little Klickitat River originates north of Goldendale in the Simcoe Mountains where many small tributaries contribute to the river: Bowman, Mill, Devils Canyon, West Prong, Butler, and East Prong creeks (Figure 8). Diamond Fork drains a large basin northeast of the mainstem and many small unnamed tributaries contribute to Diamond Fork.

Mount Adams has a distinct influence on both water quantity and water quality in the Klickitat River. The Klickitat, Wilson and Rusk glaciers on the east flank of Mount Adams contribute water and volcanic debris. Volcanic rock, weathering to clay, and glacial action combine to deliver a large volume of fine sediment to the river system through Big Muddy Creek and Little Muddy Creek. The suspended sediment in these streams during the summer causes turbidity in the Klickitat River from the West Fork to the Columbia River 63 miles downstream. 


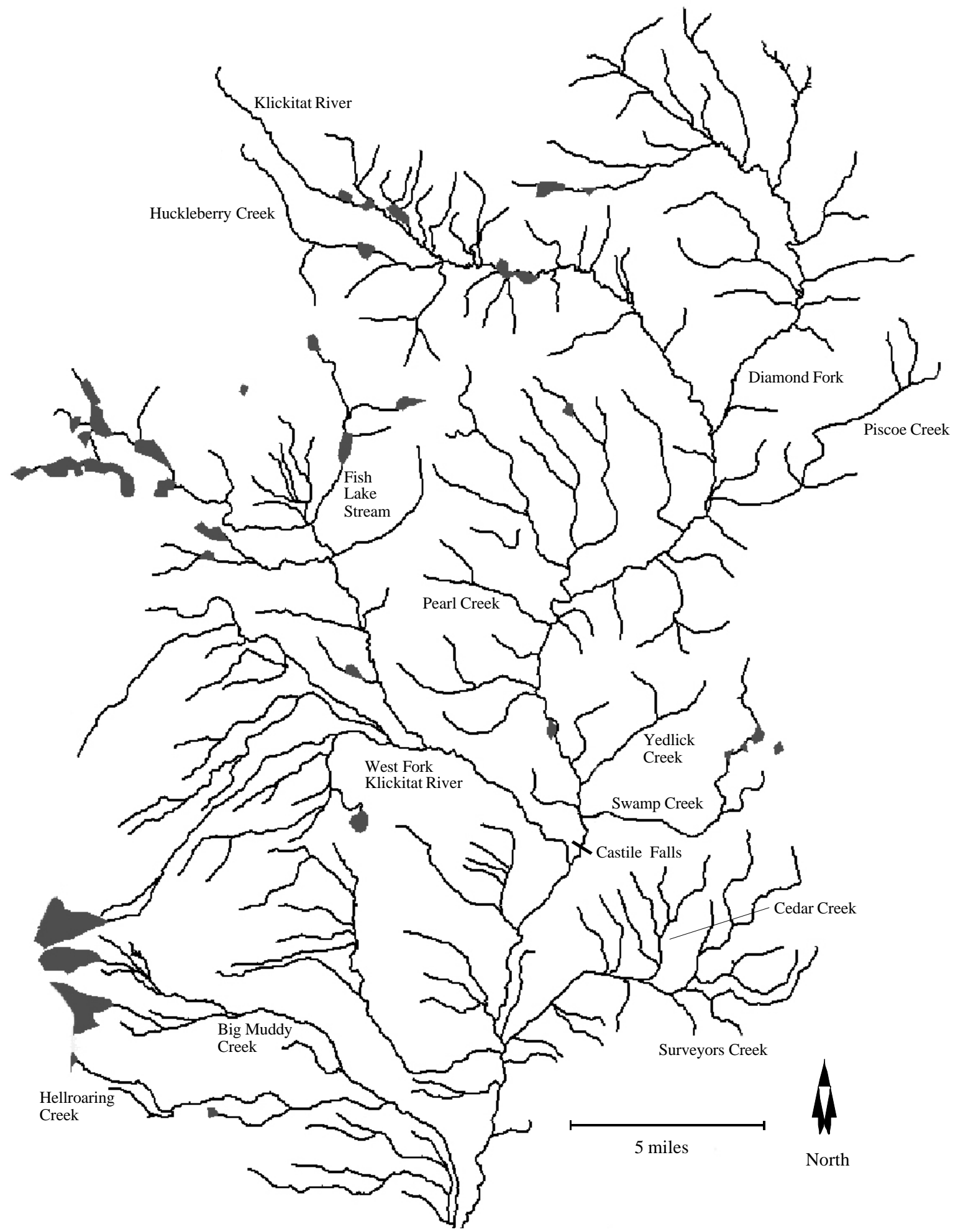

Figure 5. Map of the upper Klickitat River basin upstream of Big Muddy Creek (map courtesy of Stream Net). 


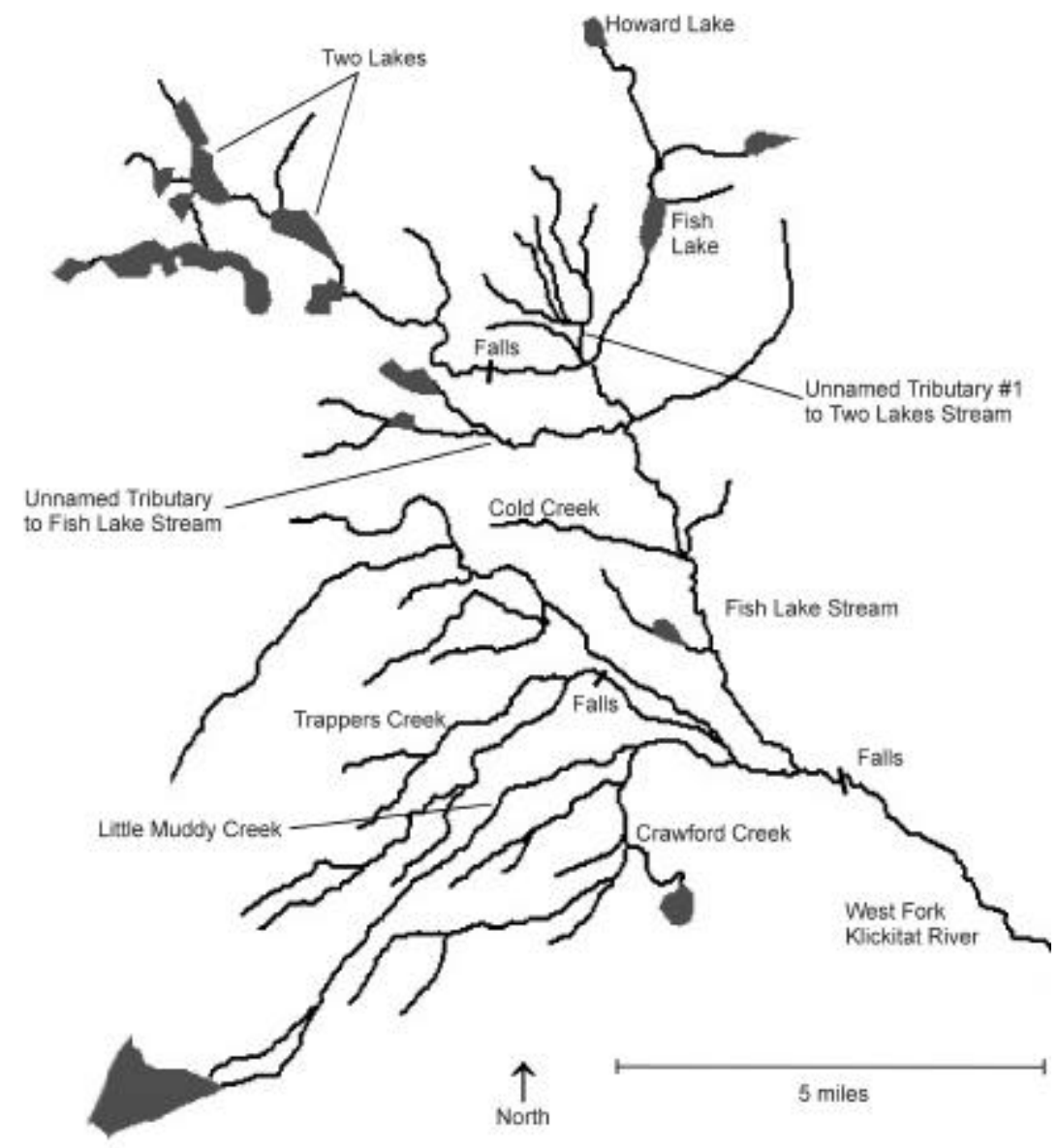

Figure 6. Map of the West Fork Klickitat River basin (map courtesy of Stream Net).

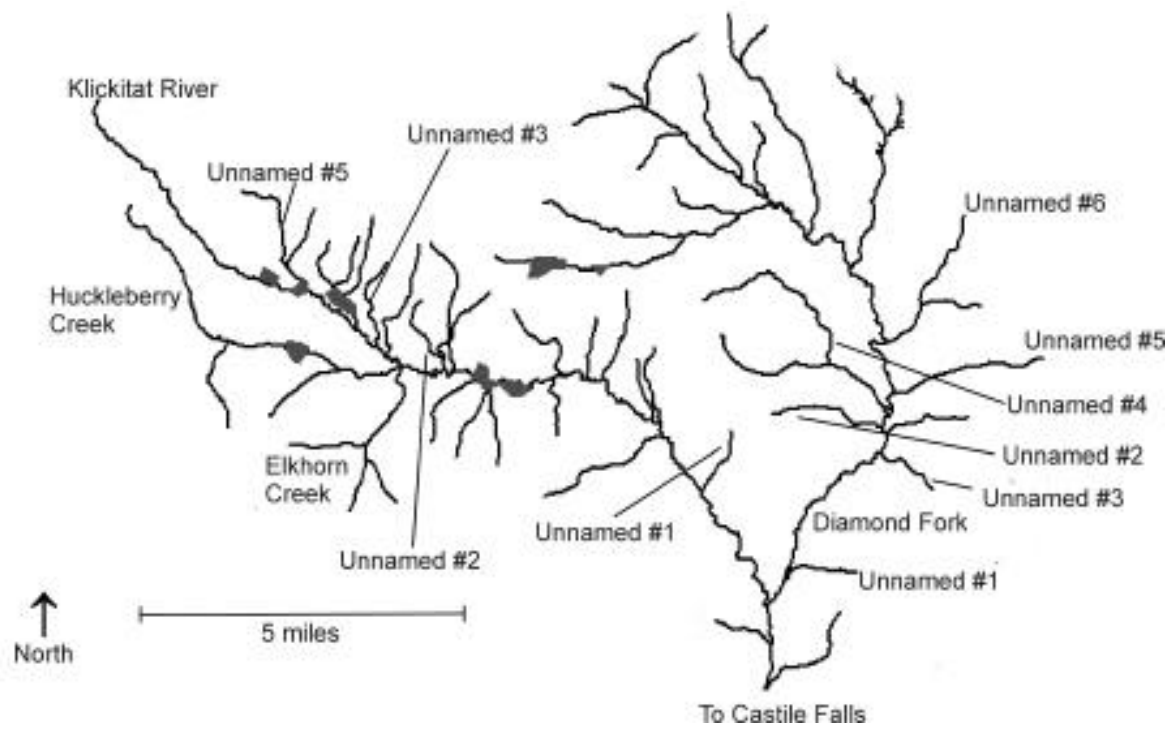

Figure 7. Map of the upper Klickitat River (on the left) and Diamond Fork drainages (on the right; map courtesy of Stream Net). 


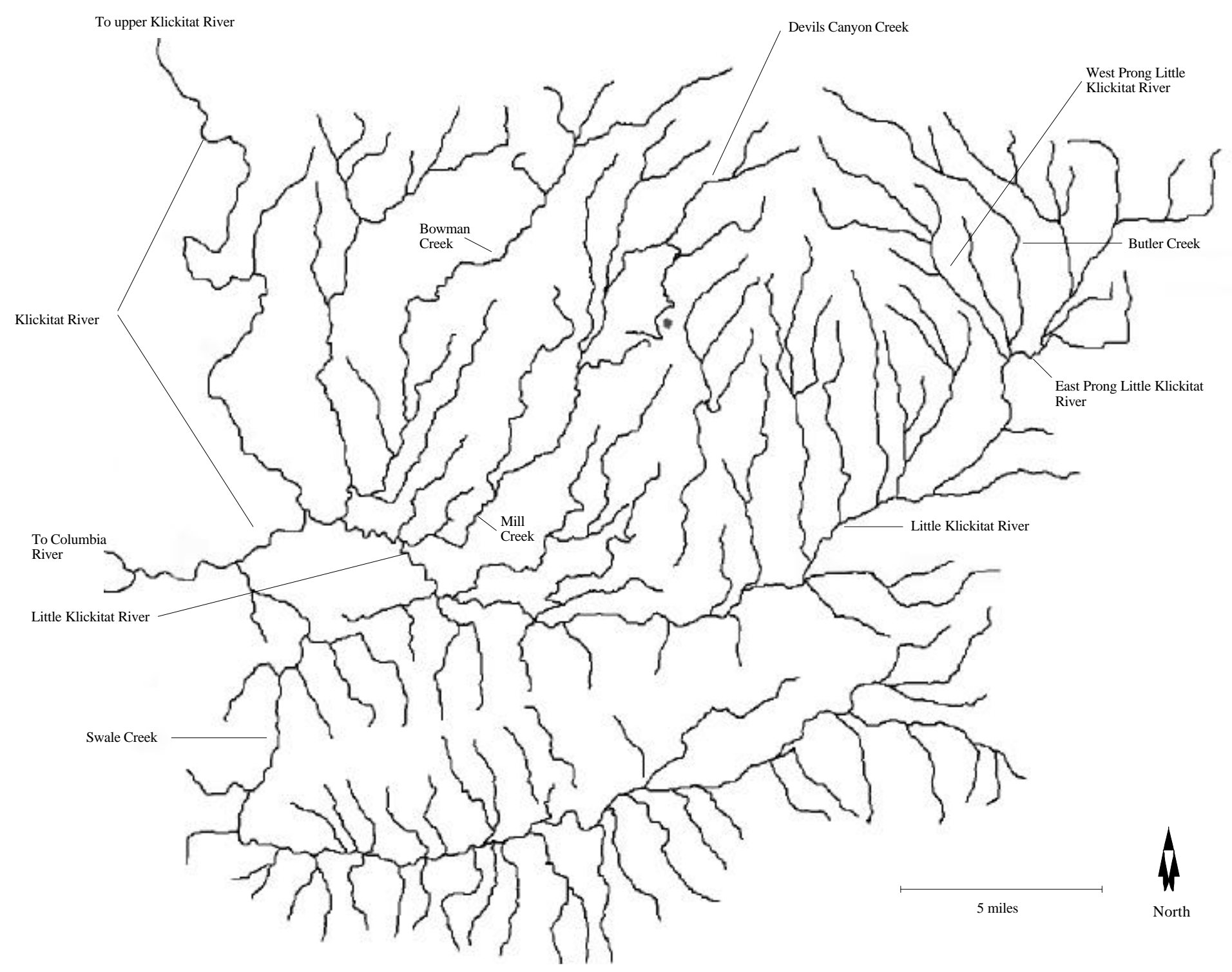

Figure 8. Map of the Little Klickitat River drainage (map courtesy of Stream Net). 


\section{METHODS AND MATERIALS}

Our general approach was to examine each stream in the two watersheds for flow and temperature. Many streams were initially examined near road access or by hiking to determine whether enough water was available to support fish, whether water temperature was appropriate, and whether the creeks needed to be sampled by night snorkeling or electroshocking. These reconnaissance surveys helped to focus our sampling and maximize our effort. Some streams on the Yakama Indian Reservation were not sampled if the Yakama Nation already had sampling programs established for those streams.

Peterson et al. (2002) developed a protocol for determining bull trout presence. The protocol develops probabilities of detection estimates for juvenile migratory and resident bull trout using three sampling methods: day snorkeling, night snorkeling, and backpack electrofishing (3 passes). The protocol recommends a given number of samples required to detect bull trout ( $<200 \mathrm{~mm}$ TL) with $80 \%$ and $95 \%$ probabilities of detection in 50-m and 100-m long sampling units. The protocol also calls for use of block nets at the upper and lower unit boundaries to prevent movement of fish from one unit to the next.

Problems with the draft interim protocol survey methodology were recognized by Byrne et al. (2001). We had similar issues with the protocol and found it difficult to utilize some aspects. The protocol is based upon a beta-binomial probability distribution of detecting fish presence and requires that survey locations be chosen randomly. Due to access, efficiency, and safety issues (deep canyons, extensive log jams, etc.) this was not always possible. Therefore, our sample locations were not chosen randomly. Many of the areas we were investigating had never been sampled for fish. We chose not to use barrier nets in order to cover as much area as possible in a limited amount of time. Use of barrier nets would have added significantly to sampling time and difficulty, and resulted in fewer streams being sampled.

Many small tributaries were sampled during this study using a battery powered SmithRoot (Model 12-B) backpack electroshocker. We followed standard backpack electroshocking protocol for small streams (Reynolds 1996). Our main concern was to capture fish and our settings were set to maximize the capture efficiency until we found fish. We tried to thoroughly work sections using a single pass and considered the size of the stream (flow and width) to determine how best to shock. As with our snorkel surveys, we chose to not use barrier nets. We also chose to use a single pass through each section, rather than three pass electrofishing with barrier nets, in order to sample more streams. Fish collected by electroshocking were retained in a bucket and fork length measured to the nearest millimeter. Fish were returned to the stream after they recovered. Dace Rhinichthys spp., sculpin Cottus spp., salamanders, tailed frogs Ascaphus truei, and other unidentified tadpoles were counted, but usually were not measured. Salamanders were not keyed out to species, except that all salamanders larger than $200 \mathrm{~mm}$ were Dicamptodon spp. Total distance of each creek shocked was visually estimated.

Snorkel surveys were done at night after habitat data was collected during the day. We followed the methodology for snorkel surveys and habitat data collection as described by Byrne et 
al. (2001). A Suunto PM-5/360 PC Clinometer was used for determining the gradient. USIA dry suits and small compact PC Lite underwater flashlights were used for the snorkel surveys. These lights were more functional than larger, bulky flashlights, which were difficult to handle in fast water.

All salmonids were counted during snorkel surveys. Rainbow trout/steelhead Oncorhynchus mykiss, chinook salmon O. tshawytscha, coho salmon $O$. kisutch, brook trout Salvelinus fontinalis, mountain whitefish Prosopium williamsoni, and bull trout were seen during the surveys. The size of each fish was estimated as greater than or less than $150 \mathrm{~mm}$ total length (TL). Because it is difficult to distinguish juvenile rainbow trout from steelhead, we grouped them together as $O$. mykiss, or rainbow trout in the text. Dace, sculpin, tailed frogs, and other unidentified tadpoles were counted.

A 1.5-m rotary screw trap was fished in the West Fork Klickitat River at RM 4.3 from July 23 through October 17. The trap was usually set on Mondays and pulled on Wednesday or Thursday. Occasionally, when other sampling conflicted with checking the trap, it was not fished, or was fished less time. Fish captured in the screw trap were measured for fork length to the nearest millimeter and released downstream of the trap.

Fish Lake was sampled on October 15 using three experimental, monofilament, gillnets placed at various locations around the lake. Each net was 18.2-m long and 1.8-m deep, with 4.6$\mathrm{m}$ panels of 38, 51, 64 and $76 \mathrm{~mm}$ stretched mesh net. Each net was fished twice during the day for a period of 1.5-2 hours per set. Fish were measured for fork length to the nearest millimeter and most were released in good condition following capture. Six mortalities were retained by tribal personnel for disposition.

Tissue samples for mitochondrial DNA analysis of genetic population structure were obtained from bull trout that were collected during the study. Fin clips ( $4 \mathrm{x} 4 \mathrm{~mm}$ ) were taken from the caudal fin and immediately placed in ethanol. Late in the study, we realized that we should have been collecting tissue samples from other species also, even though the project was not funded for analyzing them. Tissue samples were taken for DNA analysis from O. mykiss collected in several tributaries of the Little Klickitat River. These samples are archived at the WDFW lab in Olympia, but no analysis is currently planned.

\section{$\underline{\text { RESULTS }}$}

We sampled 3,415 $\mathrm{m}$ in 26 stream reaches in the White Salmon basin (Table 1) and 9,005 $m$ in 71 stream reaches and Fish Lake in the Klickitat River basin (Table 2) during summer and fall 2001. Specific electroshock, snorkel, and habitat data are presented in Appendices 1-3. 
Table 1. Locations examined for bull trout in the White Salmon River drainage during 2001.

\begin{tabular}{|c|c|c|c|c|c|}
\hline Site & Date & $\begin{array}{c}\text { Temperature } \\
{ }^{\circ} \mathrm{C} \\
\end{array}$ & $\begin{array}{c}\text { Sampling } \\
\text { Technique }^{\mathrm{a}} \\
\end{array}$ & $\begin{array}{c}\text { Distance } \\
\text { Sampled (m) }\end{array}$ & Species Found ${ }^{\mathrm{c}}$ \\
\hline \multicolumn{6}{|l|}{ Westside Streams (Downstream of Trout Lake) } \\
\hline Mill Creek & $9 / 20$ & 12.0 & $\mathrm{E}$ & 150 & $\mathrm{Rb}$ \\
\hline Middle Fork Buck Creek & $6 / 26$ & 8.3 & $\mathrm{~S}$ & 100 & None \\
\hline Buck Creek (lower) & $6 / 26$ & 12.2 & $\mathrm{~S}$ & 100 & $\mathrm{Rb}$ \\
\hline Buck Creek (dam) & $6 / 26$ & 10.3 & $\mathrm{~S}$ & 200 & $\mathrm{Rb}$ \\
\hline Spring Creek & $8 / 13$ & 11.7 & $\mathrm{~S}$ & 300 & $\mathrm{Rb}, \mathrm{Bk}$ \\
\hline Beaver Creek & $8 / 29$ & 13.3 & $\mathrm{E}$ & 50 & $\mathrm{Bk}$ \\
\hline Unnamed tributary of Beaver Creek \#1 & $8 / 29$ & 5.8 & $\mathrm{E}$ & 100 & $\mathrm{Bk}$ \\
\hline Unnamed tributary of Beaver Creek \#2 (lower) & $9 / 21$ & 8.0 & $\mathrm{E}$ & 50 & $\mathrm{Bk}$ \\
\hline Unnamed tributary of Beaver Creek \#2 (upper) & $8 / 29$ & 7.2 & $\mathrm{E}$ & 100 & none \\
\hline \multicolumn{6}{|l|}{ Eastside Streams (Downstream of Trout Lake) } \\
\hline Crofton Creek & $9 / 20$ & 5.0 & $\mathrm{E}$ & 200 & None \\
\hline Elmer Canyon & $10 / 30$ & 7.1 & $\mathrm{E}$ & 50 & None \\
\hline \multicolumn{6}{|l|}{ Southside Streams (Upstream of Trout Lake) } \\
\hline Lost Creek $^{\mathrm{d}}$ & $7 / 2$ & 5.0 & $\mathrm{~S}$ & 200 & $\mathrm{Rb}, \mathrm{Bk}$ \\
\hline Smokey Creek & $7 / 9$ & 12.0 & $\mathrm{~S}$ & 100 & Bk \\
\hline Cultus Creek (upper) & $7 / 11$ & 10.0 & $\mathrm{~S}$ & 100 & None \\
\hline Cultus Creek (lower) & $7 / 9$ & 13.3 & $\mathrm{~S}$ & 200 & $\mathrm{Rb}, \mathrm{Bk}$ \\
\hline Little Goose Creek & $7 / 2$ & 6.9 & $\mathrm{~S}$ & 100 & $\mathrm{Bk}$ \\
\hline
\end{tabular}


Table 1. Continued.

\begin{tabular}{|c|c|c|c|c|c|}
\hline Site & Date & $\begin{array}{c}\text { Temperature } \\
{ }^{\circ} \mathrm{C}\end{array}$ & $\begin{array}{c}\text { Sampling } \\
\text { Technique }^{\mathrm{a}}\end{array}$ & $\begin{array}{c}\text { Distance } \\
\text { Sampled }(\mathrm{m})^{\mathrm{b}}\end{array}$ & Species Found $^{\mathrm{C}}$ \\
\hline Meadow Creek (upper) & $6 / 27$ & 7.2 & $\mathrm{~S}$ & 100 & $\mathrm{Rb}$ \\
\hline Meadow Creek (lower) & $6 / 27$ & 10.5 & $\mathrm{~S}$ & 200 & $\mathrm{Rb}$ \\
\hline Mosquito Creek (upper) & $7 / 10$ & 7.8 & $\mathrm{~S}$ & 100 & None \\
\hline Mosquito Creek (lower) & $7 / 10$ & 6.7 & $\mathrm{~S}$ & 100 & $\mathrm{Bk}$ \\
\hline \multicolumn{6}{|l|}{ Northside Streams (Upstream of Trout Lake) } \\
\hline Unnamed tributary of White Salmon River \#1 & $10 / 23$ & 2.8 & $\mathrm{E}$ & 200 & $\mathrm{Rb}$ \\
\hline Unnamed tributary of White Salmon River \#2 & $10 / 24$ & 3.3 & $\mathrm{E}$ & 150 & $\mathrm{Rb}$ \\
\hline Unnamed tributary of White Salmon River \#3 & $10 / 23$ & 2.8 & $\mathrm{E}$ & 100 & $\mathrm{Rb}$ \\
\hline Unnamed tributary of White Salmon River \#4 & $10 / 24$ & 3.3 & $\mathrm{E}$ & 75 & $\mathrm{Rb}$ \\
\hline Unnamed tributary of White Salmon River \#5 & $10 / 23$ & 2.8 & $\mathrm{E}$ & 140 & $\mathrm{Rb}$ \\
\hline Unnamed tributary of White Salmon River \#6 & $10 / 24$ & 2.2 & $\mathrm{E}$ & 50 & $\mathrm{Rb}$ \\
\hline
\end{tabular}

a. $\mathrm{S}=$ night snorkel, $\mathrm{E}=$ electroshock. Block nets were not used for either method.

b. Distances were rough visual estimates for electroshocking. Transects snorkeled were measured.

c. $\mathrm{Rb}=$ rainbow trout, $\mathrm{Bk}=$ brook trout, $\mathrm{Bu}=$ bull trout, $\mathrm{Ch}=$ chinook salmon, $\mathrm{Co}=$ coho salmon, $\mathrm{Sc}=$ sculpin species, $\mathrm{Da}=$ dace species.

d. Lost Creek becomes subterranean before reaching any major river. However, an irrigation ditch brings water from Lost Creek to Coyote Creek, a tributary to the White Salmon River. 
Table 2. Locations examined for bull trout in the Klickitat River drainage during 2001.

\begin{tabular}{|c|c|c|c|c|c|}
\hline Site & Date & $\begin{array}{c}\text { Temperature } \\
{ }^{\circ} \mathrm{C} \\
\end{array}$ & $\begin{array}{c}\text { Sampling } \\
\text { Technique }^{\mathrm{a}} \\
\end{array}$ & $\begin{array}{c}\text { Distance } \\
\text { Sampled }(\mathrm{m})^{\mathrm{b}}\end{array}$ & Species Found $^{\mathrm{c}}$ \\
\hline \multicolumn{6}{|c|}{ Westside Tributaries Below West Fork } \\
\hline Outlet Creek & $10 / 9$ & 8.3 & $\mathrm{~S}$ & 200 & $\mathrm{Om}, \mathrm{Bk}, \mathrm{Co}, \mathrm{Sc}$ \\
\hline Big Muddy Creek & $10 / 10$ & 4.5 & $\mathrm{E}$ & 150 & None \\
\hline West Fork Klickitat R at RM 0.2 & $7 / 17$ & 9.2 & $\mathrm{~S}$ & 100 & Om, Bk, Ch, Wf, Sc \\
\hline West Fork Klickitat R at RM 2.2 & $7 / 24$ & 10.0 & $\mathrm{~S}$ & 100 & $\mathrm{Om}, \mathrm{Bk}, \mathrm{Bu}$ \\
\hline West Fork Klickitat R at RM 4.3 & $7 / 16$ & 7.2 & $\mathrm{~S}$ & 100 & $\mathrm{Om}, \mathrm{Bk}, \mathrm{Bu}$ \\
\hline \multicolumn{6}{|l|}{ Little Muddy Creek } \\
\hline Above Trappers Creek & $7 / 30$ & 8.5 & $\mathrm{E}$ & 100 & $\mathrm{Bu}$ \\
\hline Near Crawford Creek & $7 / 25$ & & $\mathrm{E}$ & 100 & None \\
\hline \multicolumn{6}{|l|}{ Clearwater Creek } \\
\hline Between Falls \#1 and \#2 & $7 / 30$ & 7.0 & $\mathrm{~S}$ and $\mathrm{E}$ & 100 and 50 & None \\
\hline \multicolumn{6}{|l|}{ West Fork Drainage } \\
\hline \multicolumn{6}{|l|}{ Trappers Creek } \\
\hline Below Falls & $7 / 23$ & 9.5 & $\mathrm{~S}$ & 100 & $\mathrm{Bu}$ \\
\hline Above Falls & $7 / 23$ & 9.5 & $\mathrm{~S}$ & 100 & None \\
\hline Above Adams Lake Road & $7 / 16$ & 5.6 & $\mathrm{~S}$ & 100 & None \\
\hline Below Adams Lake Road & $7 / 16$ & 5.6 & $\mathrm{~S}$ & 100 & None \\
\hline Cold Creek & $10 / 17$ & 4.2 & $\mathrm{E}$ & 100 & $\mathrm{Om}, \mathrm{Bk}$ \\
\hline \multicolumn{6}{|l|}{ Two Lakes Stream } \\
\hline Below Falls & $9 / 26$ & 5.2 & $\mathrm{~S}$ & 200 & $\mathrm{Om}, \mathrm{Bk}, \mathrm{Bu}$ \\
\hline Above Falls & $9 / 25$ & 9.0 & $\mathrm{E}$ & 100 & Om, Bk \\
\hline
\end{tabular}


Table 2. Continued.

\begin{tabular}{|c|c|c|c|c|c|}
\hline Site & Date & $\begin{array}{c}\text { Temperature } \\
{ }^{\circ} \mathrm{C}\end{array}$ & $\begin{array}{c}\text { Sampling } \\
\text { Technique }^{\mathrm{a}} \\
\end{array}$ & $\begin{array}{c}\text { Distance } \\
\text { Sampled }(\mathrm{m})^{\mathrm{b}}\end{array}$ & Species Found ${ }^{\mathrm{c}}$ \\
\hline \multicolumn{6}{|l|}{ Tributaries to Two Lakes Stream } \\
\hline Unnamed tributary \#1 (lower) & $10 / 3$ & 4.5 & $\mathrm{~S}$ and $\mathrm{E}$ & 200 and 150 & Om, Bk \\
\hline Unnamed tributary \#1 (upper) & $10 / 3$ & 4.5 & E & 100 & $\mathrm{Bk}$ \\
\hline Unnamed tributary to unnamed \#1 & $10 / 8$ & 4.0 & $\mathrm{~S}$ & 100 & $\mathrm{Om}, \mathrm{Bk}$ \\
\hline Unnamed tributary \# 2 (above falls) & $9 / 25$ & 4.5 & $\mathrm{E}$ & 100 & $\mathrm{Bk}$ \\
\hline Fish Lake Stream (below lake) & $10 / 2$ & 10.0 & $\mathrm{E}$ & 300 & Om, Bk \\
\hline Unnamed tributary to Fish Lake Stream & $9 / 26$ & 8.5 & $\mathrm{E}$ & 100 & $\mathrm{Om}, \mathrm{Bu}$ \\
\hline Unnamed tributary to Unnamed & $9 / 26$ & 5.6 & $\mathrm{E}$ & 100 & None \\
\hline Fish Lake & $10 / 15$ & 8.2 & $\mathrm{G}$ & --- & $\mathrm{Om}, \mathrm{Bk}$ \\
\hline Howard Lake Stream (eastern fork) & $10 / 1$ & 7.0 & $\mathrm{E}$ & 100 & None \\
\hline Howard Lake Stream (western fork) & $10 / 1$ & 6.7 & $\mathrm{E}$ & 150 & Om, Bk \\
\hline \multicolumn{6}{|l|}{ Upper Klickitat Drainage } \\
\hline Klickitat River (below Castile Falls) & $7 / 17$ & 13.0 & S & 200 & $\mathrm{Om}, \mathrm{Bk}, \mathrm{Ch}, \mathrm{Sc}$ \\
\hline Chaparral Creek & $8 / 28$ & 11.7 & $\mathrm{E}$ & 125 & $\mathrm{Om}$ \\
\hline Pearl Creek & $8 / 28$ & 9.5 & $\mathrm{E}$ & 200 & None \\
\hline Elkhorn Creek & $8 / 1$ & 11.2 & $\mathrm{E}$ & 300 & $\mathrm{Om}, \mathrm{Bk}$ \\
\hline Huckleberry Creek (lower) & $8 / 20$ & 7.8 & $\mathrm{E}$ & 150 & None \\
\hline Huckleberry Creek (upper) & $8 / 7$ & 12.2 & $\mathrm{E}$ & 300 & None \\
\hline Klickitat River at RM 86.7 & $7 / 31$ & 12.9 & S & 300 & $\mathrm{Om}, \mathrm{Bk}, \mathrm{Ch}$ \\
\hline Klickitat River at RM 91.5 & $8 / 21$ & 9.5 & $\mathrm{E}$ & 25 & $\mathrm{Om}$ \\
\hline Klickitat River at RM 91.6 & $8 / 27$ & 9.5 & $\mathrm{E}$ & 350 & Om \\
\hline
\end{tabular}


Table 2. Continued.

\begin{tabular}{|c|c|c|c|c|c|}
\hline Site & Date & $\begin{array}{c}\text { Temperature } \\
{ }^{\circ} \mathrm{C}\end{array}$ & $\begin{array}{c}\text { Sampling } \\
\text { Technique }^{\mathrm{a}} \\
\end{array}$ & $\begin{array}{c}\text { Distance } \\
\text { Sampled }(\mathrm{m})^{\mathrm{b}}\end{array}$ & Species Found \\
\hline Unnamed tributary to Klickitat River \#1, RM 79.9 & $8 / 1$ & ---- & $\mathrm{E}$ & 50 & $\mathrm{Bk}$ \\
\hline Unnamed tributary to Klickitat River \#2, RM 86.55 & $7 / 31$ & 9.8 & $\mathrm{E}$ & 100 & $\mathrm{Om}, \mathrm{Bk}$ \\
\hline Unnamed tributary to Klickitat River \#3, RM 87.95 & $8 / 20$ & 7.2 & $\mathrm{E}$ & 100 & None \\
\hline Unnamed tributary to unnamed \#4, RM 88.4 & $8 / 20$ & 11.1 & $\mathrm{E}$ & 100 & $\mathrm{Om}$ \\
\hline Unnamed tributary to Klickitat River \#5, RM 89.7 & $8 / 21$ & 8.3 & $\mathrm{E}$ & 100 & $\mathrm{Om}$ \\
\hline Unnamed tributary to Klickitat River \#6, RM 91.8 & $8 / 27$ & 6.1 & $\mathrm{E}$ & 80 & $\mathrm{Om}, \mathrm{Bk}$ \\
\hline Piscoe Creek & $8 / 15$ & 15.0 & $\mathrm{E}$ & 100 & Om \\
\hline Yedlick Creek & $8 / 15$ & 15.0 & $\mathrm{E}$ & 100 & Om \\
\hline Swamp Creek & $9 / 26$ & 10.0 & $\mathrm{E}$ & 50 & Om \\
\hline Cedar Creek & $10 / 2$ & 9.8 & $\mathrm{E}$ & 100 & $\mathrm{Om}$ \\
\hline Summit Creek & $10 / 10$ & 4.5 & $\mathrm{E}$ & 100 & $\mathrm{Om}, \mathrm{Bk}$ \\
\hline \multicolumn{6}{|l|}{ Diamond Fork Drainage } \\
\hline Unnamed tributary to Diamond Fork \#1 & $9 / 18$ & 6.8 & $\mathrm{E}$ & 100 & None \\
\hline Unnamed tributary to Diamond Fork \#2 & $9 / 11$ & 10.0 & $\mathrm{E}$ & 180 & Om \\
\hline Unnamed tributary to Diamond Fork \#3, upper & $9 / 12$ & 9.5 & $\mathrm{E}$ & 100 & None \\
\hline Unnamed tributary to Diamond Fork \#3, lower & $9 / 12$ & 9.0 & $\mathrm{E}$ & 140 & None \\
\hline Unnamed tributary to Diamond Fork \#4, lower & $9 / 18$ & 7.2 & $\mathrm{E}$ & 100 & $\mathrm{Om}, \mathrm{Bk}$ \\
\hline Unnamed tributary to Diamond Fork \#4, upper & $9 / 19$ & 6.8 & $\mathrm{E}$ & 100 & $\mathrm{Bk}$ \\
\hline Unnamed tributary to Unnamed \#4, lower & $9 / 18$ & 6.5 & $\mathrm{E}$ & 200 & $\mathrm{Bk}$ \\
\hline Unnamed tributary to Unnamed \#4, upper & $9 / 19$ & 5.0 & $\mathrm{E}$ & 150 & $\mathrm{Bk}$ \\
\hline Unnamed tributary to Diamond Fork \#5 & $9 / 10$ & 10.5 & $\mathrm{E}$ & 260 & $\mathrm{Om}$ \\
\hline Unnamed tributary to Diamond Fork \#6 & $9 / 10$ & 8.5 & $\mathrm{E}$ & 250 & $\mathrm{Om}$ \\
\hline
\end{tabular}


Table 2. Continued.

\begin{tabular}{|c|c|c|c|c|c|}
\hline Site & Date & $\begin{array}{c}\text { Temperature } \\
{ }^{\circ} \mathrm{C}\end{array}$ & $\begin{array}{c}\text { Sampling } \\
\text { Technique }^{\mathrm{a}}\end{array}$ & $\begin{array}{c}\text { Distance } \\
\text { Sampled }(\mathrm{m})^{\mathrm{b}}\end{array}$ & Species Found ${ }^{\mathrm{c}}$ \\
\hline Unnamed tributary to Diamond Fork \#7 & $9 / 18$ & 5.2 & $\mathrm{E}$ & 150 & $\mathrm{Om}, \mathrm{Bk}$ \\
\hline Unnamed tributary to Diamond Fork \#8 & $9 / 18$ & 6.7 & $\mathrm{E}$ & 200 & None \\
\hline Unnamed tributary to Diamond Fork \#9 & $9 / 18$ & 6.4 & $\mathrm{E}$ & 40 & None \\
\hline \multicolumn{6}{|l|}{ Little Klickitat River Tributaries } \\
\hline Bowman Creek (lower) & $10 / 31$ & 6.7 & $\mathrm{E}$ & 100 & Om, Sc, Da \\
\hline Bowman Creek (upper) & $10 / 31$ & 7.5 & $\mathrm{E}$ & 100 & $\mathrm{Om}$ \\
\hline Mill Creek (lower) & $10 / 31$ & 7.2 & $\mathrm{E}$ & 100 & Om \\
\hline Mill Creek (upper) & $11 / 12$ & 4.3 & $\mathrm{E}$ & 100 & $\mathrm{Om}$ \\
\hline Devils Canyon Creek (eastern fork) & $11 / 12$ & 2.5 & $\mathrm{E}$ & 100 & $\mathrm{Om}$ \\
\hline Devils Canyon Creek & $11 / 12$ & 2.5 & $\mathrm{E}$ & 80 & Om \\
\hline West Prong Little Klickitat River (lower) & $11 / 7$ & 0.0 & $\mathrm{E}$ & 100 & $\mathrm{Om}, \mathrm{Sc}$ \\
\hline West Prong Little Klickitat River (upper) & $11 / 7$ & 0.0 & $\mathrm{E}$ & 75 & None \\
\hline Unnamed Tributary & $11 / 7$ & 0.0 & $\mathrm{E}$ & 25 & $\mathrm{Om}$ \\
\hline Butler Creek (lower) & $10 / 29$ & 7.2 & $\mathrm{E}$ & 100 & $\mathrm{Om}$ \\
\hline Butler Creek (middle) & $11 / 5$ & 2.0 & $\mathrm{E}$ & 50 & $\mathrm{Om}$ \\
\hline Butler Creek (upper) & $11 / 6$ & 0.5 & $\mathrm{E}$ & 75 & $\mathrm{Om}$ \\
\hline Butler Creek (upper) & $11 / 6$ & 0.0 & $\mathrm{E}$ & 75 & None \\
\hline East Prong Little Klickitat River & $10 / 29$ & 7.2 & $\mathrm{E}$ & 75 & $\mathrm{Om}$ \\
\hline
\end{tabular}

a. $S=$ night snorkel, $E=$ electroshock (block nets were not used for either method), $G=$ Gill Net.

b. Distances were rough visual estimates for electroshocking. Transects snorkeled were measured.

c. $\mathrm{Om}=$ O. mykiss (rainbow trout and/or juvenile steelhead), $\mathrm{Bk}=$ brook trout, $\mathrm{Bu}=$ bull trout, $\mathrm{Ch}=$ chinook salmon, $\mathrm{Co}=$ coho salmon, $\mathrm{Sc}=$ sculpin species, $\mathrm{Da}=$ dace species. 


\section{WHITE SALMON RIVER BASIN}

We surveyed 26 stream reaches during 2001 that were not sampled in 2000 (Table 1). Many of the streams that we sampled in 2001 were smaller than the larger streams sampled in 2000, especially those west of Trout Lake. No bull trout were found in the White Salmon River basin.

\section{$\underline{\text { Mill Creek }}$}

Mill Creek originates in a deep canyon west of Northwestern Lake and drains to the lake. The creek, which was electroshocked at RM 1.7 on September 20, was 5-6 m wide, low gradient, had moderate flow, and $12.0^{\circ} \mathrm{C}$. Four age classes of $O$. mykiss were captured and they were abundant.

\section{$\underline{\text { Buck Creek }}$}

Buck Creek drains a large canyon complex west of Northwestern Lake and enters the lake just above the "lake bridge." The middle fork was fairly cool and appeared to be a spring fed system suitable for bull trout. Middle Fork Buck Creek was 2-3 m wide, high gradient (12.5\%), had moderate flow, some large wood debris (LWD), and was $8.3^{\circ} \mathrm{C}$ (Table 3). We snorkeled the Middle Fork at RM 0.1 on June 26, but did not observe any fish. We observed tailed frog tadpoles, 1 unidentified tadpole, and 18 Dicamptodon spp. salamanders.

Three hundred meters of Buck Creek were snorkeled on June 26 at a lower site (RM 1.4) and an upper site above the dam (RM 3.9). The creek in these areas was 5-11 m wide, had good flow, a gradient $<4 \%$, some LWD, and was $10.3-12.2^{\circ} \mathrm{C}$. Buck Creek had the third highest density of $O$. mykiss of any of the streams snorkeled in 2001 (Table 3). A few sculpin were seen at the lower site. Dicamptodon spp. salamanders were observed at both locations, while tailed frog tadpoles and unidentified tadpoles were observed only at the upper site. South Fork Buck Creek winds through an essentially roadless basin and was not sampled, but probably should be.

\section{Spring Creek}

Spring Creek enters the mainstem White Salmon River above Northwestern Lake at RM 6.6. Three 100-m transects of Spring Creek were snorkeled between the lake and Spring Creek Road on August 13. The creek was 2.4-6 m wide, had moderate flow and LWD, and was $11.7^{\circ} \mathrm{C}$. Spring creek had the highest density of rainbow trout of all the streams snorkeled in 2001 (Tables 3 and 4). Some brook trout and sculpin were seen during the night snorkel. The extoparasitic protozoa Epistylis spp., was noted on a few of the rainbow trout. 
Table 3. Densities of rainbow trout $(\mathrm{Rb})$, brook trout $(\mathrm{Bk})$ and bull trout $(\mathrm{Bu})$ in streams surveyed by night snorkeling in the White Salmon River basin during 2001, and their mean habitat characteristics.

\begin{tabular}{|c|c|c|c|c|c|c|c|c|c|c|}
\hline Site & $\begin{array}{c}\mathrm{Rb} \\
\text { per } \\
100 \mathrm{~m}^{2} \\
\end{array}$ & $\begin{array}{c}\mathrm{Bk} \\
\text { per } \\
100 \mathrm{~m}^{2}\end{array}$ & $\begin{array}{c}\mathrm{Bu} \\
\text { per } \\
100 \mathrm{~m}^{2}\end{array}$ & $\begin{array}{c}\text { Temperature } \\
\left({ }^{\circ} \mathrm{C}\right)\end{array}$ & $\begin{array}{c}\text { Mean } \\
\text { Gradient } \\
(\%)\end{array}$ & $\begin{array}{l}\text { Mean } \\
\text { LWD }\end{array}$ & $\begin{array}{c}\text { Mean } \\
\text { Width } \\
\text { (m) }\end{array}$ & $\begin{array}{c}\text { Mean } \\
\text { Depth } \\
(\mathrm{cm})\end{array}$ & $\begin{array}{c}\text { Mean } \\
\text { Substrate } \\
(\mathrm{cm})\end{array}$ & $\begin{array}{c}\text { Mean } \\
\text { Cover } \\
(\%)\end{array}$ \\
\hline \multicolumn{11}{|l|}{ White Salmon River Basin } \\
\hline Middle Fork Buck Creek & 0.00 & 0.00 & 0.00 & 8.3 & 12.5 & 14.0 & 5.0 & 17 & 62 & 99 \\
\hline Buck Creek (lower) & 11.17 & 0.00 & 0.00 & 12.2 & 3.0 & 10.0 & 6.0 & 23 & 25 & 95 \\
\hline Buck Creek (dam) & 10.85 & 0.00 & 0.00 & 10.3 & 4.1 & 11.0 & 7.8 & 12 & 19 & 79 \\
\hline Spring Creek & 16.49 & 1.33 & 0.00 & 11.7 & 1.2 & 13.7 & 3.9 & 31 & 7 & 45 \\
\hline Lost Creek ${ }^{\mathrm{a}}$ & 0.20 & 0.20 & 0.00 & 5.0 & 1.3 & 15.5 & 7.5 & 28 & 17 & 10 \\
\hline Smokey Creek & 0.00 & 4.49 & 0.00 & 12.0 & 4.5 & 21.0 & 2.5 & 13 & 9 & 60 \\
\hline Cultus Creek (upper) & 8.82 & 0.19 & 0.00 & 10.0 & 1.9 & 7.5 & 2.9 & 15 & 11 & 54 \\
\hline Cultus Creek (lower) & 0.00 & 0.00 & 0.00 & 13.3 & 5.0 & 6.0 & 6.0 & 17 & 24 & 15 \\
\hline Little Goose Creek & 0.00 & 0.93 & 0.00 & 6.9 & 2.0 & 22.0 & 7.5 & 13 & 14 & 17 \\
\hline Meadow Creek (upper) & 3.43 & 0.00 & 0.00 & 7.2 & 2.5 & $---{ }^{b}$ & 10.5 & 9 & 12 & 40 \\
\hline Meadow Creek (lower) & 5.36 & 0.00 & 0.00 & 10.5 & 0.5 & 11.0 & 9.6 & 71 & 0 & 5 \\
\hline Mosquito Creek (upper) & 0.00 & 0.00 & 0.00 & 7.8 & 7.3 & 28.0 & 2.2 & 12 & 13 & 70 \\
\hline Mosquito Creek (lower) & 0.00 & 1.28 & 0.00 & 6.7 & 1.0 & 28.0 & 2.4 & 11 & 10 & 78 \\
\hline
\end{tabular}

a. Lost Creek becomes subterranean before reaching any major river. However, an irrigation ditch brings water from Lost Creek to Coyote Creek, a tributary to the White Salmon River.

b. Inadvertently not counted. 
Table 4. Densities of $O$. mykiss (rainbow trout and/or juvenile steelhead) $(\mathrm{Om})$, brook trout (Bk) and bull trout (Bu) in streams surveyed by night snorkeling in the Klickitat River basin during 2001, and their mean habitat characteristics.

\begin{tabular}{|c|c|c|c|c|c|c|c|c|c|c|}
\hline Site & $\begin{array}{c}\text { Om } \\
\text { per } \\
100 \mathrm{~m}^{2}\end{array}$ & $\begin{array}{c}\text { Bk } \\
\text { per } \\
100 \mathrm{~m}^{2}\end{array}$ & $\begin{array}{c}\mathrm{Bu} \\
\text { per } \\
100 \mathrm{~m}^{2}\end{array}$ & $\begin{array}{c}\text { Temperature } \\
\left({ }^{\circ} \mathrm{C}\right)\end{array}$ & $\begin{array}{c}\text { Mean } \\
\text { Gradient } \\
(\%)\end{array}$ & $\begin{array}{l}\text { Mean } \\
\text { LWD }\end{array}$ & $\begin{array}{l}\text { Mean } \\
\text { Width } \\
(\mathrm{m})\end{array}$ & $\begin{array}{l}\text { Mean } \\
\text { Depth } \\
(\mathrm{cm})\end{array}$ & $\begin{array}{c}\text { Mean } \\
\text { Substrate } \\
(\mathrm{cm})\end{array}$ & $\begin{array}{c}\text { Mean } \\
\text { Cover } \\
(\%)\end{array}$ \\
\hline \multicolumn{11}{|l|}{ Klickitat River Basin } \\
\hline Outlet Creek & 14.63 & 0.33 & 0.00 & 8.3 & 5.0 & 2.0 & 11.6 & 45 & 23 & 23 \\
\hline \multicolumn{11}{|l|}{ West Fork Klickitat R. } \\
\hline Below Falls \# 1 (RM 0.2) & 2.42 & 0.18 & 0.00 & 9.2 & 2.3 & 30.0 & 16.5 & 43 & $--^{d}$ & 10 \\
\hline Above 255 Bridge (RM 2.2) & 2.02 & 1.18 & 0.11 & 10.0 & 1.3 & 32.0 & 17.9 & 46 & 24 & 13 \\
\hline Above 255 Bridge (RM 4.3) & 1.85 & 1.70 & 0.74 & 7.2 & 2.5 & 0.0 & 13.6 & 48 & 17 & 3 \\
\hline \multicolumn{11}{|l|}{ Trappers Creek } \\
\hline Downstream of Falls ${ }^{\mathrm{a}}$ & 0.00 & 0.00 & 10.77 & 9.5 & 3.4 & 25.0 & 3.0 & 12 & 12 & 75 \\
\hline Upstream of Falls & 0.00 & 0.00 & 0.00 & 9.5 & & & & & & \\
\hline Near Adams Lake Road & 0.00 & 0.00 & 0.00 & 5.6 & 3.0 & 63.0 & 3.6 & 16 & 6 & 58 \\
\hline Clearwater Creek (RM 0.2) & 0.00 & 0.00 & 0.00 & 7.0 & 4.0 & 84.0 & 9.9 & 31 & 20 & 25 \\
\hline Two Lakes Stream, Below Falls & 4.06 & 2.86 & 0.07 & 5.2 & 4.2 & 26.5 & 13.8 & 23 & 5 & 35 \\
\hline \multicolumn{11}{|l|}{ Tributaries to Two Lakes Stream } \\
\hline Unnamed \#1 (lower) & 0.17 & 0.33 & 0.00 & 4.5 & 2.1 & 94.5 & 10.4 & 22 & 4 & 36 \\
\hline Unnamed tributary to unnamed \#1 & 0.28 & 2.54 & 0.00 & 4.0 & $---^{c}$ & 83.0 & 3.6 & 14 & 2 & 89 \\
\hline Klickitat R. below Castile Falls (RM 63.9) & $---{ }^{b}$ & 0.39 & 0.00 & 13.0 & 0.6 & 3.0 & 20.2 & 41 & 13 & 0 \\
\hline Klickitat River (RM 86.7) & 3.67 & 0.43 & 0.00 & 12.9 & 0.8 & 14.7 & 8.9 & 35 & 16 & 2 \\
\hline
\end{tabular}

a. Habitat values are the averages of the transects upstream and downstream of the falls.

b. Too many $O$. mykiss (100's) were observed to get an accurate count.

c. It was too dark to measure gradient at this transect.

d. Only bedrock and boulders were observed. 


\section{$\underline{\text { Tributaries of Cave Creek }}$}

Beaver Creek and two unnamed tributaries of Cave Creek were electroshocked during August and September. Cave Creek drains the low mountains to the southwest of the town of Trout Lake and enters the White Salmon River below Trout Lake. Water temperatures varied considerably in the various tributaries. Approximately $50 \mathrm{~m}$ of Beaver Creek were electroshocked just upstream of U.S. Forest Service (USFS) road 8631 on August 29. Water temperature was $13.3^{\circ} \mathrm{C}$, even though it had been $9.5^{\circ} \mathrm{C}$ only 2 weeks earlier. An abundant population of brook trout was found.

The two unnamed tributaries of Cave Creek were very cold, but had low flow ( $<2.0 \mathrm{cfs})$. Unnamed creek \# 1 joined Cave Creek at RM 3.5 (as measured from where Cave Creek is routed into an irrigation ditch near Highway 141). It was obviously spring fed at $5.8^{\circ} \mathrm{C}$ on August 29 , but only brook trout were found. Unnamed \# 2 joined Cave Creek at $\sim \mathrm{RM} 1.8$. It was also spring fed with water temperatures of $7.2^{\circ} \mathrm{C}$ at the upper site ( RM 1.9) on August 29 and $8.0^{\circ} \mathrm{C}$ at the lower site ( RM 0.6) on September 21. Brook trout were the only fish observed, and only at the lower site.

\section{$\underline{\text { Lost Creek }}$}

Lost Creek is an isolated, spring fed, stream that flows subsurface into lava flows, never reaching any river. However, an irrigation ditch withdraws water from Lost Creek and takes it over to Coyote Creek. Coyote Creek essentially ends west of the town of Trout Lake without reaching the White Salmon River. Although the probability is low of fish reaching the White Salmon River, we investigated the stream because there was a possible connection during flooding. Lost Creek was 5.7-10.0 m wide, low gradient $(<2 \%)$ and had moderate amounts of LWD (some were part of restoration efforts). The water temperature had decreased from $8.3^{\circ} \mathrm{C}$ during the day to $5.0^{\circ} \mathrm{C}$ at night. We snorkeled 200 meters of the creek at RM 5.0 and found rainbow and brook trout in very low densities (Table 3 ).

\section{$\underline{\text { Little Goose Creek }}$}

Little Goose Creek is a tributary of Trout Lake Creek. We night snorkeled a 100-m section just upstream of USFS road 8831 on July 2. Little Goose Creek was 5-10 m wide, low gradient (2\%), had good quantities of LWD (22), and was $6.9^{\circ} \mathrm{C}$. Brook trout were present at a very low density (Table 3 ). We observed two unidentified tadpoles and one tailed frog tadpole. 


\section{Smokey Creek}

Smokey Creek is a tributary of Little Goose Creek. A 100-m section, $200 \mathrm{~m}$ downstream of USFS road 8831, was night snorkeled July 9. The creek was 1.7-3.2 $\mathrm{m}$ wide, had $4.5 \%$ gradient with abundant LWD, and was $12.0{ }^{\circ} \mathrm{C}$. Only brook trout were seen in Smokey Creek, at a relatively high density (Table 3). We also observed thirteen smaller, unidentified salamanders.

\section{Cultus Creek}

Cultus Creek is a tributary of Trout Lake Creek. We night snorkeled 200-m sections on upper and lower Cultus Creek July 9-11. The upper site was located just upstream of USFS road 24 where the creek was $1.8-3.6 \mathrm{~m}$ wide, low gradient $(<2 \%)$, and $10.0^{\circ} \mathrm{C}$. No fish were seen at the upper site, but fourteen tailed frog tadpoles were counted. The lower site was just upstream of USFS road 88 where the creek was 4.1-11.4 m wide, had a gradient of 5.0\%, and was $13.3^{\circ} \mathrm{C}$. Rainbow trout densities were high, and a few brook trout were seen during the survey (Table 3 ). Tailed frog tadpoles were quite abundant, and a few Dicamptodon spp. salamanders were seen.

\section{Meadow Creek}

Meadow Creek is also a tributary of Trout Lake Creek. We night snorkeled a 100-m section on upper Meadow Creek, just upstream of USFS trail 26, on June 27, and a 200-m section on lower Meadow Creek, just upstream of USFS road 88, on June 26. Upper Meadow Creek was highly braided and shallow as it ran through a dense willow stand. It was 3-18 m wide, had a gradient of $2.5 \%$, and was $7.2^{\circ} \mathrm{C}$. Rainbow trout were present at a moderate density at the upper site (Table 3). The lower site was just upstream of USFS road 88 where the creek was 9-10 m wide and with some LWD. Lower Meadow Creek was typical of streams in meadow environments with a very low gradient $(0.5 \%)$, wide meandering bends, slightly incised cut banks, and a predominance of deep glide habitat. The lower site was $10.5^{\circ} \mathrm{C}, 3.0^{\circ} \mathrm{C}$ warmer than the upper site. Rainbow trout were also moderately abundant at the lower site. No other salmonids were seen, but Dicamptodon spp. salamanders were abundant.

\section{Mosquito Creek}

Mosquito Creek flows into and then out of Mosquito Lake before flowing into Trout Lake Creek. We night snorkeled two 100-m sections of the creek upstream of the lake on July 10. This is a fairly small stream with only low quality pools. The upper section (just upstream of USFS road 8854) was $1.9-2.5 \mathrm{~m}$ wide with moderately high gradient (> 7\%), and was $7.8^{\circ} \mathrm{C}$. No trout were seen in the upper section. Lower Mosquito Creek (just upstream of USFS road 8851) was $2.4 \mathrm{~m}$ wide, low gradient $(1 \%)$, and was $6.7^{\circ} \mathrm{C}$. Only three brook trout were seen in the lower section (Table 3). 


\section{Crofton Creek}

Crofton Creek is a tributary of Morisson Creek and comes off the southwest side of Mount Adams. We electroshocked a 200-m section above USFS trail 73 September 20. Crofton Creek was 1-4 m wide, moderate gradient (3-6\%), with heaps of LWD and muddy silt to small boulders, and $5.0^{\circ} \mathrm{C}$. No fish were found in Crofton Creek.

\section{Unnamed Tributaries to White Salmon River}

Six small, unnamed tributaries to the White Salmon River upstream of Cascade Creek were electroshocked October 23-24. The first five (east to west) tributaries crossed USFS road 101. The sixth tributary was just west of the end of the road. These were high gradient streams with low LWD and few pools. They appeared to be spring fed systems. Water temperatures during snow conditions were expectedly cold and ranged from 2.8 to $3.3^{\circ} \mathrm{C}$. All of these creeks had low densities of rainbow trout, as only a few fish were captured in each creek.

\section{Elmer Canyon Creek}

Elmer Canyon Creek is a small tributary of the White Salmon River that joins the river in the valley southeast of Trout Lake. We electroshocked a 50-m section of the creek just upstream of the Glenwood/Trout Lake road October 30. The creek was $<0.5 \mathrm{~m}$ wide and very low gradient near the road, and $7.1^{\circ} \mathrm{C}$. No fish were found in Elmer Canyon Creek.

\section{KLICKITAT RIVER BASIN}

We surveyed 71 stream sections during 2001 in the Klickitat River basin that were not sampled in 2000 (Table 2). Slightly more than 9,000 $\mathrm{m}$ of the mainstem Klickitat River and tributaries, and Fish Lake were sampled during summer and fall 2001. We electroshocked many of the smaller tributaries, rather than snorkeling them, in order to sample more streams; and also surveyed extensive areas in the West Fork Klickitat drainage, Diamond Fork drainage, the upper Klickitat River above Diamond Fork, and the Little Klickitat River drainage near Goldendale. Most of our work in the Klickitat River basin was done on the Yakama Indian Reservation The following areas in the basin were not on the reservation: Outlet Creek, Little Klickitat River drainage, and several drainages on the west side of the Klickitat River below the Leidl Bridge.

We found bull trout only in Trappers, Clearwater, and Little Muddy creeks; and in the West Fork Klickitat River. We also discovered bull trout in Two Lakes Stream and an unnamed tributary to Fish Lake Stream, both tributaries of the West Fork Klickitat River. In addition, bull trout were observed while night snorkeling in the West Fork Klickitat River just upstream of Yakama Nation road 255 bridge and at a site upstream of the bridge at RM 4.3. 


\section{$\underline{\text { Westside Streams }}$}

Westside Creeks - Klickitat to Leidl Bridge

We examined several streams in Snyder, Skookum, Wahkiacus, Dead, and Willis canyons between the town of Klickitat and the Leidl Bridge in late October. The canyons were either dry or with too little water to support fish $(<0.25 \mathrm{cfs})$, and therefore were not sampled. These tributaries were too warm or dry during the bull trout spawning season and thus would not support spawning or rearing.

\section{Outlet Creek}

Outlet Creek is a larger (30-50 cfs), spring fed system that enters the Klickitat River at RM 39.7. We night snorkeled a 200-m section of the creek October 9 beginning just above the confluence with the Klickitat River. Outlet Creek was 7.2-14.2 m wide and fast flowing with many rapids. It had a gradient of $5 \%$ with almost no LWD, and was $8.3^{\circ} \mathrm{C}$. Most of the pools were formed by boulders and bedrock rather than LWD. The riparian zone was well vegetated with grasses, sedges and forbs typical of spring dominated streams. The fast nature and high flow made surveying the center of the stream difficult in places. Thus we likely missed some fish and underestimated densities. The creek was very productive and had the highest density of $O$. mykiss of any of the streams we snorkeled in the Klickitat River basin (Table 4). We also found brook trout, sculpin, and juvenile coho salmon at low densities, along with a few adult coho salmon and adult hatchery steelhead.

\section{Big Muddy Creek}

Big Muddy Creek enters the Klickitat River at RM 53.8. The creek is usually turbid with glacial melt and has high flow. We electroshocked a 150-m section of the creek near Yakama Nation road 255 bridge on October 10 when the creek ran low (estimated at $<5 \mathrm{cfs}$ ) and reasonably clear. The bank-full width clearly indicated that high velocity flows scour the creek at times. The creek provided poor habitat for fish because there was no LWD, few pools, and too much fine sediment. Not surprisingly, we found no fish in the creek.

\section{West Fork Klickitat Drainage}

\section{West Fork Klickitat River}

The West Fork Klickitat River is fast flowing and enters the mainstem at RM 63.1. During our reconnaissance on the west fork we discovered a significant falls (\#1) approximately 0.3 miles above the confluence with the Klickitat River. The falls are almost vertical and 5-6 $\mathrm{m}$ in height, and are not described in any documents we have seen. It is likely that falls \#1 is a barrier to fish moving from the mainstem up the West Fork Klickitat River. A second falls (\#2) exists on 
the west fork at about RM 4.8 just below the confluence of Little Muddy Creek and Fish Lake Stream. This well documented falls is also 5-6 $\mathrm{m}$ in height and probably a barrier to upstream fish passage.

We night snorkeled 100-m sections at three sites on the West Fork Klickitat River July 1623: below falls \#1 (RM 0.3), just upstream of where Yakama Nation road 255 crosses the river (RM 2.2), and an upper site where the screw trap was installed (RM 4.3). The West Fork Klickitat River at these sites was 11-20 m wide, averaged about 2.0\% gradient (not including the falls), and was $7.2-10^{\circ} \mathrm{C}$. The fast flowing river was difficult to snorkel in some areas, especially in the thalweg.

Numerous $O$. mykiss, a few brook trout and juvenile chinook salmon (<150 mm), sculpin, and a single mountain whitefish were seen at the lower site below falls \#1 (Tables 2 and 4). No bull trout were seen below falls \#1. Brook trout and $O$. mykiss were abundant at both sites above road 255. Bull trout were also seen in the West Fork Klickitat River at the two sites above the bridge. We saw two bull trout at the road 255 bridge and ten at RM 4.3. All bull trout except one were $>150 \mathrm{~mm}$. Four unidentified tadpoles were counted at the road 255 site. We did not sample or conduct a reconnaissance survey between falls \#1 and the 255 bridge. If no additional falls are in this area, we would expect bull trout to occur in 4.6 miles of the West Fork Klickitat River from just above falls \# 1 to its beginning at the confluence of Fish Lake Stream and Little Muddy Creek. On October 17, we day snorkeled the $40 \mathrm{~m}$ comprising the large plunge pool directly downstream of falls \#1 to determine if adult bull trout were "stalled" below the falls. We observed a couple of $O$. mykiss and one adult steelhead, but no bull trout.

We fished a 1.5-m screw trap in the West Fork Klickitat River at RM 4.3 at various times from July 24 through October 17 (Table 5). The trap fished at least eighteen 24-hour periods during these dates yielding 41 brook trout and 31 O. mykiss. No bull trout were taken with the screw trap even though bull trout had been seen in the area during night snorkeling.

\section{Little Muddy Creek}

Crawford, Trappers, and Clearwater creeks are tributaries of Little Muddy Creek. Little Muddy Creek is clouded with glacial flour during much of the year. We electroshocked two sites on the creek July 25-30: an upper site (RM 2.0) near Crawford Creek and a lower site (RM 1.1) approximately $300 \mathrm{~m}$ above Trappers Creek. The Crawford Creek site was very high gradient with few pools or resting habitat. No fish were caught or seen at the upper site. The lower site had better habitat for salmonids, was lower gradient, and had some pools or protected areas. We electroshocked a $172 \mathrm{~mm}$ bull trout in this section of Little Muddy Creek. There were no obvious barriers where we electroshocked, so bull trout could be further upstream. 
Table 5. Days fished and catch from a $1.5 \mathrm{~m}$ rotary screw trap fished in the West Fork Klickitat River at RM 4.3 from July 23 through October 17, 2001.

\begin{tabular}{lccc}
\hline \multicolumn{1}{c}{ Week of } & $\begin{array}{c}\text { Number of Days } \\
\text { Fished }\end{array}$ & $\begin{array}{c}\text { Number of Brook } \\
\text { Trout }\end{array}$ & $\begin{array}{c}\text { Number of } O . \\
\text { mykiss }\end{array}$ \\
\hline July 22 & 3 & 11 & 0 \\
July 29 & 2 & 9 & 3 \\
& & 5 & 0 \\
August 5 & 1 & N/a & N/a \\
August 12 & 0 & 4 & 13 \\
August 19 & 2 & N/a & N/a \\
September 2 & 0 & 2 & 0 \\
September 9 & 2 & 0 & 3 \\
September 23 & 2 & & \\
& & 4 & 11 \\
September 30 & 2 & 4 & 1 \\
October 7 & 2 & 2 & 1 \\
October 10 & 1 & 2 & 0 \\
October 14 & 2 & & \\
\hline
\end{tabular}

\section{Clearwater Creek}

Clearwater Creek joins Little Muddy Creek 0.8 miles above Fish Lake Stream. The creek runs clear even when the Little Muddy is clouded with glacial flour. There is a series of four falls on Clearwater Creek between RM 0.2 and RM 0.5. Bull trout were observed from the confluence upstream to the first falls in 2000. The first falls are nearly vertical and 6-8 m high. Clearwater Creek was spring fed, had a high gradient, good flow, and a very high quantity of LWD. We electroshocked and night snorkeled the 100-m section between falls \#1 and \#2 on July 30 to determine if bull trout existed above an apparent barrier. No fish were found above falls \#1. The falls, presumably, is a barrier to fish movement up Clearwater Creek.

\section{Trappers Creek}

Trappers Creek joins Little Muddy Creek $250 \mathrm{~m}$ above Clearwater Creek and also runs clear when the Little Muddy is clouded with glacial melt. We night snorkeled four 100-m sections of this spring fed stream July 16-23. Two upper sections were high up on Trappers Creek, one upstream of, and one downstream of Adams Lake Road. The two upper sections were 2.6-4.1 m wide and low to moderate gradient (1-5\%), very high in LWD, and $5.6^{\circ} \mathrm{C}$. No fish were found in these sections. 
Two mid-sections were upstream and downstream of a small falls located at RM 2.1. The mid-sections of Trappers Creek were 1.8-3.8 m wide and low to moderate gradient (2.0-4.5\%), with much LWD, and $9.5^{\circ} \mathrm{C}$. We measured the first $100-\mathrm{m}$ section and found that it ended just below a $1.8 \mathrm{~m}$ high vertical waterfall. The second $100-\mathrm{m}$ section was measured above the waterfall. We were surprised to find that this small waterfall was apparently a barrier to bull trout on Trappers Creek. We saw 28 bull trout during our night snorkel in the section below the falls, the highest density recorded in 2001 (Table 4), and no bull trout or other fish above the falls.

\section{Cold Creek}

Cold Creek is a small tributary that flows beneath Potato Hill Road and reaches Fish Lake Stream from the west at $\sim$ RM 3.3. A 100-m section of the creek was electroshocked October 17. Cold Creek was low gradient, $2-3 \mathrm{~m}$ wide, with much LWD, and $4.2^{\circ} \mathrm{C}$. Only a few $O$. mykiss and 53 brook trout were captured. The creek appeared suitable for bull trout, however, none were found.

\section{Two Lakes Stream}

Two Lakes Stream flows into Fish Lake Stream downstream of Fish Lake. It originates at Two Lakes and has a number of smaller unnamed tributaries that feed into it. In September, the stream is actually several times larger than Fish Lake Stream where the two join. Two Lakes Stream was an estimated 15-20 cfs, whereas Fish Lake Stream was estimated at 3-5 cfs. A waterfall, approximately $8 \mathrm{~m}$ high, was discovered on Two Lakes Stream at approximately RM 0.8. We electroshocked a 100-m section above the falls at RM 0.9, just upstream of unnamed tributary \#2, on September 25. The creek at this site was 8-15 m wide, perhaps $2-3 \mathrm{cfs}$, and $9^{\circ} \mathrm{C}$. The substrate was bedrock with large boulders and the channel was scoured, obviously getting heavy flow at times. Brook trout (66) and O. mykiss (29) were abundant in this section. We found no bull trout above the falls.

We night snorkeled a 200-m section below the falls September 26. The creek at this site was 8.9-16 $\mathrm{m}$ wide, fast flowing, moderately high gradient $(4-6 \%)$, and $5.2^{\circ} \mathrm{C}$. Input from unnamed tributary \#2 lowered water temperature in the mainstem Two Lakes Stream from 9.0 to $5.2^{\circ} \mathrm{C}$. Two bull trout (>150 $\mathrm{mm}$ ) were seen during the snorkel survey, but we were unable to capture them to collect tissue samples. Brook trout and O. mykiss were moderately abundant in the section below the falls (Table 4).

We electroshocked and night snorkeled several unnamed tributaries of Two Lakes Stream. The tributaries were spring fed, very cold $\left(4.0-4.5^{\circ} \mathrm{C}\right)$ and typical habitat for bull trout. Unnamed tributary \#1 joins Two Lakes Stream just above the confluence with Fish Lake Stream at $\sim$ RM 0.05. This tributary was shocked at two sites October 3. A 150-m section was shocked at the lower site (RM 0.05) and a 100-m section was shocked at the upper site (RM 0.5). The creek was 5-10 m wide, highly braided, low gradient, and plugged with LWD. Although not measured, velocity appeared to be quite swift in this stream. Otherwise, it appeared perfect for bull trout. 
We only shocked a few brook trout at each site and one tailed frog tadpole. We then night snorkeled a $200-\mathrm{m}$ section of tributary \#1 at RM 0.1 on October 8, including some of the area we had electroshocked. We observed only brook trout and O. mykiss in very low densities (Table 4). At RM 0.1, another very small, unnamed tributary enters unnamed tributary \#1. We snorkeled a $100-\mathrm{m}$ section on this tributary and again found $O$. mykiss and brook trout in very low densities.

A 100-m section of unnamed tributary \#2 (RM 0.9; not on the map) to Two Lakes Stream was electroshocked September 25. The creek joined Two Lakes Stream 0.1 miles upstream of the falls. This stream was providing the majority of the flow in Two Lakes Stream, perhaps 6-8 cfs of the estimated $10 \mathrm{cfs}$ flowing in Two Lakes Stream at the falls. Water temperature was also much cooler at $4.5^{\circ} \mathrm{C}$ versus $9.0^{\circ} \mathrm{C}$ in the mainstem. The two unnamed tributaries to Two Lakes Streams (\#1 and \#2) are clearly two of the most important sources of cold, spring fed water in the Fish Lake Stream drainage. Unnamed tributary \#2 forked about $50 \mathrm{~m}$ above where we began electroshocking, with most of the water coming out of the west fork. A few brook trout were taken in this stream, but no bull trout.

\section{Unnamed Tributaries to Fish Lake Stream}

We electroshocked two small tributaries in the Fish Lake Stream drainage. One unnamed tributary (WRIA code number 30-0550) joins Fish Lake Stream below the confluence with Two Lakes Stream at RM 5.0. This creek was $2-4 \mathrm{~m}$ wide, low to moderate gradient, with a bedrock and small boulder substrate, good pools, and $8.5^{\circ} \mathrm{C}$. We found six bull trout (111-174 mm) and several O. mykiss in the 100-m section shocked September 26 at RM 1.5. We did not determine the upstream limit of bull trout in this stream nor whether any falls were present. Presumably, bull trout inhabit the stream at least down to the confluence with Fish Lake Stream. We collected a tissue sample from each bull trout for DNA analysis. One tailed frog tadpole was also captured.

We electroshocked $100 \mathrm{~m}$ of a second, very small, unnamed stream that we believe flowed into the aforementioned unnamed tributary to Fish Lake Stream (30-0550). However, we did not take the time to locate the confluence of this stream to verify this assumption. The creek was approximately $2 \mathrm{~m}$ wide, low gradient and low flow, and $5.6^{\circ} \mathrm{C}$. No fish were taken in the $100-\mathrm{m}$ section shocked September 26.

\section{Fish Lake Stream and Fish Lake}

Fish Lake is situated in a large basin 1.8 miles south of Howard Lake. The creek from Howard Lake flows to Fish Lake and is the actual source of Fish Lake Stream. The outlet of Fish Lake is at RM 7.6. We electroshocked approximately 300 meters of Fish Lake Stream just below the outlet of the lake on October 2. The stream was low gradient, 4-6 m wide, had some good pools with LWD, and was $10^{\circ} \mathrm{C}$. We caught 109 O. mykiss and 156 brook trout in this area, but no bull trout. Two tailed frogs, three tailed frog tadpoles, and one unidentified tadpole were observed. 
We gillnetted Fish Lake October 15. The 0.7-mile-long lake had a rich algal bloom in October and the shallow areas of the lake were chocked with vegetation. The water temperature was $8.2^{\circ} \mathrm{C}$. We made 6 net sets during the day in both shallow and deep areas, and captured only brook trout and $O$. mykiss. We captured 19 O. mykiss and 11 brook trout. No bull trout were captured. Most fish were released in good condition, however, six mortalities were retained by tribal personnel for disposition.

\section{Howard Lake Stream}

The stream leading from Howard Lake and one small unnamed tributary to the north were electroshocked October 1, approximately $300 \mathrm{~m}$ downstream from Howard Lake. The unnamed tributary was $0.5-1 \mathrm{~m}$ wide, formed small pools, and was $7.0^{\circ} \mathrm{C}$. No fish were taken in the $100-\mathrm{m}$ section shocked. The outlet stream was $1-2 \mathrm{~m}$ wide with pools to $4 \mathrm{~m}$ wide, and was $6.7^{\circ} \mathrm{C}$. Eight $O$. mykiss and five brook trout were found in the $150-\mathrm{m}$ section. No bull trout were taken in either stream.

\section{Genetic Analysis}

We collected 20 tissue samples from Trappers Creek bull trout and 6 tissue samples from the unnamed tributary to Fish Lake Stream (30-0550) bull trout. Preliminary results of genetic analysis suggest that these fish are part of the wide ranging coastal bull trout group (Paul Spruell, University of Montana, Personal Communication). Klickitat River bull trout appear to be more closely related to Willamette River fish rather than closer Hood River or Deschutes River bull trout.

\section{Upstream of West Fork}

The source of the Klickitat River is at RM 95.7 near Goat Rocks. The river drains a large basin as it heads east and then bends south near the confluence of Diamond Fork. Many small tributaries and Huckleberry Creek join the upper Klickitat River. Upstream of the Diamond Fork, most of the upper basin is in a roadless "Primitive Area" and access to the river is very limited. A four-wheel drive road follows the river to just beyond McCormick Meadow at RM 86.7, and with extreme care, a vehicle can get to RM 88.4. Beyond that, all access is limited to horses or walking. This presented numerous logistical problems and reduced our ability to conduct night snorkeling in the upper basin. 
The mainstem Klickitat River below Castile Falls was 13-28 m wide and low gradient (< $1 \%$ ), had little LWD, and was $13.0^{\circ} \mathrm{C}$. We night snorkeled two 100 -m sections July 17 at RM 63.9. Each section had a deep pool where it was difficult to see to the bottom. Fish were abundant in the shallower areas (Table 4). Juvenile $O$. mykiss and juvenile chinook salmon $(<150$ $\mathrm{mm}$ ) were so numerous (100's +) that we could not count them all. We also observed a few brook trout, some juvenile coho salmon, numerous sculpin, and a few mountain whitefish. No bull trout were seen.

\section{Chaparral Creek}

Chaparral Creek joins the mainstem from the west above Castile Falls at RM 68.1. A 125$\mathrm{m}$ section of the creek was electroshocked August 28 at RM 1.8. Chaparral Creek was about $1 \mathrm{~m}$ wide with a few deep pools, lots of fine silt, a flow of about $0.25 \mathrm{cfs}$, and $11.7^{\circ} \mathrm{C}$. The stream was intermittent in this area. Twenty five $O$. mykiss were captured in the creek. No bull trout were taken.

\section{Pearl Creek}

Pearl Creek joins the Klickitat River mainstem from the west at RM 69.5. Two hundred meters were shocked upstream of the Yakima Nation road 259 August 28. Pearl Creek was 1-3 $\mathrm{m}$ wide with good quantities of LWD, low flow, clear, with boulders to medium cobble, and 9.7 ${ }^{\circ}$. No fish were taken in Pearl Creek.

\section{Elkhorn Creek}

Elkhorn Creek is a small tributary of Huckleberry Creek that flows from the south to join Huckleberry Creek just above the confluence with the mainstem. Approximately 300 meters of the creek were electroshocked August 1 starting at RM 0.1. Elkhorn Creek was 1-3 m wide with lots of LWD forming pools and $11.2^{\circ} \mathrm{C}$. Fourteen $O$. mykiss and one brook trout were shocked in Elkhorn Creek. No bull trout were seen. A hike across Elkhorn Creek later in August revealed that the lower section near the confluence with Huckleberry Creek was dry.

\section{Huckleberry Creek}

Huckleberry Creek drains several miles of a large, roadless, basin in the upper Klickitat River area south of the mainstem. Two sites were electroshocked. The lower site was at RM 1.1 and the upper site was at RM 3.1. The creek at the upper site was high gradient, 2-3 m wide, low flow, and $12.2^{\circ} \mathrm{C}$. Huckleberry Creek at the lower site was low gradient, $4-5 \mathrm{~m}$ wide, rich in 
LWD, and $7.8^{\circ} \mathrm{C}$. We shocked about $450 \mathrm{~m}$ of Huckleberry during August 2001 and found no trout.

We suspected that a barrier prevented fish movement upstream and discovered two significant waterfalls on Huckleberry Creek downstream of where we had electroshocked. The highest falls, at RM 0.55, was an astonishing 25-30 m high and nearly vertical. A second falls about 6 meters high existed a few hundred meters above the first falls. We hiked into the canyon and were able to reach the creek at a site $300 \mathrm{~m}$ below the first falls. We saw O. mykiss in Huckleberry Creek below the first waterfall, indicating that the waterfall was likely the upstream limit of fish.

\section{Upper Klickitat River (Mainstem)}

We night snorkeled three 100-m sections of the mainstem Klickitat River above McCormick Meadow July 31 starting at RM 86.7. The river in this area was 6.6-11.2 m wide, low gradient $(<1 \%)$ with moderate amounts of LWD and good pools, and $12.8-13.0^{\circ} \mathrm{C}$. We found many $O$. mykiss and juvenile chinook salmon $(<150 \mathrm{~mm})$, a few brook trout, and eight unidentified tadpoles (Table 4). We saw no bull trout.

We electroshocked approximately $400 \mathrm{~m}$ of the mainstem near RM 91.5 August 21 and 27. Electroshocking was difficult at the site due to the width and discharge of the stream, and the amount of LWD. Night snorkeling would be more efficient at this location if access was not so difficult. A small log jam separated the section into two sites. Only two, larger, O. mykiss were collected in the 350-m section above the log jam, while eight $O$. mykiss were taken in a 50-m section below the log jam. This small log jam was apparently limiting the number of $O$. mykiss upstream. It was not clear as to why reproduction upstream would not fully seed the habitat, but certainly the density of $O$. mykiss was very low. We found no bull trout while electroshocking.

We examined all of the small tributaries flowing into the mainstem from the north. Only a handful had sufficient water to support fish life. Unnamed tributary \#1 joined the mainstem at RM 79.9 (WRIA code number 30-0754) and was electroshocked on August 1. The stream was high gradient, flow was approximately $1.0 \mathrm{cfs}$, but it was mostly less than 1 foot deep. No fish were observed in $100 \mathrm{~m}$ of stream.

Unnamed tributary \#2 (WRIA number 30-0777) joins the mainstem at RM 86.55. We electroshocked $100 \mathrm{~m}$ on July 31 , when the stream was $9.8^{\circ} \mathrm{C}$. This is a small stream approximately 1-3 m wide with about $1.0 \mathrm{cfs}$ of water, low gradient, lots of pool habitat and LWD, and good overhead cover. We found a single $O$. mykiss, a few brook trout, one tailed frog tadpole, and one unidentified tadpole.

Unnamed tributary \#3 (WRIA number 30-0818) joins the mainstem at RM 87.95. This was a very small stream with only about $0.5 \mathrm{cfs}$ of water. The water was $7^{\circ} \mathrm{C}$ on August 20. No fish were found in $\sim 50 \mathrm{~m}$ of stream. 
Unnamed tributary \#4 (WRIA number 30-0819) joins the mainstem at RM 88.4. We electroshocked a small unnamed tributary of this unnamed tributary on August 20. The stream shocked is not on the map, but enters stream 30-0819 from the north. The stream meanders through two different meadows, where it is slightly incised, with undercut banks and a few nice pools. Typical of meadow habitats, riparian vegetation was mostly limited to sedges, grasses and low forbs. The stream was flowing about $1.0 \mathrm{cfs}$ and was $11^{\circ} \mathrm{C}$, and $O$. mykiss were abundant.

Unnamed tributary \#5 (WRIA number 30-0822) joins the mainstem at RM 89.7. We electroshocked this unnamed tributary on August 21 at RM 0.035 . The stream was $8.3^{\circ} \mathrm{C}$ and only about $0.5 \mathrm{cfs}$. The stream was mostly less than 1 foot deep and pool habitat was limited. We electroshocked $\sim 200 \mathrm{~m}$ and captured eleven $O$. mykiss.

Unnamed tributary \#6 joins the mainstem at RM 91.8. This stream is not on the map and does not have a WRIA code number. This stream was $6.1{ }^{\circ} \mathrm{C}$ on August 27. The stream was 2.1 $\mathrm{m}$ wide, gradient was 2.5-3.0, and LWD was abundant. This was another stream that looked like a "typical" bull trout stream; flow was $\sim 1.5 \mathrm{cfs}$ and the stream was obviously spring fed. However, no fish were found electroshocking $80 \mathrm{~m}$ of stream.

\section{Diamond Fork Drainage}

Diamond Fork drains a large basin northeast of the Klickitat River and enters the mainstem at RM 76.8. Many unnamed tributaries enter the Diamond Fork from both the west and east. We did not survey tributaries in Tract $\mathrm{C}$ of the Yakama Indian Reservation due to the difficulty of access, as it is accessible only through Yakima. We electroshocked a total of 1,970 m at thirteen locations on nine unnamed tributaries in the Diamond Fork drainage September 10-19 (Table 2). The tributaries ranged from $<1 \mathrm{~m}$ to $5 \mathrm{~m}$ wide with low to moderate gradient. Temperatures ranged from $5.0^{\circ} \mathrm{C}$ on the west to $10.5^{\circ} \mathrm{C}$ in a tributary on the east. Trout were virtually absent in smaller tributaries from the west and east, but $O$. mykiss were abundant in three of the warmer tributaries $\left(8.5-10.5^{\circ} \mathrm{C}\right)$ on the east side.

Working upstream, unnamed \#1 entered the Diamond Fork at RM 0.5 from the east. No fish were captured. Unnamed \# 2 (WRIA number 30-0692) entered the Diamond Fork from the east at RM 3.65. We captured 28 O. mykiss in $180 \mathrm{~m}$ of electroshocking. One hundred forty and $100 \mathrm{~m}$ were sampled at RM 0.15 and 0.65 , respectively, in unnamed tributary \#3 (WRIA number 30-0693) which entered the Diamond Fork at RM 3.75, but no fish were found.

The most promising area in the Diamond Fork drainage was unnamed tributary \#4 (WRIA number 30-0695) that entered Diamond Fork from the west at RM 4.1. An unnamed creek (WRIA number 30-0696) branched off to the south at RM 1.2. Water temperatures in this system ranged from $5.0-7.2^{\circ} \mathrm{C}$ and there was plenty of LWD creating pools and protective habitat. Aquatic vegetation was abundant in this spring-fed stream. We electroshocked $100 \mathrm{~m}$ at RM 1.15 and another $100 \mathrm{~m}$ at RM 1.5. Brook trout were numerous at both sites, but $O$. mykiss were found only at the lower site. We also electroshocked two sites on the southern tributary, $200 \mathrm{~m}$ 
at RM 0.05 and $150 \mathrm{~m}$ at RM 0.2. Brook trout were the only species captured. Thirty two were captured at the lower site, while only nine were captured at the upper site.

Unnamed tributary \#5 (WRIA number 30-0697) entered the Diamond Fork from the east at RM 4.4. This was another larger stream with good flow, but warmer at $10.5^{\circ} \mathrm{C}$. We electroshocked $260 \mathrm{~m}$ of stream at RM 0.05 and captured 56 O. mykiss.

Unnamed tributary \#6 (WRIA number 30-0698) entered the Diamond Fork from the east at RM 5.6. We electroshocked $245 \mathrm{~m}$ of stream at RM 0.2 and captured 25 O. mykiss.

Unnamed tributaries \#7, 8 and 9 are three very small steams that enter the Diamond Fork at RM 5.8, 5.9 and 6.1. Tributaries \#7 and 9 enter from the east side and were fairly cool at 5.2 and $6.4^{\circ} \mathrm{C}$, respectively. Tributary \#8 enters from the west side and was also fairly cool at $6.7^{\circ} \mathrm{C}$. All three streams were electroshocked just upstream from their confluence with the mainstem Diamond Fork. A single O. mykiss and one brook trout were captured in tributary \#7, while no fish were captured in the other two streams.

\section{Piscoe Creek}

Piscoe Creek drains an eastside basin and enters the Klickitat River at RM 75.1. We electroshocked a 100-m section at RM 4.4 August 15. The creek was about $2 \mathrm{~m}$ wide, low gradient, had a few small pools, and was a warm $15^{\circ} \mathrm{C}$. We captured $48 \mathrm{O}$. mykiss, and they were the only fish species observed.

\section{Yedlick Creek}

Yedlick Creek enters the Klickitat River from the east just above Castile Falls. The creek was 1-1.5 m wide, heavily incised with lots of sediment, low gradient and low flow (about 0.5 cfs), and $10.5^{\circ} \mathrm{C}$. We electroshocked a 100-m section above Yakama Nation road 251 September 26, and O. mykiss were common. No other fish were captured in Yedlick Creek.

\section{Swamp Creek}

Swamp Creek enters the Klickitat River from the east at Castile Falls. The creek was 3-4 $\mathrm{m}$ wide, high gradient with a flow of $1-2 \mathrm{cfs}$, and $10.0^{\circ} \mathrm{C}$. Swamp Creek was electroshocked upstream starting just beyond the end of Yakama Nation road 251 September 26. Tailed frog tadpoles and $O$. mykiss were abundant. We captured no bull trout or other salmonids. 


\section{Cedar Creek}

Cedar Creek is a tributary of Surveyors Creek at RM 3.5. The creek was $9.8^{\circ} \mathrm{C}, 1-2 \mathrm{~m}$ wide, low gradient with pools to $3.5 \mathrm{~m}$ wide, and had lots of LWD. Flow was very low and the stream was intermittent at this location. We electroshocked a 100-m section of Cedar Creek at RM 0.7 October 2 and captured 41 O. mykiss. We found no other fish in Cedar Creek.

\section{Eastside Streams Near Lower Boundary of Yakama Indian Reservation}

We examined several small creeks and tributaries upstream of Yakama Nation road 207 October 16. Dry, Blue, Brush, and several unnamed creeks were dry. We also hiked up White Creek approximately 1.5 miles to the confluence with Brush Creek looking for potential spring inflow. White Creek above the confluence was 2-3 m wide, moderate gradient, with boulders and pools, perhaps 1.5 or $2.0 \mathrm{cfs}$ of discharge, and $9.5^{\circ} \mathrm{C}$. Brush Creek was $2-2.5 \mathrm{~m}$ wide, had only about $0.5 \mathrm{cfs}$, and was $8.3^{\circ} \mathrm{C}$. No significant cold water springs were located. Because Yakama Nation personnel routinely sample White Creek, we did not shock or sample these creeks.

We electroshocked a 100-m section of a Summit Creek at RM 12.75 on October 10. The creek was $1.5 \mathrm{~m}$ wide with pools to $3 \mathrm{~m}$, low gradient with a flow of about $1 \mathrm{cfs}$, choked with much brush, and $5^{\circ} \mathrm{C}$. We captured many brook trout and a few $O$. mykiss.

\section{Little Klickitat River Drainage}

The Little Klickitat River joins the Klickitat River at RM 19.8. It originates in the Simcoe Mountains north of Goldendale as many small tributaries. Bowman, Mill, Devils Canyon, West Prong, Butler, and East Prong creeks are tributaries of the Little Klickitat River that we electroshocked. Typical of other eastside tributaries, the Little Klickitat River and its tributaries are primarily snow-melt driven systems, with high water in the spring and very low, warm water during late summer and early fall.

\section{Bowman Creek}

Bowman Creek enters the Little Klickitat River at RM 1.2, west of Goldendale. We electroshocked two 100-m sections of Bowman Creek October 31. The creek at Lower Bowman Camp (RM 13.) was 3-5 m wide, low gradient with some LWD and pools, and $6.7^{\circ} \mathrm{C}$. The creek at Upper Bowman Camp (RM 14.9) was also low gradient, 1.5-3 m wide with lots of LWD and some pools, and $7.5^{\circ} \mathrm{C}$. Both section had numerous $O$. mykiss. No bull trout or other salmonids were captured in Bowman Creek. 


\section{Mill Creek}

Mill Creek enters the Little Klickitat River at RM 3.6 near Blockhouse. The creek forks at RM 12.7, above where Devils Canyon Creek joins Mill Creek. We electroshocked 100-m sections at RM 12.8 on October 31, and at RM 14.3 on November 12. The lower section was 3$5 \mathrm{~m}$ wide, low gradient with lots of LWD and some pools, and $7.2^{\circ} \mathrm{C}$. The upper section was sampled on a cold day when the water temperature was $4.3{ }^{\circ} \mathrm{C}$. It was $2-3 \mathrm{~m}$ wide and moderate gradient with a few pools. Numerous $O$. mykiss were collected at both locations, and were the only fish collected. We collected tissue samples from 20 O. mykiss on November 14 for DNA analysis. All $O$. mykiss samples are archived at the WDFW Genetic Lab in Olympia. Analyses will be conducted if funds become available.

\section{Devils Canyon}

Devils Canyon Creek is a tributary of Mill Creek at RM 10.3 and drains the deep Devils Canyon to the east of Monument Road. We electroshocked a total of $180 \mathrm{~m}$ at two sites (RM 4.5 and 5.4) on Devils Canyon Creek November 12. The creek at both sites was high gradient, 1.5 to $2 \mathrm{~m}$ wide with about $2 \mathrm{cfs}$ flow, and $2.5^{\circ} \mathrm{C}$ (winter conditions resulted in very cold water temperature). Although high gradient, the habitat looked good for supporting fish. We collected 48 O. mykiss and one tailed frog tadpole. We collected tissue samples from 20 O. mykiss on November 14 for DNA analysis.

\section{West Prong Little Klickitat River}

West Prong Little Klickitat River drains a large canyon that begins below Indian Rock and runs southeast to become the Little Klickitat River when it joins East Prong Little Klickitat River on the east side of Highway 97. We electroshocked a total of 200 meters in three reaches on West Prong Little Klickitat November 7: lower West Prong Little Klickitat (RM 3.75), an east tributary of lower West Prong (WRIA code number 30-0138), and upper West Prong Little Klickitat (RM 6.0). The lower section was moderate gradient, 2-3 $\mathrm{m}$ wide with some LWD and pools, and $0^{\circ} \mathrm{C}$ (winter conditions resulted in the low water temperature). Sculpin and $O$. mykiss were abundant in the lower section. The stream at the upper site was about $1.5 \mathrm{~m}$ wide, moderate gradient with some LWD and small pools, and $0^{\circ} \mathrm{C}$. No fish were shocked in the upper section. The USGS map indicates a falls at RM 4.35, which may explain the lack of fish at the upper site. The small tributary from the east was $1.5 \mathrm{~m}$ wide with a lot of LWD, good pool habitat, and perhaps $1.0 \mathrm{cfs}$ discharge. We were only able to sample a short section of this creek just upstream of the confluence before our equipment broke. Moderate densities of $O$. mykiss were found in the unnamed tributary. We also collected tissue samples from 20 O. mykiss from the West Prong Little Klickitat on November 14 for DNA analysis. 


\section{Butler Creek}

Butler Creek drains a large canyon that begins to the east of Indian Rock and runs southeast to join the East Prong Little Klickitat River at RM 0.1. We shocked a total of $300 \mathrm{~m}$ in four reaches on Butler Creek: RM 0.9, 3.6, 7.65, and 8.5. The lower reach was just west of Highway 97. The creek at this site was about 1.5-2 $\mathrm{m}$ wide with a few pools to $4 \mathrm{~m}$, low gradient, and $7.2^{\circ} \mathrm{C}$. Sculpin, dace, and $O$. mykiss were taken at the lower site.

We shocked the three upper sites on November 5-6 during freezing conditions. The water temperature at this time ranged from 0 to $2^{\circ} \mathrm{C}$. The creek was $1-2 \mathrm{~m}$ wide with some small pools. We found no fish at RM 8.5, however, O. mykiss were abundant at RM 3.6 and 7.65.

\section{East Prong Little Klickitat River}

East Prong Little Klickitat River drains a basin east of Highway 97 and joins West Prong Little Klickitat River to become the Little Klickitat River. We electroshocked a 75-m section of the creek near Brooks Memorial Park at RM 3.9 on October 29. The creek was 1.5-2 m wide, low gradient, with some LWD and pools, and $7.2^{\circ} \mathrm{C}$. O. mykiss, sculpin, and dace were captured in East Prong Little Klickitat River.

We also examined all of the eastern tributaries to the East Prong Klickitat River. These streams were either dry or with too little water to support fish ( $<0.25 \mathrm{cfs})$, and therefore were not sampled. These tributaries were too warm or dry during the bull trout spawning season and thus would not support spawning or rearing.

\section{$\underline{\text { DISCUSSION }}$}

Considerable effort was expended to determine if bull trout were present in streams throughout the White Salmon and Klickitat river basins. Despite our efforts and those of Byrne et al (2001), we have not been able to find bull trout in the White Salmon River basin. Since historical records suggest bull trout were present, it appears that bull trout in the White Salmon River have been extirpated, are confined to the mainstem where sampling is very difficult, or exist in a very small, isolated population that will be extremely difficult to locate. Efforts to locate these fish should continue on a smaller scale in the future, perhaps targeting the mainstem and Northwestern Lake.

We sampled a tremendous number of streams in the Klickitat River basin. In general, we traded certainty for quantity, utilizing single pass electroshocking where feasible. Much of the Klickitat River basin on the Yakama Indian Reservation had not been sampled previously. Therefore, we felt it was prudent to learn about as many streams as possible. Still, bull trout were found only in the West Fork Klickitat River drainage, where they had already been documented. We were able to add the Fish Lake Stream drainage as known habitat. Bull trout were not found 
in unnamed tributaries \#1 and \#2 to Two Lakes Stream. However, the size, spring fed nature, and general habitat characteristics suggest that further sampling is warranted on these streams. No sampling was conducted in the Two Lakes Stream basin upstream of unnamed tributary \#2. There are numerous streams and lakes in the area where additional efforts are also warranted.

One of our objectives was to determine if bull trout in the West Fork Klickitat River migrate back and forth with the mainstem. It appears at this time, that the West Fork population is isolated from the mainstem based on three results observed this year. First, no bull trout were captured in the rotary screw trap, even though we consistently caught brook trout and O. mykiss. Second, none of the fish observed in the West Fork were greater than $300 \mathrm{~mm}$. Third, no bull trout were observed congregating below the falls at RM 0.3 .

Bull trout are clearly susceptible to capture in rotary screw traps (Buchanan et al, 1997; Thiesfeld et al. 1999; Hemmingsen et al. 2001). Since we didn't install the trap until July, we may have missed the main migration period. Metolius River, Oregon, adfluvial bull trout migrate downstream nearly year around, although the peak is generally in April and May (Riehle et al. 1997; Thiesfeld et al. 1999). Fluvial bull trout in the John Day River and Mill Creek (Walla Walla River basin) migrate downstream from spring through fall (Hemmingsen et al. 2001), although traps were not fished in the winter. In the Lewis River, downstream migrating bull trout were captured in a trap fished during June. Hood River bull trout are generally only captured in the spring or fall (Rod French, Oregon Department of Fish and Wildlife, The Dalles, Oregon, personal communication). Fishing a screw trap during the expected peak outmigration in April, May and June would help determine if the West Fork Klickitat River bull trout are migrating downstream and perhaps contributing to the population in the mainstem.

Fluvial and adfluvial bull trout populations generally have fish larger than $300 \mathrm{~mm}$ (e.g. Fraley and Shepard 1989; Thiesfeld et al. 1996, Sexauer and James 1997; Hemmingsen 2001). Since we found no fish greater than $250 \mathrm{~mm}$, it is unlikely that a fluvial life history exists. We suspected that the falls at RM 0.3 was a barrier to upstream fish passage. However, we did not find any fish "stalled" there in mid-October. It would be beneficial to repeat the surveys below the falls during July, August and September to determine if bull trout are attempting to migrate upstream. Finally, we will spend time this winter trying to capture bull trout in the mainstem that can be radio-tagged. If successful, these fish should help determine if mainstem fish came from the West Fork Klickitat River or not.

We discovered bull trout in two tributaries in the Fish Lake Stream drainage of West Fork Klickitat. These represent the first published records of bull trout from this drainage. Six bull trout (111-174 mm) were captured in a small unnamed tributary to Fish Lake Stream and two were observed during a night snorkel of Two Lakes Stream. Two Lakes Stream specimens were found just below a 6-8 m high waterfall located 0.8 miles above the confluence with Fish Lake Stream. Additional sampling upstream of the falls should be conducted to verify that the falls are the upstream limit.

We found no bull trout in several nearby tributaries of Two Lakes and Fish Lake streams, even though these tributaries seemed perfect for bull trout. The water was cold, gradients low, 
and pools and protective habitat were available. We would expect to find bull trout in some of these tributaries with additional sampling. Bull trout should also be in Fish Lake Stream, especially below the confluence with Two Lakes Stream and near the confluence with the unnamed tributary where bull trout exist.

The West Fork Klickitat River and its tributaries are clearly the "critical" habitat for bull trout in the upper basin. The West Fork Klickitat River and tributaries are primarily spring or glacial fed and are cold. This drainage has good flow year-round and provides three times as much water per square mile as does the rest of the Klickitat River above the West Fork (Cline, 1976). Base flows of late summer and fall are sustained by the West Fork Klickitat River through ground-water discharge and more water released from storage in glaciers (Cline, 1976).

Despite our extensive sampling in the upper basin, Diamond Fork, and the remainder of the basin, we were not able to find any additional bull trout, and usually found streams that were too warm to support healthy bull trout populations. The streams in the lower basin below Outlet Creek, including the Little Klickitat River drainage, appear to have little influence from springs or glacier melt. These streams typically were either dry, or at their lowest point, during the fall spawning period. Summer water temperatures often exceed $15^{\circ} \mathrm{C}$. Therefore it is highly unlikely that any of the streams below Outlet Creek support spawning or rearing bull trout. These streams might provide occasional foraging areas for bull trout during the winter and spring, but they should not be considered critical habitat.

In the upper basin upstream of Castile Falls, we were somewhat surprised that we did not find any bull trout. Surrounding the upper Klickitat River are bull trout populations in the West Fork Klickitat River to the south, in Ahtanum Creek and Tieton River to the north, and in the lower Lewis River to the west. Suitable water temperatures, flow, and habitat were noted in a number of smaller tributaries to the mainstem and at a number of westside tributaries to the Diamond Fork. As we explained above, we did not sample the upper Diamond Fork drainage due to the travel distance required to get there. Additional sampling should be conducted there to solidify our conclusion that bull trout are not present in upper basin. If this conclusion holds, it suggests that Castile Falls is, and has been, a barrier to bull trout.

Bull trout were usually found in low density in the Klickitat River basin, except for Trappers Creek. Our bull trout densities from night snorkeling ranged from 0.07 to 10.77 fish/100 $\mathrm{m}^{2}$. Trappers Creek and Clearwater Creek were the only streams that exceeded 1.0 bull trout $/ 100 \mathrm{~m}^{2}$. Bull trout densities from night snorkel estimates in Metolius River tributaries ranged from 4.82 to $17.68 \mathrm{fish} / 100 \mathrm{~m}^{2}$, although these are considered high in comparison to most other systems (Riehle et al. 1997). Mean bull trout densities in Warm Springs River and Shitike Creek, Oregon, range between 0.5-0.63 fish/100 $\mathrm{m}^{2}$ and 2.5-3.2 fish/ $100 \mathrm{~m}^{2}$, respectively (Brun and Dodson 2001). Sexauer and James (1997) reported juvenile bull trout densities in four central Washington streams ranged from 0.34 to $1.85 \mathrm{fish} / 100 \mathrm{~m}^{2}$. Adams and Bjornn (1997) report densities from daytime snorkeling ranged from 0.0 to 9.5 fish/100 $\mathrm{m}^{2}$ in the Weiser River system, Idaho. 
During this study, we documented several waterfalls that we believe act as barriers to fish movement. Falls \# 1 on the West Fork Klickitat River probably prevents movement from the mainstem Klickitat River up the West Fork. A small $1.8 \mathrm{~m}$ falls on Trappers Creek 2.1 miles above the confluence with Little Muddy Creek apparently prevents movement of bull trout beyond the falls. A 6-8 m falls on Two Lakes Stream 0.8 miles above the confluence with Fish Lake Stream also likely prevents fish movement above the falls on Two Lakes Stream. We found no bull trout above this falls. A significant 25-30 m falls on Huckleberry Creek in the upper Klickitat River drainage prevents fish movement up Huckleberry Creek above the falls.

Bull trout exist in the mainstem Klickitat River, apparently in low numbers. The mainstem has not been thoroughly sampled for bull trout below Castile Falls and we recommend a more thorough sampling program that targets bull trout. We will attempt to capture bull trout by angling in the Klickitat River below the hatchery during the early months of 2002.

Densities of $O$. mykiss were generally low when compared to other local streams. In the Wind River, rainbow trout and juvenile steelhead densities at a variety of sites ranged from 2.8 to 110 fish/100 $\mathrm{m}^{2}$ during sampling conducted from 1996 through 1999 (Patrick J. Connolly, USGSColumbia River research Laboratory, Cook, Washington, personal communication). Of the 29 sampling efforts by Connolly on the Wind River, only six had densities lower than $10 \mathrm{fish} / 100 \mathrm{~m}^{2}$. Although the presence of steelhead juveniles may be a key factor in the higher densities observed in the Wind River basin, steelhead are present in Outlet Creek and juveniles can easily migrate into Outlet Creek from the Klickitat River; yet the density of $O$. mykiss there was considerably less than observed during most of the Wind River sampling events. The only area we sampled that might approach Wind River densities would be the mainstem Klickitat River below Castile Falls. Both $O$. mykiss and juvenile chinook salmon were too numerous (100's) to count in such a wide river.

\section{Limiting Factors}

If our preliminary assessment that bull trout are not able to negotiate the lowest falls on the West Fork Klickitat River is correct, the greatest limiting factor for bull trout in that basin is likely the small amount of available habitat that results in a low total abundance, and the isolation of the population. Many of the streams are fragmented by natural falls which are partial or complete barriers to upstream fish movement. There are only 17.4 miles of stream to support bull trout, including 6.2 miles of Fish Lake Stream where bull trout have never been documented, and the 4 miles downstream of falls \#2 on the West Fork Klickitat River (which is likely a barrier to upstream migration). An additional 2 or 3 miles of stream in the unnamed tributary to Fish Lake Stream and in unnamed tributary \#1 to Two Lakes Stream might provide additional habitat.

Of the available habitat, high densities were found only in Trappers Creek, Clearwater Creek, and the unnamed tributary to Fish Lake Stream, a combined distance of only 4.1 miles. This small area is the critical habitat for this population. To date, we have not been able to show that any migrations occur in this population, especially for fluvial fish. Rieman and McIntyre (1995) synthesized the work of others on small, isolated populations and suggested they were less 
likely to persist because (1) small populations face higher risk of extinction through demographic and environmental stochasticity and Allee effects; and (2) isolated populations have a lower probability of demographic support or recolonization through dispersal from surrounding populations. Because no fish inhabit Clearwater Creek upstream of the falls, it is a good potential area for introducing bull trout and expanding the population. If issues surrounding other species (amphibians, invertebrates, etc...) can be overcome, introduction into Clearwater Creek may be the most efficient activity for enhancing the West Fork Klickitat River population.

Exotic species have been shown to be a detriment to the survival and recovery of bull trout. Brook trout are present throughout the entire Klickitat River drainage and may be negatively impacting bull trout in the West Fork Klickitat River drainage. Donald and Alger (1992) documented that introduced lake trout (Salvelinus namaycush) can displace and eliminate native bull trout in lacustrine environments. Markle (1992) studied bull trout, brook trout, and resulting bull/brook hybrids in Oregon and found that some small populations of bull trout are seriously threatened by the presence of brook trout. Hybridization results in offspring that are nearly always sterile, eventually eliminating bull trout from a system (Leary et al. 1993).

Surprisingly, we were not able to confirm any hybrids in 2001. Removal or reductions of brook trout might be beneficial for maintaining the bull trout population. However, brook trout removal would be extremely difficult in this system.

Logging and road building activities can threaten bull trout populations both within and downstream of managed areas through increased sediment production and delivery to streams, reduced streamside canopy closure, increased stream temperatures, and reduced woody debris recruitment (Chamberlain et al. 1991; Furniss et al. 1991). Extensive timber harvest and road building has occurred throughout the Klickitat River basin (except for the Primitive Area) and may have resulted in some of these impacts.

\section{ACKNOWLEDGMENTS}

This project was funded by the Bonneville Power Administration. We thank Ron Morinaka for his guidance and assistance with funding. We wish to thank those people that assisted with this project including, installation of a screw trap, electroshocking, night snorkeling, and general reconnaissance. Bill Sharp of the Yakama Nation was instrumental in providing people to assist with the project and assisting with necessary permits. The following people from the Yakama Nation installed a screw trap on the West Fork Klickitat River to assist with this assessment of bull trout: Sandy Pinkham, Isadore Honanie, Greg Strom, Roger Stahi, William Wesley, and Noel Eagleheart. We appreciate their experience and hard work.

We also wish to thank Bryan Keithly, Chris Tyndall, Raylene, and Ed Morgan of the Bureau of Indian Affairs office in Glenwood, for their hospitality and for providing accommodations during our work on the Klickitat and White Salmon river basins. We also thank Frank Backus and Jon Cole of SDS Lumber Company for providing permission to survey Spring Creek on SDS property near Northwestern Lake and other SDS property. We also appreciate permission granted by Pat Morris to access SDS property through his land. Nate Putnam of 
Campbell Corporation and Eric Keller of Boise Cascade provided keys to access streams on company property.

We thank Dan Rawding, John Weinheimer, Jim Byrne, and Craig Burley who provided valuable guidance and advice.

\section{LITERATURE CITED}

Adams, S.B., and T.C. Bjornn. 1997. Bull trout distributions related to temperature regimes in four central Idaho streams. Pages 371-380 in W.C. Mackay, M.K. Brewin, and M. Monita, editors. Friends of the bull trout conference proceedings. Bull Trout Task Force (Alberta), c/o Trout Unlimited Canada, Calgary.

Brun, C.V., and R.D. Dodson. 2001. Bull trout distribution and abundance in the waters on and bordering the Warm Springs Reservation. Project Number 199405400. Confederated Tribes of the Warm Springs Reservation. 2000 Annual Report. Prepared for U.S. Department of Energy, Bonneville Power Administration, Portland, Oregon.

Buchanan, D.V., M.L. Hanson, and R.M. Hooton. 1997. Status of Oregon's bull trout. Oregon Department of Fish and Wildlife. Portland, Oregon.

Byrne, J., R. McPeak, and B. McNamara. 2001. Bull Trout Population Assessment in the Columbia River Gorge. Washington Department of Fish and Wildlife. BPA Contract \#00000651-00001. Prepared for U.S. Department of Energy, Bonneville Power Administration, Portland, Oregon.

Chamberlain, T.W., R.D. Harr, and F.H. Everest. 1991. Timber harvesting, silviculture, and watershed processes. American Fisheries Society Special Publication 19:181-206.

Cline, D.R. 1976. Reconnaissance of the water resources of the upper Klickitat River basin, Yakima Indian Reservation, Washington. Open-File Report 75-518. United States Department of the Interior, Geological Survey. Tacoma, Washington.

Donald, D.B., and D.J. Alger. 1992. Geographic distribution, species displacement, and niche overlap for lake trout and bull trout in mountain lakes. Canadian Journal of Zoology 71:238-247.

Dunham, J.B., and B.E. Rieman. 1999. Metapopulation structure of bull trout: influences of physical, biotic, and geometrical landscape characteristics. Ecological Applications 9(2): 642-655.

Fraley, J.J., and B.B. Shepard. 1989. Life history, ecology and population status of migratory bull trout (Salvelinus confluentus) in the Flathead Lake river system, Montana. Northwest Science 63:133-143. 
Furniss, M.J., T.D. Roelofs, and C.S. Yee. 1991. Road construction and maintenance. American Fisheries Society Special Publication 19:297-324.

Hemmingsen, A.R., S.L. Gunckel, and P.J. Howell. 2001. Bull trout life history, genetics, habitat needs, and limiting factors in central and northeast Oregon. 1999 Annual Report. Prepared for U.S. Department of Energy, Bonneville Power Administration. Project Number 199405400. Oregon Department of Fish and Wildlife, Portland.

Kostow, K. 1995. Biennial report on the status of wild fish in Oregon. Oregon Department of Fish and Wildlife. Portland, Oregon.

Leary, R.F., F.W. Allendorf, and S.H. Forbes. 1993. Conservation genetics of bull trout in the Columbia and Klamath River drainages. Conservation Biology 7:856-865.

Markle, D.F. 1992. Evidence of bull trout x brook trout hybrids in Oregon. Pages 58-67 in P.J. Howell and D.V. Buchanan, editors. Proceedings of the Gearhart Mountain bull trout workshop. Oregon Chapter of the American Fisheries Society, Corvallis.

Northwest Power Planning Council. 2000. Draft. Klickitat Subbasin Summary. Prepared for the Northwest Power Planning Council. Columbia Basin Fish and Wildlife Authority. Portland, Oregon.

Peterson, J., J. Dunham, P. Howell, R. Thurow, and S. Bonar. 2002. Protocol for detecting bull trout presence. Report to Western Division American Fisheries Society. American Fisheries Society, Bethesda, Maryland.

Reynolds, J.B. 1996. Electrofishing. Pages 221-254 in B.R. Murphy and D.W. Willis, editors. Fisheries Techniques. American Fisheries Society, Bethesda, Maryland.

Riehle, M., W. Weber, A.M. Stuart, S.L. Thiesfeld, and D.E. Ratliff. 1997. Progress report of the multi-agency study of bull trout in the Metolius River system, Oregon. Pages 137-144 in W.C. Mackay, M.K. Brewin, and M. Monita, editors. Friends of the bull trout conference proceedings. Bull Trout Task Force (Alberta), c/o Trout Unlimited Canada, Calgary.

Rieman, B.E., and J.D. McIntyre. 1993. Demographic and habitat requirements for conservation of bull trout. General Technical Report INT-302, USDA Forest Service, Intermountain Research Station, Ogden, Utah.

Rieman, B.E., and J.D. McIntyre. 1995. Occurrence of bull trout in naturally fragmented patches of varied size. Transactions of the American Fisheries Society 124:285-296.

Sexauer, H.M., and P.W. James. 1997. Microhabitat use by juvenile bull trout in four streams located in the eastern Cascades, Washington. Pages 361-370 in W.C. Mackay, M.K. 
Brewin, and M. Monita, editors. Friends of the bull trout conference proceedings. Bull Trout Task Force (Alberta), c/o Trout Unlimited Canada, Calgary.

Spruell P., and F.W. Allendorf. 1997. Nuclear DNA analysis of Oregon bull trout. Oregon Department of Fish and Wildlife Report 97/5. Portland, Oregon.

Thiesfeld, S.L., A.M. Stuart, D.E. Ratliff, and B.D. Lampman. 1996. Migration patterns of adult bull trout in the Metolius River and Lake Billy Chinook, Oregon. Information Report 961. Oregon Department of Fish and Wildlife, Portland.

Thiesfeld, S.L., J.C. Kern, A.R. Dale, M.W. Chilcote, and M.A. Buckman. 1999. Lake Billy Chinook sockeye salmon and kokanee research study 1996-1998, contract completion report. Prepared for Portland General Electric. Oregon Department of Fish and Wildlife. Portland.

Washington Department of Fish and Wildlife. 1998. Washington State salmonid stock inventory: Bull Trout/Dolly Varden. 600 Capitol Way North, Olympia, Washington 98501. 
Appendix A. Habitat measurements from streams in the Klickitat and White Salmon river basins, 2001.

\section{APPENDICES}

Appendix A. Habitat measurements from streams in the Klickitat and White Salmon river basins, 2001.

\begin{tabular}{|c|c|c|c|c|c|c|c|c|c|c|c|c|c|c|c|c|c|}
\hline DATE & STREAM & TRIBUTARY OF & BASIN & 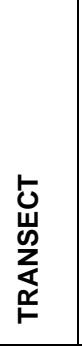 & $\begin{array}{l}\text { I } \\
\text { J } \\
\text { J }\end{array}$ & $\sum_{W}^{0}$ & 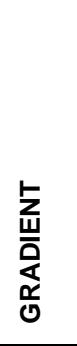 & 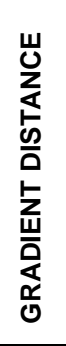 & $\sum_{3}^{0}$ & $\begin{array}{l}\bar{I} \\
\frac{1}{3} \\
\frac{5}{3}\end{array}$ & $\begin{array}{l}\mathbf{N} \\
\mathbf{I} \\
\stackrel{5}{\mathbf{n}} \\
\mathbf{3}\end{array}$ & 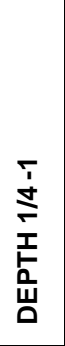 & 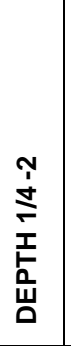 & 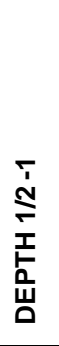 & 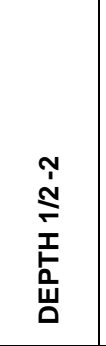 & 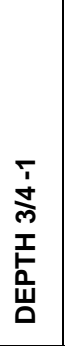 & 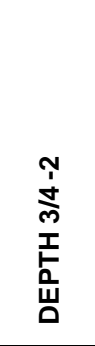 \\
\hline 16-Jul-01 & W. Fork Klickitat & Klickitat & Klickitat & 1 & 100 & 9.5 & 2.5 & 46 & 0 & 16 & 11.1 & 64 & 5 & 11 & 73 & 59 & 76 \\
\hline 16-Jul-01 & Trappers & Little Muddy & Klickitat & 1 & 100 & 6.5 & 5 & 23 & 71 & 3.7 & 2.6 & 15 & 8 & 18 & 16 & 4 & 8 \\
\hline 16-Jul-01 & Trappers & Little Muddy & Klickitat & 2 & 100 & 6.5 & 1 & 100 & 55 & 4.1 & 4.1 & 23 & 16 & 23 & 14 & 20 & 28 \\
\hline 17-Jul-01 & W. Fork Klickitat & Klickitat & Klickitat & 2 & 100 & 9.5 & 2.25 & 100 & 30 & 20 & 13 & 15 & & 52 & & 63 & \\
\hline 17-Jul-01 & Klickitat & Columbia & Klickitat & 1 & 100 & 11.5 & 0.75 & 100 & 4 & 28.3 & 19.7 & 32 & 21 & 33 & 44 & 16 & 57 \\
\hline 17-Jul-01 & Klickitat & Columbia & Klickitat & 2 & 100 & 11.5 & 0.38 & 100 & 2 & 19.7 & 13 & 21 & 71 & 44 & $100+$ & 57 & $100+$ \\
\hline 23-Jul-01 & Trappers & Little Muddy & Klickitat & 3 & 100 & 9.5 & 4.75 & 47 & 29 & 1.8 & 3.4 & 10 & 10 & 11 & 11 & 7 & 6 \\
\hline 23-Jul-01 & Trappers & Little Muddy & Klickitat & 4 & 100 & 9.5 & 2 & 27 & 21 & 3.8 & 3 & 4 & 21 & 17 & 21 & 7 & 24 \\
\hline 23-Jul-01 & W. Fork Klickitat & Klickitat & Klickitat & 3 & 100 & 11.5 & 1.25 & 100 & 32 & 18.6 & 17.1 & 56 & 35 & 8 & 76 & 54 & 44 \\
\hline 30-Jul-01 & Clearwater & Little Muddy & Klickitat & 1 & 100 & 7 & 4 & 73 & 84 & 7.5 & 12.2 & 35 & 40 & 38 & 32 & 19 & 22 \\
\hline 31-Jul-01 & Klickitat & Columbia & Klickitat & 3 & 100 & 13 & 0.5 & 100 & 22 & 11.2 & 10.3 & 56 & 46 & 36 & 46 & 35 & 27 \\
\hline 31-Jul-01 & Klickitat & Columbia & Klickitat & 4 & 100 & 12.8 & 1 & 100 & 9 & 11.2 & 6.7 & 15 & 67 & 20 & 86 & 24 & 39 \\
\hline 31-Jul-01 & Klickitat & Columbia & Klickitat & 5 & 100 & 12.8 & 0.9 & 100 & 13 & 6.6 & 7.3 & 10 & 20 & 27 & 19 & 30 & 23 \\
\hline 27-Aug-01 & Unnamed \#1 & Klickitat & Klickitat & 1 & 80.5 & 6 & 2.75 & 80 & 17 & 2.1 & 2.1 & 7 & 13 & 6 & 9 & 7 & 9 \\
\hline 27-Aug-01 & Klickitat & Columbia & Klickitat & 6 & 100 & 11.5 & 2.5 & 100 & 61 & 5.7 & 9.7 & 0 & 1 & 17 & 0 & 32 & 12 \\
\hline 27-Aug-01 & Klickitat & Columbia & Klickitat & 7 & 100 & 11.5 & 3 & 50 & 29 & 9.7 & 5 & 1 & 12 & 0 & 25 & 12 & 14 \\
\hline 27-Aug-01 & Klickitat & Columbia & Klickitat & 8 & 100 & 11.5 & 2.5 & 50 & 41 & 5 & 7.6 & 12 & 6 & 25 & 0 & 14 & 20 \\
\hline 27-Aug-01 & Klickitat & Columbia & Klickitat & 9 & 49 & 11.5 & 2 & 50 & 13 & 7.6 & 9.1 & 6 & 30 & 0 & 42 & 20 & 21 \\
\hline 25-Sep-01 & Two Lakes & Fish Lake & Klickitat & 1 & 100 & 5 & 3.4 & 100 & 24 & 8.9 & 16 & 13 & 32 & 7 & 17 & 24 & 26 \\
\hline 25-Sep-01 & Two Lakes & Fish Lake & Klickitat & 2 & 100 & 5 & 5 & 100 & 29 & 16 & 14.4 & 32 & 0 & 17 & 52 & 26 & 28 \\
\hline 8-Oct-01 & Unnamed \#1 & Two Lakes & Klickitat & 1 & 100 & 4.5 & 2 & 52 & 89 & 8 & 10 & 43 & 0 & 16 & 39 & 3 & 32 \\
\hline 8-Oct-01 & Unnamed \#1 & Two Lakes & Klickitat & 2 & 100 & 4.5 & 2.25 & 47 & 100 & 10 & 13.5 & 0 & 0 & 39 & 12 & 32 & 46 \\
\hline 8-Oct-01 & Unnamed \#1 & Unnamed Trib \# 1 of Two Lakes & Klickitat & 1 & 100 & 4 & & & 83 & 3.8 & 3.3 & 21 & 18 & 17 & 11 & 13 & 5 \\
\hline 9-Oct-01 & Outlet & Klickitat & Klickitat & 1 & 100 & 8.5 & 5.25 & 100 & 4 & 7.2 & 14.2 & 50 & 49 & 0 & 44 & 20 & 93 \\
\hline 9-Oct-01 & Outlet & Klickitat & Klickitat & 2 & 100 & 8.5 & 4.75 & 86 & 0 & 14.2 & 10.7 & 49 & 61 & 44 & 0 & 93 & 41 \\
\hline 26-Jun-01 & Middle Fork Buck & White Salmon & White Salmon & 1 & 100 & 8.3 & 12.5 & 74 & 14 & 6.1 & 3.9 & 60 & 0 & 17 & 16 & 0 & 9 \\
\hline 26-Jun-01 & Buck & White Salmon & White Salmon & 1 & 100 & 12 & 3 & 100 & 10 & 7 & 5 & 23 & 21 & 20 & 37 & 16 & 18 \\
\hline 26-Jun-01 & Buck & White Salmon & White Salmon & 2 & 100 & 10.5 & 4.5 & 75 & 13 & 11 & 7 & 0 & 2 & 6 & 30 & 10 & 11 \\
\hline 26-Jun-01 & Buck & White Salmon & White Salmon & 3 & 100 & 10.5 & 3.75 & 100 & 9 & 7 & 6 & 2 & 10 & 30 & 21 & 11 & 5 \\
\hline
\end{tabular}


Appendix A. Habitat measurements from streams in the Klickitat and White Salmon river basins, 2001.

\begin{tabular}{|c|c|c|c|c|c|c|c|c|c|c|c|c|c|c|c|c|c|}
\hline 26-Jun-01 & Meadow & Trout Lake & \begin{tabular}{|l|} 
White Salmon \\
\end{tabular} & 1 & 100 & 11 & 0.5 & 30 & 13 & 9 & 10 & 110 & 34 & 80 & 85 & 69 & 86 \\
\hline 26-Jun-01 & Meadow & Trout Lake & White Salmon & 2 & 100 & 11 & 0.5 & 35 & 9 & 10 & 9.5 & 34 & 18 & 85 & 101 & 86 & 64 \\
\hline 27-Jun-01 & Meadow & Trout Lake & White Salmon & 3 & 100 & 9 & 2.5 & 52 & & 3 & 18 & 19 & 2 & 17 & 0 & 12 & 4 \\
\hline 2-Jul-01 & Lost & None & None & 1 & 100 & 8.5 & 1.25 & 100 & 22 & 8.6 & 5.7 & 80 & 17 & 3 & 29 & 20 & 39 \\
\hline 2-Jul-01 & Lost & None & None & 2 & 100 & 8.5 & 1.25 & 90 & 9 & 5.7 & 10 & 17 & 38 & 29 & 22 & 39 & 0 \\
\hline 2-Jul-01 & Little Goose & Trout Lake & White Salmon & 1 & 100 & 9.5 & 2 & 61 & 22 & 10 & 5 & 8 & 3 & 15 & 14 & 17 & 21 \\
\hline 9-Jul-01 & Smokey & Little Goose & White Salmon & 1 & 100 & 14 & 4.5 & 56 & 21 & 3.2 & 1.7 & 22 & 2 & 25 & 3 & 27 & 0 \\
\hline 9-Jul-01 & Cultus & Trout Lake & White Salmon & 1 & 100 & 14 & 5 & 78 & 7 & 11.4 & 4.1 & 0 & 23 & 20 & 0 & 26 & 34 \\
\hline 9-Jul-01 & Cultus & Trout Lake & White Salmon & 2 & 100 & 14 & 5 & 100 & 5 & 4.1 & 4.4 & 23 & 22 & 0 & 25 & 34 & 0 \\
\hline 10-Jul-01 & Mosquito & Trout Lake & White Salmon & 1 & 100 & 7 & 1 & 20 & 28 & 2.5 & 2.2 & 12 & 10 & 6 & 12 & 10 & 14 \\
\hline 10-Jul-01 & Mosquito & Trout Lake & White Salmon & 2 & 100 & 7 & 7.25 & 46 & 28 & 2.5 & 1.9 & 13 & 11 & 7 & 16 & 14 & 13 \\
\hline 10-Jul-01 & Cultus & Trout Lake & White Salmon & 3 & 100 & 10.5 & 1.75 & 75 & 3 & 2.7 & 3.6 & 20 & 8 & 24 & 12 & 20 & 0 \\
\hline 10-Jul-01 & Cultus & Trout Lake & White Salmon & 4 & 100 & 10.5 & 2 & 30 & 12 & 3.6 & 1.8 & 8 & 29 & 12 & 30 & 0 & 12 \\
\hline 13-Aug-01 & Spring & White Salmon & White Salmon & 1 & 100 & 11 & 1.2 & 68 & 23 & 4 & 6 & 39 & 28 & 31 & 37 & 12 & 21 \\
\hline 13-Aug-01 & Spring & White Salmon & White Salmon & 2 & 100 & 11 & 1.5 & 88 & 12 & 4.6 & 2.4 & 16 & 29 & 23 & 29 & 28 & 14 \\
\hline 13-Aug-01 & Spring & White Salmon & White Salmon & 3 & 100 & 11 & 1 & 68 & 6 & 3 & 3.4 & 37 & 36 & 39 & 69 & 24 & 43 \\
\hline
\end{tabular}

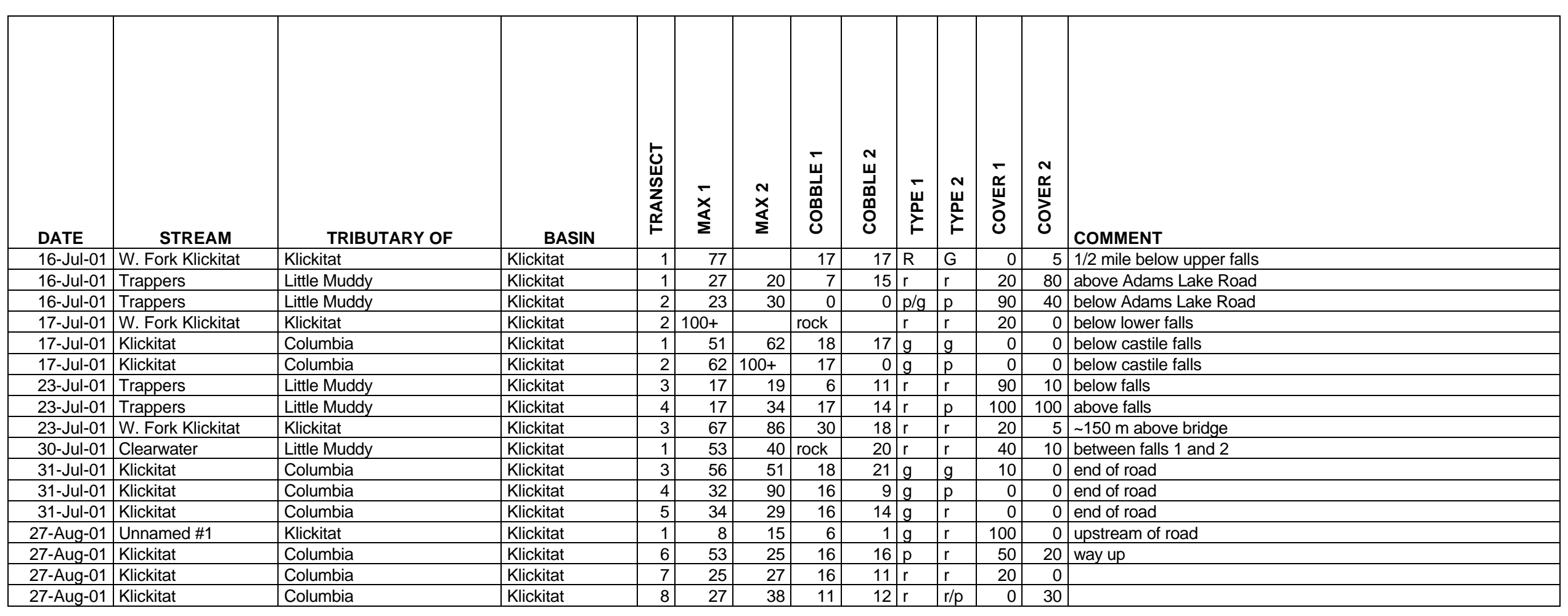


Appendix A. Habitat measurements from streams in the Klickitat and White Salmon river basins, 2001.

\begin{tabular}{|c|c|c|c|c|c|c|c|c|c|c|c|c|c|}
\hline 27-Aug-01 & Klickitat & Columbia & Klickitat & 9 & 38 & 47 & 12 & 13 & $r / p$ & $p$ & 30 & 5 & \\
\hline 25-Sep-01 & Two Lakes & Fish Lake & Klickitat & 1 & 37 & 39 & rock & rock & $g$ & $g$ & 70 & 5 & below falls \\
\hline 25-Sep-01 & Two Lakes & Fish Lake & Klickitat & 2 & 39 & 56 & rock & 5 & $g$ & $p$ & 5 & 60 & below falls \\
\hline 8-Oct-01 & Unnamed \#1 & Two Lakes & Klickitat & 1 & 43 & 49 & 7 & 2 & $r$ & $r$ & 15 & 25 & trib just upstream from confluence with fish lake stream \\
\hline 8-Oct-01 & Unnamed \#1 & Two Lakes & Klickitat & 2 & 49 & 70 & 2 & 4 & $r$ & $r$ & 25 & 80 & trib just upstream from confluence with fish lake stream \\
\hline 8-Oct-01 & Unnamed \#1 & Unnamed Trib \# 1 of Two Lakes & Klickitat & 1 & 28 & 21 & 0 & 3 & $p$ & $\mathrm{r}$ & 97 & 80 & \\
\hline 9-Oct-01 & Outlet & Klickitat & Klickitat & 1 & 85 & 99 & 32 & 19 & $\mathrm{r}$ & $\mathrm{r}$ & 0 & 35 & \\
\hline 9-Oct-01 & Outlet & Klickitat & Klickitat & 2 & 99 & 112 & 19 & 23 & $r$ & $\mathrm{r}$ & 35 & 20 & \\
\hline 26-Jun-01 & Middle Fork Buck & White Salmon & White Salmon & 1 & 63 & 35 & 24 & 100 & $\mathrm{p}$ & $\mathrm{p}$ & 100 & 98 & \\
\hline 26-Jun-01 & Buck & White Salmon & White Salmon & 2 & 30 & 37 & 15 & 22 & $\mathrm{r}$ & $\mathrm{r}$ & 40 & 95 & above dam, just below confluence with south fork \\
\hline 26-Jun-01 & Buck & White Salmon & White Salmon & 3 & 37 & 36 & 22 & 17 & $r$ & $\mathrm{r}$ & 95 & 85 & above dam, just below confluence with south fork \\
\hline 26-Jun-01 & Meadow & Trout Lake & White Salmon & 1 & 112 & 91 & 0 & 0 & $p$ & $\mathrm{p}$ & 0 & 0 & above 88 road \\
\hline 26-Jun-01 & Meadow & Trout Lake & White Salmon & 2 & 91 & 102 & 0 & 0 & $p$ & $\mathrm{p}$ & 0 & 20 & above 88 road \\
\hline 27-Jun-01 & Meadow & Trout Lake & White Salmon & 3 & 26 & 22 & 17 & 7 & $r$ & $r$ & 0 & 80 & above 26 trail \\
\hline 2-Jul-01 & Lost & None & None & 1 & 21 & 42 & 21 & 17 & $r$ & $p$ & 10 & 2 & due east of 750 road \\
\hline 2-Jul-01 & Lost & None & None & 2 & 42 & 38 & 17 & 14 & $p$ & $r$ & 2 & 25 & due east of 750 road \\
\hline 2-Jul-01 & Little Goose & Trout Lake & White Salmon & 1 & 24 & 50 & 8 & 19 & $p$ & $r$ & 8 & 25 & above 883 \\
\hline 9-Jul-01 & Smokey & Little Goose & White Salmon & 1 & 30 & 11 & 0 & 18 & $\mathrm{p} / \mathrm{r}$ & $r$ & 20 & 100 & below 8831 road \\
\hline 10-Jul-01 & Mosquito & Trout Lake & White Salmon & 1 & 18 & 15 & 10 & 9 & $r$ & $r$ & 100 & 55 & 88 road \\
\hline 10-Jul-01 & Mosquito & Trout Lake & White Salmon & 2 & 15 & 18 & 10 & 15 & $r$ & $r$ & 60 & 80 & 8854 road \\
\hline 10-Jul-01 & Cultus & Trout Lake & White Salmon & 3 & 25 & 23 & 16 & 9 & $r$ & $r$ & 100 & 10 & 24 road \\
\hline 10-Jul-01 & Cultus & Trout Lake & White Salmon & 4 & 23 & 30 & 9 & 10 & $r$ & $r$ & 10 & 95 & 24 road \\
\hline 13-Aug-01 & Spring & White Salmon & White Salmon & 1 & 43 & 37 & 7 & 8 & $g$ & $g$ & 98 & 20 & below Spring Creek Road \\
\hline 13-Aug-01 & Spring & White Salmon & White Salmon & 2 & 28 & 31 & 4 & 9 & $\mathrm{~g}$ & $r$ & 30 & 30 & below Spring Creek Road \\
\hline 13-Aug-01 & Spring & White Salmon & White Salmon & 3 & 39 & 85 & 7 & 6 & $\mathrm{~g}$ & $p$ & 90 & 0 & below Spring Creek Road \\
\hline
\end{tabular}


Appendix B. Snorkel counts from streams in the Klickitat and White Salmon river basins, 2001.

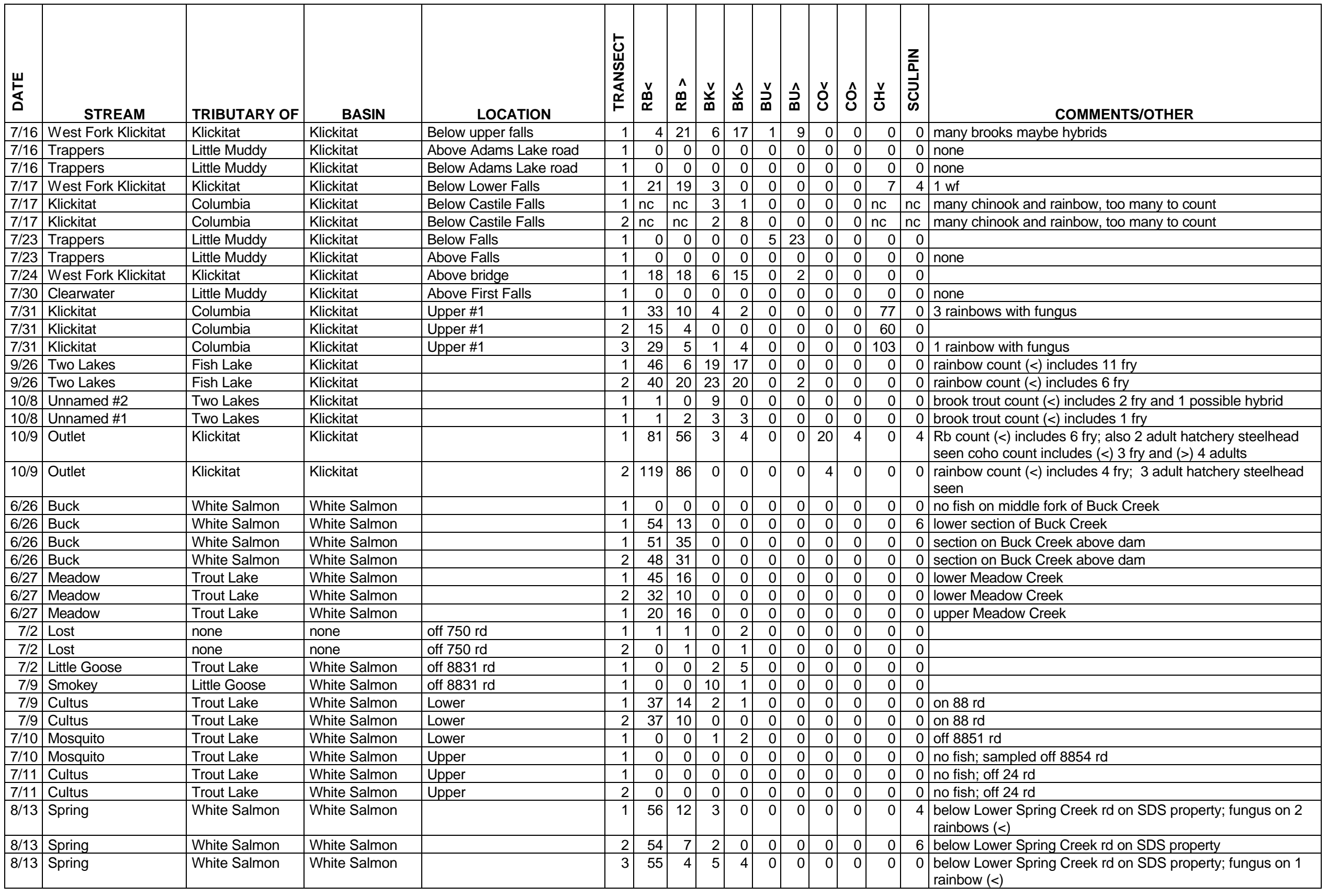


Appendix C. Electroshock data from streams in the Klickitat and White Salmon river basins, 2001.

\begin{tabular}{|c|c|c|c|c|c|c|c|}
\hline Date & Stream & Tributary of & Basin & 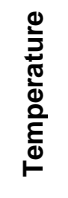 & 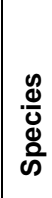 & 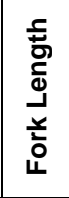 & Comments \\
\hline $8 / 29$ & Unnamed \#1 & Cave & White Salmon & 5.8 & $\mathrm{Bk}$ & 113 & below 707 road \\
\hline $8 / 29$ & Unnamed \#1 & Cave & White Salmon & 5.8 & $\mathrm{Bk}$ & 89 & below 707 road \\
\hline $8 / 29$ & Unnamed \#1 & Cave & White Salmon & 5.8 & $\mathrm{Bk}$ & 151 & below 707 road \\
\hline $8 / 29$ & Unnamed \#1 & Cave & White Salmon & 5.8 & $\mathrm{Bk}$ & 59 & below 707 road \\
\hline $8 / 29$ & Unnamed \#1 & Cave & White Salmon & 5.8 & $\mathrm{Bk}$ & 89 & below 707 road \\
\hline $8 / 29$ & Unnamed \#1 & Cave & White Salmon & 5.8 & $\mathrm{Bk}$ & 55 & below 707 road \\
\hline $8 / 29$ & Unnamed \#1 & Cave & White Salmon & 5.8 & Bk & 82 & below 707 road \\
\hline $8 / 29$ & Unnamed \#1 & Cave & \begin{tabular}{|l|} 
White Salmon \\
\end{tabular} & 5.8 & Bk & 105 & below 707 road \\
\hline $8 / 29$ & Unnamed \#1 & Cave & White Salmon & 5.8 & $\mathrm{Bk}$ & 83 & below 707 road \\
\hline $8 / 29$ & Unnamed \#1 & Cave & White Salmon & 5.8 & $\mathrm{Bk}$ & 92 & below 707 road \\
\hline $8 / 29$ & Unnamed \#1 & Cave & White Salmon & 5.8 & Bk & 50 & below 707 road \\
\hline $8 / 29$ & Unnamed \#1 & Cave & White Salmon & 5.8 & $\mathrm{Bk}$ & 51 & below 707 road \\
\hline $8 / 29$ & Unnamed \#1 & Cave & White Salmon & 5.8 & $\mathrm{Bk}$ & 54 & below 707 road \\
\hline $8 / 29$ & Unnamed \#2 & Cave & White Salmon & 7.2 & & & off of 041 road, sds property, no fish captured \\
\hline $8 / 29$ & Beaver & Cave & White Salmon & 13.3 & $\mathrm{Bk}$ & 145 & above 8631 road \\
\hline $8 / 29$ & Beaver & Cave & White Salmon & 13.3 & $\mathrm{Bk}$ & 147 & above 8631 road \\
\hline $8 / 29$ & Beaver & Cave & White Salmon & 13.3 & $\mathrm{Bk}$ & 156 & above 8631 road \\
\hline $8 / 29$ & Beaver & Cave & White Salmon & 13.3 & $\mathrm{Bk}$ & 49 & above 8631 road \\
\hline $8 / 29$ & Beaver & Cave & White Salmon & 13.3 & $\mathrm{Bk}$ & 54 & above 8631 road \\
\hline $8 / 29$ & Beaver & Cave & White Salmon & 13.3 & $\mathrm{Bk}$ & 42 & above 8631 road \\
\hline $8 / 29$ & Beaver & Cave & White Salmon & 13.3 & Bk & 49 & above 8631 road \\
\hline $8 / 29$ & Beaver & Cave & White Salmon & 13.3 & Bk & 49 & above 8631 road \\
\hline $8 / 29$ & Beaver & Cave & White Salmon & 13.3 & $\mathrm{Bk}$ & 42 & above 8631 road \\
\hline $8 / 29$ & Beaver & Cave & White Salmon & 13.3 & $\mathrm{Bk}$ & 54 & above 8631 road \\
\hline $8 / 29$ & Beaver & Cave & White Salmon & 13.3 & $\mathrm{Bk}$ & 143 & above 8631 road \\
\hline $8 / 29$ & Beaver & Cave & White Salmon & 13.3 & $\mathrm{Bk}$ & 105 & above 8631 road \\
\hline $8 / 29$ & Beaver & Cave & White Salmon & 13.3 & $\mathrm{Bk}$ & 102 & above 8631 road \\
\hline $8 / 29$ & Beaver & Cave & White Salmon & 13.3 & $\mathrm{Bk}$ & 62 & above 8631 road \\
\hline $8 / 29$ & Beaver & Cave & White Salmon & 13.3 & $\mathrm{Bk}$ & 53 & above 8631 road \\
\hline $8 / 29$ & Beaver & Cave & White Salmon & 13.3 & $\mathrm{Bk}$ & 52 & above 8631 road \\
\hline $8 / 29$ & Beaver & Cave & White Salmon & 13.3 & $\mathrm{Bk}$ & 39 & above 8631 road \\
\hline $8 / 29$ & Beaver & Cave & White Salmon & 13.3 & $\mathrm{Bk}$ & 147 & above 8631 road \\
\hline $8 / 29$ & Beaver & Cave & White Salmon & 13.3 & $\mathrm{Bk}$ & 53 & above 8631 road \\
\hline $8 / 29$ & Beaver & Cave & White Salmon & 13.3 & Bk & 45 & above 8631 road \\
\hline $8 / 29$ & Beaver & Cave & White Salmon & 13.3 & $\mathrm{Bk}$ & 52 & above 8631 road \\
\hline $9 / 20$ & Mill & White Salmon & White Salmon & 12 & $\mathrm{Rb}$ & 134 & above horse ranch \\
\hline $9 / 20$ & Mill & White Salmon & White Salmon & 12 & $\mathrm{Rb}$ & 110 & above horse ranch \\
\hline $9 / 20$ & Mill & White Salmon & White Salmon & 12 & $\mathrm{Rb}$ & 120 & above horse ranch \\
\hline $9 / 20$ & Mill & White Salmon & White Salmon & 12 & $\mathrm{Rb}$ & 115 & above horse ranch \\
\hline $9 / 20$ & Mill & White Salmon & White Salmon & 12 & $\mathrm{Rb}$ & 112 & above horse ranch \\
\hline $9 / 20$ & Mill & White Salmon & White Salmon & 12 & $\mathrm{Rb}$ & 115 & above horse ranch \\
\hline $9 / 20$ & Mill & White Salmon & White Salmon & 12 & $\mathrm{Rb}$ & 110 & above horse ranch \\
\hline $9 / 20$ & Mill & White Salmon & White Salmon & 12 & $\mathrm{Rb}$ & 87 & above horse ranch \\
\hline $9 / 20$ & Mill & White Salmon & White Salmon & 12 & $\mathrm{Rb}$ & 84 & above horse ranch \\
\hline $9 / 20$ & Mill & White Salmon & White Salmon & 12 & $\mathrm{Rb}$ & 109 & above horse ranch \\
\hline $9 / 20$ & Mill & White Salmon & White Salmon & 12 & $\mathrm{Rb}$ & 114 & above horse ranch \\
\hline $9 / 20$ & Mill & White Salmon & White Salmon & 12 & $\mathrm{Rb}$ & 48 & above horse ranch \\
\hline $9 / 20$ & Mill & White Salmon & White Salmon & 12 & $\mathrm{Rb}$ & 43 & above horse ranch \\
\hline $9 / 20$ & Mill & White Salmon & White Salmon & 12 & $\mathrm{Rb}$ & 130 & above horse ranch \\
\hline $9 / 20$ & Mill & White Salmon & White Salmon & 12 & $\mathrm{Rb}$ & 119 & above horse ranch \\
\hline $9 / 20$ & Mill & White Salmon & \begin{tabular}{|l} 
White Salmon \\
\end{tabular} & 12 & $\mathrm{Rb}$ & 113 & above horse ranch \\
\hline $9 / 20$ & Mill & White Salmon & White Salmon & 12 & $\mathrm{Rb}$ & 115 & above horse ranch \\
\hline $9 / 20$ & Mill & White Salmon & White Salmon & 12 & $\mathrm{Rb}$ & 75 & above horse ranch \\
\hline $9 / 20$ & Mill & White Salmon & White Salmon & 12 & $\mathrm{Rb}$ & 89 & above horse ranch \\
\hline $9 / 20$ & Mill & White Salmon & White Salmon & 12 & $\mathrm{Rb}$ & 90 & above horse ranch \\
\hline $9 / 20$ & Mill & White Salmon & White Salmon & 12 & $\mathrm{Rb}$ & 47 & above horse ranch \\
\hline $9 / 20$ & Mill & White Salmon & White Salmon & 12 & $\mathrm{Rb}$ & 137 & above horse ranch \\
\hline $9 / 20$ & Mill & White Salmon & White Salmon & 12 & $\mathrm{Rb}$ & 128 & above horse ranch \\
\hline $9 / 20$ & Mill & White Salmon & White Salmon & 12 & $\mathrm{Rb}$ & 43 & above horse ranch \\
\hline $9 / 20$ & Mill & White Salmon & White Salmon & 12 & $\mathrm{Rb}$ & 95 & above horse ranch \\
\hline $9 / 20$ & Mill & White Salmon & White Salmon & 12 & $\mathrm{Rb}$ & 93 & above horse ranch \\
\hline $9 / 20$ & Mill & White Salmon & \begin{tabular}{|l} 
White Salmon \\
\end{tabular} & 12 & $\mathrm{Rb}$ & 87 & above horse ranch \\
\hline
\end{tabular}




\begin{tabular}{|c|c|c|c|c|c|c|c|}
\hline $9 / 20$ & Mill & White Salmon & White Salmon & 12 & $\mathrm{Rb}$ & 52 & above horse ranch \\
\hline $9 / 20$ & Mill & White Salmon & White Salmon & 12 & $\mathrm{Rb}$ & 43 & above horse ranch \\
\hline $9 / 20$ & Mill & White Salmon & White Salmon & 12 & $\mathrm{Rb}$ & 133 & above horse ranch \\
\hline $9 / 20$ & Mill & White Salmon & White Salmon & 12 & $\mathrm{Rb}$ & 147 & above horse ranch \\
\hline $9 / 20$ & Mill & White Salmon & White Salmon & 12 & $\mathrm{Rb}$ & 119 & above horse ranch \\
\hline $9 / 20$ & Mill & White Salmon & White Salmon & 12 & $\mathrm{Rb}$ & 110 & above horse ranch \\
\hline $9 / 20$ & Mill & White Salmon & White Salmon & 12 & $\mathrm{Rb}$ & 115 & above horse ranch \\
\hline $9 / 20$ & Mill & White Salmon & White Salmon & 12 & $\mathrm{Rb}$ & 113 & above horse ranch \\
\hline $9 / 20$ & Mill & White Salmon & White Salmon & 12 & $\mathrm{Rb}$ & 90 & above horse ranch \\
\hline $9 / 20$ & Mill & White Salmon & White Salmon & 12 & $\mathrm{Rb}$ & 78 & above horse ranch \\
\hline $9 / 20$ & Mill & White Salmon & White Salmon & 12 & $\mathrm{Rb}$ & 47 & above horse ranch \\
\hline $9 / 20$ & Mill & White Salmon & White Salmon & 12 & $\mathrm{Rb}$ & 47 & above horse ranch \\
\hline $9 / 20$ & Mill & White Salmon & White Salmon & 12 & $\mathrm{Rb}$ & 49 & above horse ranch \\
\hline $9 / 20$ & Mill & White Salmon & White Salmon & 12 & $\mathrm{Rb}$ & 132 & above horse ranch \\
\hline $9 / 20$ & Mill & White Salmon & White Salmon & 12 & $\mathrm{Rb}$ & 78 & above horse ranch \\
\hline $9 / 20$ & Mill & White Salmon & White Salmon & 12 & $\mathrm{Rb}$ & 78 & above horse ranch \\
\hline $9 / 20$ & Mill & White Salmon & White Salmon & 12 & $\mathrm{Rb}$ & 88 & above horse ranch \\
\hline $9 / 20$ & Mill & White Salmon & White Salmon & 12 & $\mathrm{Rb}$ & 80 & above horse ranch \\
\hline $9 / 20$ & Mill & White Salmon & White Salmon & 12 & $\mathrm{Rb}$ & 116 & above horse ranch \\
\hline $9 / 20$ & Mill & White Salmon & White Salmon & 12 & $\mathrm{Rb}$ & 94 & above horse ranch \\
\hline $9 / 20$ & Mill & White Salmon & White Salmon & 12 & $\mathrm{Rb}$ & 89 & above horse ranch \\
\hline $9 / 20$ & Mill & White Salmon & White Salmon & 12 & $\mathrm{Rb}$ & 92 & above horse ranch \\
\hline $9 / 20$ & Mill & White Salmon & White Salmon & 12 & $\mathrm{Rb}$ & 45 & above horse ranch \\
\hline $9 / 20$ & Mill & White Salmon & White Salmon & 12 & $\mathrm{Rb}$ & 82 & above horse ranch \\
\hline $9 / 20$ & Mill & White Salmon & White Salmon & 12 & $\mathrm{Rb}$ & 55 & above horse ranch \\
\hline $9 / 20$ & Mill & White Salmon & White Salmon & 12 & $\mathrm{Rb}$ & 47 & above horse ranch \\
\hline $9 / 20$ & Mill & White Salmon & White Salmon & 12 & $\mathrm{Rb}$ & 49 & above horse ranch \\
\hline 9/20 & Mill & White Salmon & White Salmon & 12 & $\mathrm{Rb}$ & 46 & above horse ranch \\
\hline $9 / 20$ & Mill & White Salmon & White Salmon & 12 & $\mathrm{Rb}$ & 137 & above horse ranch \\
\hline $9 / 20$ & Mill & White Salmon & White Salmon & 12 & $\mathrm{Rb}$ & 74 & above horse ranch \\
\hline $9 / 20$ & Mill & White Salmon & White Salmon & 12 & $\mathrm{Rb}$ & 83 & above horse ranch \\
\hline $9 / 20$ & Mill & White Salmon & White Salmon & 12 & $\mathrm{Rb}$ & 112 & above horse ranch \\
\hline $9 / 20$ & Mill & White Salmon & White Salmon & 12 & $\mathrm{Rb}$ & 98 & above horse ranch \\
\hline $9 / 20$ & Mill & White Salmon & White Salmon & 12 & $\mathrm{Rb}$ & 133 & above horse ranch \\
\hline $9 / 20$ & Mill & White Salmon & White Salmon & 12 & $\mathrm{Rb}$ & 112 & above horse ranch \\
\hline $9 / 20$ & Mill & White Salmon & White Salmon & 12 & $\mathrm{Rb}$ & 52 & above horse ranch \\
\hline $9 / 20$ & Mill & White Salmon & White Salmon & 12 & $\mathrm{Rb}$ & 82 & above horse ranch \\
\hline $9 / 20$ & Mill & White Salmon & White Salmon & 12 & $\mathrm{Rb}$ & 107 & above horse ranch \\
\hline $9 / 20$ & Mill & White Salmon & White Salmon & 12 & $\mathrm{Rb}$ & 119 & above horse ranch \\
\hline $9 / 20$ & Mill & White Salmon & White Salmon & 12 & $\mathrm{Rb}$ & 83 & above horse ranch \\
\hline $9 / 20$ & Mill & White Salmon & White Salmon & 12 & $\mathrm{Rb}$ & 78 & above horse ranch \\
\hline $9 / 20$ & Mill & White Salmon & White Salmon & 12 & $\mathrm{Rb}$ & 86 & above horse ranch \\
\hline $9 / 20$ & Mill & White Salmon & White Salmon & 12 & $\mathrm{Rb}$ & 153 & above horse ranch \\
\hline $9 / 20$ & Mill & White Salmon & White Salmon & 12 & $\mathrm{Rb}$ & 175 & above horse ranch \\
\hline $9 / 20$ & Mill & White Salmon & White Salmon & 12 & $\mathrm{Rb}$ & 152 & above horse ranch \\
\hline $9 / 20$ & Crofton & Morrison & White Salmon & 5 & & & above 73 trail, no fish \\
\hline $9 / 21$ & Unnamed \#3 & Cave & White Salmon & 8 & Bk & 62 & above Morris place, sds property \\
\hline $9 / 21$ & Unnamed \#3 & Cave & White Salmon & 8 & $\mathrm{Bk}$ & 72 & above Morris place, sds property \\
\hline $9 / 21$ & Unnamed \#3 & Cave & White Salmon & 8 & $\mathrm{Bk}$ & 68 & above Morris place, sds property \\
\hline $9 / 21$ & Unnamed \#3 & Cave & White Salmon & 8 & $\mathrm{Bk}$ & 63 & above Morris place, sds property \\
\hline $9 / 21$ & Unnamed \#3 & Cave & White Salmon & 8 & Bk & 66 & above Morris place, sds property \\
\hline $9 / 21$ & Unnamed \#3 & Cave & White Salmon & 8 & $\mathrm{Bk}$ & 56 & above Morris place, sds property \\
\hline $9 / 21$ & Unnamed \#3 & Cave & White Salmon & 8 & $\mathrm{Bk}$ & 46 & above Morris place, sds property \\
\hline $9 / 21$ & Unnamed \#3 & Cave & White Salmon & 8 & $\mathrm{Bk}$ & 60 & above Morris place, sds property \\
\hline $9 / 21$ & Unnamed \#3 & Cave & White Salmon & 8 & $\mathrm{Bk}$ & 56 & above Morris place, sds property \\
\hline $9 / 21$ & Unnamed \#3 & Cave & White Salmon & 8 & $\mathrm{Bk}$ & 68 & above Morris place, sds property \\
\hline $9 / 21$ & Unnamed \#3 & Cave & White Salmon & 8 & $\mathrm{Bk}$ & 60 & above Morris place, sds property \\
\hline $9 / 21$ & Unnamed \#3 & Cave & White Salmon & 8 & $\mathrm{Bk}$ & 75 & above Morris place, sds property \\
\hline $9 / 21$ & Unnamed \#3 & Cave & White Salmon & 8 & $\mathrm{Bk}$ & 61 & above Morris place, sds property \\
\hline $9 / 21$ & Unnamed \#3 & Cave & White Salmon & 8 & Bk & 60 & above Morris place, sds property \\
\hline $9 / 21$ & Unnamed \#3 & Cave & White Salmon & 8 & $\mathrm{Bk}$ & 41 & above Morris place, sds property \\
\hline $9 / 21$ & Unnamed \#3 & Cave & White Salmon & 8 & $\mathrm{Bk}$ & 54 & above Morris place, sds property \\
\hline $9 / 21$ & Unnamed \#3 & Cave & White Salmon & 8 & $\mathrm{Bk}$ & 167 & above Morris place, sds property \\
\hline $9 / 21$ & Unnamed \#3 & Cave & White Salmon & 8 & $\mathrm{Bk}$ & 169 & above Morris place, sds property \\
\hline $9 / 21$ & Unnamed \#3 & Cave & White Salmon & 8 & $\mathrm{Bk}$ & 167 & above Morris place, sds property \\
\hline $9 / 21$ & Unnamed \#3 & Cave & \begin{tabular}{|l|} 
White Salmon \\
\end{tabular} & 8 & $\mathrm{Bk}$ & 160 & above Morris place, sds property \\
\hline $9 / 21$ & Unnamed \#3 & Cave & White Salmon & 8 & $\mathrm{Bk}$ & 178 & above Morris place, sds property \\
\hline & & & & & & & \\
\hline
\end{tabular}


Appendix C. Electroshock data from streams in the Klickitat and White Salmon river basins, 2001.

\begin{tabular}{|c|c|c|c|c|c|c|c|}
\hline $7 / 30$ & Little Muddy & W. Fork Klickitat & Klickitat & 8.5 & $\mathrm{Bu}$ & 172 & \\
\hline $8 / 1$ & Elkhorn & Klickitat & Klickitat & 11.2 & & & above road, 13 rb's $<150,1$ rb $>150,1$ bk $>150,1$ unid'd fry \\
\hline $8 / 21$ & Unnamed \# 4 & Klickitat & Klickitat & 8.3 & $\mathrm{Rb}$ & 122 & north side of upper Klickitat \\
\hline $8 / 21$ & Unnamed \# 4 & Klickitat & Klickitat & 8.3 & $\mathrm{Rb}$ & 82 & north side of upper Klickitat \\
\hline $8 / 21$ & Unnamed \# 4 & Klickitat & Klickitat & 8.3 & $\mathrm{Rb}$ & 54 & north side of upper Klickitat \\
\hline $8 / 21$ & Unnamed \# 4 & Klickitat & Klickitat & 8.3 & $\mathrm{Rb}$ & 88 & north side of upper Klickitat \\
\hline $8 / 21$ & Unnamed \# 4 & Klickitat & Klickitat & 8.3 & $\mathrm{Rb}$ & 125 & north side of upper Klickitat \\
\hline $8 / 21$ & Unnamed \# 4 & Klickitat & Klickitat & 8.3 & $\mathrm{Rb}$ & 107 & north side of upper Klickitat \\
\hline $8 / 21$ & Unnamed \# 4 & Klickitat & Klickitat & 8.3 & $\mathrm{Rb}$ & 128 & north side of upper Klickitat \\
\hline $8 / 21$ & Unnamed \# 4 & Klickitat & Klickitat & 8.3 & $\mathrm{Rb}$ & 54 & north side of upper Klickitat \\
\hline $8 / 21$ & Unnamed \# 4 & Klickitat & Klickitat & 8.3 & $\mathrm{Rb}$ & 55 & north side of upper Klickitat \\
\hline $8 / 21$ & Unnamed \# 4 & Klickitat & Klickitat & 8.3 & $\mathrm{Rb}$ & 112 & north side of upper Klickitat \\
\hline $8 / 21$ & Unnamed \# 4 & Klickitat & Klickitat & 8.3 & $\mathrm{Rb}$ & 123 & north side of upper Klickitat \\
\hline $8 / 21$ & Klickitat & Columbia & Klickitat & 9.5 & $\mathrm{Rb}$ & 147 & below log barrier \\
\hline $8 / 21$ & Klickitat & Columbia & Klickitat & 9.5 & $\mathrm{Rb}$ & 124 & below log barrier \\
\hline $8 / 21$ & Klickitat & Columbia & Klickitat & 9.5 & $\mathrm{Rb}$ & 115 & below log barrier \\
\hline $8 / 21$ & Klickitat & Columbia & Klickitat & 9.5 & $\mathrm{Rb}$ & 148 & below log barrier \\
\hline $8 / 21$ & Klickitat & Columbia & Klickitat & 9.5 & $\mathrm{Rb}$ & 112 & below log barrier \\
\hline $8 / 21$ & Klickitat & Columbia & Klickitat & 9.5 & $\mathrm{Rb}$ & 162 & below log barrier \\
\hline $8 / 21$ & Klickitat & Columbia & Klickitat & 9.5 & $\mathrm{Rb}$ & 178 & below log barrier \\
\hline $8 / 21$ & Klickitat & Columbia & Klickitat & 9.5 & $\mathrm{Rb}$ & 158 & below log barrier \\
\hline $8 / 21$ & Klickitat & Columbia & Klickitat & 9.5 & $\mathrm{Rb}$ & 177 & above log barrier \\
\hline $8 / 21$ & Klickitat & Columbia & Klickitat & 9.5 & $\mathrm{Rb}$ & 220 & above log barrier \\
\hline $8 / 28$ & Pearl & Klickitat & Klickitat & 9.5 & & & none/upstream of upper road \\
\hline $9 / 10$ & Unnamed \# 1 & Diamond Fork & Klickitat & 8.5 & $\mathrm{Rb}$ & 52 & trib \# 4, east side \\
\hline $9 / 10$ & Unnamed \# 1 & Diamond Fork & Klickitat & 8.5 & $\mathrm{Rb}$ & 125 & trib \# 4, east side \\
\hline $9 / 10$ & Unnamed \# 1 & Diamond Fork & Klickitat & 8.5 & $\mathrm{Rb}$ & 133 & trib \# 4, east side \\
\hline $9 / 10$ & Unnamed \# 1 & Diamond Fork & Klickitat & 8.5 & $\mathrm{Rb}$ & 108 & trib \# 4, east side \\
\hline $9 / 10$ & Unnamed \# 1 & Diamond Fork & Klickitat & 8.5 & $\mathrm{Rb}$ & 115 & trib \# 4, east side \\
\hline $9 / 10$ & Unnamed \# 1 & Diamond Fork & Klickitat & 8.5 & $\mathrm{Rb}$ & 113 & trib \# 4, east side \\
\hline $9 / 10$ & Unnamed \# 1 & Diamond Fork & Klickitat & 8.5 & $\mathrm{Rb}$ & 128 & trib \# 4, east side \\
\hline $9 / 10$ & Unnamed \# 1 & Diamond Fork & Klickitat & 8.5 & $\mathrm{Rb}$ & 92 & trib \# 4, east side \\
\hline $9 / 10$ & Unnamed \# 1 & Diamond Fork & Klickitat & 8.5 & $\mathrm{Rb}$ & 146 & trib \# 4, east side \\
\hline $9 / 10$ & Unnamed \# 1 & Diamond Fork & Klickitat & 8.5 & $\mathrm{Rb}$ & 117 & trib \# 4, east side \\
\hline $9 / 10$ & Unnamed \# 1 & Diamond Fork & Klickitat & 8.5 & $\mathrm{Rb}$ & 131 & trib \# 4, east side \\
\hline $9 / 10$ & Unnamed \# 1 & Diamond Fork & Klickitat & 8.5 & $\mathrm{Rb}$ & 123 & trib \# 4, east side \\
\hline $9 / 10$ & Unnamed \# 1 & Diamond Fork & Klickitat & 8.5 & $\mathrm{Rb}$ & 146 & trib \# 4, east side \\
\hline $9 / 10$ & Unnamed \# 1 & Diamond Fork & Klickitat & 8.5 & $\mathrm{Rb}$ & 109 & trib \# 4, east side \\
\hline $9 / 10$ & Unnamed \# 1 & Diamond Fork & Klickitat & 8.5 & $\mathrm{Rb}$ & 71 & trib \# 4, east side \\
\hline $9 / 10$ & Unnamed \# 1 & Diamond Fork & Klickitat & 8.5 & $\mathrm{Rb}$ & 117 & trib \# 4, east side \\
\hline $9 / 10$ & Unnamed \# 1 & Diamond Fork & Klickitat & 8.5 & $\mathrm{Rb}$ & 97 & trib \# 4, east side \\
\hline $9 / 10$ & Unnamed \# 1 & Diamond Fork & Klickitat & 8.5 & $\mathrm{Rb}$ & 121 & trib \# 4, east side \\
\hline $9 / 10$ & Unnamed \# 1 & Diamond Fork & Klickitat & 8.5 & $\mathrm{Rb}$ & 115 & trib \# 4, east side \\
\hline $9 / 10$ & Unnamed \# 1 & Diamond Fork & Klickitat & 8.5 & $\mathrm{Rb}$ & 100 & trib \# 4, east side \\
\hline $9 / 10$ & Unnamed \# 1 & Diamond Fork & Klickitat & 8.5 & $\mathrm{Rb}$ & 126 & trib \# 4, east side \\
\hline $9 / 10$ & Unnamed \# 1 & Diamond Fork & Klickitat & 8.5 & $\mathrm{Rb}$ & 99 & trib \# 4, east side \\
\hline $9 / 10$ & Unnamed \# 1 & Diamond Fork & Klickitat & 8.5 & $\mathrm{Rb}$ & 114 & trib \# 4, east side \\
\hline $9 / 10$ & Unnamed \# 1 & Diamond Fork & Klickitat & 8.5 & $\mathrm{Rb}$ & 154 & trib \# 4, east side \\
\hline $9 / 10$ & Unnamed \# 1 & Diamond Fork & \begin{tabular}{|l|} 
Klickitat \\
\end{tabular} & 8.5 & $\mathrm{Rb}$ & 165 & trib \# 4, east side \\
\hline $9 / 10$ & Unnamed \# 2 & Diamond Fork & Klickitat & 10.5 & $\mathrm{Rb}$ & 109 & trib \# 3, east side \\
\hline $9 / 10$ & Unnamed \# 2 & Diamond Fork & Klickitat & 10.5 & $\mathrm{Rb}$ & 106 & trib \# 3, east side \\
\hline $9 / 10$ & Unnamed \# 2 & Diamond Fork & Klickitat & 10.5 & $\mathrm{Rb}$ & 74 & trib \# 3, east side \\
\hline $9 / 10$ & Unnamed \# 2 & Diamond Fork & Klickitat & 10.5 & $\mathrm{Rb}$ & 122 & trib \# 3, east side \\
\hline $9 / 10$ & Unnamed \# 2 & Diamond Fork & Klickitat & 10.5 & $\mathrm{Rb}$ & 78 & trib \# 3, east side \\
\hline $9 / 10$ & Unnamed \# 2 & Diamond Fork & Klickitat & 10.5 & $\mathrm{Rb}$ & 72 & trib \# 3, east side \\
\hline $9 / 10$ & Unnamed \# 2 & Diamond Fork & Klickitat & 10.5 & $\mathrm{Rb}$ & 99 & trib \# 3, east side \\
\hline $9 / 10$ & Unnamed \# 2 & Diamond Fork & Klickitat & 10.5 & $\mathrm{Rb}$ & 73 & trib \# 3, east side \\
\hline $9 / 10$ & Unnamed \# 2 & Diamond Fork & Klickitat & 10.5 & $\mathrm{Rb}$ & 75 & trib \# 3, east side \\
\hline $9 / 10$ & Unnamed \# 2 & Diamond Fork & Klickitat & 10.5 & $\mathrm{Rb}$ & 77 & trib \# 3, east side \\
\hline $9 / 10$ & Unnamed \# 2 & Diamond Fork & \begin{tabular}{|l|} 
Klickitat \\
\end{tabular} & 10.5 & $\mathrm{Rb}$ & 36 & trib \# 3, east side \\
\hline $9 / 10$ & Unnamed \# 2 & Diamond Fork & Klickitat & 10.5 & $\mathrm{Rb}$ & 107 & trib \# 3, east side \\
\hline $9 / 10$ & Unnamed \# 2 & Diamond Fork & Klickitat & 10.5 & $\mathrm{Rb}$ & 147 & trib \# 3, east side \\
\hline $9 / 10$ & Unnamed \# 2 & Diamond Fork & Klickitat & 10.5 & $\mathrm{Rb}$ & 100 & trib \# 3, east side \\
\hline $9 / 10$ & Unnamed \# 2 & Diamond Fork & Klickitat & 10.5 & $\mathrm{Rb}$ & 71 & trib \# 3, east side \\
\hline $9 / 10$ & Unnamed \# 2 & Diamond Fork & Klickitat & 10.5 & $\mathrm{Rb}$ & 91 & trib \# 3, east side \\
\hline $9 / 10$ & Unnamed \# 2 & Diamond Fork & Klickitat & 10.5 & $\mathrm{Rb}$ & 127 & trib \# 3, east side \\
\hline $9 / 10$ & Unnamed \# 2 & \begin{tabular}{|l} 
Diamond Fork \\
\end{tabular} & Klickitat & 10.5 & $\mathrm{Rb}$ & 71 & trib \# 3, east side \\
\hline $9 / 10$ & Unnamed \# 2 & Diamond Fork & Klickitat & 10.5 & $\mathrm{Rb}$ & 81 & trib \# 3, east side \\
\hline $9 / 10$ & Unnamed \# 2 & Diamond Fork & Klickitat & 10.5 & $\mathrm{Rb}$ & 104 & trib \# 3, east side \\
\hline
\end{tabular}


Appendix C. Electroshock data from streams in the Klickitat and White Salmon river basins, 2001.

\begin{tabular}{|c|c|c|c|c|c|c|c|}
\hline $9 / 10$ & Unnamed \# 2 & Diamond Fork & Klickitat & 10.5 & $\mathrm{Rb}$ & 116 & trib \# 3, east side \\
\hline $9 / 10$ & Unnamed \# 2 & Diamond Fork & Klickitat & 10.5 & $\mathrm{Rb}$ & 72 & trib \# 3, east side \\
\hline $9 / 10$ & Unnamed \# 2 & Diamond Fork & Klickitat & 10.5 & $\mathrm{Rb}$ & 76 & trib \# 3, east side \\
\hline $9 / 10$ & Unnamed \# 2 & Diamond Fork & Klickitat & 10.5 & $\mathrm{Rb}$ & 113 & trib \# 3, east side \\
\hline $9 / 10$ & Unnamed \# 2 & Diamond Fork & Klickitat & 10.5 & $\mathrm{Rb}$ & 117 & trib \# 3, east side \\
\hline $9 / 10$ & Unnamed \# 2 & Diamond Fork & Klickitat & 10.5 & $\mathrm{Rb}$ & 87 & trib \# 3, east side \\
\hline $9 / 10$ & Unnamed \# 2 & Diamond Fork & Klickitat & 10.5 & $\mathrm{Rb}$ & 79 & trib \# 3, east side \\
\hline $9 / 10$ & Unnamed \# 2 & Diamond Fork & Klickitat & 10.5 & $\mathrm{Rb}$ & 133 & trib \# 3, east side \\
\hline $9 / 10$ & Unnamed \# 2 & Diamond Fork & Klickitat & 10.5 & $\mathrm{Rb}$ & 70 & trib \# 3, east side \\
\hline $9 / 10$ & Unnamed \# 2 & Diamond Fork & Klickitat & 10.5 & $\mathrm{Rb}$ & 107 & trib \# 3, east side \\
\hline $9 / 10$ & Unnamed \# 2 & Diamond Fork & Klickitat & 10.5 & $\mathrm{Rb}$ & 92 & trib \# 3, east side \\
\hline $9 / 10$ & Unnamed \# 2 & Diamond Fork & Klickitat & 10.5 & $\mathrm{Rb}$ & 78 & trib \# 3, east side \\
\hline $9 / 10$ & Unnamed \# 2 & Diamond Fork & Klickitat & 10.5 & $\mathrm{Rb}$ & 65 & trib \# 3, east side \\
\hline $9 / 10$ & Unnamed \# 2 & Diamond Fork & Klickitat & 10.5 & $\mathrm{Rb}$ & 85 & trib \# 3, east side \\
\hline $9 / 10$ & Unnamed \# 2 & Diamond Fork & Klickitat & 10.5 & $\mathrm{Rb}$ & 74 & trib \# 3, east side \\
\hline $9 / 10$ & Unnamed \# 2 & Diamond Fork & Klickitat & 10.5 & $\mathrm{Rb}$ & 108 & trib \# 3, east side \\
\hline $9 / 10$ & Unnamed \# 2 & Diamond Fork & Klickitat & 10.5 & $\mathrm{Rb}$ & 110 & trib \# 3, east side \\
\hline $9 / 10$ & Unnamed \# 2 & Diamond Fork & Klickitat & 10.5 & $\mathrm{Rb}$ & 104 & trib \# 3, east side \\
\hline $9 / 10$ & Unnamed \# 2 & Diamond Fork & Klickitat & 10.5 & $\mathrm{Rb}$ & 118 & trib \# 3, east side \\
\hline $9 / 10$ & Unnamed \# 2 & Diamond Fork & Klickitat & 10.5 & $\mathrm{Rb}$ & 125 & trib \# 3, east side \\
\hline $9 / 10$ & Unnamed \# 2 & Diamond Fork & Klickitat & 10.5 & $\mathrm{Rb}$ & 113 & trib \# 3, east side \\
\hline $9 / 10$ & Unnamed \# 2 & Diamond Fork & Klickitat & 10.5 & $\mathrm{Rb}$ & 94 & trib \# 3, east side \\
\hline $9 / 10$ & Unnamed \# 2 & Diamond Fork & Klickitat & 10.5 & $\mathrm{Rb}$ & 108 & trib \# 3, east side \\
\hline $9 / 10$ & Unnamed \# 2 & Diamond Fork & Klickitat & 10.5 & $\mathrm{Rb}$ & 64 & trib \# 3, east side \\
\hline $9 / 10$ & Unnamed \# 2 & Diamond Fork & Klickitat & 10.5 & $\mathrm{Rb}$ & 59 & trib \# 3, east side \\
\hline $9 / 10$ & Unnamed \# 2 & Diamond Fork & Klickitat & 10.5 & $\mathrm{Rb}$ & 72 & trib \# 3, east side \\
\hline $9 / 10$ & Unnamed \# 2 & Diamond Fork & Klickitat & 10.5 & $\mathrm{Rb}$ & 75 & trib \# 3, east side \\
\hline $9 / 10$ & Unnamed \# 2 & Diamond Fork & Klickitat & 10.5 & $\mathrm{Rb}$ & 67 & trib \# 3, east side \\
\hline $9 / 10$ & Unnamed \# 2 & Diamond Fork & Klickitat & 10.5 & $\mathrm{Rb}$ & 62 & trib \# 3, east side \\
\hline $9 / 10$ & Unnamed \# 2 & Diamond Fork & Klickitat & 10.5 & $\mathrm{Rb}$ & 70 & trib \# 3, east side \\
\hline $9 / 10$ & Unnamed \# 2 & Diamond Fork & Klickitat & 10.5 & $\mathrm{Rb}$ & 115 & trib \# 3, east side \\
\hline $9 / 10$ & Unnamed \# 2 & Diamond Fork & Klickitat & 10.5 & $\mathrm{Rb}$ & 117 & trib \# 3, east side \\
\hline $9 / 10$ & Unnamed \# 2 & Diamond Fork & Klickitat & 10.5 & $\mathrm{Rb}$ & 158 & trib \# 3, east side \\
\hline $9 / 10$ & Unnamed \# 2 & Diamond Fork & Klickitat & 10.5 & $\mathrm{Rb}$ & 156 & trib \# 3, east side \\
\hline $9 / 10$ & Unnamed \# 2 & Diamond Fork & Klickitat & 10.5 & $\mathrm{Rb}$ & 181 & trib \# 3, east side \\
\hline $9 / 10$ & Unnamed \# 2 & Diamond Fork & Klickitat & 10.5 & $\mathrm{Rb}$ & 158 & trib \# 3, east side \\
\hline $9 / 11$ & Unnamed \#3 & Diamond Fork & Klickitat & 10 & $\mathrm{Rb}$ & 66 & trib \# 2, east side \\
\hline $9 / 11$ & Unnamed \#3 & Diamond Fork & Klickitat & 10 & $\mathrm{Rb}$ & 66 & trib \# 2, east side \\
\hline $9 / 11$ & Unnamed \#3 & Diamond Fork & Klickitat & 10 & $\mathrm{Rb}$ & 62 & trib \# 2, east side \\
\hline $9 / 11$ & Unnamed \#3 & Diamond Fork & Klickitat & 10 & $\mathrm{Rb}$ & 145 & trib \# 2, east side \\
\hline $9 / 11$ & Unnamed \#3 & Diamond Fork & Klickitat & 10 & $\mathrm{Rb}$ & 71 & trib \# 2, east side \\
\hline $9 / 11$ & Unnamed \#3 & Diamond Fork & Klickitat & 10 & $\mathrm{Rb}$ & 65 & trib \# 2, east side \\
\hline $9 / 11$ & Unnamed \#3 & Diamond Fork & Klickitat & 10 & $\mathrm{Rb}$ & 60 & trib \# 2, east side \\
\hline $9 / 11$ & Unnamed \#3 & Diamond Fork & Klickitat & 10 & $\mathrm{Rb}$ & 120 & trib \# 2, east side \\
\hline $9 / 11$ & Unnamed \#3 & Diamond Fork & Klickitat & 10 & $\mathrm{Rb}$ & 106 & trib \# 2, east side \\
\hline $9 / 11$ & Unnamed \#3 & Diamond Fork & Klickitat & 10 & $\mathrm{Rb}$ & 58 & trib \# 2, east side \\
\hline $9 / 11$ & Unnamed \#3 & Diamond Fork & Klickitat & 10 & $\mathrm{Rb}$ & 91 & trib \# 2, east side \\
\hline $9 / 11$ & Unnamed \#3 & Diamond Fork & Klickitat & 10 & $\mathrm{Rb}$ & 90 & trib \# 2, east side \\
\hline $9 / 11$ & Unnamed \#3 & Diamond Fork & Klickitat & 10 & $\mathrm{Rb}$ & 28 & trib \# 2, east side \\
\hline $9 / 11$ & Unnamed \#3 & Diamond Fork & Klickitat & 10 & $\mathrm{Rb}$ & 82 & trib \# 2, east side \\
\hline $9 / 11$ & Unnamed \#3 & Diamond Fork & Klickitat & 10 & $\mathrm{Rb}$ & 75 & trib \# 2, east side \\
\hline $9 / 11$ & Unnamed \#3 & Diamond Fork & Klickitat & 10 & $\mathrm{Rb}$ & 68 & trib \# 2, east side \\
\hline $9 / 11$ & Unnamed \#3 & Diamond Fork & Klickitat & 10 & $\mathrm{Rb}$ & 112 & trib \# 2, east side \\
\hline $9 / 11$ & Unnamed \#3 & Diamond Fork & Klickitat & 10 & $\mathrm{Rb}$ & 99 & trib \# 2, east side \\
\hline $9 / 11$ & Unnamed \#3 & Diamond Fork & Klickitat & 10 & $\mathrm{Rb}$ & 65 & trib \# 2, east side \\
\hline $9 / 11$ & Unnamed \#3 & Diamond Fork & Klickitat & 10 & $\mathrm{Rb}$ & 105 & trib \# 2, east side \\
\hline $9 / 11$ & Unnamed \#3 & Diamond Fork & Klickitat & 10 & $\mathrm{Rb}$ & 107 & trib \# 2, east side \\
\hline $9 / 11$ & Unnamed \#3 & Diamond Fork & Klickitat & 10 & $\mathrm{Rb}$ & 67 & trib \# 2, east side \\
\hline $9 / 11$ & Unnamed \#3 & Diamond Fork & Klickitat & 10 & $\mathrm{Rb}$ & 65 & trib \# 2, east side \\
\hline $9 / 11$ & Unnamed \#3 & Diamond Fork & Klickitat & 10 & $\mathrm{Rb}$ & 98 & trib \# 2, east side \\
\hline $9 / 11$ & Unnamed \#3 & Diamond Fork & Klickitat & 10 & $\mathrm{Rb}$ & 65 & trib \# 2, east side \\
\hline $9 / 11$ & Unnamed \#3 & Diamond Fork & Klickitat & 10 & $\mathrm{Rb}$ & 214 & trib \# 2, east side \\
\hline $9 / 11$ & Unnamed \#3 & Diamond Fork & Klickitat & 10 & $\mathrm{Rb}$ & 150 & trib \# 2, east side \\
\hline $9 / 11$ & Unnamed \#3 & Diamond Fork & Klickitat & 10 & $\mathrm{Rb}$ & 160 & trib \# 2, east side \\
\hline $9 / 12$ & Unnamed \#4 & Diamond Fork & Klickitat & 9.5 & & & none; trib \#2 west side \\
\hline $9 / 12$ & Unnamed \#5 & Diamond Fork & Klickitat & 9 & & & none; trib \#3 west side \\
\hline $9 / 18$ & Unnamed \#6 & Diamond Fork & Klickitat & 6.8 & & & none; trib \#1 east side \\
\hline $9 / 18$ & Unnamed \#7 & Diamond Fork & Klickitat & 5.2 & $\mathrm{Rb}$ & 85 & trib \#5 east side \\
\hline $9 / 18$ & Unnamed \#7 & Diamond Fork & Klickitat & 5.2 & Bk & 109 & trib \#5 east side \\
\hline
\end{tabular}


Appendix C. Electroshock data from streams in the Klickitat and White Salmon river basins, 2001.

\begin{tabular}{|c|c|c|c|c|c|c|c|}
\hline $9 / 18$ & Unnamed \#8 & Diamond Fork & Klickitat & 6.4 & & & none; trib \#6 east side \\
\hline $9 / 18$ & Unnamed \#9 & Diamond Fork & Klickitat & 6.7 & & & none; trib A west side \\
\hline $9 / 18$ & Unnamed \#10 & Diamond Fork & Klickitat & 7.2 & $\mathrm{Rb}$ & 148 & trib. B, below confluence of north and south fork \\
\hline $9 / 18$ & Unnamed \#10 & Diamond Fork & Klickitat & 7.2 & $\mathrm{Rb}$ & 177 & trib. B, below confluence of north and south fork \\
\hline $9 / 18$ & Unnamed \#10 & Diamond Fork & Klickitat & 7.2 & $\mathrm{Rb}$ & 166 & trib. B, below confluence of north and south fork \\
\hline $9 / 18$ & Unnamed \#10 & Diamond Fork & Klickitat & 7.2 & $\mathrm{Rb}$ & 137 & trib. B, below confluence of north and south fork \\
\hline $9 / 18$ & Unnamed \#10 & Diamond Fork & Klickitat & 7.2 & $\mathrm{Rb}$ & 143 & trib. B, below confluence of north and south fork \\
\hline $9 / 18$ & Unnamed \#10 & Diamond Fork & Klickitat & 7.2 & Bk & 190 & trib. B, below confluence of north and south fork \\
\hline $9 / 18$ & Unnamed \#10 & Diamond Fork & Klickitat & 7.2 & $\mathrm{Bk}$ & 170 & trib. B, below confluence of north and south fork \\
\hline $9 / 18$ & Unnamed \#10 & Diamond Fork & Klickitat & 7.2 & $\mathrm{Bk}$ & 90 & trib. B, below confluence of north and south fork \\
\hline $9 / 18$ & Unnamed \#10 & Diamond Fork & Klickitat & 7.2 & $\mathrm{Bk}$ & 104 & trib. B, below confluence of north and south fork \\
\hline $9 / 18$ & Unnamed \#10 & Diamond Fork & Klickitat & 7.2 & $\mathrm{Bk}$ & 84 & trib. B, below confluence of north and south fork \\
\hline $9 / 18$ & Unnamed \#10 & Diamond Fork & Klickitat & 7.2 & $\mathrm{Bk}$ & 49 & trib. B, below confluence of north and south fork \\
\hline $9 / 18$ & Unnamed \#10 & Diamond Fork & Klickitat & 7.2 & $\mathrm{Bk}$ & 95 & trib. B, below confluence of north and south fork \\
\hline $9 / 18$ & Unnamed \#10 & Diamond Fork & Klickitat & 7.2 & $\mathrm{Bk}$ & 51 & trib. B, below confluence of north and south fork \\
\hline $9 / 18$ & Unnamed \#10 & Diamond Fork & Klickitat & 7.2 & $\mathrm{Bk}$ & 54 & trib. B, below confluence of north and south fork \\
\hline $9 / 18$ & Unnamed \#10 & Diamond Fork & Klickitat & 7.2 & Bk & 30 & trib. B, below confluence of north and south fork \\
\hline $9 / 18$ & Unnamed \#10 & Diamond Fork & Klickitat & 7.2 & $\mathrm{Bk}$ & 49 & trib. B, below confluence of north and south fork \\
\hline $9 / 18$ & Unnamed \#10 & Diamond Fork & Klickitat & 7.2 & $\mathrm{Bk}$ & 93 & trib. B, below confluence of north and south fork \\
\hline $9 / 18$ & Unnamed \#10 & Diamond Fork & Klickitat & 7.2 & $\mathrm{Bk}$ & 48 & trib. B, below confluence of north and south fork \\
\hline $9 / 18$ & Unnamed \#10 & Diamond Fork & Klickitat & 7.2 & $\mathrm{Bk}$ & 54 & trib. B, below confluence of north and south fork \\
\hline $9 / 18$ & Unnamed \#10 & Diamond Fork & Klickitat & 7.2 & $\mathrm{Bk}$ & 40 & trib. B, below confluence of north and south fork \\
\hline $9 / 18$ & Unnamed \#10 & Diamond Fork & Klickitat & 7.2 & $\mathrm{Bk}$ & 46 & trib. B, below confluence of north and south fork \\
\hline $9 / 18$ & Unnamed \#10 & Diamond Fork & Klickitat & 7.2 & $\mathrm{Bk}$ & 42 & trib. B, below confluence of north and south fork \\
\hline $9 / 18$ & Unnamed \#10 & Diamond Fork & Klickitat & 7.2 & $\mathrm{Bk}$ & 32 & trib. B, below confluence of north and south fork \\
\hline $9 / 18$ & Unnamed \#10 & Diamond Fork & Klickitat & 7.2 & $\mathrm{Bk}$ & 108 & trib. B, below confluence of north and south fork \\
\hline $9 / 18$ & Unnamed \#10 & Diamond Fork & Klickitat & 7.2 & $\mathrm{Bk}$ & 87 & trib. B, below confluence of north and south fork \\
\hline $9 / 18$ & Unnamed \#10 & Diamond Fork & Klickitat & 7.2 & $\mathrm{Bk}$ & 36 & trib. B, below confluence of north and south fork \\
\hline $9 / 18$ & Unnamed \#10 & Diamond Fork & Klickitat & 7.2 & $\mathrm{Bk}$ & 37 & trib. B, below confluence of north and south fork \\
\hline $9 / 18$ & Unnamed \#10 & Diamond Fork & Klickitat & 7.2 & $\mathrm{Bk}$ & 150 & trib. B, below confluence of north and south fork \\
\hline $9 / 18$ & Unnamed \#10 & Diamond Fork & Klickitat & 7.2 & $\mathrm{Bk}$ & 47 & trib. B, below confluence of north and south fork \\
\hline $9 / 18$ & Unnamed \#10 & Diamond Fork & Klickitat & 7.2 & $\mathrm{Bk}$ & 53 & trib. B, below confluence of north and south fork \\
\hline $9 / 18$ & Unnamed \#10 & Diamond Fork & Klickitat & 7.2 & $\mathrm{Bk}$ & 45 & trib. B, below confluence of north and south fork \\
\hline $9 / 18$ & Unnamed \#10 & Diamond Fork & Klickitat & 7.2 & $\mathrm{Bk}$ & 48 & trib. B, below confluence of north and south fork \\
\hline $9 / 18$ & Unnamed \#10 & Diamond Fork & Klickitat & 7.2 & Bk & 51 & trib. B, below confluence of north and south fork \\
\hline $9 / 18$ & Unnamed \#10 & Diamond Fork & Klickitat & 7.2 & $\mathrm{Bk}$ & 28 & trib. B, below confluence of north and south fork \\
\hline $9 / 18$ & Unnamed \#10 & Diamond Fork & Klickitat & 7.2 & $\mathrm{Bk}$ & 45 & trib. B, below confluence of north and south fork \\
\hline $9 / 18$ & Unnamed \#10 & Diamond Fork & Klickitat & 7.2 & $\mathrm{Bk}$ & 44 & trib. B, below confluence of north and south fork \\
\hline $9 / 18$ & Unnamed \#11 & Diamond Fork & Klickitat & 6.5 & $\mathrm{Bk}$ & 49 & lower site, south fork of trib. B \\
\hline $9 / 18$ & Unnamed \#11 & Diamond Fork & Klickitat & 6.5 & $\mathrm{Bk}$ & 51 & lower site, south fork of trib. B \\
\hline $9 / 18$ & Unnamed \#11 & Diamond Fork & Klickitat & 6.5 & Bk & 47 & lower site, south fork of trib. B \\
\hline $9 / 18$ & Unnamed \#11 & Diamond Fork & Klickitat & 6.5 & $\mathrm{Bk}$ & 50 & lower site, south fork of trib. B \\
\hline $9 / 18$ & Unnamed \#11 & Diamond Fork & Klickitat & 6.5 & $\mathrm{Bk}$ & 111 & lower site, south fork of trib. B \\
\hline $9 / 18$ & Unnamed \#11 & Diamond Fork & Klickitat & 6.5 & $\mathrm{Bk}$ & 45 & lower site, south fork of trib. B \\
\hline $9 / 18$ & Unnamed \#11 & Diamond Fork & Klickitat & 6.5 & $\mathrm{Bk}$ & 41 & lower site, south fork of trib. B \\
\hline $9 / 18$ & Unnamed \#11 & Diamond Fork & Klickitat & 6.5 & $\mathrm{Bk}$ & 44 & lower site, south fork of trib. B \\
\hline $9 / 18$ & Unnamed \#11 & Diamond Fork & Klickitat & 6.5 & $\mathrm{Bk}$ & 54 & lower site, south fork of trib. B \\
\hline $9 / 18$ & Unnamed \#11 & Diamond Fork & Klickitat & 6.5 & $\mathrm{Bk}$ & 47 & lower site, south fork of trib. B \\
\hline $9 / 18$ & Unnamed \#11 & Diamond Fork & Klickitat & 6.5 & $\mathrm{Bk}$ & 175 & lower site, south fork of trib. B \\
\hline $9 / 18$ & Unnamed \#11 & Diamond Fork & Klickitat & 6.5 & $\mathrm{Bk}$ & 51 & lower site, south fork of trib. B \\
\hline $9 / 18$ & Unnamed \#11 & Diamond Fork & Klickitat & 6.5 & $\mathrm{Bk}$ & 54 & lower site, south fork of trib. B \\
\hline $9 / 18$ & Unnamed \#11 & Diamond Fork & Klickitat & 6.5 & $\mathrm{Bk}$ & 35 & lower site, south fork of trib. B \\
\hline $9 / 18$ & Unnamed \#11 & Diamond Fork & Klickitat & 6.5 & $\mathrm{Bk}$ & 52 & lower site, south fork of trib. B \\
\hline $9 / 18$ & Unnamed \#11 & Diamond Fork & Klickitat & 6.5 & $\mathrm{Bk}$ & 42 & lower site, south fork of trib. B \\
\hline $9 / 18$ & Unnamed \#11 & Diamond Fork & Klickitat & 6.5 & $\mathrm{Bk}$ & 32 & lower site, south fork of trib. B \\
\hline $9 / 18$ & Unnamed \#11 & Diamond Fork & Klickitat & 6.5 & $\mathrm{Bk}$ & 108 & lower site, south fork of trib. B \\
\hline $9 / 18$ & Unnamed \#11 & Diamond Fork & Klickitat & 6.5 & $\mathrm{Bk}$ & 87 & lower site, south fork of trib. B \\
\hline $9 / 18$ & Unnamed \#11 & Diamond Fork & Klickitat & 6.5 & $\mathrm{Bk}$ & 36 & lower site, south fork of trib. B \\
\hline $9 / 18$ & Unnamed \#11 & Diamond Fork & Klickitat & 6.5 & Bk & 37 & lower site, south fork of trib. B \\
\hline $9 / 18$ & Unnamed \#11 & Diamond Fork & Klickitat & 6.5 & $\mathrm{Bk}$ & 150 & lower site, south fork of trib. B \\
\hline $9 / 18$ & Unnamed \#11 & Diamond Fork & Klickitat & 6.5 & $\mathrm{Bk}$ & 47 & lower site, south fork of trib. B \\
\hline $9 / 18$ & Unnamed \#11 & Diamond Fork & Klickitat & 6.5 & $\mathrm{Bk}$ & 53 & lower site, south fork of trib. B \\
\hline $9 / 18$ & Unnamed \#11 & Diamond Fork & Klickitat & 6.5 & $\mathrm{Bk}$ & 45 & lower site, south fork of trib. B \\
\hline $9 / 18$ & Unnamed \#11 & Diamond Fork & Klickitat & 6.5 & $\mathrm{Bk}$ & 48 & lower site, south fork of trib. B \\
\hline $9 / 18$ & Unnamed \#11 & Diamond Fork & Klickitat & 6.5 & $\mathrm{Bk}$ & 45 & lower site, south fork of trib. B \\
\hline $9 / 18$ & Unnamed \#11 & Diamond Fork & Klickitat & 6.5 & $\mathrm{Bk}$ & 48 & lower site, south fork of trib. B \\
\hline $9 / 18$ & Unnamed \#11 & Diamond Fork & Klickitat & 6.5 & $\mathrm{Bk}$ & 51 & lower site, south fork of trib. B \\
\hline $9 / 18$ & Unnamed \#11 & Diamond Fork & Klickitat & 6.5 & $\mathrm{Bk}$ & 28 & lower site, south fork of trib. B \\
\hline $9 / 18$ & Unnamed \#11 & Diamond Fork & Klickitat & 6.5 & $\mathrm{Bk}$ & 45 & lower site, south fork of trib. B \\
\hline
\end{tabular}


Appendix C. Electroshock data from streams in the Klickitat and White Salmon river basins, 2001.

\begin{tabular}{|c|c|c|c|c|c|c|c|}
\hline $9 / 18$ & Unnamed \#11 & Diamond Fork & Klickitat & 6.5 & Bk & 44 & lower site, south fork of trib. B \\
\hline $9 / 19$ & Unnamed \#12 & Diamond Fork & \begin{tabular}{|l|} 
Klickitat \\
\end{tabular} & 5 & $\mathrm{Bk}$ & 38 & upper site, south fork of trib. B \\
\hline $9 / 19$ & Unnamed \#12 & Diamond Fork & Klickitat & 5 & Bk & 36 & upper site, south fork of trib. B \\
\hline $9 / 19$ & Unnamed \#12 & Diamond Fork & Klickitat & 5 & $\mathrm{Bk}$ & 128 & upper site, south fork of trib. B \\
\hline $9 / 19$ & Unnamed \#12 & Diamond Fork & Klickitat & 5 & $\mathrm{Bk}$ & 128 & upper site, south fork of trib. B \\
\hline $9 / 19$ & Unnamed \#12 & Diamond Fork & Klickitat & 5 & $\mathrm{Bk}$ & 111 & upper site, south fork of trib. B \\
\hline $9 / 19$ & Unnamed \#12 & Diamond Fork & Klickitat & 5 & $\mathrm{Bk}$ & 127 & upper site, south fork of trib. $B$ \\
\hline $9 / 19$ & Unnamed \#12 & Diamond Fork & Klickitat & 5 & Bk & 93 & upper site, south fork of trib. B \\
\hline $9 / 19$ & Unnamed \#12 & Diamond Fork & Klickitat & 5 & Bk & 74 & upper site, south fork of trib. B \\
\hline $9 / 19$ & Unnamed \#12 & Diamond Fork & Klickitat & 5 & Bk & 56 & upper site, south fork of trib. B \\
\hline $9 / 19$ & Unnamed \#13 & Diamond Fork & Klickitat & 6.8 & $\mathrm{Bk}$ & 100 & north fork of trib. B \\
\hline $9 / 19$ & Unnamed \#13 & Diamond Fork & Klickitat & 6.8 & Bk & 95 & north fork of trib. B \\
\hline $9 / 19$ & Unnamed \#13 & Diamond Fork & \begin{tabular}{|l|} 
Klickitat \\
\end{tabular} & 6.8 & $\mathrm{Bk}$ & 43 & north fork of trib. B \\
\hline $9 / 19$ & Unnamed \#13 & Diamond Fork & Klickitat & 6.8 & $\mathrm{Bk}$ & 46 & north fork of trib. B \\
\hline $9 / 19$ & Unnamed \#13 & Diamond Fork & Klickitat & 6.8 & Bk & 42 & north fork of trib. B \\
\hline $9 / 19$ & Unnamed \#13 & Diamond Fork & Klickitat & 6.8 & Bk & 98 & north fork of trib. B \\
\hline $9 / 19$ & Unnamed \#13 & Diamond Fork & Klickitat & 6.8 & $\mathrm{Bk}$ & 45 & north fork of trib. B \\
\hline $9 / 19$ & Unnamed \#13 & Diamond Fork & Klickitat & 6.8 & Bk & 46 & north fork of trib. B \\
\hline $9 / 19$ & Unnamed \#13 & \begin{tabular}{|l} 
Diamond Fork \\
\end{tabular} & Klickitat & 6.8 & $\mathrm{Bk}$ & 146 & north fork of trib. B \\
\hline $9 / 19$ & Unnamed \#13 & \begin{tabular}{|l|} 
Diamond Fork \\
\end{tabular} & Klickitat & 6.8 & $\mathrm{Bk}$ & 47 & north fork of trib. B \\
\hline $9 / 19$ & Unnamed \#13 & Diamond Fork & Klickitat & 6.8 & $\mathrm{Bk}$ & 42 & north fork of trib. B \\
\hline $9 / 19$ & Unnamed \#13 & Diamond Fork & Klickitat & 6.8 & $\mathrm{Bk}$ & 40 & north fork of trib. B \\
\hline $9 / 19$ & Unnamed \#13 & Diamond Fork & Klickitat & 6.8 & $\mathrm{Bk}$ & 118 & north fork of trib. B \\
\hline $9 / 19$ & Unnamed \#13 & Diamond Fork & Klickitat & 6.8 & $\mathrm{Bk}$ & 104 & north fork of trib. B \\
\hline $9 / 19$ & Unnamed \#13 & Diamond Fork & Klickitat & 6.8 & $\mathrm{Bk}$ & 76 & north fork of trib. B \\
\hline $9 / 19$ & Unnamed \#13 & Diamond Fork & Klickitat & 6.8 & $\mathrm{Bk}$ & 39 & north fork of trib. B \\
\hline $9 / 19$ & Unnamed \#13 & Diamond Fork & Klickitat & 6.8 & $\mathrm{Bk}$ & 42 & north fork of trib. B \\
\hline $9 / 19$ & Unnamed \#13 & Diamond Fork & Klickitat & 6.8 & $\mathrm{Bk}$ & 40 & north fork of trib. B \\
\hline $9 / 19$ & Unnamed \#13 & Diamond Fork & Klickitat & 6.8 & $\mathrm{Bk}$ & 38 & north fork of trib. B \\
\hline $9 / 19$ & Unnamed \#13 & Diamond Fork & Klickitat & 6.8 & $\mathrm{Bk}$ & 46 & north fork of trib. B \\
\hline $9 / 19$ & Unnamed \#13 & Diamond Fork & Klickitat & 6.8 & $\mathrm{Bk}$ & 41 & north fork of trib. B \\
\hline $9 / 19$ & Unnamed \#13 & Diamond Fork & Klickitat & 6.8 & $\mathrm{Bk}$ & 123 & north fork of trib. B \\
\hline $9 / 19$ & Unnamed \#13 & Diamond Fork & Klickitat & 6.8 & $\mathrm{Bk}$ & 84 & north fork of trib. B \\
\hline $9 / 19$ & Unnamed \#13 & Diamond Fork & Klickitat & 6.8 & $\mathrm{Bk}$ & 78 & north fork of trib. B \\
\hline $9 / 19$ & Unnamed \#13 & Diamond Fork & Klickitat & 6.8 & $\mathrm{Bk}$ & 130 & north fork of trib. B \\
\hline $9 / 19$ & Unnamed \#13 & Diamond Fork & Klickitat & 6.8 & $\mathrm{Bk}$ & 78 & north fork of trib. B \\
\hline $9 / 19$ & Unnamed \#13 & Diamond Fork & Klickitat & 6.8 & $\mathrm{Bk}$ & 45 & north fork of trib. B \\
\hline $9 / 19$ & Unnamed \#13 & Diamond Fork & Klickitat & 6.8 & $\mathrm{Bk}$ & 45 & north fork of trib. B \\
\hline $9 / 19$ & Unnamed \#13 & Diamond Fork & Klickitat & 6.8 & $\mathrm{Bk}$ & 35 & north fork of trib. B \\
\hline $9 / 19$ & Unnamed \#13 & Diamond Fork & Klickitat & 6.8 & $\mathrm{Bk}$ & 47 & north fork of trib. B \\
\hline $9 / 19$ & Unnamed \#13 & Diamond Fork & Klickitat & 6.8 & $\mathrm{Bk}$ & 44 & north fork of trib. B \\
\hline $9 / 19$ & Unnamed \#13 & Diamond Fork & Klickitat & 6.8 & $\mathrm{Bk}$ & 42 & north fork of trib. B \\
\hline $9 / 19$ & Unnamed \#13 & Diamond Fork & Klickitat & 6.8 & $\mathrm{Bk}$ & 133 & north fork of trib. B \\
\hline $10 / 23$ & Unnamed \#1 & White Salmon & White Salmon & 2.8 & $\mathrm{Rb}$ & 112 & 1st creek on $101 \mathrm{rd}$ \\
\hline $10 / 23$ & Unnamed \#1 & White Salmon & White Salmon & 2.8 & $\mathrm{Rb}$ & 96 & 1 st creek on $101 \mathrm{rd}$ \\
\hline $10 / 23$ & Unnamed \#1 & White Salmon & White Salmon & 2.8 & $\mathrm{Rb}$ & 88 & 1 st creek on $101 \mathrm{rd}$ \\
\hline $10 / 23$ & Unnamed \#1 & White Salmon & White Salmon & 2.8 & $\mathrm{Rb}$ & 160 & 1st creek on $101 \mathrm{rd}$ \\
\hline $10 / 23$ & Unnamed \#1 & White Salmon & White Salmon & 2.8 & $\mathrm{Rb}$ & 189 & 1st creek on $101 \mathrm{rd}$ \\
\hline $10 / 23$ & Unnamed \#1 & White Salmon & White Salmon & 2.8 & $\mathrm{Rb}$ & 178 & 1st creek on $101 \mathrm{rd}$ \\
\hline $10 / 23$ & Unnamed \#1 & White Salmon & White Salmon & 2.8 & $\mathrm{Rb}$ & 165 & 1 st creek on $101 \mathrm{rd}$ \\
\hline $10 / 23$ & Unnamed \#1 & White Salmon & White Salmon & 2.8 & $\mathrm{Rb}$ & 151 & 1 st creek on $101 \mathrm{rd}$ \\
\hline $10 / 23$ & Unnamed \#3 & White Salmon & White Salmon & 2.8 & $\mathrm{Rb}$ & 64 & 3rd creek on $101 \mathrm{rd}$ \\
\hline $10 / 23$ & Unnamed \#3 & White Salmon & White Salmon & 2.8 & $\mathrm{Rb}$ & 112 & 3rd creek on $101 \mathrm{rd}$ \\
\hline $10 / 23$ & Unnamed \#3 & White Salmon & White Salmon & 2.8 & $\mathrm{Rb}$ & 64 & 3rd creek on $101 \mathrm{rd}$ \\
\hline $10 / 23$ & Unnamed \#3 & White Salmon & White Salmon & 2.8 & $\mathrm{Rb}$ & 28 & 3rd creek on $101 \mathrm{rd}$ \\
\hline $10 / 23$ & Unnamed \#3 & White Salmon & White Salmon & 2.8 & $\mathrm{Rb}$ & 123 & 3rd creek on $101 \mathrm{rd}$ \\
\hline $10 / 23$ & Unnamed \#3 & White Salmon & White Salmon & 2.8 & $\mathrm{Rb}$ & 131 & 3rd creek on $101 \mathrm{rd}$ \\
\hline $10 / 23$ & Unnamed \#3 & White Salmon & White Salmon & 2.8 & $\mathrm{Rb}$ & 99 & 3rd creek on $101 \mathrm{rd}$ \\
\hline $10 / 23$ & Unnamed \#3 & White Salmon & White Salmon & 2.8 & $\mathrm{Rb}$ & 92 & 3rd creek on 101 rd \\
\hline $10 / 23$ & Unnamed \#5 & White Salmon & White Salmon & 2.8 & $\mathrm{Rb}$ & 131 & above bridge \\
\hline $10 / 23$ & Unnamed \#5 & White Salmon & White Salmon & 2.8 & $\mathrm{Rb}$ & 131 & below bridge \\
\hline $10 / 23$ & Unnamed \#5 & White Salmon & White Salmon & 2.8 & $\mathrm{Rb}$ & 185 & below bridge \\
\hline $10 / 24$ & Unnamed \#2 & White Salmon & White Salmon & 3.3 & $\mathrm{Rb}$ & 61 & 2nd creek on $101 \mathrm{rd}$ \\
\hline $10 / 24$ & Unnamed \#2 & White Salmon & White Salmon & 3.3 & $\mathrm{Rb}$ & 94 & 2nd creek on $101 \mathrm{rd}$ \\
\hline $10 / 24$ & Unnamed \#2 & White Salmon & White Salmon & 3.3 & $\mathrm{Rb}$ & 126 & 2nd creek on $101 \mathrm{rd}$ \\
\hline $10 / 24$ & Unnamed \#2 & White Salmon & White Salmon & 3.3 & $\mathrm{Rb}$ & 83 & 2nd creek on $101 \mathrm{rd}$ \\
\hline $10 / 24$ & Unnamed \#2 & White Salmon & White Salmon & 3.3 & $\mathrm{Rb}$ & 143 & 2nd creek on $101 \mathrm{rd}$ \\
\hline $10 / 24$ & Unnamed \#2 & White Salmon & White Salmon & 3.3 & $\mathrm{Rb}$ & 83 & 2nd creek on 101 rd \\
\hline $10 / 24$ & Unnamed \#2 & White Salmon & White Salmon & 3.3 & $\mathrm{Rb}$ & 87 & 2nd creek on $101 \mathrm{rd}$ \\
\hline
\end{tabular}


Appendix C. Electroshock data from streams in the Klickitat and White Salmon river basins, 2001.

\begin{tabular}{|c|c|c|c|c|c|c|c|}
\hline $10 / 24$ & Unnamed \#2 & White Salmon & White Salmon & 3.3 & $\mathrm{Rb}$ & 133 & 2nd creek on $101 \mathrm{rd}$ \\
\hline $10 / 24$ & Unnamed \#2 & White Salmon & White Salmon & 3.3 & $\mathrm{Rb}$ & 78 & 2nd creek on $101 \mathrm{rd}$ \\
\hline $10 / 24$ & Unnamed \#2 & White Salmon & White Salmon & 3.3 & $\mathrm{Rb}$ & 127 & 2nd creek on 101 rd \\
\hline $10 / 24$ & Unnamed \#2 & White Salmon & White Salmon & 3.3 & $\mathrm{Rb}$ & 117 & 2nd creek on $101 \mathrm{rd}$ \\
\hline $10 / 24$ & Unnamed \#2 & White Salmon & White Salmon & 3.3 & $\mathrm{Rb}$ & 62 & 2nd creek on $101 \mathrm{rd}$ \\
\hline $10 / 24$ & Unnamed \#2 & White Salmon & White Salmon & 3.3 & $\mathrm{Rb}$ & 89 & 2nd creek on $101 \mathrm{rd}$ \\
\hline $10 / 24$ & Unnamed \#2 & White Salmon & White Salmon & 3.3 & $\mathrm{Rb}$ & 82 & 2nd creek on $101 \mathrm{rd}$ \\
\hline $10 / 24$ & Unnamed \#2 & White Salmon & White Salmon & 3.3 & $\mathrm{Rb}$ & 102 & 2nd creek on $101 \mathrm{rd}$ \\
\hline $10 / 24$ & Unnamed \#2 & White Salmon & White Salmon & 3.3 & $\mathrm{Rb}$ & 84 & 2nd creek on 101 rd \\
\hline $10 / 24$ & Unnamed \#2 & White Salmon & White Salmon & 3.3 & $\mathrm{Rb}$ & 82 & 2nd creek on $101 \mathrm{rd}$ \\
\hline $10 / 24$ & Unnamed \#4 & White Salmon & White Salmon & 3.3 & $\mathrm{Rb}$ & 131 & 4th creek on $101 \mathrm{rd}$ \\
\hline $10 / 24$ & Unnamed \#4 & White Salmon & White Salmon & 3.3 & $\mathrm{Rb}$ & 150 & 4th creek on $101 \mathrm{rd}$ \\
\hline $10 / 24$ & Unnamed & White Salmon & \begin{tabular}{|l} 
White Salmon \\
\end{tabular} & 2.2 & $\mathrm{Rb}$ & 176 & 2nd creek past end of $101 \mathrm{rd}$ \\
\hline $10 / 30$ & Elmer Cyn. & White Salmon & White Salmon & 7.1 & & & Small creek off Trout Lake to Glenwood rd \\
\hline $9 / 25$ & Two Lakes & Two Lakes & Klickitat & 9 & $\mathrm{Rb}$ & 175 & Main creek out of Two Lakes (above falls) \\
\hline $9 / 25$ & Two Lakes & Two Lakes & Klickitat & 9 & $\mathrm{Rb}$ & 171 & Main creek out of Two Lakes (above falls) \\
\hline $9 / 25$ & Two Lakes & Two Lakes & Klickitat & 9 & $\mathrm{Rb}$ & 94 & Main creek out of Two Lakes (above falls) \\
\hline $9 / 25$ & Two Lakes & Two Lakes & Klickitat & 9 & $\mathrm{Rb}$ & 110 & Main creek out of Two Lakes (above falls) \\
\hline $9 / 25$ & Two Lakes & Two Lakes & Klickitat & 9 & $\mathrm{Rb}$ & 54 & Main creek out of Two Lakes (above falls) \\
\hline $9 / 25$ & Two Lakes & Two Lakes & Klickitat & 9 & $\mathrm{Rb}$ & 110 & Main creek out of Two Lakes (above falls) \\
\hline $9 / 25$ & Two Lakes & Two Lakes & Klickitat & 9 & $\mathrm{Rb}$ & 89 & Main creek out of Two Lakes (above falls) \\
\hline $9 / 25$ & Two Lakes & Two Lakes & Klickitat & 9 & $\mathrm{Rb}$ & 101 & Main creek out of Two Lakes (above falls) \\
\hline $9 / 25$ & Two Lakes & Two Lakes & Klickitat & 9 & $\mathrm{Rb}$ & 56 & Main creek out of Two Lakes (above falls) \\
\hline $9 / 25$ & Two Lakes & Two Lakes & Klickitat & 9 & $\mathrm{Rb}$ & 59 & Main creek out of Two Lakes (above falls) \\
\hline $9 / 25$ & Two Lakes & Two Lakes & Klickitat & 9 & $\mathrm{Rb}$ & 142 & Main creek out of Two Lakes (above falls) \\
\hline $9 / 25$ & Two Lakes & Two Lakes & Klickitat & 9 & $\mathrm{Rb}$ & 104 & Main creek out of Two Lakes (above falls) \\
\hline $9 / 25$ & Two Lakes & Two Lakes & Klickitat & 9 & $\mathrm{Rb}$ & 57 & Main creek out of Two Lakes (above falls) \\
\hline $9 / 25$ & Two Lakes & Two Lakes & Klickitat & 9 & $\mathrm{Rb}$ & 100 & Main creek out of Two Lakes (above falls) \\
\hline $9 / 25$ & Two Lakes & Two Lakes & Klickitat & 9 & $\mathrm{Rb}$ & 60 & Main creek out of Two Lakes (above falls) \\
\hline $9 / 25$ & Two Lakes & Two Lakes & Klickitat & 9 & $\mathrm{Rb}$ & 128 & Main creek out of Two Lakes (above falls) \\
\hline $9 / 25$ & Two Lakes & Two Lakes & Klickitat & 9 & $\mathrm{Rb}$ & 90 & Main creek out of Two Lakes (above falls) \\
\hline $9 / 25$ & Two Lakes & Two Lakes & Klickitat & 9 & $\mathrm{Rb}$ & 91 & Main creek out of Two Lakes (above falls) \\
\hline $9 / 25$ & Two Lakes & Two Lakes & Klickitat & 9 & $\mathrm{Rb}$ & 66 & Main creek out of Two Lakes (above falls) \\
\hline $9 / 25$ & Two Lakes & Two Lakes & Klickitat & 9 & $\mathrm{Rb}$ & 58 & Main creek out of Two Lakes (above falls) \\
\hline $9 / 25$ & Two Lakes & Two Lakes & Klickitat & 9 & $\mathrm{Rb}$ & 54 & Main creek out of Two Lakes (above falls) \\
\hline $9 / 25$ & Two Lakes & Two Lakes & Klickitat & 9 & $\mathrm{Rb}$ & 56 & Main creek out of Two Lakes (above falls) \\
\hline $9 / 25$ & Two Lakes & Two Lakes & Klickitat & 9 & $\mathrm{Rb}$ & 90 & Main creek out of Two Lakes (above falls) \\
\hline $9 / 25$ & Two Lakes & Two Lakes & Klickitat & 9 & $\mathrm{Rb}$ & 40 & Main creek out of Two Lakes (above falls) \\
\hline $9 / 25$ & Two Lakes & Two Lakes & Klickitat & 9 & $\mathrm{Rb}$ & 104 & Main creek out of Two Lakes (above falls) \\
\hline $9 / 25$ & Two Lakes & Two Lakes & Klickitat & 9 & $\mathrm{Rb}$ & 100 & Main creek out of Two Lakes (above falls) \\
\hline $9 / 25$ & Two Lakes & Two Lakes & Klickitat & 9 & $\mathrm{Rb}$ & 80 & Main creek out of Two Lakes (above falls) \\
\hline $9 / 25$ & Two Lakes & Two Lakes & Klickitat & 9 & $\mathrm{Rb}$ & 85 & Main creek out of Two Lakes (above falls) \\
\hline $9 / 25$ & Two Lakes & Two Lakes & Klickitat & 9 & $\mathrm{Rb}$ & 115 & Main creek out of Two Lakes (above falls) \\
\hline $9 / 25$ & Two Lakes & Two Lakes & Klickitat & 9 & $\mathrm{Rb}$ & 105 & Main creek out of Two Lakes (above falls) \\
\hline $9 / 25$ & Two Lakes & Two Lakes & Klickitat & 9 & $\mathrm{Rb}$ & 56 & Main creek out of Two Lakes (above falls) \\
\hline $9 / 25$ & Two Lakes & Two Lakes & Klickitat & 9 & $\mathrm{Rb}$ & 60 & Main creek out of Two Lakes (above falls) \\
\hline $9 / 25$ & Two Lakes & Two Lakes & Klickitat & 9 & $\mathrm{Rb}$ & 57 & Main creek out of Two Lakes (above falls) \\
\hline $9 / 25$ & Two Lakes & Two Lakes & Klickitat & 9 & $\mathrm{Rb}$ & 63 & Main creek out of Two Lakes (above falls) \\
\hline $9 / 25$ & Two Lakes & Two Lakes & Klickitat & 9 & $\mathrm{Rb}$ & 123 & Main creek out of Two Lakes (above falls) \\
\hline $9 / 25$ & Two Lakes & Two Lakes & Klickitat & 9 & $\mathrm{Rb}$ & 52 & Main creek out of Two Lakes (above falls) \\
\hline $9 / 25$ & Two Lakes & Two Lakes & Klickitat & 9 & $\mathrm{Rb}$ & 35 & Main creek out of Two Lakes (above falls) \\
\hline $9 / 25$ & Two Lakes & Two Lakes & Klickitat & 9 & $\mathrm{Rb}$ & 54 & Main creek out of Two Lakes (above falls) \\
\hline $9 / 25$ & Two Lakes & Two Lakes & Klickitat & 9 & $\mathrm{Rb}$ & 48 & Main creek out of Two Lakes (above falls) \\
\hline $9 / 25$ & Two Lakes & Two Lakes & Klickitat & 9 & $\mathrm{Rb}$ & 140 & Main creek out of Two Lakes (above falls) \\
\hline $9 / 25$ & Two Lakes & Two Lakes & Klickitat & 9 & $\mathrm{Rb}$ & 101 & Main creek out of Two Lakes (above falls) \\
\hline $9 / 25$ & Two Lakes & Two Lakes & Klickitat & 9 & $\mathrm{Rb}$ & 108 & Main creek out of Two Lakes (above falls) \\
\hline $9 / 25$ & Two Lakes & Two Lakes & Klickitat & 9 & $\mathrm{Rb}$ & 47 & Main creek out of Two Lakes (above falls) \\
\hline $9 / 25$ & Two Lakes & Two Lakes & Klickitat & 9 & $\mathrm{Rb}$ & 97 & Main creek out of Two Lakes (above falls) \\
\hline $9 / 25$ & Two Lakes & Two Lakes & Klickitat & 9 & $\mathrm{Rb}$ & 55 & Main creek out of Two Lakes (above falls) \\
\hline $9 / 25$ & Two Lakes & Two Lakes & Klickitat & 9 & $\mathrm{Rb}$ & 57 & Main creek out of Two Lakes (above falls) \\
\hline $9 / 25$ & Two Lakes & Two Lakes & Klickitat & 9 & $\mathrm{Rb}$ & 94 & Main creek out of Two Lakes (above falls) \\
\hline $9 / 25$ & Two Lakes & Two Lakes & Klickitat & 9 & $\mathrm{Rb}$ & 58 & Main creek out of Two Lakes (above falls) \\
\hline $9 / 25$ & Two Lakes & Two Lakes & Klickitat & 9 & $\mathrm{Rb}$ & 54 & Main creek out of Two Lakes (above falls) \\
\hline $9 / 25$ & Two Lakes & Two Lakes & Klickitat & 9 & $\mathrm{Rb}$ & 48 & Main creek out of Two Lakes (above falls) \\
\hline $9 / 25$ & Two Lakes & Two Lakes & Klickitat & 9 & $\mathrm{Rb}$ & 54 & Main creek out of Two Lakes (above falls) \\
\hline $9 / 25$ & Two Lakes & Two Lakes & Klickitat & 9 & $\mathrm{Rb}$ & 48 & Main creek out of Two Lakes (above falls) \\
\hline $9 / 25$ & Two Lakes & Two Lakes & Klickitat & 9 & $\mathrm{Rb}$ & 55 & Main creek out of Two Lakes (above falls) \\
\hline $9 / 25$ & Two Lakes & Two Lakes & Klickitat & 9 & $\mathrm{Rb}$ & 48 & Main creek out of Two Lakes (above falls) \\
\hline $9 / 25$ & Two Lakes & Two Lakes & Klickitat & 9 & $\mathrm{Rb}$ & 136 & Main creek out of Two Lakes (above falls) \\
\hline
\end{tabular}


Appendix C. Electroshock data from streams in the Klickitat and White Salmon river basins, 2001.

\begin{tabular}{|c|c|c|c|c|c|c|c|}
\hline $9 / 25$ & Two Lakes & Two Lakes & Klickitat & 9 & $\mathrm{Rb}$ & 53 & Main creek out of Two Lakes (above falls) \\
\hline $9 / 25$ & Two Lakes & Two Lakes & Klickitat & 9 & $\mathrm{Rb}$ & 58 & Main creek out of Two Lakes (above falls) \\
\hline 9/25 & Two Lakes & Two Lakes & Klickitat & 9 & $\mathrm{Rb}$ & 45 & Main creek out of Two Lakes (above falls) \\
\hline $9 / 25$ & Two Lakes & Two Lakes & Klickitat & 9 & $\mathrm{Rb}$ & 54 & Main creek out of Two Lakes (above falls) \\
\hline $9 / 25$ & Two Lakes & Two Lakes & Klickitat & 9 & $\mathrm{Rb}$ & 84 & Main creek out of Two Lakes (above falls) \\
\hline $9 / 25$ & Two Lakes & Two Lakes & Klickitat & 9 & $\mathrm{Rb}$ & 68 & Main creek out of Two Lakes (above falls) \\
\hline $9 / 25$ & Two Lakes & Two Lakes & Klickitat & 9 & $\mathrm{Rb}$ & 40 & Main creek out of Two Lakes (above falls) \\
\hline $9 / 25$ & Two Lakes & Two Lakes & Klickitat & 9 & $\mathrm{Rb}$ & 53 & Main creek out of Two Lakes (above falls) \\
\hline 9/25 & Two Lakes & Two Lakes & Klickitat & 9 & $\mathrm{Rb}$ & 55 & Main creek out of Two Lakes (above falls) \\
\hline 9/25 & Two Lakes & Two Lakes & Klickitat & 9 & $\mathrm{Rb}$ & 56 & Main creek out of Two Lakes (above falls) \\
\hline 9/25 & Two Lakes & Two Lakes & Klickitat & 9 & $\mathrm{Rb}$ & 52 & Main creek out of Two Lakes (above falls) \\
\hline $9 / 25$ & Two Lakes & Two Lakes & Klickitat & 9 & $\mathrm{Bk}$ & 108 & Main creek out of Two Lakes (above falls) \\
\hline $9 / 25$ & Two Lakes & Two Lakes & Klickitat & 9 & $\mathrm{Bk}$ & 115 & Main creek out of Two Lakes (above falls) \\
\hline $9 / 25$ & Two Lakes & Two Lakes & Klickitat & 9 & $\mathrm{Bk}$ & 110 & Main creek out of Two Lakes (above falls) \\
\hline 9/25 & Two Lakes & Two Lakes & Klickitat & 9 & $\mathrm{Bk}$ & 138 & Main creek out of Two Lakes (above falls) \\
\hline $9 / 25$ & Two Lakes & Two Lakes & Klickitat & 9 & Bk & 111 & Main creek out of Two Lakes (above falls) \\
\hline $9 / 25$ & Two Lakes & Two Lakes & Klickitat & 9 & $\mathrm{Bk}$ & 120 & Main creek out of Two Lakes (above falls) \\
\hline 9/25 & Two Lakes & Two Lakes & Klickitat & 9 & Bk & 120 & Main creek out of Two Lakes (above falls) \\
\hline 9/25 & Two Lakes & Two Lakes & Klickitat & 9 & $\mathrm{Bk}$ & 149 & Main creek out of Two Lakes (above falls) \\
\hline 9/25 & Two Lakes & Two Lakes & Klickitat & 9 & $\mathrm{Bk}$ & 142 & Main creek out of Two Lakes (above falls) \\
\hline 9/25 & Two Lakes & Two Lakes & Klickitat & 9 & $\mathrm{Bk}$ & 98 & Main creek out of Two Lakes (above falls) \\
\hline 9/25 & Two Lakes & Two Lakes & Klickitat & 9 & $\mathrm{Bk}$ & 107 & Main creek out of Two Lakes (above falls) \\
\hline $9 / 25$ & Two Lakes & Two Lakes & Klickitat & 9 & Bk & 75 & Main creek out of Two Lakes (above falls) \\
\hline $9 / 25$ & Two Lakes & Two Lakes & Klickitat & 9 & $\mathrm{Bk}$ & 113 & Main creek out of Two Lakes (above falls) \\
\hline $9 / 25$ & Two Lakes & Two Lakes & Klickitat & 9 & $\mathrm{Bk}$ & 93 & Main creek out of Two Lakes (above falls) \\
\hline $9 / 25$ & Two Lakes & Two Lakes & Klickitat & 9 & $\mathrm{Bk}$ & 118 & Main creek out of Two Lakes (above falls) \\
\hline $9 / 25$ & Two Lakes & Two Lakes & Klickitat & 9 & $\mathrm{Bk}$ & 131 & Main creek out of Two Lakes (above falls) \\
\hline $9 / 25$ & Two Lakes & Two Lakes & Klickitat & 9 & Bk & 120 & Main creek out of Two Lakes (above falls) \\
\hline $9 / 25$ & Two Lakes & Two Lakes & Klickitat & 9 & Bk & 109 & Main creek out of Two Lakes (above falls) \\
\hline $9 / 25$ & Two Lakes & Two Lakes & Klickitat & 9 & $\mathrm{Bk}$ & 131 & Main creek out of Two Lakes (above falls) \\
\hline $9 / 25$ & Two Lakes & Two Lakes & Klickitat & 9 & $\mathrm{Bk}$ & 138 & Main creek out of Two Lakes (above falls) \\
\hline $9 / 25$ & Two Lakes & Two Lakes & Klickitat & 9 & $\mathrm{Bk}$ & 128 & Main creek out of Two Lakes (above falls) \\
\hline $9 / 25$ & Two Lakes & Two Lakes & Klickitat & 9 & Bk & 132 & Main creek out of Two Lakes (above falls) \\
\hline 9/25 & Two Lakes & Two Lakes & Klickitat & 9 & $\mathrm{Bk}$ & 149 & Main creek out of Two Lakes (above falls) \\
\hline $9 / 25$ & Two Lakes & Two Lakes & Klickitat & 9 & $\mathrm{Bk}$ & 113 & Main creek out of Two Lakes (above falls) \\
\hline $9 / 25$ & Two Lakes & Two Lakes & Klickitat & 9 & Bk & 133 & Main creek out of Two Lakes (above falls) \\
\hline $9 / 25$ & Two Lakes & Two Lakes & Klickitat & 9 & $\mathrm{Bk}$ & 74 & Main creek out of Two Lakes (above falls) \\
\hline $9 / 25$ & Two Lakes & Two Lakes & Klickitat & 9 & Bk & 159 & Main creek out of Two Lakes (above falls) \\
\hline $9 / 25$ & Two Lakes & Two Lakes & Klickitat & 9 & Bk & 170 & Main creek out of Two Lakes (above falls) \\
\hline $9 / 25$ & Two Lakes & Two Lakes & Klickitat & 9 & Bk & 152 & Main creek out of Two Lakes (above falls) \\
\hline $9 / 25$ & Unnamed & Two Lakes & Klickitat & 4.5 & Bk & 56 & Unnamed trib. to Two Lakes Stream \\
\hline 9/25 & Unnamed & Two Lakes & Klickitat & 4.5 & $\mathrm{Bk}$ & 187 & Unnamed trib. to Two Lakes Stream \\
\hline 9/25 & Unnamed & Two Lakes & Klickitat & 4.5 & $\mathrm{Bk}$ & 48 & Unnamed trib. to Two Lakes Stream \\
\hline 9/25 & Unnamed & Two Lakes & Klickitat & 4.5 & Bk & 51 & Unnamed trib. to Two Lakes Stream \\
\hline $9 / 25$ & Unnamed & Two Lakes & Klickitat & 4.5 & Bk & 50 & Unnamed trib. to Two Lakes Stream \\
\hline 9/26 & Unnamed & Fish Lake & Klickitat & 8.5 & $\mathrm{Rb}$ & 114 & Unnamed trib. to Fish Lake Stream \\
\hline $9 / 26$ & Unnamed & Fish Lake & Klickitat & 8.5 & $\mathrm{Rb}$ & 148 & Unnamed trib. to Fish Lake Stream \\
\hline $9 / 26$ & Unnamed & Fish Lake & Klickitat & 8.5 & $\mathrm{Rb}$ & 147 & Unnamed trib. to Fish Lake Stream \\
\hline $9 / 26$ & Unnamed & Fish Lake & Klickitat & 8.5 & $\mathrm{Rb}$ & 135 & Unnamed trib. to Fish Lake Stream \\
\hline $9 / 26$ & Unnamed & Fish Lake & Klickitat & 8.5 & $\mathrm{Rb}$ & 177 & Unnamed trib. to Fish Lake Stream \\
\hline $9 / 26$ & Unnamed & Fish Lake & Klickitat & 8.5 & $\mathrm{Rb}$ & 306 & Unnamed trib. to Fish Lake Stream \\
\hline 9/26 & Unnamed & Fish Lake & Klickitat & 8.5 & $\mathrm{Bu}$ & 123 & Unnamed trib. to Fish Lake Stream \\
\hline $9 / 26$ & Unnamed & Fish Lake & Klickitat & 8.5 & $\mathrm{Bu}$ & 174 & Unnamed trib. to Fish Lake Stream \\
\hline $9 / 26$ & Unnamed & Fish Lake & Klickitat & 8.5 & $\mathrm{Bu}$ & 114 & Unnamed trib. to Fish Lake Stream \\
\hline $9 / 26$ & Unnamed & Fish Lake & Klickitat & 8.5 & $\mathrm{Bu}$ & 120 & Unnamed trib. to Fish Lake Stream \\
\hline $9 / 26$ & Unnamed & Fish Lake & Klickitat & 8.5 & $\mathrm{Bu}$ & 111 & Unnamed trib. to Fish Lake Stream \\
\hline 9/26 & Unnamed & Fish Lake & Klickitat & 8.5 & $\mathrm{Bu}$ & 151 & Unnamed trib. to Fish Lake Stream \\
\hline 9/26 & Unnamed & Cold Creek? & Klickitat & 5.6 & & & no fish, unnamed trib to Cold Creek? \\
\hline 9/26 & Yedlick & Klickitat & Klickitat & 10.5 & $\mathrm{Rb}$ & 107 & shocked upstream from culvert at road \\
\hline $9 / 26$ & Yedlick & Klickitat & Klickitat & 10.5 & $\mathrm{Rb}$ & 125 & shocked upstream from culvert at road \\
\hline $9 / 26$ & Yedlick & Klickitat & Klickitat & 10.5 & $\mathrm{Rb}$ & 85 & shocked upstream from culvert at road \\
\hline $9 / 26$ & Yedlick & Klickitat & Klickitat & 10.5 & $\mathrm{Rb}$ & 90 & shocked upstream from culvert at road \\
\hline $9 / 26$ & Yedlick & Klickitat & Klickitat & 10.5 & $\mathrm{Rb}$ & 90 & shocked upstream from culvert at road \\
\hline $9 / 26$ & Yedlick & Klickitat & Klickitat & 10.5 & $\mathrm{Rb}$ & 100 & shocked upstream from culvert at road \\
\hline $9 / 26$ & Yedlick & Klickitat & Klickitat & 10.5 & $\mathrm{Rb}$ & 90 & shocked upstream from culvert at road \\
\hline $9 / 26$ & Yedlick & Klickitat & Klickitat & 10.5 & $\mathrm{Rb}$ & 72 & shocked upstream from culvert at road \\
\hline $9 / 26$ & Yedlick & Klickitat & Klickitat & 10.5 & $\mathrm{Rb}$ & 69 & shocked upstream from culvert at road \\
\hline $9 / 26$ & Yedlick & Klickitat & Klickitat & 10.5 & $\mathrm{Rb}$ & 59 & shocked upstream from culvert at road \\
\hline $9 / 26$ & Yedlick & Klickitat & Klickitat & 10.5 & $\mathrm{Rb}$ & 98 & shocked upstream from culvert at road \\
\hline
\end{tabular}


Appendix C. Electroshock data from streams in the Klickitat and White Salmon river basins, 2001.

\begin{tabular}{|c|c|c|c|c|c|c|c|}
\hline $9 / 26$ & Yedlick & Klickitat & Klickitat & 10.5 & $\mathrm{Rb}$ & 141 & shocked upstream from culvert at road \\
\hline $9 / 26$ & Yedlick & Klickitat & Klickitat & 10.5 & $\mathrm{Rb}$ & 84 & shocked upstream from culvert at road \\
\hline $9 / 26$ & Yedlick & Klickitat & Klickitat & 10.5 & $\mathrm{Rb}$ & 112 & shocked upstream from culvert at road \\
\hline $9 / 26$ & Yedlick & Klickitat & Klickitat & 10.5 & $\mathrm{Rb}$ & 103 & shocked upstream from culvert at road \\
\hline $9 / 26$ & Yedlick & Klickitat & Klickitat & 10.5 & $\mathrm{Rb}$ & 100 & shocked upstream from culvert at road \\
\hline $9 / 26$ & Yedlick & Klickitat & Klickitat & 10.5 & $\mathrm{Rb}$ & 87 & shocked upstream from culvert at road \\
\hline $9 / 26$ & Yedlick & Klickitat & Klickitat & 10.5 & $\mathrm{Rb}$ & 147 & shocked upstream from culvert at road \\
\hline $9 / 26$ & Yedlick & Klickitat & Klickitat & 10.5 & $\mathrm{Rb}$ & 97 & shocked upstream from culvert at road \\
\hline $9 / 26$ & Yedlick & Klickitat & Klickitat & 10.5 & $\mathrm{Rb}$ & 125 & shocked upstream from culvert at road \\
\hline $9 / 26$ & Yedlick & Klickitat & Klickitat & 10.5 & $\mathrm{Rb}$ & 97 & shocked upstream from culvert at road \\
\hline $9 / 26$ & Yedlick & Klickitat & Klickitat & 10.5 & $\mathrm{Rb}$ & 148 & shocked upstream from culvert at road \\
\hline $9 / 26$ & Yedlick & Klickitat & Klickitat & 10.5 & $\mathrm{Rb}$ & 107 & shocked upstream from culvert at road \\
\hline $9 / 26$ & Yedlick & Klickitat & Klickitat & 10.5 & $\mathrm{Rb}$ & 100 & shocked upstream from culvert at road \\
\hline $9 / 26$ & Yedlick & Klickitat & Klickitat & 10.5 & $\mathrm{Rb}$ & 158 & shocked upstream from culvert at road \\
\hline $9 / 26$ & Yedlick & Klickitat & Klickitat & 10.5 & $\mathrm{Rb}$ & 174 & shocked upstream from culvert at road \\
\hline $9 / 26$ & Swamp & Klickitat & Klickitat & 10 & $\mathrm{Rb}$ & 145 & shocked at end of 251 Road \\
\hline $9 / 26$ & Swamp & Klickitat & Klickitat & 10 & $\mathrm{Rb}$ & 127 & shocked at end of 251 Road \\
\hline $9 / 26$ & Swamp & Klickitat & Klickitat & 10 & $\mathrm{Rb}$ & 110 & shocked at end of 251 Road \\
\hline $9 / 26$ & Swamp & Klickitat & Klickitat & 10 & $\mathrm{Rb}$ & 95 & shocked at end of 251 Road \\
\hline $9 / 26$ & Swamp & Klickitat & Klickitat & 10 & $\mathrm{Rb}$ & 143 & shocked at end of 251 Road \\
\hline $9 / 26$ & Swamp & Klickitat & Klickitat & 10 & $\mathrm{Rb}$ & 114 & shocked at end of 251 Road \\
\hline $9 / 26$ & Swamp & Klickitat & Klickitat & 10 & $\mathrm{Rb}$ & 97 & shocked at end of 251 Road \\
\hline $9 / 26$ & Swamp & Klickitat & Klickitat & 10 & $\mathrm{Rb}$ & 45 & shocked at end of 251 Road \\
\hline $9 / 26$ & Swamp & Klickitat & Klickitat & 10 & $\mathrm{Rb}$ & 120 & shocked at end of 251 Road \\
\hline $9 / 26$ & Swamp & Klickitat & Klickitat & 10 & $\mathrm{Rb}$ & 52 & shocked at end of 251 Road \\
\hline $9 / 26$ & Swamp & Klickitat & Klickitat & 10 & $\mathrm{Rb}$ & 39 & shocked at end of 251 Road \\
\hline $9 / 26$ & Swamp & Klickitat & Klickitat & 10 & $\mathrm{Rb}$ & 110 & shocked at end of 251 Road \\
\hline $9 / 26$ & Swamp & Klickitat & Klickitat & 10 & $\mathrm{Rb}$ & 110 & shocked at end of 251 Road \\
\hline $9 / 26$ & Swamp & Klickitat & Klickitat & 10 & $\mathrm{Rb}$ & 135 & shocked at end of 251 Road \\
\hline $9 / 26$ & Swamp & Klickitat & Klickitat & 10 & $\mathrm{Rb}$ & 108 & shocked at end of 251 Road \\
\hline $9 / 26$ & Swamp & Klickitat & Klickitat & 10 & $\mathrm{Rb}$ & 127 & shocked at end of 251 Road \\
\hline $9 / 26$ & Swamp & Klickitat & Klickitat & 10 & $\mathrm{Rb}$ & 119 & shocked at end of 251 Road \\
\hline $9 / 26$ & Swamp & Klickitat & Klickitat & 10 & $\mathrm{Rb}$ & 89 & shocked at end of 251 Road \\
\hline $9 / 26$ & Swamp & Klickitat & Klickitat & 10 & $\mathrm{Rb}$ & 85 & shocked at end of 251 Road \\
\hline $9 / 26$ & Swamp & Klickitat & Klickitat & 10 & $\mathrm{Rb}$ & 42 & shocked at end of 251 Road \\
\hline $9 / 26$ & Swamp & Klickitat & Klickitat & 10 & $\mathrm{Rb}$ & 47 & shocked at end of 251 Road \\
\hline $9 / 26$ & Swamp & Klickitat & Klickitat & 10 & $\mathrm{Rb}$ & 54 & shocked at end of 251 Road \\
\hline $9 / 26$ & Swamp & Klickitat & Klickitat & 10 & $\mathrm{Rb}$ & 83 & shocked at end of 251 Road \\
\hline $9 / 26$ & Swamp & Klickitat & Klickitat & 10 & $\mathrm{Rb}$ & 112 & shocked at end of 251 Road \\
\hline $9 / 26$ & Swamp & Klickitat & Klickitat & 10 & $\mathrm{Rb}$ & 112 & shocked at end of 251 Road \\
\hline $9 / 26$ & Swamp & Klickitat & Klickitat & 10 & $\mathrm{Rb}$ & 135 & shocked at end of 251 Road \\
\hline $9 / 26$ & Swamp & Klickitat & Klickitat & 10 & $\mathrm{Rb}$ & 120 & shocked at end of 251 Road \\
\hline 9/26 & Swamp & Klickitat & Klickitat & 10 & $\mathrm{Rb}$ & 85 & shocked at end of 251 Road \\
\hline $9 / 26$ & Swamp & Klickitat & Klickitat & 10 & $\mathrm{Rb}$ & 77 & shocked at end of 251 Road \\
\hline $9 / 26$ & Swamp & Klickitat & Klickitat & 10 & $\mathrm{Rb}$ & 139 & shocked at end of 251 Road \\
\hline $9 / 26$ & Swamp & Klickitat & Klickitat & 10 & $\mathrm{Rb}$ & 46 & shocked at end of 251 Road \\
\hline $9 / 26$ & Swamp & Klickitat & Klickitat & 10 & $\mathrm{Rb}$ & 44 & shocked at end of 251 Road \\
\hline $9 / 26$ & Swamp & Klickitat & Klickitat & 10 & $\mathrm{Rb}$ & 125 & shocked at end of 251 Road \\
\hline $9 / 26$ & Swamp & Klickitat & Klickitat & 10 & $\mathrm{Rb}$ & 94 & shocked at end of 251 Road \\
\hline $9 / 26$ & Swamp & Klickitat & Klickitat & 10 & $\mathrm{Rb}$ & 40 & shocked at end of 251 Road \\
\hline $9 / 26$ & Swamp & Klickitat & Klickitat & 10 & $\mathrm{Rb}$ & 164 & shocked at end of 251 Road \\
\hline $9 / 26$ & Swamp & Klickitat & Klickitat & 10 & $\mathrm{Rb}$ & 156 & shocked at end of 251 Road \\
\hline $9 / 26$ & Swamp & Klickitat & Klickitat & 10 & $\mathrm{Rb}$ & 170 & shocked at end of 251 Road \\
\hline $9 / 26$ & Swamp & Klickitat & Klickitat & 10 & $\mathrm{Rb}$ & 166 & shocked at end of 251 Road \\
\hline $9 / 26$ & Swamp & Klickitat & Klickitat & 10 & $\mathrm{Rb}$ & 162 & shocked at end of 251 Road \\
\hline $9 / 26$ & Swamp & Klickitat & Klickitat & 10 & $\mathrm{Rb}$ & 180 & shocked at end of 251 Road \\
\hline $9 / 26$ & Swamp & Klickitat & Klickitat & 10 & $\mathrm{Rb}$ & 175 & shocked at end of 251 Road \\
\hline $10 / 1$ & Howard Lake & Fish Lake & Klickitat & 7 & & & no fish, east fork of Howard Lake Stream \\
\hline $10 / 1$ & Howard Lake & Fish Lake & Klickitat & 6.7 & $\mathrm{Rb}$ & 142 & West fork of Howard Lake Stream \\
\hline $10 / 1$ & Howard Lake & Fish Lake & Klickitat & 6.7 & $\mathrm{Rb}$ & 83 & West fork of Howard Lake Stream \\
\hline $10 / 1$ & Howard Lake & Fish Lake & Klickitat & 6.7 & $\mathrm{Rb}$ & 118 & West fork of Howard Lake Stream \\
\hline $10 / 1$ & Howard Lake & Fish Lake & Klickitat & 6.7 & $\mathrm{Rb}$ & 135 & West fork of Howard Lake Stream \\
\hline $10 / 1$ & Howard Lake & Fish Lake & Klickitat & 6.7 & $\mathrm{Rb}$ & 88 & West fork of Howard Lake Stream \\
\hline $10 / 1$ & Howard Lake & Fish Lake & Klickitat & 6.7 & $\mathrm{Rb}$ & 89 & West fork of Howard Lake Stream \\
\hline $10 / 1$ & Howard Lake & Fish Lake & Klickitat & 6.7 & $\mathrm{Rb}$ & 71 & West fork of Howard Lake Stream \\
\hline $10 / 1$ & Howard Lake & Fish Lake & Klickitat & 6.7 & $\mathrm{Rb}$ & 167 & West fork of Howard Lake Stream \\
\hline $10 / 1$ & Howard Lake & Fish Lake & Klickitat & 6.7 & $\mathrm{Bk}$ & 125 & West fork of Howard Lake Stream \\
\hline $10 / 1$ & Howard Lake & Fish Lake & Klickitat & 6.7 & $\mathrm{Bk}$ & 71 & West fork of Howard Lake Stream \\
\hline $10 / 1$ & Howard Lake & Fish Lake & Klickitat & 6.7 & $\mathrm{Bk}$ & 79 & West fork of Howard Lake Stream \\
\hline
\end{tabular}


Appendix C. Electroshock data from streams in the Klickitat and White Salmon river basins, 2001.

\begin{tabular}{|c|c|c|c|c|c|c|c|}
\hline $10 / 1$ & Howard Lake & Fish Lake & Klickitat & 6.7 & $\mathrm{Bk}$ & 52 & West fork of Howard Lake Stream \\
\hline $10 / 1$ & Howard Lake & Fish Lake & Klickitat & 6.7 & $\mathrm{Bk}$ & 209 & West fork of Howard Lake Stream \\
\hline $10 / 2$ & Fish Lake & West Fork Klickitat & Klickitat & 10 & $\mathrm{Rb}$ & 123 & started about $1 / 4$ mi. below Fish Lake \\
\hline $10 / 2$ & Fish Lake & West Fork Klickitat & Klickitat & 10 & $\mathrm{Rb}$ & 125 & started about 1/4 mi. below Fish Lake \\
\hline $10 / 2$ & Fish Lake & West Fork Klickitat & Klickitat & 10 & $\mathrm{Rb}$ & 123 & started about $1 / 4$ mi. below Fish Lake \\
\hline $10 / 2$ & Fish Lake & West Fork Klickitat & Klickitat & 10 & $\mathrm{Rb}$ & 133 & started about 1/4 mi. below Fish Lake \\
\hline $10 / 2$ & Fish Lake & West Fork Klickitat & Klickitat & 10 & $\mathrm{Rb}$ & 88 & started about 1/4 mi. below Fish Lake \\
\hline $10 / 2$ & Fish Lake & West Fork Klickitat & Klickitat & 10 & $\mathrm{Rb}$ & 89 & started about $1 / 4$ mi. below Fish Lake \\
\hline $10 / 2$ & Fish Lake & West Fork Klickitat & Klickitat & 10 & $\mathrm{Rb}$ & 95 & started about $1 / 4$ mi. below Fish Lake \\
\hline $10 / 2$ & Fish Lake & West Fork Klickitat & Klickitat & 10 & $\mathrm{Rb}$ & 134 & started about $1 / 4$ mi. below Fish Lake \\
\hline $10 / 2$ & Fish Lake & West Fork Klickitat & Klickitat & 10 & $\mathrm{Rb}$ & 107 & started about 1/4 mi. below Fish Lake \\
\hline $10 / 2$ & Fish Lake & West Fork Klickitat & Klickitat & 10 & $\mathrm{Rb}$ & 106 & started about 1/4 mi. below Fish Lake \\
\hline $10 / 2$ & Fish Lake & West Fork Klickitat & Klickitat & 10 & $\mathrm{Rb}$ & 105 & started about 1/4 mi. below Fish Lake \\
\hline $10 / 2$ & Fish Lake & West Fork Klickitat & Klickitat & 10 & $\mathrm{Rb}$ & 113 & started about 1/4 mi. below Fish Lake \\
\hline $10 / 2$ & Fish Lake & West Fork Klickitat & Klickitat & 10 & $\mathrm{Rb}$ & 88 & started about 1/4 mi. below Fish Lake \\
\hline $10 / 2$ & Fish Lake & West Fork Klickitat & Klickitat & 10 & $\mathrm{Rb}$ & 135 & started about 1/4 mi. below Fish Lake \\
\hline $10 / 2$ & Fish Lake & West Fork Klickitat & Klickitat & 10 & $\mathrm{Rb}$ & 65 & started about $1 / 4$ mi. below Fish Lake \\
\hline $10 / 2$ & Fish Lake & West Fork Klickitat & Klickitat & 10 & $\mathrm{Rb}$ & 138 & started about 1/4 mi. below Fish Lake \\
\hline $10 / 2$ & Fish Lake & West Fork Klickitat & Klickitat & 10 & $\mathrm{Rb}$ & 97 & started about 1/4 mi. below Fish Lake \\
\hline $10 / 2$ & Fish Lake & West Fork Klickitat & Klickitat & 10 & $\mathrm{Rb}$ & 168 & started about 1/4 mi. below Fish Lake \\
\hline $10 / 2$ & Fish Lake & West Fork Klickitat & Klickitat & 10 & $\mathrm{Rb}$ & 90 & started about 1/4 mi. below Fish Lake \\
\hline $10 / 2$ & Fish Lake & West Fork Klickitat & Klickitat & 10 & $\mathrm{Rb}$ & 88 & started about 1/4 mi. below Fish Lake \\
\hline $10 / 2$ & Fish Lake & West Fork Klickitat & Klickitat & 10 & $\mathrm{Rb}$ & 117 & started about 1/4 mi. below Fish Lake \\
\hline $10 / 2$ & Fish Lake & West Fork Klickitat & Klickitat & 10 & $\mathrm{Rb}$ & 117 & started about 1/4 mi. below Fish Lake \\
\hline $10 / 2$ & Fish Lake & West Fork Klickitat & Klickitat & 10 & $\mathrm{Rb}$ & 133 & started about 1/4 mi. below Fish Lake \\
\hline $10 / 2$ & Fish Lake & West Fork Klickitat & Klickitat & 10 & $\mathrm{Rb}$ & 137 & started about 1/4 mi. below Fish Lake \\
\hline $10 / 2$ & Fish Lake & West Fork Klickitat & Klickitat & 10 & $\mathrm{Rb}$ & 92 & started about 1/4 mi. below Fish Lake \\
\hline $10 / 2$ & Fish Lake & West Fork Klickitat & Klickitat & 10 & $\mathrm{Rb}$ & 122 & started about 1/4 mi. below Fish Lake \\
\hline $10 / 2$ & Fish Lake & West Fork Klickitat & Klickitat & 10 & $\mathrm{Rb}$ & 94 & started about 1/4 mi. below Fish Lake \\
\hline $10 / 2$ & Fish Lake & West Fork Klickitat & Klickitat & 10 & $\mathrm{Rb}$ & 107 & started about 1/4 mi. below Fish Lake \\
\hline $10 / 2$ & Fish Lake & West Fork Klickitat & Klickitat & 10 & $\mathrm{Rb}$ & 103 & started about 1/4 mi. below Fish Lake \\
\hline $10 / 2$ & Fish Lake & West Fork Klickitat & Klickitat & 10 & $\mathrm{Rb}$ & 137 & started about 1/4 mi. below Fish Lake \\
\hline $10 / 2$ & Fish Lake & West Fork Klickitat & Klickitat & 10 & $\mathrm{Rb}$ & 105 & started about $1 / 4$ mi. below Fish Lake \\
\hline $10 / 2$ & Fish Lake & West Fork Klickitat & Klickitat & 10 & $\mathrm{Rb}$ & 138 & started about 1/4 mi. below Fish Lake \\
\hline $10 / 2$ & Fish Lake & West Fork Klickitat & Klickitat & 10 & $\mathrm{Rb}$ & 93 & started about 1/4 mi. below Fish Lake \\
\hline $10 / 2$ & Fish Lake & West Fork Klickitat & Klickitat & 10 & $\mathrm{Rb}$ & 101 & started about 1/4 mi. below Fish Lake \\
\hline $10 / 2$ & Fish Lake & West Fork Klickitat & Klickitat & 10 & $\mathrm{Rb}$ & 101 & started about 1/4 mi. below Fish Lake \\
\hline $10 / 2$ & Fish Lake & West Fork Klickitat & Klickitat & 10 & $\mathrm{Rb}$ & 88 & started about 1/4 mi. below Fish Lake \\
\hline $10 / 2$ & Fish Lake & West Fork Klickitat & Klickitat & 10 & $\mathrm{Rb}$ & 86 & started about 1/4 mi. below Fish Lake \\
\hline $10 / 2$ & Fish Lake & West Fork Klickitat & Klickitat & 10 & $\mathrm{Rb}$ & 100 & started about $1 / 4$ mi. below Fish Lake \\
\hline $10 / 2$ & Fish Lake & West Fork Klickitat & Klickitat & 10 & $\mathrm{Rb}$ & 92 & started about $1 / 4$ mi. below Fish Lake \\
\hline $10 / 2$ & Fish Lake & West Fork Klickitat & Klickitat & 10 & $\mathrm{Rb}$ & 105 & started about 1/4 mi. below Fish Lake \\
\hline $10 / 2$ & Fish Lake & West Fork Klickitat & Klickitat & 10 & $\mathrm{Rb}$ & 108 & started about 1/4 mi. below Fish Lake \\
\hline $10 / 2$ & Fish Lake & West Fork Klickitat & Klickitat & 10 & $\mathrm{Rb}$ & 94 & started about 1/4 mi. below Fish Lake \\
\hline $10 / 2$ & Fish Lake & West Fork Klickitat & Klickitat & 10 & $\mathrm{Rb}$ & 98 & started about $1 / 4 \mathrm{mi}$. below Fish Lake \\
\hline $10 / 2$ & Fish Lake & West Fork Klickitat & Klickitat & 10 & $\mathrm{Rb}$ & 105 & started about $1 / 4$ mi. below Fish Lake \\
\hline $10 / 2$ & Fish Lake & West Fork Klickitat & Klickitat & 10 & $\mathrm{Rb}$ & 82 & started about 1/4 mi. below Fish Lake \\
\hline $10 / 2$ & Fish Lake & West Fork Klickitat & Klickitat & 10 & $\mathrm{Rb}$ & 111 & started about 1/4 mi. below Fish Lake \\
\hline $10 / 2$ & Fish Lake & West Fork Klickitat & Klickitat & 10 & $\mathrm{Rb}$ & 88 & started about 1/4 mi. below Fish Lake \\
\hline $10 / 2$ & Fish Lake & West Fork Klickitat & Klickitat & 10 & $\mathrm{Rb}$ & 72 & started about 1/4 mi. below Fish Lake \\
\hline $10 / 2$ & Fish Lake & West Fork Klickitat & Klickitat & 10 & $\mathrm{Rb}$ & 85 & started about $1 / 4$ mi. below Fish Lake \\
\hline $10 / 2$ & Fish Lake & West Fork Klickitat & Klickitat & 10 & $\mathrm{Rb}$ & 107 & started about $1 / 4$ mi. below Fish Lake \\
\hline $10 / 2$ & Fish Lake & West Fork Klickitat & Klickitat & 10 & $\mathrm{Rb}$ & 112 & started about 1/4 mi. below Fish Lake \\
\hline $10 / 2$ & Fish Lake & West Fork Klickitat & Klickitat & 10 & $\mathrm{Rb}$ & 123 & started about $1 / 4$ mi. below Fish Lake \\
\hline $10 / 2$ & Fish Lake & West Fork Klickitat & Klickitat & 10 & $\mathrm{Rb}$ & 93 & started about $1 / 4$ mi. below Fish Lake \\
\hline $10 / 2$ & Fish Lake & West Fork Klickitat & Klickitat & 10 & $\mathrm{Rb}$ & 84 & started about $1 / 4$ mi. below Fish Lake \\
\hline $10 / 2$ & Fish Lake & West Fork Klickitat & Klickitat & 10 & $\mathrm{Rb}$ & 99 & started about 1/4 mi. below Fish Lake \\
\hline $10 / 2$ & Fish Lake & West Fork Klickitat & Klickitat & 10 & $\mathrm{Rb}$ & 101 & started about 1/4 mi. below Fish Lake \\
\hline $10 / 2$ & Fish Lake & West Fork Klickitat & Klickitat & 10 & $\mathrm{Rb}$ & 96 & started about 1/4 mi. below Fish Lake \\
\hline $10 / 2$ & Fish Lake & West Fork Klickitat & Klickitat & 10 & $\mathrm{Rb}$ & 119 & started about 1/4 mi. below Fish Lake \\
\hline $10 / 2$ & Fish Lake & West Fork Klickitat & Klickitat & 10 & $\mathrm{Rb}$ & 124 & started about $1 / 4$ mi. below Fish Lake \\
\hline $10 / 2$ & Fish Lake & West Fork Klickitat & Klickitat & 10 & $\mathrm{Rb}$ & 82 & started about 1/4 mi. below Fish Lake \\
\hline $10 / 2$ & Fish Lake & West Fork Klickitat & Klickitat & 10 & $\mathrm{Rb}$ & 137 & started about $1 / 4$ mi. below Fish Lake \\
\hline $10 / 2$ & Fish Lake & West Fork Klickitat & Klickitat & 10 & $\mathrm{Rb}$ & 133 & started about $1 / 4$ mi. below Fish Lake \\
\hline $10 / 2$ & Fish Lake & West Fork Klickitat & Klickitat & 10 & $\mathrm{Rb}$ & 100 & started about 1/4 mi. below Fish Lake \\
\hline $10 / 2$ & Fish Lake & West Fork Klickitat & Klickitat & 10 & $\mathrm{Rb}$ & 100 & started about $1 / 4$ mi. below Fish Lake \\
\hline $10 / 2$ & Fish Lake & West Fork Klickitat & \begin{tabular}{|l} 
Klickitat \\
\end{tabular} & 10 & $\mathrm{Rb}$ & 158 & started about $1 / 4 \mathrm{mi}$. below Fish Lake \\
\hline $10 / 2$ & Fish Lake & West Fork Klickitat & Klickitat & 10 & $\mathrm{Rb}$ & 108 & started about $1 / 4$ mi. below Fish Lake \\
\hline $10 / 2$ & Fish Lake & West Fork Klickitat & Klickitat & 10 & $\mathrm{Rb}$ & 92 & started about 1/4 mi. below Fish Lake \\
\hline
\end{tabular}


Appendix C. Electroshock data from streams in the Klickitat and White Salmon river basins, 2001.

\begin{tabular}{|c|c|c|c|c|c|c|c|}
\hline $10 / 2$ & Fish Lake & West Fork Klickitat & Klickitat & 10 & $\mathrm{Rb}$ & 123 & started about 1/4 mi. below Fish Lake \\
\hline $10 / 2$ & Fish Lake & West Fork Klickitat & Klickitat & 10 & $\mathrm{Rb}$ & 134 & started about $1 / 4$ mi. below Fish Lake \\
\hline $10 / 2$ & Fish Lake & West Fork Klickitat & Klickitat & 10 & $\mathrm{Rb}$ & 95 & started about $1 / 4 \mathrm{mi}$. below Fish Lake \\
\hline $10 / 2$ & Fish Lake & West Fork Klickitat & Klickitat & 10 & $\mathrm{Rb}$ & 97 & started about $1 / 4$ mi. below Fish Lake \\
\hline $10 / 2$ & Fish Lake & West Fork Klickitat & Klickitat & 10 & $\mathrm{Rb}$ & 91 & started about $1 / 4 \mathrm{mi}$. below Fish Lake \\
\hline $10 / 2$ & Fish Lake & West Fork Klickitat & Klickitat & 10 & $\mathrm{Rb}$ & 93 & started about 1/4 mi. below Fish Lake \\
\hline $10 / 2$ & Fish Lake & West Fork Klickitat & Klickitat & 10 & $\mathrm{Rb}$ & 98 & started about $1 / 4 \mathrm{mi}$. below Fish Lake \\
\hline $10 / 2$ & Fish Lake & West Fork Klickitat & Klickitat & 10 & $\mathrm{Rb}$ & 152 & started about $1 / 4 \mathrm{mi}$. below Fish Lake \\
\hline $10 / 2$ & Fish Lake & West Fork Klickitat & Klickitat & 10 & $\mathrm{Rb}$ & 112 & started about $1 / 4 \mathrm{mi}$. below Fish Lake \\
\hline $10 / 2$ & Fish Lake & West Fork Klickitat & Klickitat & 10 & $\mathrm{Rb}$ & 90 & started about $1 / 4 \mathrm{mi}$. below Fish Lake \\
\hline $10 / 2$ & Fish Lake & West Fork Klickitat & Klickitat & 10 & $\mathrm{Rb}$ & 122 & started about $1 / 4$ mi. below Fish Lake \\
\hline $10 / 2$ & Fish Lake & West Fork Klickitat & Klickitat & 10 & $\mathrm{Rb}$ & 98 & started about $1 / 4$ mi. below Fish Lake \\
\hline $10 / 2$ & Fish Lake & West Fork Klickitat & Klickitat & 10 & $\mathrm{Rb}$ & 91 & started about $1 / 4$ mi. below Fish Lake \\
\hline $10 / 2$ & Fish Lake & West Fork Klickitat & Klickitat & 10 & $\mathrm{Rb}$ & 98 & started about 1/4 mi. below Fish Lake \\
\hline $10 / 2$ & Fish Lake & West Fork Klickitat & Klickitat & 10 & $\mathrm{Rb}$ & 94 & started about $1 / 4$ mi. below Fish Lake \\
\hline $10 / 2$ & Fish Lake & West Fork Klickitat & Klickitat & 10 & $\mathrm{Rb}$ & 87 & started about $1 / 4$ mi. below Fish Lake \\
\hline $10 / 2$ & Fish Lake & West Fork Klickitat & Klickitat & 10 & $\mathrm{Rb}$ & 147 & started about $1 / 4$ mi. below Fish Lake \\
\hline $10 / 2$ & Fish Lake & West Fork Klickitat & Klickitat & 10 & $\mathrm{Rb}$ & 78 & started about 1/4 mi. below Fish Lake \\
\hline $10 / 2$ & Fish Lake & West Fork Klickitat & Klickitat & 10 & $\mathrm{Rb}$ & 102 & started about 1/4 mi. below Fish Lake \\
\hline $10 / 2$ & Fish Lake & West Fork Klickitat & Klickitat & 10 & $\mathrm{Rb}$ & 95 & started about $1 / 4$ mi. below Fish Lake \\
\hline $10 / 2$ & Fish Lake & West Fork Klickitat & Klickitat & 10 & $\mathrm{Rb}$ & 106 & started about $1 / 4$ mi. below Fish Lake \\
\hline $10 / 2$ & Fish Lake & West Fork Klickitat & Klickitat & 10 & $\mathrm{Rb}$ & 109 & started about $1 / 4$ mi. below Fish Lake \\
\hline $10 / 2$ & Fish Lake & West Fork Klickitat & Klickitat & 10 & $\mathrm{Rb}$ & 102 & started about $1 / 4 \mathrm{mi}$. below Fish Lake \\
\hline $10 / 2$ & Fish Lake & West Fork Klickitat & Klickitat & 10 & $\mathrm{Rb}$ & 96 & started about $1 / 4$ mi. below Fish Lake \\
\hline $10 / 2$ & Fish Lake & West Fork Klickitat & Klickitat & 10 & $\mathrm{Rb}$ & 94 & started about $1 / 4$ mi. below Fish Lake \\
\hline $10 / 2$ & Fish Lake & West Fork Klickitat & Klickitat & 10 & $\mathrm{Rb}$ & 112 & started about $1 / 4$ mi. below Fish Lake \\
\hline $10 / 2$ & Fish Lake & West Fork Klickitat & Klickitat & 10 & $\mathrm{Rb}$ & 118 & started about $1 / 4$ mi. below Fish Lake \\
\hline $10 / 2$ & Fish Lake & West Fork Klickitat & Klickitat & 10 & $\mathrm{Rb}$ & 141 & started about $1 / 4$ mi. below Fish Lake \\
\hline $10 / 2$ & Fish Lake & West Fork Klickitat & Klickitat & 10 & $\mathrm{Rb}$ & 97 & started about $1 / 4$ mi. below Fish Lake \\
\hline $10 / 2$ & Fish Lake & West Fork Klickitat & Klickitat & 10 & $\mathrm{Rb}$ & 112 & started about $1 / 4$ mi. below Fish Lake \\
\hline $10 / 2$ & Fish Lake & West Fork Klickitat & Klickitat & 10 & $\mathrm{Rb}$ & 142 & started about $1 / 4$ mi. below Fish Lake \\
\hline $10 / 2$ & Fish Lake & West Fork Klickitat & Klickitat & 10 & $\mathrm{Rb}$ & 106 & started about $1 / 4$ mi. below Fish Lake \\
\hline $10 / 2$ & Fish Lake & West Fork Klickitat & Klickitat & 10 & $\mathrm{Rb}$ & 117 & started about $1 / 4 \mathrm{mi}$. below Fish Lake \\
\hline $10 / 2$ & Fish Lake & West Fork Klickitat & Klickitat & 10 & $\mathrm{Rb}$ & 100 & started about $1 / 4$ mi. below Fish Lake \\
\hline $10 / 2$ & Fish Lake & West Fork Klickitat & Klickitat & 10 & $\mathrm{Rb}$ & 108 & started about $1 / 4$ mi. below Fish Lake \\
\hline $10 / 2$ & Fish Lake & West Fork Klickitat & Klickitat & 10 & $\mathrm{Rb}$ & 85 & started about $1 / 4$ mi. below Fish Lake \\
\hline $10 / 2$ & Fish Lake & West Fork Klickitat & Klickitat & 10 & $\mathrm{Rb}$ & 85 & started about $1 / 4$ mi. below Fish Lake \\
\hline $10 / 2$ & Fish Lake & West Fork Klickitat & Klickitat & 10 & $\mathrm{Rb}$ & 95 & started about $1 / 4$ mi. below Fish Lake \\
\hline $10 / 2$ & Fish Lake & West Fork Klickitat & Klickitat & 10 & $\mathrm{Rb}$ & 92 & started about $1 / 4$ mi. below Fish Lake \\
\hline $10 / 2$ & Fish Lake & West Fork Klickitat & Klickitat & 10 & $\mathrm{Rb}$ & 98 & started about $1 / 4 \mathrm{mi}$. below Fish Lake \\
\hline $10 / 2$ & Fish Lake & West Fork Klickitat & Klickitat & 10 & $\mathrm{Rb}$ & 97 & started about $1 / 4 \mathrm{mi}$. below Fish Lake \\
\hline $10 / 2$ & Fish Lake & West Fork Klickitat & Klickitat & 10 & $\mathrm{Rb}$ & 129 & started about $1 / 4$ mi. below Fish Lake \\
\hline $10 / 2$ & Fish Lake & West Fork Klickitat & Klickitat & 10 & $\mathrm{Bk}$ & 140 & started about 1/4 mi. below Fish Lake \\
\hline $10 / 2$ & Fish Lake & West Fork Klickitat & Klickitat & 10 & $\mathrm{Bk}$ & 132 & started about $1 / 4$ mi. below Fish Lake \\
\hline $10 / 2$ & Fish Lake & West Fork Klickitat & Klickitat & 10 & $\mathrm{Bk}$ & 66 & started about $1 / 4 \mathrm{mi}$. below Fish Lake \\
\hline $10 / 2$ & Fish Lake & West Fork Klickitat & Klickitat & 10 & $\mathrm{Bk}$ & 70 & started about $1 / 4 \mathrm{mi}$. below Fish Lake \\
\hline $10 / 2$ & Fish Lake & West Fork Klickitat & Klickitat & 10 & $\mathrm{Bk}$ & 65 & started about $1 / 4$ mi. below Fish Lake \\
\hline $10 / 2$ & Fish Lake & West Fork Klickitat & Klickitat & 10 & $\mathrm{Bk}$ & 67 & started about 1/4 mi. below Fish Lake \\
\hline $10 / 2$ & Fish Lake & West Fork Klickitat & Klickitat & 10 & $\mathrm{Bk}$ & 113 & started about $1 / 4$ mi. below Fish Lake \\
\hline $10 / 2$ & Fish Lake & West Fork Klickitat & Klickitat & 10 & Bk & 108 & started about $1 / 4$ mi. below Fish Lake \\
\hline $10 / 2$ & Fish Lake & West Fork Klickitat & Klickitat & 10 & $\mathrm{Bk}$ & 112 & started about $1 / 4 \mathrm{mi}$. below Fish Lake \\
\hline $10 / 2$ & Fish Lake & West Fork Klickitat & Klickitat & 10 & $\mathrm{Bk}$ & 66 & started about 1/4 mi. below Fish Lake \\
\hline $10 / 2$ & Fish Lake & West Fork Klickitat & Klickitat & 10 & $\mathrm{Bk}$ & 75 & started about $1 / 4$ mi. below Fish Lake \\
\hline $10 / 2$ & Fish Lake & West Fork Klickitat & Klickitat & 10 & $\mathrm{Bk}$ & 63 & started about 1/4 mi. below Fish Lake \\
\hline $10 / 2$ & Fish Lake & West Fork Klickitat & Klickitat & 10 & $\mathrm{Bk}$ & 145 & started about $1 / 4 \mathrm{mi}$. below Fish Lake \\
\hline $10 / 2$ & Fish Lake & West Fork Klickitat & Klickitat & 10 & $\mathrm{Bk}$ & 103 & started about 1/4 mi. below Fish Lake \\
\hline $10 / 2$ & Fish Lake & West Fork Klickitat & Klickitat & 10 & $\mathrm{Bk}$ & 138 & started about 1/4 mi. below Fish Lake \\
\hline $10 / 2$ & Fish Lake & West Fork Klickitat & Klickitat & 10 & $\mathrm{Bk}$ & 119 & started about $1 / 4$ mi. below Fish Lake \\
\hline $10 / 2$ & Fish Lake & West Fork Klickitat & Klickitat & 10 & $\mathrm{Bk}$ & 60 & started about $1 / 4$ mi. below Fish Lake \\
\hline $10 / 2$ & Fish Lake & West Fork Klickitat & Klickitat & 10 & $\mathrm{Bk}$ & 54 & started about $1 / 4$ mi. below Fish Lake \\
\hline $10 / 2$ & Fish Lake & West Fork Klickitat & Klickitat & 10 & $\mathrm{Bk}$ & 59 & started about $1 / 4 \mathrm{mi}$. below Fish Lake \\
\hline $10 / 2$ & Fish Lake & West Fork Klickitat & Klickitat & 10 & $\mathrm{Bk}$ & 101 & started about $1 / 4 \mathrm{mi}$. below Fish Lake \\
\hline $10 / 2$ & Fish Lake & West Fork Klickitat & Klickitat & 10 & $\mathrm{Bk}$ & 153 & started about $1 / 4 \mathrm{mi}$. below Fish Lake \\
\hline $10 / 2$ & Fish Lake & West Fork Klickitat & Klickitat & 10 & Bk & 112 & started about $1 / 4 \mathrm{mi}$. below Fish Lake \\
\hline $10 / 2$ & Fish Lake & West Fork Klickitat & Klickitat & 10 & $\mathrm{Bk}$ & 63 & started about $1 / 4$ mi. below Fish Lake \\
\hline $10 / 2$ & Fish Lake & West Fork Klickitat & Klickitat & 10 & Bk & 53 & started about $1 / 4 \mathrm{mi}$. below Fish Lake \\
\hline $10 / 2$ & Fish Lake & West Fork Klickitat & Klickitat & 10 & $\mathrm{Bk}$ & 107 & started about $1 / 4 \mathrm{mi}$. below Fish Lake \\
\hline $10 / 2$ & Fish Lake & West Fork Klickitat & \begin{tabular}{|l|} 
Klickitat \\
\end{tabular} & 10 & $\mathrm{Bk}$ & 77 & started about $1 / 4 \mathrm{mi}$. below Fish Lake \\
\hline $10 / 2$ & Fish Lake & West Fork Klickitat & Klickitat & 10 & $\mathrm{Bk}$ & 106 & started about $1 / 4$ mi. below Fish Lake \\
\hline
\end{tabular}


Appendix C. Electroshock data from streams in the Klickitat and White Salmon river basins, 2001.

\begin{tabular}{|c|c|c|c|c|c|c|c|}
\hline $10 / 2$ & Fish Lake & West Fork Klickitat & Klickitat & 10 & $\mathrm{Bk}$ & 184 & started about $1 / 4$ mi. below Fish Lake \\
\hline $10 / 2$ & Fish Lake & West Fork Klickitat & Klickitat & 10 & $\mathrm{Bk}$ & 143 & started about $1 / 4 \mathrm{mi}$. below Fish Lake \\
\hline $10 / 2$ & Fish Lake & West Fork Klickitat & Klickitat & 10 & $\mathrm{Bk}$ & 67 & started about 1/4 mi. below Fish Lake \\
\hline $10 / 2$ & Fish Lake & West Fork Klickitat & Klickitat & 10 & Bk & 104 & started about $1 / 4 \mathrm{mi}$. below Fish Lake \\
\hline $10 / 2$ & Fish Lake & West Fork Klickitat & Klickitat & 10 & $\mathrm{Bk}$ & 73 & started about $1 / 4 \mathrm{mi}$. below Fish Lake \\
\hline $10 / 2$ & Fish Lake & West Fork Klickitat & Klickitat & 10 & Bk & 67 & started about $1 / 4 \mathrm{mi}$. below Fish Lake \\
\hline $10 / 2$ & Fish Lake & West Fork Klickitat & Klickitat & 10 & Bk & 132 & started about $1 / 4 \mathrm{mi}$. below Fish Lake \\
\hline $10 / 2$ & Fish Lake & West Fork Klickitat & Klickitat & 10 & $\mathrm{Bk}$ & 56 & started about $1 / 4 \mathrm{mi}$. below Fish Lake \\
\hline $10 / 2$ & Fish Lake & West Fork Klickitat & Klickitat & 10 & $\mathrm{Bk}$ & 54 & started about $1 / 4 \mathrm{mi}$. below Fish Lake \\
\hline $10 / 2$ & Fish Lake & West Fork Klickitat & Klickitat & 10 & Bk & 175 & started about 1/4 mi. below Fish Lake \\
\hline $10 / 2$ & Fish Lake & West Fork Klickitat & Klickitat & 10 & $\mathrm{Bk}$ & 124 & started about $1 / 4 \mathrm{mi}$. below Fish Lake \\
\hline $10 / 2$ & Fish Lake & West Fork Klickitat & Klickitat & 10 & Bk & 140 & started about $1 / 4 \mathrm{mi}$. below Fish Lake \\
\hline $10 / 2$ & Fish Lake & West Fork Klickitat & Klickitat & 10 & Bk & 112 & started about $1 / 4 \mathrm{mi}$. below Fish Lake \\
\hline $10 / 2$ & Fish Lake & West Fork Klickitat & Klickitat & 10 & $\mathrm{Bk}$ & 115 & started about $1 / 4 \mathrm{mi}$. below Fish Lake \\
\hline $10 / 2$ & Fish Lake & West Fork Klickitat & Klickitat & 10 & Bk & 69 & started about $1 / 4 \mathrm{mi}$. below Fish Lake \\
\hline $10 / 2$ & Fish Lake & West Fork Klickitat & Klickitat & 10 & $\mathrm{Bk}$ & 105 & started about $1 / 4 \mathrm{mi}$. below Fish Lake \\
\hline $10 / 2$ & Fish Lake & West Fork Klickitat & Klickitat & 10 & $\mathrm{Bk}$ & 148 & started about $1 / 4 \mathrm{mi}$. below Fish Lake \\
\hline $10 / 2$ & Fish Lake & West Fork Klickitat & Klickitat & 10 & Bk & 77 & started about $1 / 4 \mathrm{mi}$. below Fish Lake \\
\hline $10 / 2$ & Fish Lake & West Fork Klickitat & Klickitat & 10 & $\mathrm{Bk}$ & 76 & started about $1 / 4 \mathrm{mi}$. below Fish Lake \\
\hline $10 / 2$ & Fish Lake & West Fork Klickitat & Klickitat & 10 & $\mathrm{Bk}$ & 81 & started about $1 / 4 \mathrm{mi}$. below Fish Lake \\
\hline $10 / 2$ & Fish Lake & West Fork Klickitat & Klickitat & 10 & Bk & 125 & started about $1 / 4 \mathrm{mi}$. below Fish Lake \\
\hline $10 / 2$ & Fish Lake & West Fork Klickitat & Klickitat & 10 & $\mathrm{Bk}$ & 125 & started about $1 / 4$ mi. below Fish Lake \\
\hline $10 / 2$ & Fish Lake & West Fork Klickitat & Klickitat & 10 & Bk & 71 & started about $1 / 4 \mathrm{mi}$. below Fish Lake \\
\hline $10 / 2$ & Fish Lake & West Fork Klickitat & Klickitat & 10 & Bk & 68 & started about $1 / 4 \mathrm{mi}$. below Fish Lake \\
\hline $10 / 2$ & Fish Lake & West Fork Klickitat & Klickitat & 10 & $\mathrm{Bk}$ & 65 & started about $1 / 4 \mathrm{mi}$. below Fish Lake \\
\hline $10 / 2$ & Fish Lake & West Fork Klickitat & Klickitat & 10 & Bk & 74 & started about $1 / 4 \mathrm{mi}$. below Fish Lake \\
\hline $10 / 2$ & Fish Lake & West Fork Klickitat & Klickitat & 10 & Bk & 117 & started about $1 / 4 \mathrm{mi}$. below Fish Lake \\
\hline $10 / 2$ & Fish Lake & West Fork Klickitat & Klickitat & 10 & $\mathrm{Bk}$ & 116 & started about $1 / 4 \mathrm{mi}$. below Fish Lake \\
\hline $10 / 2$ & Fish Lake & West Fork Klickitat & Klickitat & 10 & Bk & 174 & started about $1 / 4 \mathrm{mi}$. below Fish Lake \\
\hline $10 / 2$ & Fish Lake & West Fork Klickitat & Klickitat & 10 & $\mathrm{Bk}$ & 67 & started about $1 / 4 \mathrm{mi}$. below Fish Lake \\
\hline $10 / 2$ & Fish Lake & West Fork Klickitat & Klickitat & 10 & Bk & 127 & started about $1 / 4 \mathrm{mi}$. below Fish Lake \\
\hline $10 / 2$ & Fish Lake & West Fork Klickitat & Klickitat & 10 & $\mathrm{Bk}$ & 119 & started about $1 / 4 \mathrm{mi}$. below Fish Lake \\
\hline $10 / 2$ & Fish Lake & West Fork Klickitat & Klickitat & 10 & Bk & 97 & started about $1 / 4 \mathrm{mi}$. below Fish Lake \\
\hline $10 / 2$ & Fish Lake & West Fork Klickitat & Klickitat & 10 & $\mathrm{Bk}$ & 129 & started about $1 / 4 \mathrm{mi}$. below Fish Lake \\
\hline $10 / 2$ & Fish Lake & West Fork Klickitat & Klickitat & 10 & Bk & 100 & started about $1 / 4 \mathrm{mi}$. below Fish Lake \\
\hline $10 / 2$ & Fish Lake & West Fork Klickitat & Klickitat & 10 & Bk & 113 & started about $1 / 4 \mathrm{mi}$. below Fish Lake \\
\hline $10 / 2$ & Fish Lake & West Fork Klickitat & Klickitat & 10 & Bk & 83 & started about $1 / 4 \mathrm{mi}$. below Fish Lake \\
\hline $10 / 2$ & Fish Lake & West Fork Klickitat & Klickitat & 10 & Bk & 75 & started about $1 / 4 \mathrm{mi}$. below Fish Lake \\
\hline $10 / 2$ & Fish Lake & West Fork Klickitat & Klickitat & 10 & $\mathrm{Bk}$ & 158 & started about $1 / 4 \mathrm{mi}$. below Fish Lake \\
\hline $10 / 2$ & Fish Lake & West Fork Klickitat & Klickitat & 10 & $\mathrm{Bk}$ & 126 & started about $1 / 4 \mathrm{mi}$. below Fish Lake \\
\hline $10 / 2$ & Fish Lake & West Fork Klickitat & Klickitat & 10 & Bk & 60 & started about $1 / 4 \mathrm{mi}$. below Fish Lake \\
\hline $10 / 2$ & Fish Lake & West Fork Klickitat & Klickitat & 10 & Bk & 53 & started about 1/4 mi. below Fish Lake \\
\hline $10 / 2$ & Fish Lake & West Fork Klickitat & Klickitat & 10 & Bk & 129 & started about 1/4 mi. below Fish Lake \\
\hline $10 / 2$ & Fish Lake & West Fork Klickitat & Klickitat & 10 & Bk & 72 & started about $1 / 4 \mathrm{mi}$. below Fish Lake \\
\hline $10 / 2$ & Fish Lake & West Fork Klickitat & Klickitat & 10 & $\mathrm{Bk}$ & 126 & started about $1 / 4 \mathrm{mi}$. below Fish Lake \\
\hline $10 / 2$ & Fish Lake & West Fork Klickitat & Klickitat & 10 & $\mathrm{Bk}$ & 119 & started about $1 / 4 \mathrm{mi}$. below Fish Lake \\
\hline $10 / 2$ & Fish Lake & West Fork Klickitat & Klickitat & 10 & $\mathrm{Bk}$ & 105 & started about $1 / 4 \mathrm{mi}$. below Fish Lake \\
\hline $10 / 2$ & Fish Lake & West Fork Klickitat & Klickitat & 10 & Bk & 84 & started about $1 / 4 \mathrm{mi}$. below Fish Lake \\
\hline $10 / 2$ & Fish Lake & West Fork Klickitat & Klickitat & 10 & $\mathrm{Bk}$ & 104 & started about 1/4 mi. below Fish Lake \\
\hline $10 / 2$ & Fish Lake & West Fork Klickitat & Klickitat & 10 & $\mathrm{Bk}$ & 65 & started about $1 / 4 \mathrm{mi}$. below Fish Lake \\
\hline $10 / 2$ & Fish Lake & West Fork Klickitat & Klickitat & 10 & $\mathrm{Bk}$ & 108 & started about $1 / 4 \mathrm{mi}$. below Fish Lake \\
\hline $10 / 2$ & Fish Lake & West Fork Klickitat & Klickitat & 10 & Bk & 62 & started about $1 / 4 \mathrm{mi}$. below Fish Lake \\
\hline $10 / 2$ & Fish Lake & West Fork Klickitat & Klickitat & 10 & $\mathrm{Bk}$ & 148 & started about $1 / 4 \mathrm{mi}$. below Fish Lake \\
\hline $10 / 2$ & Fish Lake & West Fork Klickitat & \begin{tabular}{|l} 
Klickitat \\
\end{tabular} & 10 & $\mathrm{Bk}$ & 71 & started about $1 / 4 \mathrm{mi}$. below Fish Lake \\
\hline $10 / 2$ & Fish Lake & West Fork Klickitat & \begin{tabular}{|l} 
Klickitat \\
\end{tabular} & 10 & $\mathrm{Bk}$ & 100 & started about $1 / 4 \mathrm{mi}$. below Fish Lake \\
\hline $10 / 2$ & Fish Lake & West Fork Klickitat & Klickitat & 10 & $\mathrm{Bk}$ & 117 & started about 1/4 mi. below Fish Lake \\
\hline $10 / 2$ & Fish Lake & West Fork Klickitat & Klickitat & 10 & $\mathrm{Bk}$ & 92 & started about 1/4 mi. below Fish Lake \\
\hline $10 / 2$ & Fish Lake & West Fork Klickitat & Klickitat & 10 & Bk & 115 & started about $1 / 4 \mathrm{mi}$. below Fish Lake \\
\hline $10 / 2$ & Fish Lake & West Fork Klickitat & Klickitat & 10 & $\mathrm{Bk}$ & 67 & started about $1 / 4 \mathrm{mi}$. below Fish Lake \\
\hline $10 / 2$ & Fish Lake & West Fork Klickitat & Klickitat & 10 & $\mathrm{Bk}$ & 88 & started about $1 / 4 \mathrm{mi}$. below Fish Lake \\
\hline $10 / 2$ & Fish Lake & West Fork Klickitat & Klickitat & 10 & $\mathrm{Bk}$ & 62 & started about $1 / 4 \mathrm{mi}$. below Fish Lake \\
\hline $10 / 2$ & Fish Lake & West Fork Klickitat & Klickitat & 10 & $\mathrm{Bk}$ & 67 & started about $1 / 4 \mathrm{mi}$. below Fish Lake \\
\hline $10 / 2$ & Fish Lake & West Fork Klickitat & Klickitat & 10 & Bk & 64 & started about $1 / 4 \mathrm{mi}$. below Fish Lake \\
\hline $10 / 2$ & Fish Lake & West Fork Klickitat & Klickitat & 10 & Bk & 117 & started about $1 / 4 \mathrm{mi}$. below Fish Lake \\
\hline $10 / 2$ & Fish Lake & West Fork Klickitat & Klickitat & 10 & Bk & 133 & started about $1 / 4 \mathrm{mi}$. below Fish Lake \\
\hline $10 / 2$ & Fish Lake & West Fork Klickitat & Klickitat & 10 & Bk & 97 & started about 1/4 mi. below Fish Lake \\
\hline $10 / 2$ & Fish Lake & \begin{tabular}{|l|} 
West Fork Klickitat \\
\end{tabular} & Klickitat & 10 & Bk & 70 & started about 1/4 mi. below Fish Lake \\
\hline $10 / 2$ & Fish Lake & West Fork Klickitat & Klickitat & 10 & $\mathrm{Bk}$ & 104 & started about $1 / 4 \mathrm{mi}$. below Fish Lake \\
\hline $10 / 2$ & Fish Lake & West Fork Klickitat & Klickitat & 10 & Bk & 110 & started about $1 / 4 \mathrm{mi}$. below Fish Lake \\
\hline
\end{tabular}


Appendix C. Electroshock data from streams in the Klickitat and White Salmon river basins, 2001.

\begin{tabular}{|c|c|c|c|c|c|c|c|}
\hline $10 / 2$ & Fish Lake & West Fork Klickitat & Klickitat & 10 & $\mathrm{Bk}$ & 84 & started about 1/4 mi. below Fish Lake \\
\hline $10 / 2$ & Fish Lake & West Fork Klickitat & Klickitat & 10 & $\mathrm{Bk}$ & 135 & started about $1 / 4$ mi. below Fish Lake \\
\hline $10 / 2$ & Fish Lake & West Fork Klickitat & Klickitat & 10 & $\mathrm{Bk}$ & 119 & started about $1 / 4 \mathrm{mi}$. below Fish Lake \\
\hline $10 / 2$ & Fish Lake & West Fork Klickitat & Klickitat & 10 & $\mathrm{Bk}$ & 105 & started about $1 / 4$ mi. below Fish Lake \\
\hline $10 / 2$ & Fish Lake & West Fork Klickitat & Klickitat & 10 & Bk & 67 & started about $1 / 4 \mathrm{mi}$. below Fish Lake \\
\hline $10 / 2$ & Fish Lake & West Fork Klickitat & Klickitat & 10 & Bk & 130 & started about 1/4 mi. below Fish Lake \\
\hline $10 / 2$ & Fish Lake & West Fork Klickitat & Klickitat & 10 & $\mathrm{Bk}$ & 89 & started about $1 / 4$ mi. below Fish Lake \\
\hline $10 / 2$ & Fish Lake & West Fork Klickitat & Klickitat & 10 & Bk & 158 & started about $1 / 4 \mathrm{mi}$. below Fish Lake \\
\hline $10 / 2$ & Fish Lake & West Fork Klickitat & Klickitat & 10 & Bk & 114 & started about $1 / 4 \mathrm{mi}$. below Fish Lake \\
\hline $10 / 2$ & Fish Lake & West Fork Klickitat & Klickitat & 10 & Bk & 112 & started about $1 / 4 \mathrm{mi}$. below Fish Lake \\
\hline $10 / 2$ & Fish Lake & West Fork Klickitat & Klickitat & 10 & $\mathrm{Bk}$ & 69 & started about $1 / 4$ mi. below Fish Lake \\
\hline $10 / 2$ & Fish Lake & West Fork Klickitat & Klickitat & 10 & $\mathrm{Bk}$ & 57 & started about $1 / 4$ mi. below Fish Lake \\
\hline $10 / 2$ & Fish Lake & West Fork Klickitat & Klickitat & 10 & $\mathrm{Bk}$ & 117 & started about $1 / 4$ mi. below Fish Lake \\
\hline $10 / 2$ & Fish Lake & West Fork Klickitat & Klickitat & 10 & $\mathrm{Bk}$ & 162 & started about 1/4 mi. below Fish Lake \\
\hline $10 / 2$ & Fish Lake & West Fork Klickitat & Klickitat & 10 & $\mathrm{Bk}$ & 126 & started about $1 / 4$ mi. below Fish Lake \\
\hline $10 / 2$ & Fish Lake & West Fork Klickitat & Klickitat & 10 & $\mathrm{Bk}$ & 74 & started about $1 / 4$ mi. below Fish Lake \\
\hline $10 / 2$ & Fish Lake & West Fork Klickitat & Klickitat & 10 & $\mathrm{Bk}$ & 116 & started about $1 / 4 \mathrm{mi}$. below Fish Lake \\
\hline $10 / 2$ & Fish Lake & West Fork Klickitat & Klickitat & 10 & Bk & 101 & started about 1/4 mi. below Fish Lake \\
\hline $10 / 2$ & Fish Lake & West Fork Klickitat & Klickitat & 10 & Bk & 60 & started about 1/4 mi. below Fish Lake \\
\hline $10 / 2$ & Fish Lake & West Fork Klickitat & Klickitat & 10 & $\mathrm{Bk}$ & 64 & started about $1 / 4$ mi. below Fish Lake \\
\hline $10 / 2$ & Fish Lake & West Fork Klickitat & Klickitat & 10 & $\mathrm{Bk}$ & 64 & started about $1 / 4$ mi. below Fish Lake \\
\hline $10 / 2$ & Fish Lake & West Fork Klickitat & Klickitat & 10 & $\mathrm{Bk}$ & 67 & started about $1 / 4$ mi. below Fish Lake \\
\hline $10 / 2$ & Fish Lake & West Fork Klickitat & Klickitat & 10 & $\mathrm{Bk}$ & 100 & started about $1 / 4 \mathrm{mi}$. below Fish Lake \\
\hline $10 / 2$ & Fish Lake & West Fork Klickitat & Klickitat & 10 & $\mathrm{Bk}$ & 120 & started about $1 / 4 \mathrm{mi}$. below Fish Lake \\
\hline $10 / 2$ & Fish Lake & West Fork Klickitat & Klickitat & 10 & $\mathrm{Bk}$ & 164 & started about $1 / 4$ mi. below Fish Lake \\
\hline $10 / 2$ & Fish Lake & West Fork Klickitat & Klickitat & 10 & $\mathrm{Bk}$ & 110 & started about $1 / 4$ mi. below Fish Lake \\
\hline $10 / 2$ & Fish Lake & West Fork Klickitat & Klickitat & 10 & $\mathrm{Bk}$ & 112 & started about $1 / 4$ mi. below Fish Lake \\
\hline $10 / 2$ & Fish Lake & West Fork Klickitat & Klickitat & 10 & $\mathrm{Bk}$ & 64 & started about $1 / 4$ mi. below Fish Lake \\
\hline $10 / 2$ & Fish Lake & West Fork Klickitat & Klickitat & 10 & Bk & 117 & started about $1 / 4 \mathrm{mi}$. below Fish Lake \\
\hline $10 / 2$ & Fish Lake & West Fork Klickitat & Klickitat & 10 & $\mathrm{Bk}$ & 128 & started about $1 / 4$ mi. below Fish Lake \\
\hline $10 / 2$ & Fish Lake & West Fork Klickitat & Klickitat & 10 & $\mathrm{Bk}$ & 104 & started about $1 / 4$ mi. below Fish Lake \\
\hline $10 / 2$ & Fish Lake & West Fork Klickitat & Klickitat & 10 & $\mathrm{Bk}$ & 94 & started about $1 / 4$ mi. below Fish Lake \\
\hline $10 / 2$ & Fish Lake & West Fork Klickitat & Klickitat & 10 & $\mathrm{Bk}$ & 85 & started about $1 / 4 \mathrm{mi}$. below Fish Lake \\
\hline $10 / 2$ & Fish Lake & West Fork Klickitat & Klickitat & 10 & $\mathrm{Bk}$ & 127 & started about $1 / 4 \mathrm{mi}$. below Fish Lake \\
\hline $10 / 2$ & Fish Lake & West Fork Klickitat & Klickitat & 10 & $\mathrm{Bk}$ & 99 & started about $1 / 4$ mi. below Fish Lake \\
\hline $10 / 2$ & Fish Lake & West Fork Klickitat & Klickitat & 10 & $\mathrm{Bk}$ & 120 & started about $1 / 4$ mi. below Fish Lake \\
\hline $10 / 2$ & Fish Lake & West Fork Klickitat & Klickitat & 10 & $\mathrm{Bk}$ & 122 & started about $1 / 4$ mi. below Fish Lake \\
\hline $10 / 2$ & Fish Lake & West Fork Klickitat & Klickitat & 10 & $\mathrm{Bk}$ & 78 & started about $1 / 4$ mi. below Fish Lake \\
\hline $10 / 2$ & Fish Lake & West Fork Klickitat & Klickitat & 10 & $\mathrm{Bk}$ & 73 & started about $1 / 4$ mi. below Fish Lake \\
\hline $10 / 2$ & Fish Lake & West Fork Klickitat & Klickitat & 10 & $\mathrm{Bk}$ & 74 & started about $1 / 4 \mathrm{mi}$. below Fish Lake \\
\hline $10 / 2$ & Fish Lake & West Fork Klickitat & Klickitat & 10 & Bk & 67 & started about $1 / 4 \mathrm{mi}$. below Fish Lake \\
\hline $10 / 2$ & Fish Lake & West Fork Klickitat & Klickitat & 10 & $\mathrm{Bk}$ & 105 & started about $1 / 4$ mi. below Fish Lake \\
\hline $10 / 2$ & Fish Lake & West Fork Klickitat & Klickitat & 10 & $\mathrm{Bk}$ & 115 & started about 1/4 mi. below Fish Lake \\
\hline $10 / 2$ & Fish Lake & West Fork Klickitat & Klickitat & 10 & $\mathrm{Bk}$ & 90 & started about $1 / 4$ mi. below Fish Lake \\
\hline $10 / 2$ & Fish Lake & West Fork Klickitat & Klickitat & 10 & $\mathrm{Bk}$ & 75 & started about $1 / 4 \mathrm{mi}$. below Fish Lake \\
\hline $10 / 2$ & Fish Lake & West Fork Klickitat & Klickitat & 10 & $\mathrm{Bk}$ & 112 & started about $1 / 4 \mathrm{mi}$. below Fish Lake \\
\hline $10 / 2$ & Fish Lake & West Fork Klickitat & Klickitat & 10 & $\mathrm{Bk}$ & 147 & started about $1 / 4$ mi. below Fish Lake \\
\hline $10 / 2$ & Fish Lake & West Fork Klickitat & Klickitat & 10 & $\mathrm{Bk}$ & 174 & started about 1/4 mi. below Fish Lake \\
\hline $10 / 2$ & Fish Lake & West Fork Klickitat & Klickitat & 10 & $\mathrm{Bk}$ & 117 & started about $1 / 4$ mi. below Fish Lake \\
\hline $10 / 2$ & Fish Lake & West Fork Klickitat & Klickitat & 10 & $\mathrm{Bk}$ & 97 & started about $1 / 4$ mi. below Fish Lake \\
\hline $10 / 2$ & Fish Lake & West Fork Klickitat & Klickitat & 10 & $\mathrm{Bk}$ & 57 & started about $1 / 4 \mathrm{mi}$. below Fish Lake \\
\hline $10 / 2$ & Fish Lake & West Fork Klickitat & Klickitat & 10 & $\mathrm{Bk}$ & 111 & started about 1/4 mi. below Fish Lake \\
\hline $10 / 2$ & Fish Lake & West Fork Klickitat & Klickitat & 10 & $\mathrm{Bk}$ & 124 & started about $1 / 4$ mi. below Fish Lake \\
\hline $10 / 2$ & Fish Lake & West Fork Klickitat & Klickitat & 10 & $\mathrm{Bk}$ & 111 & started about 1/4 mi. below Fish Lake \\
\hline $10 / 2$ & Fish Lake & West Fork Klickitat & Klickitat & 10 & $\mathrm{Bk}$ & 143 & started about $1 / 4 \mathrm{mi}$. below Fish Lake \\
\hline $10 / 2$ & Fish Lake & West Fork Klickitat & Klickitat & 10 & $\mathrm{Bk}$ & 78 & started about 1/4 mi. below Fish Lake \\
\hline $10 / 2$ & Fish Lake & West Fork Klickitat & Klickitat & 10 & $\mathrm{Bk}$ & 62 & started about 1/4 mi. below Fish Lake \\
\hline $10 / 2$ & Fish Lake & West Fork Klickitat & Klickitat & 10 & $\mathrm{Bk}$ & 61 & started about $1 / 4$ mi. below Fish Lake \\
\hline $10 / 2$ & Fish Lake & West Fork Klickitat & Klickitat & 10 & $\mathrm{Bk}$ & 65 & started about $1 / 4$ mi. below Fish Lake \\
\hline $10 / 2$ & Fish Lake & West Fork Klickitat & Klickitat & 10 & $\mathrm{Bk}$ & 150 & started about $1 / 4$ mi. below Fish Lake \\
\hline $10 / 2$ & Cedar Creek & Klickitat & Klickitat & 9.8 & $\mathrm{Rb}$ & 51 & creek on east side of Klickitat River \\
\hline $10 / 2$ & Cedar Creek & Klickitat & Klickitat & 9.8 & $\mathrm{Rb}$ & 46 & creek on east side of Klickitat River \\
\hline $10 / 2$ & Cedar Creek & Klickitat & Klickitat & 9.8 & $\mathrm{Rb}$ & 44 & creek on east side of Klickitat River \\
\hline $10 / 2$ & Cedar Creek & Klickitat & Klickitat & 9.8 & $\mathrm{Rb}$ & 49 & creek on east side of Klickitat River \\
\hline $10 / 2$ & Cedar Creek & Klickitat & Klickitat & 9.8 & $\mathrm{Rb}$ & 79 & creek on east side of Klickitat River \\
\hline $10 / 2$ & Cedar Creek & Klickitat & Klickitat & 9.8 & $\mathrm{Rb}$ & 75 & creek on east side of Klickitat River \\
\hline $10 / 2$ & Cedar Creek & \begin{tabular}{|l} 
Klickitat \\
\end{tabular} & \begin{tabular}{|l} 
Klickitat \\
\end{tabular} & 9.8 & $\mathrm{Rb}$ & 51 & creek on east side of Klickitat River \\
\hline $10 / 2$ & Cedar Creek & \begin{tabular}{|l|} 
Klickitat \\
\end{tabular} & \begin{tabular}{|l|} 
Klickitat \\
\end{tabular} & 9.8 & $\mathrm{Rb}$ & 49 & creek on east side of Klickitat River \\
\hline $10 / 2$ & Cedar Creek & Klickitat & Klickitat & 9.8 & $\mathrm{Rb}$ & 51 & creek on east side of Klickitat River \\
\hline
\end{tabular}


Appendix C. Electroshock data from streams in the Klickitat and White Salmon river basins, 2001.

\begin{tabular}{|c|c|c|c|c|c|c|c|}
\hline $10 / 2$ & Cedar Creek & Klickitat & Klickitat & 9.8 & $\mathrm{Rb}$ & 45 & creek on east side of Klickitat River \\
\hline $10 / 2$ & Cedar Creek & Klickitat & Klickitat & 9.8 & $\mathrm{Rb}$ & 42 & creek on east side of Klickitat River \\
\hline $10 / 2$ & Cedar Creek & Klickitat & Klickitat & 9.8 & $\mathrm{Rb}$ & 46 & creek on east side of Klickitat River \\
\hline $10 / 2$ & Cedar Creek & Klickitat & Klickitat & 9.8 & $\mathrm{Rb}$ & 115 & creek on east side of Klickitat River \\
\hline $10 / 2$ & Cedar Creek & Klickitat & Klickitat & 9.8 & $\mathrm{Rb}$ & 98 & creek on east side of Klickitat River \\
\hline $10 / 2$ & Cedar Creek & Klickitat & Klickitat & 9.8 & $\mathrm{Rb}$ & 62 & creek on east side of Klickitat River \\
\hline $10 / 2$ & Cedar Creek & Klickitat & Klickitat & 9.8 & $\mathrm{Rb}$ & 56 & creek on east side of Klickitat River \\
\hline $10 / 2$ & Cedar Creek & Klickitat & Klickitat & 9.8 & $\mathrm{Rb}$ & 120 & creek on east side of Klickitat River \\
\hline $10 / 2$ & Cedar Creek & Klickitat & Klickitat & 9.8 & $\mathrm{Rb}$ & 90 & creek on east side of Klickitat River \\
\hline $10 / 2$ & Cedar Creek & Klickitat & Klickitat & 9.8 & $\mathrm{Rb}$ & 84 & creek on east side of Klickitat River \\
\hline $10 / 2$ & Cedar Creek & Klickitat & Klickitat & 9.8 & $\mathrm{Rb}$ & 122 & creek on east side of Klickitat River \\
\hline $10 / 2$ & Cedar Creek & Klickitat & Klickitat & 9.8 & $\mathrm{Rb}$ & 39 & creek on east side of Klickitat River \\
\hline $10 / 2$ & Cedar Creek & Klickitat & Klickitat & 9.8 & $\mathrm{Rb}$ & 73 & creek on east side of Klickitat River \\
\hline $10 / 2$ & Cedar Creek & Klickitat & Klickitat & 9.8 & $\mathrm{Rb}$ & 105 & creek on east side of Klickitat River \\
\hline $10 / 2$ & Cedar Creek & Klickitat & Klickitat & 9.8 & $\mathrm{Rb}$ & 36 & creek on east side of Klickitat River \\
\hline $10 / 2$ & Cedar Creek & Klickitat & Klickitat & 9.8 & $\mathrm{Rb}$ & 38 & creek on east side of Klickitat River \\
\hline $10 / 2$ & Cedar Creek & Klickitat & Klickitat & 9.8 & $\mathrm{Rb}$ & 45 & creek on east side of Klickitat River \\
\hline $10 / 2$ & Cedar Creek & Klickitat & Klickitat & 9.8 & $\mathrm{Rb}$ & 54 & creek on east side of Klickitat River \\
\hline $10 / 2$ & Cedar Creek & Klickitat & Klickitat & 9.8 & $\mathrm{Rb}$ & 78 & creek on east side of Klickitat River \\
\hline $10 / 2$ & Cedar Creek & Klickitat & Klickitat & 9.8 & $\mathrm{Rb}$ & 78 & creek on east side of Klickitat River \\
\hline $10 / 2$ & Cedar Creek & Klickitat & Klickitat & 9.8 & $\mathrm{Rb}$ & 68 & creek on east side of Klickitat River \\
\hline $10 / 2$ & Cedar Creek & Klickitat & Klickitat & 9.8 & $\mathrm{Rb}$ & 72 & creek on east side of Klickitat River \\
\hline $10 / 2$ & Cedar Creek & Klickitat & Klickitat & 9.8 & $\mathrm{Rb}$ & 78 & creek on east side of Klickitat River \\
\hline $10 / 2$ & Cedar Creek & Klickitat & Klickitat & 9.8 & $\mathrm{Rb}$ & 42 & creek on east side of Klickitat River \\
\hline $10 / 2$ & Cedar Creek & Klickitat & Klickitat & 9.8 & $\mathrm{Rb}$ & 106 & creek on east side of Klickitat River \\
\hline $10 / 2$ & Cedar Creek & Klickitat & Klickitat & 9.8 & $\mathrm{Rb}$ & 142 & creek on east side of Klickitat River \\
\hline $10 / 2$ & Cedar Creek & Klickitat & Klickitat & 9.8 & $\mathrm{Rb}$ & 74 & creek on east side of Klickitat River \\
\hline $10 / 2$ & Cedar Creek & Klickitat & Klickitat & 9.8 & $\mathrm{Rb}$ & 155 & creek on east side of Klickitat River \\
\hline $10 / 2$ & Cedar Creek & Klickitat & Klickitat & 9.8 & $\mathrm{Rb}$ & 131 & creek on east side of Klickitat River \\
\hline $10 / 2$ & Cedar Creek & Klickitat & Klickitat & 9.8 & $\mathrm{Rb}$ & 85 & creek on east side of Klickitat River \\
\hline $10 / 2$ & Cedar Creek & Klickitat & Klickitat & 9.8 & $\mathrm{Rb}$ & 80 & creek on east side of Klickitat River \\
\hline $10 / 2$ & Cedar Creek & Klickitat & Klickitat & 9.8 & $\mathrm{Rb}$ & 60 & creek on east side of Klickitat River \\
\hline $10 / 3$ & Unnamed \#1 & Two Lakes & Klickitat & 4.5 & Bk & 117 & NW of NW Section 19 \\
\hline $10 / 3$ & Unnamed \#1 & Two Lakes & Klickitat & 4.5 & Bk & 47 & NW of NW Section 19 \\
\hline $10 / 3$ & Unnamed \#1 & Two Lakes & Klickitat & 4.5 & $\mathrm{Bk}$ & 80 & NW of NW Section 19 \\
\hline $10 / 3$ & Unnamed \#1 & Two Lakes & \begin{tabular}{|l|} 
Klickitat \\
\end{tabular} & 4.5 & $\mathrm{Bk}$ & 75 & NW of NW Section 19 \\
\hline $10 / 3$ & Unnamed \#1 & Two Lakes & Klickitat & 4.5 & $\mathrm{Bk}$ & 82 & NW of NW Section 19 \\
\hline $10 / 3$ & Unnamed \#1 & Two Lakes & Klickitat & 4.5 & $\mathrm{Bk}$ & 108 & NW of NW Section 19 \\
\hline $10 / 3$ & Unnamed \#1 & Two Lakes & Klickitat & 4.5 & $\mathrm{Bk}$ & 103 & NW of NW Section 19 \\
\hline $10 / 3$ & Unnamed \#1 & Two Lakes & Klickitat & 4.5 & $\mathrm{Bk}$ & 138 & NW of NW Section 19 \\
\hline $10 / 3$ & Unnamed \#1 & Two Lakes & Klickitat & 4.5 & Bk & 75 & NW of NW Section 19 \\
\hline $10 / 3$ & Unnamed \#1 & Two Lakes & Klickitat & 4.5 & $\mathrm{Bk}$ & 119 & NW of NW Section 19 \\
\hline $10 / 3$ & Unnamed \#1 & Two Lakes & Klickitat & 4.5 & Bk & 90 & NW of NW Section 19 \\
\hline $10 / 3$ & Unnamed \#1 & Two Lakes & Klickitat & 4.5 & $\mathrm{Bk}$ & 115 & NW of NW Section 19 \\
\hline $10 / 3$ & Unnamed \#1 & Two Lakes & Klickitat & 4.5 & $\mathrm{Bk}$ & 126 & NW of NW Section 19 \\
\hline $10 / 3$ & Unnamed \#1 & Two Lakes & Klickitat & 4.5 & $\mathrm{Bk}$ & 150 & NW of NW Section 19 \\
\hline $10 / 3$ & Unnamed \#2 & Two Lakes & Klickitat & 4.5 & Bk & 91 & \\
\hline $10 / 3$ & Unnamed \#2 & Two Lakes & Klickitat & 4.5 & $\mathrm{Bk}$ & 138 & \\
\hline $10 / 10$ & Big Muddy & Klickitat & Klickitat & 4.5 & & & no fish, shocked at Road 255 bridge \\
\hline $10 / 10$ & Summit & Klickitat & Klickitat & 4.5 & $\mathrm{Rb}$ & 92 & \\
\hline $10 / 10$ & Summit & Klickitat & Klickitat & 4.5 & $\mathrm{Rb}$ & 46 & \\
\hline $10 / 10$ & Summit & Klickitat & Klickitat & 4.5 & $\mathrm{Rb}$ & 54 & \\
\hline $10 / 10$ & Summit & \begin{tabular}{|l} 
Klickitat \\
\end{tabular} & Klickitat & 4.5 & $\mathrm{Rb}$ & 47 & \\
\hline $10 / 10$ & Summit & Klickitat & Klickitat & 4.5 & $\mathrm{Rb}$ & 111 & \\
\hline $10 / 10$ & Summit & \begin{tabular}{|l|} 
Klickitat \\
\end{tabular} & \begin{tabular}{|l|} 
Klickitat \\
\end{tabular} & 4.5 & $\mathrm{Rb}$ & 46 & \\
\hline $10 / 10$ & Summit & Klickitat & \begin{tabular}{|l|} 
Klickitat \\
\end{tabular} & 4.5 & $\mathrm{Rb}$ & 105 & \\
\hline $10 / 10$ & Summit & Klickitat & Klickitat & 4.5 & $\mathrm{Rb}$ & 100 & \\
\hline $10 / 10$ & Summit & Klickitat & Klickitat & 4.5 & $\mathrm{Rb}$ & 81 & \\
\hline $10 / 10$ & Summit & Klickitat & Klickitat & 4.5 & $\mathrm{Rb}$ & 89 & \\
\hline $10 / 10$ & Summit & Klickitat & \begin{tabular}{|l|} 
Klickitat \\
\end{tabular} & 4.5 & $\mathrm{Rb}$ & 110 & \\
\hline $10 / 10$ & Summit & Klickitat & \begin{tabular}{|l|} 
Klickitat \\
\end{tabular} & 4.5 & $\mathrm{Rb}$ & 112 & \\
\hline $10 / 10$ & Summit & Klickitat & Klickitat & 4.5 & $\mathrm{Rb}$ & 44 & \\
\hline $10 / 10$ & Summit & \begin{tabular}{|l} 
Klickitat \\
\end{tabular} & Klickitat & 4.5 & $\mathrm{Rb}$ & 81 & \\
\hline $10 / 10$ & Summit & Klickitat & Klickitat & 4.5 & $\mathrm{Rb}$ & 125 & \\
\hline $10 / 10$ & Summit & Klickitat & Klickitat & 4.5 & $\mathrm{Rb}$ & 83 & \\
\hline $10 / 10$ & Summit & Klickitat & \begin{tabular}{|l|} 
Klickitat \\
\end{tabular} & 4.5 & $\mathrm{Rb}$ & 108 & \\
\hline $10 / 10$ & Summit & Klickitat & \begin{tabular}{|l|} 
Klickitat \\
\end{tabular} & 4.5 & $\mathrm{Rb}$ & 94 & \\
\hline $10 / 10$ & Summit & \begin{tabular}{|l|} 
Klickitat \\
\end{tabular} & \begin{tabular}{|l|} 
Klickitat \\
\end{tabular} & 4.5 & $\mathrm{Rb}$ & 86 & \\
\hline $10 / 10$ & Summit & Klickitat & Klickitat & 4.5 & Bk & 122 & \\
\hline
\end{tabular}


Appendix C. Electroshock data from streams in the Klickitat and White Salmon river basins, 2001.

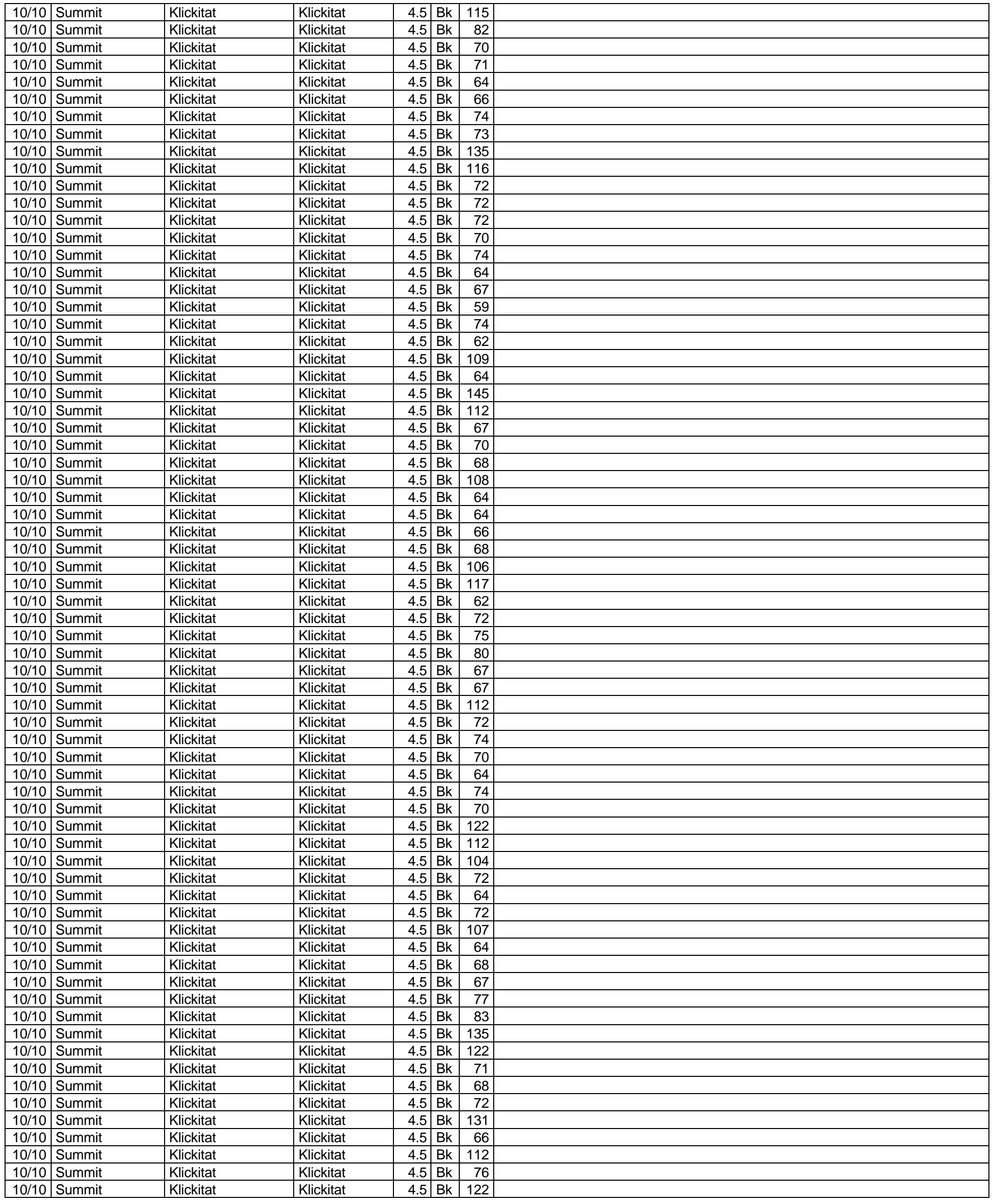


Appendix C. Electroshock data from streams in the Klickitat and White Salmon river basins, 2001.

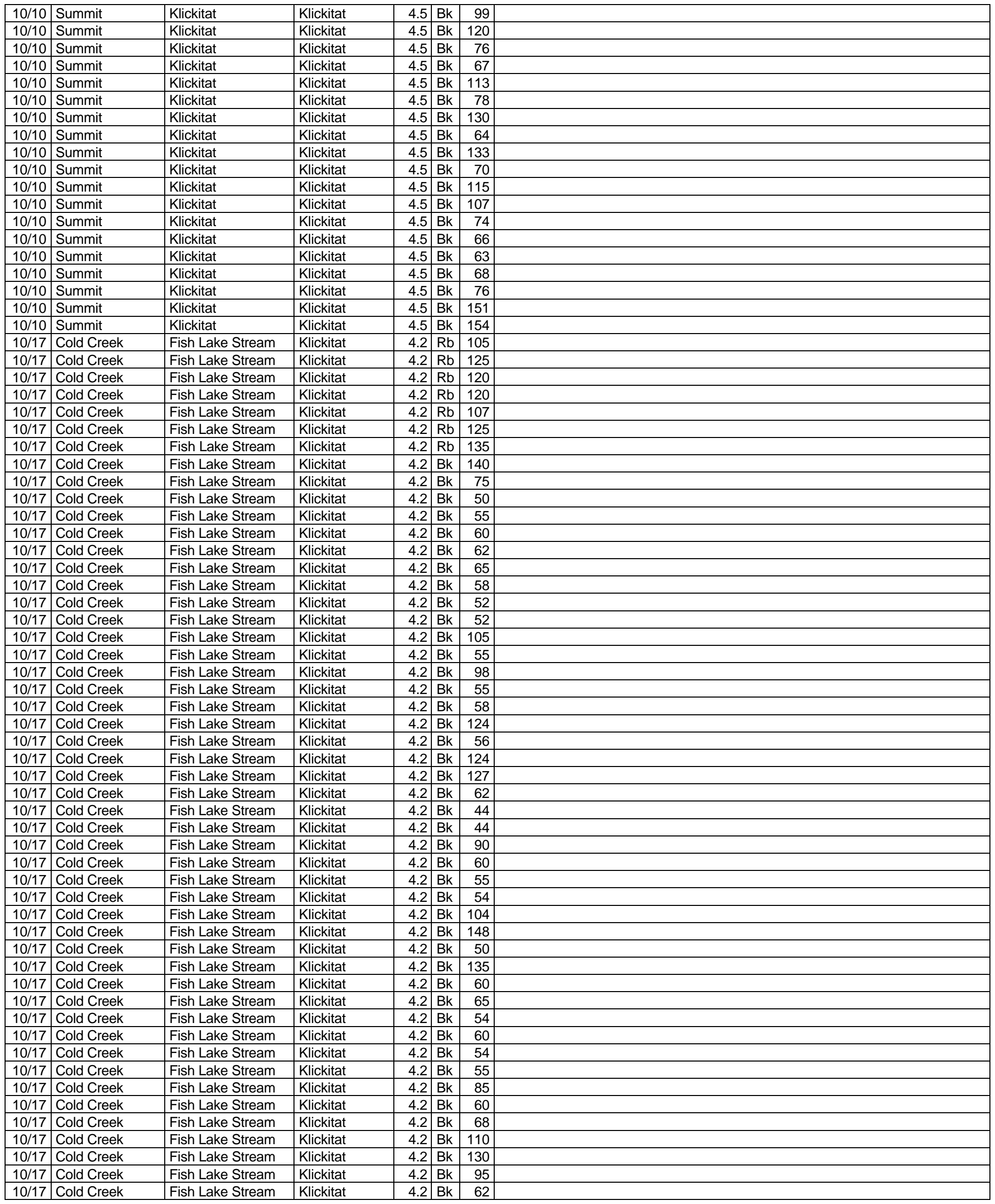


Appendix C. Electroshock data from streams in the Klickitat and White Salmon river basins, 2001.

\begin{tabular}{|c|c|c|c|c|c|c|c|}
\hline $10 / 17$ & Cold Creek & Fish Lake Stream & Klickitat & 4.2 & Bk & 63 & \\
\hline $10 / 17$ & Cold Creek & Fish Lake Stream & Klickitat & 4.2 & $\mathrm{Bk}$ & 148 & \\
\hline $10 / 17$ & Cold Creek & Fish Lake Stream & Klickitat & 4.2 & $\mathrm{Bk}$ & 138 & \\
\hline $10 / 17$ & Cold Creek & Fish Lake Stream & Klickitat & 4.2 & $\mathrm{Bk}$ & 133 & \\
\hline $10 / 17$ & Cold Creek & Fish Lake Stream & Klickitat & 4.2 & $\mathrm{Bk}$ & 105 & \\
\hline $10 / 17$ & Cold Creek & Fish Lake Stream & Klickitat & 4.2 & $\mathrm{Bk}$ & 155 & \\
\hline $10 / 17$ & Cold Creek & Fish Lake Stream & Klickitat & 4.2 & $\mathrm{Bk}$ & 158 & \\
\hline $10 / 17$ & Cold Creek & Fish Lake Stream & Klickitat & 4.2 & Bk & 155 & \\
\hline $10 / 17$ & Cold Creek & Fish Lake Stream & Klickitat & 4.2 & $\mathrm{Bk}$ & 156 & \\
\hline $10 / 17$ & Cold Creek & Fish Lake Stream & Klickitat & 4.2 & $\mathrm{Bk}$ & 182 & \\
\hline $10 / 29$ & East Prong & Little Klickitat & Klickitat & 7.2 & $\mathrm{Rb}$ & 91 & 4 sculpin and 43 dace; hwy 97 at Brooks Memorial Park \\
\hline $10 / 29$ & East Prong & Little Klickitat & Klickitat & 7.2 & $\mathrm{Rb}$ & 101 & Hwy 97 at Brooks Memorial Park \\
\hline $10 / 29$ & East Prong & Little Klickitat & Klickitat & 7.2 & $\mathrm{Rb}$ & 94 & Hwy 97 at Brooks Memorial Park \\
\hline $10 / 29$ & East Prong & Little Klickitat & Klickitat & 7.2 & $\mathrm{Rb}$ & 96 & Hwy 97 at Brooks Memorial Park \\
\hline $10 / 29$ & East Prong & Little Klickitat & Klickitat & 7.2 & $\mathrm{Rb}$ & 151 & Hwy 97 at Brooks Memorial Park \\
\hline $10 / 29$ & East Prong & Little Klickitat & Klickitat & 7.2 & $\mathrm{Rb}$ & 156 & Hwy 97 at Brooks Memorial Park \\
\hline $10 / 29$ & East Prong & Little Klickitat & Klickitat & 7.2 & $\mathrm{Rb}$ & 158 & Hwy 97 at Brooks Memorial Park \\
\hline $10 / 29$ & East Prong & Little Klickitat & Klickitat & 7.2 & $\mathrm{Rb}$ & 165 & Hwy 97 at Brooks Memorial Park \\
\hline $10 / 29$ & East Prong & Little Klickitat & Klickitat & 7.2 & $\mathrm{Rb}$ & 93 & Hwy 97 at Brooks Memorial Park \\
\hline $10 / 29$ & East Prong & Little Klickitat & Klickitat & 7.2 & $\mathrm{Rb}$ & 125 & Hwy 97 at Brooks Memorial Park \\
\hline $10 / 29$ & East Prong & Little Klickitat & Klickitat & 7.2 & $\mathrm{Rb}$ & 136 & Hwy 97 at Brooks Memorial Park \\
\hline $10 / 29$ & East Prong & Little Klickitat & Klickitat & 7.2 & $\mathrm{Rb}$ & 130 & Hwy 97 at Brooks Memorial Park \\
\hline $10 / 29$ & East Prong & Little Klickitat & Klickitat & 7.2 & $\mathrm{Rb}$ & 142 & Hwy 97 at Brooks Memorial Park \\
\hline $10 / 29$ & East Prong & Little Klickitat & Klickitat & 7.2 & $\mathrm{Rb}$ & 85 & Hwy 97 at Brooks Memorial Park \\
\hline $10 / 29$ & East Prong & Little Klickitat & Klickitat & 7.2 & $\mathrm{Rb}$ & 100 & Hwy 97 at Brooks Memorial Park \\
\hline $10 / 29$ & East Prong & Little Klickitat & Klickitat & 7.2 & $\mathrm{Rb}$ & 90 & Hwy 97 at Brooks Memorial Park \\
\hline $10 / 29$ & East Prong & Little Klickitat & Klickitat & 7.2 & $\mathrm{Rb}$ & 97 & Hwy 97 at Brooks Memorial Park \\
\hline $10 / 29$ & East Prong & Little Klickitat & Klickitat & 7.2 & $\mathrm{Rb}$ & 93 & Hwy 97 at Brooks Memorial Park \\
\hline $10 / 29$ & East Prong & Little Klickitat & Klickitat & 7.2 & $\mathrm{Rb}$ & 138 & Hwy 97 at Brooks Memorial Park \\
\hline $10 / 29$ & East Prong & Little Klickitat & Klickitat & 7.2 & $\mathrm{Rb}$ & 115 & Hwy 97 at Brooks Memorial Park \\
\hline $10 / 29$ & East Prong & Little Klickitat & Klickitat & 7.2 & $\mathrm{Rb}$ & 90 & Hwy 97 at Brooks Memorial Park \\
\hline $10 / 29$ & East Prong & Little Klickitat & Klickitat & 7.2 & $\mathrm{Rb}$ & 98 & Hwy 97 at Brooks Memorial Park \\
\hline $10 / 29$ & East Prong & Little Klickitat & Klickitat & 7.2 & $\mathrm{Rb}$ & 90 & Hwy 97 at Brooks Memorial Park \\
\hline $10 / 29$ & Butler & Little Klickitat & Klickitat & 7.2 & $\mathrm{Rb}$ & 185 & Lower Butler Creek site just west of Hwy $97 ; 4$ sculpin and 43 dace \\
\hline $10 / 29$ & Butler & Little Klickitat & Klickitat & 7.2 & $\mathrm{Rb}$ & 202 & Lower Butler Creek site just west of Hwy 97 \\
\hline $10 / 29$ & Butler & Little Klickitat & Klickitat & 7.2 & $\mathrm{Rb}$ & 119 & Lower Butler Creek site just west of Hwy 97 \\
\hline $10 / 29$ & Butler & Little Klickitat & Klickitat & 7.2 & $\mathrm{Rb}$ & 124 & Lower Butler Creek site just west of Hwy 97 \\
\hline $10 / 29$ & Butler & Little Klickitat & Klickitat & 7.2 & $\mathrm{Rb}$ & 94 & Lower Butler Creek site just west of Hwy 97 \\
\hline $10 / 29$ & Butler & Little Klickitat & Klickitat & 7.2 & $\mathrm{Rb}$ & 126 & Lower Butler Creek site just west of Hwy 97 \\
\hline $10 / 29$ & Butler & Little Klickitat & Klickitat & 7.2 & $\mathrm{Rb}$ & 101 & Lower Butler Creek site just west of Hwy 97 \\
\hline $10 / 29$ & Butler & Little Klickitat & Klickitat & 7.2 & $\mathrm{Rb}$ & 58 & Lower Butler Creek site just west of Hwy 97 \\
\hline $10 / 29$ & Butler & Little Klickitat & Klickitat & 7.2 & $\mathrm{Rb}$ & 178 & Lower Butler Creek site just west of Hwy 97 \\
\hline $10 / 29$ & Butler & Little Klickitat & Klickitat & 7.2 & $\mathrm{Rb}$ & 68 & Lower Butler Creek site just west of Hwy 97 \\
\hline $10 / 29$ & Butler & Little Klickitat & Klickitat & 7.2 & $\mathrm{Rb}$ & 106 & Lower Butler Creek site just west of Hwy 97 \\
\hline $10 / 29$ & Butler & Little Klickitat & Klickitat & 7.2 & $\mathrm{Rb}$ & 100 & Lower Butler Creek site just west of Hwy 97 \\
\hline $10 / 29$ & Butler & Little Klickitat & Klickitat & 7.2 & $\mathrm{Rb}$ & 56 & Lower Butler Creek site just west of Hwy 97 \\
\hline $10 / 29$ & Butler & Little Klickitat & Klickitat & 7.2 & $\mathrm{Rb}$ & 97 & Lower Butler Creek site just west of Hwy 97 \\
\hline $10 / 29$ & Butler & Little Klickitat & Klickitat & 7.2 & $\mathrm{Rb}$ & 72 & Lower Butler Creek site just west of Hwy 97 \\
\hline $10 / 29$ & Butler & Little Klickitat & Klickitat & 7.2 & $\mathrm{Rb}$ & 58 & Lower Butler Creek site just west of Hwy 97 \\
\hline $10 / 29$ & Butler & Little Klickitat & Klickitat & 7.2 & $\mathrm{Rb}$ & 57 & Lower Butler Creek site just west of Hwy 97 \\
\hline $10 / 29$ & Butler & Little Klickitat & Klickitat & 7.2 & $\mathrm{Rb}$ & 66 & Lower Butler Creek site just west of Hwy 97 \\
\hline $10 / 29$ & Butler & Little Klickitat & Klickitat & 7.2 & $\mathrm{Rb}$ & 108 & Lower Butler Creek site just west of Hwy 97 \\
\hline $10 / 29$ & Butler & Little Klickitat & Klickitat & 7.2 & $\mathrm{Rb}$ & 116 & Lower Butler Creek site just west of Hwy 97 \\
\hline $10 / 29$ & Butler & Little Klickitat & Klickitat & 7.2 & $\mathrm{Rb}$ & 98 & Lower Butler Creek site just west of Hwy 97 \\
\hline $10 / 31$ & Bowman & Little Klickitat & Klickitat & 6.7 & $\mathrm{Rb}$ & 155 & shocked at Lower Bowman Camp \\
\hline $10 / 31$ & Bowman & Little Klickitat & Klickitat & 6.7 & $\mathrm{Rb}$ & 98 & shocked at Lower Bowman Camp \\
\hline $10 / 31$ & Bowman & Little Klickitat & Klickitat & 6.7 & $\mathrm{Rb}$ & 96 & shocked at Lower Bowman Camp \\
\hline $10 / 31$ & Bowman & Little Klickitat & Klickitat & 6.7 & $\mathrm{Rb}$ & 116 & shocked at Lower Bowman Camp \\
\hline $10 / 31$ & Bowman & Little Klickitat & Klickitat & 6.7 & $\mathrm{Rb}$ & 107 & shocked at Lower Bowman Camp \\
\hline $10 / 31$ & Bowman & Little Klickitat & Klickitat & 6.7 & $\mathrm{Rb}$ & 98 & shocked at Lower Bowman Camp \\
\hline $10 / 31$ & Bowman & Little Klickitat & Klickitat & 6.7 & $\mathrm{Rb}$ & 88 & shocked at Lower Bowman Camp \\
\hline $10 / 31$ & Bowman & Little Klickitat & Klickitat & 6.7 & $\mathrm{Rb}$ & 62 & shocked at Lower Bowman Camp \\
\hline $10 / 31$ & Bowman & Little Klickitat & Klickitat & 6.7 & $\mathrm{Rb}$ & 46 & shocked at Lower Bowman Camp \\
\hline $10 / 31$ & Bowman & Little Klickitat & Klickitat & 6.7 & $\mathrm{Rb}$ & 53 & shocked at Lower Bowman Camp \\
\hline $10 / 31$ & Bowman & Little Klickitat & Klickitat & 6.7 & $\mathrm{Rb}$ & 42 & shocked at Lower Bowman Camp \\
\hline $10 / 31$ & Bowman & Little Klickitat & Klickitat & 6.7 & $\mathrm{Rb}$ & 48 & shocked at Lower Bowman Camp \\
\hline $10 / 31$ & Bowman & Little Klickitat & Klickitat & 6.7 & $\mathrm{Rb}$ & 164 & shocked at Lower Bowman Camp \\
\hline $10 / 31$ & Bowman & Little Klickitat & Klickitat & 6.7 & $\mathrm{Rb}$ & 100 & shocked at Lower Bowman Camp \\
\hline $10 / 31$ & Bowman & Little Klickitat & Klickitat & 6.7 & $\mathrm{Rb}$ & 58 & shocked at Lower Bowman Camp \\
\hline
\end{tabular}


Appendix C. Electroshock data from streams in the Klickitat and White Salmon river basins, 2001.

\begin{tabular}{|c|c|c|c|c|c|c|c|}
\hline $10 / 31$ & Bowman & Little Klickitat & Klickitat & 6.7 & $\mathrm{Rb}$ & 95 & shocked at Lower Bowman Camp \\
\hline $10 / 31$ & Bowman & Little Klickitat & Klickitat & 6.7 & $\mathrm{Rb}$ & 51 & shocked at Lower Bowman Camp \\
\hline $10 / 31$ & Bowman & Little Klickitat & Klickitat & 6.7 & $\mathrm{Rb}$ & 104 & shocked at Lower Bowman Camp \\
\hline $10 / 31$ & Bowman & Little Klickitat & Klickitat & 6.7 & $\mathrm{Rb}$ & 58 & shocked at Lower Bowman Camp \\
\hline $10 / 31$ & Bowman & Little Klickitat & Klickitat & 6.7 & $\mathrm{Rb}$ & 87 & shocked at Lower Bowman Camp \\
\hline $10 / 31$ & Bowman & Little Klickitat & Klickitat & 6.7 & $\mathrm{Rb}$ & 82 & shocked at Lower Bowman Camp \\
\hline $10 / 31$ & Bowman & Little Klickitat & Klickitat & 6.7 & $\mathrm{Rb}$ & 57 & shocked at Lower Bowman Camp \\
\hline $10 / 31$ & Bowman & Little Klickitat & Klickitat & 6.7 & $\mathrm{Rb}$ & 55 & shocked at Lower Bowman Camp \\
\hline $10 / 31$ & Bowman & Little Klickitat & Klickitat & 6.7 & $\mathrm{Rb}$ & 53 & shocked at Lower Bowman Camp \\
\hline $10 / 31$ & Bowman & Little Klickitat & Klickitat & 6.7 & $\mathrm{Rb}$ & 150 & shocked at Lower Bowman Camp \\
\hline $10 / 31$ & Bowman & Little Klickitat & Klickitat & 6.7 & $\mathrm{Rb}$ & 98 & shocked at Lower Bowman Camp \\
\hline $10 / 31$ & Bowman & Little Klickitat & Klickitat & 6.7 & $\mathrm{Rb}$ & 98 & shocked at Lower Bowman Camp \\
\hline $10 / 31$ & Bowman & Little Klickitat & Klickitat & 6.7 & $\mathrm{Rb}$ & 103 & shocked at Lower Bowman Camp \\
\hline $10 / 31$ & Bowman & Little Klickitat & Klickitat & 6.7 & $\mathrm{Rb}$ & 99 & shocked at Lower Bowman Camp \\
\hline $10 / 31$ & Bowman & Little Klickitat & Klickitat & 6.7 & $\mathrm{Rb}$ & 105 & shocked at Lower Bowman Camp \\
\hline $10 / 31$ & Bowman & Little Klickitat & Klickitat & 6.7 & $\mathrm{Rb}$ & 91 & shocked at Lower Bowman Camp \\
\hline $10 / 31$ & Bowman & Little Klickitat & Klickitat & 6.7 & $\mathrm{Rb}$ & 83 & shocked at Lower Bowman Camp \\
\hline $10 / 31$ & Bowman & Little Klickitat & Klickitat & 6.7 & $\mathrm{Rb}$ & 45 & shocked at Lower Bowman Camp \\
\hline $10 / 31$ & Bowman & Little Klickitat & Klickitat & 6.7 & $\mathrm{Rb}$ & 48 & shocked at Lower Bowman Camp \\
\hline $10 / 31$ & Bowman & Little Klickitat & Klickitat & 6.7 & $\mathrm{Rb}$ & 44 & shocked at Lower Bowman Camp \\
\hline $10 / 31$ & Bowman & \begin{tabular}{|l} 
Little Klickitat \\
\end{tabular} & Klickitat & 6.7 & $\mathrm{Rb}$ & 113 & shocked at Lower Bowman Camp \\
\hline $10 / 31$ & Bowman & Little Klickitat & Klickitat & 6.7 & $\mathrm{Rb}$ & 73 & shocked at Lower Bowman Camp \\
\hline $10 / 31$ & Bowman & Little Klickitat & Klickitat & 6.7 & $\mathrm{Rb}$ & 126 & shocked at Lower Bowman Camp \\
\hline $10 / 31$ & Bowman & Little Klickitat & Klickitat & 6.7 & $\mathrm{Rb}$ & 87 & shocked at Lower Bowman Camp \\
\hline $10 / 31$ & Bowman & Little Klickitat & Klickitat & 6.7 & $\mathrm{Rb}$ & 58 & shocked at Lower Bowman Camp \\
\hline $10 / 31$ & Bowman & Little Klickitat & Klickitat & 6.7 & $\mathrm{Rb}$ & 98 & shocked at Lower Bowman Camp \\
\hline $10 / 31$ & Bowman & Little Klickitat & Klickitat & 6.7 & $\mathrm{Rb}$ & 73 & shocked at Lower Bowman Camp \\
\hline $10 / 31$ & Bowman & Little Klickitat & Klickitat & 6.7 & $\mathrm{Rb}$ & 85 & shocked at Lower Bowman Camp \\
\hline $10 / 31$ & Bowman & Little Klickitat & Klickitat & 6.7 & $\mathrm{Rb}$ & 44 & shocked at Lower Bowman Camp \\
\hline $10 / 31$ & Bowman & Little Klickitat & Klickitat & 6.7 & $\mathrm{Rb}$ & 96 & shocked at Lower Bowman Camp \\
\hline $10 / 31$ & Bowman & Little Klickitat & Klickitat & 6.7 & $\mathrm{Rb}$ & 84 & shocked at Lower Bowman Camp \\
\hline $10 / 31$ & Bowman & Little Klickitat & Klickitat & 6.7 & $\mathrm{Rb}$ & 39 & shocked at Lower Bowman Camp \\
\hline $10 / 31$ & Bowman & \begin{tabular}{|l} 
Little Klickitat \\
\end{tabular} & Klickitat & 6.7 & $\mathrm{Rb}$ & 100 & shocked at Lower Bowman Camp \\
\hline $10 / 31$ & Bowman & Little Klickitat & Klickitat & 6.7 & $\mathrm{Rb}$ & 52 & shocked at Lower Bowman Camp \\
\hline $10 / 31$ & Bowman & Little Klickitat & Klickitat & 6.7 & $\mathrm{Rb}$ & 54 & shocked at Lower Bowman Camp \\
\hline $10 / 31$ & Bowman & Little Klickitat & Klickitat & 6.7 & $\mathrm{Rb}$ & 54 & shocked at Lower Bowman Camp \\
\hline $10 / 31$ & Bowman & Little Klickitat & Klickitat & 6.7 & $\mathrm{Rb}$ & 52 & shocked at Lower Bowman Camp \\
\hline $10 / 31$ & Bowman & Little Klickitat & Klickitat & 6.7 & $\mathrm{Rb}$ & 115 & shocked at Lower Bowman Camp \\
\hline $10 / 31$ & Bowman & \begin{tabular}{|l} 
Little Klickitat \\
\end{tabular} & Klickitat & 6.7 & $\mathrm{Rb}$ & 118 & shocked at Lower Bowman Camp \\
\hline $10 / 31$ & Bowman & Little Klickitat & Klickitat & 6.7 & $\mathrm{Rb}$ & 75 & shocked at Lower Bowman Camp \\
\hline $10 / 31$ & Bowman & Little Klickitat & Klickitat & 6.7 & $\mathrm{Rb}$ & 98 & shocked at Lower Bowman Camp \\
\hline $10 / 31$ & Bowman & Little Klickitat & Klickitat & 6.7 & $\mathrm{Rb}$ & 94 & shocked at Lower Bowman Camp \\
\hline $10 / 31$ & Bowman & Little Klickitat & Klickitat & 6.7 & $\mathrm{Rb}$ & 45 & shocked at Lower Bowman Camp \\
\hline $10 / 31$ & Bowman & Little Klickitat & Klickitat & 6.7 & $\mathrm{Rb}$ & 102 & shocked at Lower Bowman Camp \\
\hline $10 / 31$ & Bowman & Little Klickitat & Klickitat & 6.7 & $\mathrm{Rb}$ & 57 & shocked at Lower Bowman Camp \\
\hline $10 / 31$ & Bowman & Little Klickitat & Klickitat & 6.7 & $\mathrm{Rb}$ & 52 & shocked at Lower Bowman Camp \\
\hline $10 / 31$ & Bowman & Little Klickitat & Klickitat & 6.7 & $\mathrm{Rb}$ & 55 & shocked at Lower Bowman Camp \\
\hline $10 / 31$ & Bowman & Little Klickitat & Klickitat & 6.7 & $\mathrm{Rb}$ & 52 & shocked at Lower Bowman Camp \\
\hline $10 / 31$ & Bowman & Little Klickitat & Klickitat & 6.7 & $\mathrm{Rb}$ & 55 & shocked at Lower Bowman Camp \\
\hline $10 / 31$ & Bowman & Little Klickitat & Klickitat & 6.7 & $\mathrm{Rb}$ & 152 & shocked at Lower Bowman Camp \\
\hline $10 / 31$ & Bowman & Little Klickitat & Klickitat & 6.7 & $\mathrm{Rb}$ & 81 & shocked at Lower Bowman Camp \\
\hline $10 / 31$ & Bowman & Little Klickitat & Klickitat & 6.7 & $\mathrm{Rb}$ & 110 & shocked at Lower Bowman Camp \\
\hline $10 / 31$ & Bowman & Little Klickitat & Klickitat & 6.7 & $\mathrm{Rb}$ & 93 & shocked at Lower Bowman Camp \\
\hline $10 / 31$ & Bowman & Little Klickitat & Klickitat & 6.7 & $\mathrm{Rb}$ & 94 & shocked at Lower Bowman Camp \\
\hline $10 / 31$ & Bowman & Little Klickitat & Klickitat & 6.7 & $\mathrm{Rb}$ & 93 & shocked at Lower Bowman Camp \\
\hline $10 / 31$ & Bowman & Little Klickitat & Klickitat & 6.7 & $\mathrm{Rb}$ & 103 & shocked at Lower Bowman Camp \\
\hline $10 / 31$ & Bowman & Little Klickitat & Klickitat & 6.7 & $\mathrm{Rb}$ & 107 & shocked at Lower Bowman Camp \\
\hline $10 / 31$ & Bowman & Little Klickitat & Klickitat & 6.7 & $\mathrm{Rb}$ & 82 & shocked at Lower Bowman Camp \\
\hline $10 / 31$ & Bowman & Little Klickitat & Klickitat & 6.7 & $\mathrm{Rb}$ & 53 & shocked at Lower Bowman Camp \\
\hline $10 / 31$ & Bowman & Little Klickitat & Klickitat & 6.7 & $\mathrm{Rb}$ & 86 & shocked at Lower Bowman Camp \\
\hline $10 / 31$ & Bowman & Little Klickitat & Klickitat & 6.7 & $\mathrm{Rb}$ & 118 & shocked at Lower Bowman Camp \\
\hline $10 / 31$ & Bowman & Little Klickitat & Klickitat & 6.7 & $\mathrm{Rb}$ & 58 & shocked at Lower Bowman Camp \\
\hline $10 / 31$ & Bowman & Little Klickitat & Klickitat & 6.7 & $\mathrm{Rb}$ & 54 & shocked at Lower Bowman Camp \\
\hline $10 / 31$ & Bowman & Little Klickitat & Klickitat & 6.7 & $\mathrm{Rb}$ & 59 & shocked at Lower Bowman Camp \\
\hline $10 / 31$ & Bowman & Little Klickitat & Klickitat & 6.7 & $\mathrm{Rb}$ & 93 & shocked at Lower Bowman Camp \\
\hline $10 / 31$ & Bowman & \begin{tabular}{|l|} 
Little Klickitat \\
\end{tabular} & Klickitat & 6.7 & $\mathrm{Rb}$ & 58 & shocked at Lower Bowman Camp \\
\hline $10 / 31$ & Bowman & \begin{tabular}{|l} 
Little Klickitat \\
\end{tabular} & Klickitat & 6.7 & $\mathrm{Rb}$ & 53 & shocked at Lower Bowman Camp \\
\hline $10 / 31$ & Bowman & Little Klickitat & Klickitat & 6.7 & $\mathrm{Rb}$ & 53 & shocked at Lower Bowman Camp \\
\hline $10 / 31$ & Bowman & Little Klickitat & Klickitat & 7.5 & $\mathrm{Rb}$ & 92 & shocked at Upper Bowman Camp \\
\hline
\end{tabular}


Appendix C. Electroshock data from streams in the Klickitat and White Salmon river basins, 2001.

\begin{tabular}{|c|c|c|c|c|c|c|c|}
\hline $10 / 31$ & Bowman & Little Klickitat & Klickitat & 7.5 & $\mathrm{Rb}$ & 98 & shocked at Upper Bowman Camp \\
\hline $10 / 31$ & Bowman & Little Klickitat & Klickitat & 7.5 & $\mathrm{Rb}$ & 106 & shocked at Upper Bowman Camp \\
\hline $10 / 31$ & Bowman & Little Klickitat & Klickitat & 7.5 & $\mathrm{Rb}$ & 82 & shocked at Upper Bowman Camp \\
\hline $10 / 31$ & Bowman & Little Klickitat & Klickitat & 7.5 & $\mathrm{Rb}$ & 112 & shocked at Upper Bowman Camp \\
\hline $10 / 31$ & Bowman & Little Klickitat & Klickitat & 7.5 & $\mathrm{Rb}$ & 84 & shocked at Upper Bowman Camp \\
\hline $10 / 31$ & Bowman & Little Klickitat & Klickitat & 7.5 & $\mathrm{Rb}$ & 83 & shocked at Upper Bowman Camp \\
\hline $10 / 31$ & Bowman & Little Klickitat & Klickitat & 7.5 & $\mathrm{Rb}$ & 74 & shocked at Upper Bowman Camp \\
\hline $10 / 31$ & Bowman & Little Klickitat & Klickitat & 7.5 & $\mathrm{Rb}$ & 92 & shocked at Upper Bowman Camp \\
\hline $10 / 31$ & Bowman & Little Klickitat & Klickitat & 7.5 & $\mathrm{Rb}$ & 102 & shocked at Upper Bowman Camp \\
\hline $10 / 31$ & Bowman & Little Klickitat & Klickitat & 7.5 & $\mathrm{Rb}$ & 58 & shocked at Upper Bowman Camp \\
\hline $10 / 31$ & Bowman & Little Klickitat & Klickitat & 7.5 & $\mathrm{Rb}$ & 84 & shocked at Upper Bowman Camp \\
\hline $10 / 31$ & Bowman & Little Klickitat & Klickitat & 7.5 & $\mathrm{Rb}$ & 43 & shocked at Upper Bowman Camp \\
\hline $10 / 31$ & Bowman & Little Klickitat & Klickitat & 7.5 & $\mathrm{Rb}$ & 42 & shocked at Upper Bowman Camp \\
\hline $10 / 31$ & Bowman & Little Klickitat & Klickitat & 7.5 & $\mathrm{Rb}$ & 45 & shocked at Upper Bowman Camp \\
\hline $10 / 31$ & Bowman & Little Klickitat & Klickitat & 7.5 & $\mathrm{Rb}$ & 123 & shocked at Upper Bowman Camp \\
\hline $10 / 31$ & Bowman & Little Klickitat & Klickitat & 7.5 & $\mathrm{Rb}$ & 58 & shocked at Upper Bowman Camp \\
\hline $10 / 31$ & Bowman & Little Klickitat & Klickitat & 7.5 & $\mathrm{Rb}$ & 100 & shocked at Upper Bowman Camp \\
\hline $10 / 31$ & Bowman & Little Klickitat & Klickitat & 7.5 & $\mathrm{Rb}$ & 52 & shocked at Upper Bowman Camp \\
\hline $10 / 31$ & Bowman & Little Klickitat & Klickitat & 7.5 & $\mathrm{Rb}$ & 65 & shocked at Upper Bowman Camp \\
\hline $10 / 31$ & Bowman & Little Klickitat & Klickitat & 7.5 & $\mathrm{Rb}$ & 48 & shocked at Upper Bowman Camp \\
\hline $10 / 31$ & Bowman & Little Klickitat & Klickitat & 7.5 & $\mathrm{Rb}$ & 48 & shocked at Upper Bowman Camp \\
\hline $10 / 31$ & Bowman & Little Klickitat & Klickitat & 7.5 & $\mathrm{Rb}$ & 46 & shocked at Upper Bowman Camp \\
\hline $10 / 31$ & Bowman & Little Klickitat & Klickitat & 7.5 & $\mathrm{Rb}$ & 64 & shocked at Upper Bowman Camp \\
\hline $10 / 31$ & Bowman & Little Klickitat & Klickitat & 7.5 & $\mathrm{Rb}$ & 56 & shocked at Upper Bowman Camp \\
\hline $10 / 31$ & Bowman & Little Klickitat & Klickitat & 7.5 & $\mathrm{Rb}$ & 48 & shocked at Upper Bowman Camp \\
\hline $10 / 31$ & Bowman & Little Klickitat & Klickitat & 7.5 & $\mathrm{Rb}$ & 53 & shocked at Upper Bowman Camp \\
\hline $10 / 31$ & Bowman & Little Klickitat & Klickitat & 7.5 & $\mathrm{Rb}$ & 46 & shocked at Upper Bowman Camp \\
\hline $10 / 31$ & Bowman & \begin{tabular}{|l} 
Little Klickitat \\
\end{tabular} & Klickitat & 7.5 & $\mathrm{Rb}$ & 53 & shocked at Upper Bowman Camp \\
\hline $10 / 31$ & Bowman & Little Klickitat & Klickitat & 7.5 & $\mathrm{Rb}$ & 99 & shocked at Upper Bowman Camp \\
\hline $10 / 31$ & Bowman & Little Klickitat & Klickitat & 7.5 & $\mathrm{Rb}$ & 86 & shocked at Upper Bowman Camp \\
\hline $10 / 31$ & Bowman & Little Klickitat & Klickitat & 7.5 & $\mathrm{Rb}$ & 93 & shocked at Upper Bowman Camp \\
\hline $10 / 31$ & Bowman & Little Klickitat & Klickitat & 7.5 & $\mathrm{Rb}$ & 106 & shocked at Upper Bowman Camp \\
\hline $10 / 31$ & Bowman & \begin{tabular}{|l} 
Little Klickitat \\
\end{tabular} & Klickitat & 7.5 & $\mathrm{Rb}$ & 80 & shocked at Upper Bowman Camp \\
\hline $10 / 31$ & Bowman & Little Klickitat & Klickitat & 7.5 & $\mathrm{Rb}$ & 95 & shocked at Upper Bowman Camp \\
\hline $10 / 31$ & Bowman & Little Klickitat & Klickitat & 7.5 & $\mathrm{Rb}$ & 92 & shocked at Upper Bowman Camp \\
\hline $10 / 31$ & Bowman & Little Klickitat & Klickitat & 7.5 & $\mathrm{Rb}$ & 93 & shocked at Upper Bowman Camp \\
\hline $10 / 31$ & Bowman & Little Klickitat & Klickitat & 7.5 & $\mathrm{Rb}$ & 85 & shocked at Upper Bowman Camp \\
\hline $10 / 31$ & Bowman & Little Klickitat & Klickitat & 7.5 & $\mathrm{Rb}$ & 147 & shocked at Upper Bowman Camp \\
\hline $10 / 31$ & Bowman & \begin{tabular}{|l} 
Little Klickitat \\
\end{tabular} & Klickitat & 7.5 & $\mathrm{Rb}$ & 143 & shocked at Upper Bowman Camp \\
\hline $10 / 31$ & Bowman & Little Klickitat & Klickitat & 7.5 & $\mathrm{Rb}$ & 94 & shocked at Upper Bowman Camp \\
\hline $10 / 31$ & Bowman & Little Klickitat & Klickitat & 7.5 & $\mathrm{Rb}$ & 59 & shocked at Upper Bowman Camp \\
\hline $10 / 31$ & Bowman & Little Klickitat & Klickitat & 7.5 & $\mathrm{Rb}$ & 152 & shocked at Upper Bowman Camp \\
\hline $10 / 31$ & Bowman & Little Klickitat & Klickitat & 7.5 & $\mathrm{Rb}$ & 93 & shocked at Upper Bowman Camp \\
\hline $10 / 31$ & Bowman & Little Klickitat & Klickitat & 7.5 & $\mathrm{Rb}$ & 66 & shocked at Upper Bowman Camp \\
\hline $10 / 31$ & Bowman & Little Klickitat & Klickitat & 7.5 & $\mathrm{Rb}$ & 135 & shocked at Upper Bowman Camp \\
\hline $10 / 31$ & Bowman & Little Klickitat & Klickitat & 7.5 & $\mathrm{Rb}$ & 137 & shocked at Upper Bowman Camp \\
\hline $10 / 31$ & Bowman & Little Klickitat & Klickitat & 7.5 & $\mathrm{Rb}$ & 105 & shocked at Upper Bowman Camp \\
\hline $10 / 31$ & Bowman & Little Klickitat & Klickitat & 7.5 & $\mathrm{Rb}$ & 85 & shocked at Upper Bowman Camp \\
\hline $10 / 31$ & Bowman & Little Klickitat & Klickitat & 7.5 & $\mathrm{Rb}$ & 81 & shocked at Upper Bowman Camp \\
\hline $10 / 31$ & Bowman & Little Klickitat & Klickitat & 7.5 & $\mathrm{Rb}$ & 103 & shocked at Upper Bowman Camp \\
\hline $10 / 31$ & Bowman & Little Klickitat & Klickitat & 7.5 & $\mathrm{Rb}$ & 75 & shocked at Upper Bowman Camp \\
\hline $10 / 31$ & Bowman & Little Klickitat & Klickitat & 7.5 & $\mathrm{Rb}$ & 93 & shocked at Upper Bowman Camp \\
\hline $10 / 31$ & Bowman & Little Klickitat & Klickitat & 7.5 & $\mathrm{Rb}$ & 113 & shocked at Upper Bowman Camp \\
\hline $10 / 31$ & Bowman & Little Klickitat & Klickitat & 7.5 & $\mathrm{Rb}$ & 92 & shocked at Upper Bowman Camp \\
\hline $10 / 31$ & Bowman & Little Klickitat & Klickitat & 7.5 & $\mathrm{Rb}$ & 87 & shocked at Upper Bowman Camp \\
\hline $10 / 31$ & Bowman & Little Klickitat & Klickitat & 7.5 & $\mathrm{Rb}$ & 98 & shocked at Upper Bowman Camp \\
\hline $10 / 31$ & Bowman & Little Klickitat & Klickitat & 7.5 & $\mathrm{Rb}$ & 106 & shocked at Upper Bowman Camp \\
\hline $10 / 31$ & Bowman & Little Klickitat & Klickitat & 7.5 & $\mathrm{Rb}$ & 77 & shocked at Upper Bowman Camp \\
\hline $10 / 31$ & Bowman & Little Klickitat & Klickitat & 7.5 & $\mathrm{Rb}$ & 68 & shocked at Upper Bowman Camp \\
\hline $10 / 31$ & Bowman & Little Klickitat & Klickitat & 7.5 & $\mathrm{Rb}$ & 81 & shocked at Upper Bowman Camp \\
\hline $10 / 31$ & Bowman & \begin{tabular}{|l} 
Little Klickitat \\
\end{tabular} & Klickitat & 7.5 & $\mathrm{Rb}$ & 67 & shocked at Upper Bowman Camp \\
\hline $10 / 31$ & Bowman & Little Klickitat & Klickitat & 7.5 & $\mathrm{Rb}$ & 54 & shocked at Upper Bowman Camp \\
\hline $10 / 31$ & Bowman & Little Klickitat & Klickitat & 7.5 & $\mathrm{Rb}$ & 80 & shocked at Upper Bowman Camp \\
\hline $10 / 31$ & Bowman & Little Klickitat & Klickitat & 7.5 & $\mathrm{Rb}$ & 50 & shocked at Upper Bowman Camp \\
\hline $10 / 31$ & Bowman & Little Klickitat & Klickitat & 7.5 & $\mathrm{Rb}$ & 55 & shocked at Upper Bowman Camp \\
\hline $10 / 31$ & Mill & \begin{tabular}{|l|} 
Little Klickitat \\
\end{tabular} & Klickitat & 7.2 & $\mathrm{Rb}$ & 98 & west fork of Mill Creek \\
\hline $10 / 31$ & Mill & \begin{tabular}{|l} 
Little Klickitat \\
\end{tabular} & Klickitat & 7.2 & $\mathrm{Rb}$ & 97 & west fork of Mill Creek \\
\hline $10 / 31$ & Mill & Little Klickitat & Klickitat & 7.2 & $\mathrm{Rb}$ & 41 & west fork of Mill Creek \\
\hline $10 / 31$ & Mill & Little Klickitat & Klickitat & 7.2 & $\mathrm{Rb}$ & 49 & west fork of Mill Creek \\
\hline
\end{tabular}


Appendix C. Electroshock data from streams in the Klickitat and White Salmon river basins, 2001.

\begin{tabular}{|c|c|c|c|c|c|c|c|}
\hline $10 / 31$ & Mill & Little Klickitat & Klickitat & 7.2 & $\mathrm{Rb}$ & 52 & west fork of Mill Creek \\
\hline $10 / 31$ & Mill & Little Klickitat & Klickitat & 7.2 & $\mathrm{Rb}$ & 52 & west fork of Mill Creek \\
\hline $10 / 31$ & Mill & Little Klickitat & Klickitat & 7.2 & $\mathrm{Rb}$ & 161 & west fork of Mill Creek \\
\hline $10 / 31$ & Mill & Little Klickitat & Klickitat & 7.2 & $\mathrm{Rb}$ & 122 & west fork of Mill Creek \\
\hline $10 / 31$ & Mill & Little Klickitat & Klickitat & 7.2 & $\mathrm{Rb}$ & 77 & west fork of Mill Creek \\
\hline $10 / 31$ & \begin{tabular}{|l|l|} 
Mill \\
\end{tabular} & Little Klickitat & Klickitat & 7.2 & $\mathrm{Rb}$ & 95 & west fork of Mill Creek \\
\hline $10 / 31$ & \begin{tabular}{|l|l|} 
Mill \\
\end{tabular} & Little Klickitat & Klickitat & 7.2 & $\mathrm{Rb}$ & 58 & west fork of Mill Creek \\
\hline $10 / 31$ & \begin{tabular}{|l|l|} 
Mill \\
\end{tabular} & \begin{tabular}{|l} 
Little Klickitat \\
\end{tabular} & Klickitat & 7.2 & $\mathrm{Rb}$ & 53 & west fork of Mill Creek \\
\hline $10 / 31$ & Mill & Little Klickitat & Klickitat & 7.2 & $\mathrm{Rb}$ & 92 & west fork of Mill Creek \\
\hline $10 / 31$ & Mill & Little Klickitat & Klickitat & 7.2 & $\mathrm{Rb}$ & 63 & west fork of Mill Creek \\
\hline $10 / 31$ & Mill & Little Klickitat & Klickitat & 7.2 & $\mathrm{Rb}$ & 56 & west fork of Mill Creek \\
\hline $10 / 31$ & Mill & Little Klickitat & Klickitat & 7.2 & $\mathrm{Rb}$ & 48 & west fork of Mill Creek \\
\hline $10 / 31$ & Mill & Little Klickitat & Klickitat & 7.2 & $\mathrm{Rb}$ & 53 & west fork of Mill Creek \\
\hline $10 / 31$ & Mill & Little Klickitat & Klickitat & 7.2 & $\mathrm{Rb}$ & 50 & west fork of Mill Creek \\
\hline $10 / 31$ & Mill & Little Klickitat & Klickitat & 7.2 & $\mathrm{Rb}$ & 54 & west fork of Mill Creek \\
\hline $10 / 31$ & Mill & Little Klickitat & Klickitat & 7.2 & $\mathrm{Rb}$ & 54 & west fork of Mill Creek \\
\hline $10 / 31$ & Mill & Little Klickitat & Klickitat & 7.2 & $\mathrm{Rb}$ & 105 & west fork of Mill Creek \\
\hline $10 / 31$ & Mill & Little Klickitat & Klickitat & 7.2 & $\mathrm{Rb}$ & 132 & west fork of Mill Creek \\
\hline $10 / 31$ & Mill & Little Klickitat & Klickitat & 7.2 & $\mathrm{Rb}$ & 93 & west fork of Mill Creek \\
\hline $10 / 31$ & Mill & Little Klickitat & Klickitat & 7.2 & $\mathrm{Rb}$ & 53 & west fork of Mill Creek \\
\hline $10 / 31$ & \begin{tabular}{|l} 
Mill \\
\end{tabular} & Little Klickitat & Klickitat & 7.2 & $\mathrm{Rb}$ & 52 & west fork of Mill Creek \\
\hline $10 / 31$ & Mill & Little Klickitat & Klickitat & 7.2 & $\mathrm{Rb}$ & 51 & west fork of Mill Creek \\
\hline $10 / 31$ & Mill & Little Klickitat & Klickitat & 7.2 & $\mathrm{Rb}$ & 57 & west fork of Mill Creek \\
\hline $10 / 31$ & Mill & Little Klickitat & Klickitat & 7.2 & $\mathrm{Rb}$ & 61 & west fork of Mill Creek \\
\hline $10 / 31$ & Mill & Little Klickitat & Klickitat & 7.2 & $\mathrm{Rb}$ & 56 & west fork of Mill Creek \\
\hline $8 / 7$ & Huckleberry & Klickitat & Klickitat & 12.2 & & & no fish, site approx. $3 \mathrm{mi}$. above confluence \\
\hline $8 / 20$ & Huckleberry & Klickitat & Klickitat & 7.8 & & & no fish \\
\hline $8 / 20$ & Unnamed \#2 & Klickitat & Klickitat & 7.2 & & & no fish, trib. \#2 on north side of Klickitat River \\
\hline $8 / 20$ & Unnamed \#3 & Klickitat & Klickitat & 11.1 & $\mathrm{Rb}$ & 160 & trib. \#3 on north side of Klickitat River \\
\hline $8 / 20$ & Unnamed \#3 & Klickitat & Klickitat & 11.1 & $\mathrm{Rb}$ & 138 & trib. \#3 on north side of Klickitat River \\
\hline $8 / 20$ & Unnamed \#3 & Klickitat & Klickitat & 11.1 & $\mathrm{Rb}$ & 119 & trib. \#3 on north side of Klickitat River \\
\hline $8 / 20$ & Unnamed \#3 & Klickitat & Klickitat & 11.1 & $\mathrm{Rb}$ & 90 & trib. \#3 on north side of Klickitat River \\
\hline $8 / 20$ & Unnamed \#3 & Klickitat & Klickitat & 11.1 & $\mathrm{Rb}$ & 75 & trib. \#3 on north side of Klickitat River \\
\hline $8 / 20$ & Unnamed \#3 & Klickitat & Klickitat & 11.1 & $\mathrm{Rb}$ & 80 & trib. \#3 on north side of Klickitat River \\
\hline $8 / 20$ & Unnamed \#3 & Klickitat & Klickitat & 11.1 & $\mathrm{Rb}$ & 125 & trib. \#3 on north side of Klickitat River \\
\hline $8 / 20$ & Unnamed \#3 & Klickitat & Klickitat & 11.1 & $\mathrm{Rb}$ & 119 & trib. \#3 on north side of Klickitat River \\
\hline $8 / 20$ & Unnamed \#3 & Klickitat & Klickitat & 11.1 & $\mathrm{Rb}$ & 142 & trib. \#3 on north side of Klickitat River \\
\hline $8 / 20$ & Unnamed \#3 & Klickitat & Klickitat & 11.1 & $\mathrm{Rb}$ & 74 & trib. \#3 on north side of Klickitat River \\
\hline $8 / 20$ & Unnamed \#3 & Klickitat & Klickitat & 11.1 & $\mathrm{Rb}$ & 140 & trib. \#3 on north side of Klickitat River \\
\hline $8 / 20$ & Unnamed \#3 & Klickitat & Klickitat & 11.1 & $\mathrm{Rb}$ & 138 & north fork of trib. \#3 on north side of Klickitat River \\
\hline $8 / 20$ & Unnamed \#3 & Klickitat & Klickitat & 11.1 & $\mathrm{Rb}$ & 134 & east fork of trib. \#3 on north side of Klickitat River \\
\hline $8 / 20$ & Unnamed \#3 & Klickitat & Klickitat & 11.1 & $\mathrm{Rb}$ & 123 & east fork of trib. \#3 on north side of Klickitat River \\
\hline $8 / 20$ & Unnamed \#3 & Klickitat & Klickitat & 11.1 & $\mathrm{Rb}$ & 121 & east fork of trib. \#3 on north side of Klickitat River \\
\hline $8 / 20$ & Unnamed \#3 & Klickitat & Klickitat & 11.1 & $\mathrm{Rb}$ & 171 & east fork of trib. \#3 on north side of Klickitat River \\
\hline $8 / 20$ & Unnamed \#3 & Klickitat & Klickitat & 11.1 & $\mathrm{Rb}$ & 132 & east fork of trib. \#3 on north side of Klickitat River \\
\hline $8 / 20$ & Unnamed \#3 & Klickitat & Klickitat & 11.1 & $\mathrm{Rb}$ & 127 & east fork of trib. \#3 on north side of Klickitat River \\
\hline $11 / 5$ & Butler & Little Klickitat & Klickitat & 2 & $\mathrm{Rb}$ & 116 & mid Butler Creek at end of road in canyon \\
\hline $11 / 5$ & Butler & Little Klickitat & Klickitat & 2 & $\mathrm{Rb}$ & 113 & mid Butler Creek at end of road in canyon \\
\hline $11 / 5$ & Butler & Little Klickitat & Klickitat & 2 & $\mathrm{Rb}$ & 150 & mid Butler Creek at end of road in canyon \\
\hline $11 / 5$ & Butler & Little Klickitat & Klickitat & 2 & $\mathrm{Rb}$ & 105 & mid Butler Creek at end of road in canyon \\
\hline $11 / 5$ & Butler & Little Klickitat & Klickitat & 2 & $\mathrm{Rb}$ & 124 & mid Butler Creek at end of road in canyon \\
\hline $11 / 5$ & Butler & Little Klickitat & Klickitat & 2 & $\mathrm{Rb}$ & 95 & mid Butler Creek at end of road in canyon \\
\hline $11 / 5$ & Butler & Little Klickitat & Klickitat & 2 & $\mathrm{Rb}$ & 92 & mid Butler Creek at end of road in canyon \\
\hline $11 / 5$ & Butler & Little Klickitat & Klickitat & 2 & $\mathrm{Rb}$ & 100 & mid Butler Creek at end of road in canyon \\
\hline $11 / 5$ & Butler & Little Klickitat & Klickitat & 2 & $\mathrm{Rb}$ & 94 & mid Butler Creek at end of road in canyon \\
\hline $11 / 5$ & Butler & Little Klickitat & Klickitat & 2 & $\mathrm{Rb}$ & 65 & mid Butler Creek at end of road in canyon \\
\hline $11 / 5$ & Butler & Little Klickitat & Klickitat & $\frac{L}{2}$ & $\mathrm{Rb}$ & 95 & mid Butler Creek at end of road in canyon \\
\hline $11 / 5$ & Butler & Little Klickitat & Klickitat & 2 & $\mathrm{Rb}$ & 62 & mid Butler Creek at end of road in canyon \\
\hline $11 / 5$ & Butler & Little Klickitat & Klickitat & 2 & $\mathrm{Rb}$ & 102 & mid Butler Creek at end of road in canyon \\
\hline $11 / 5$ & Butler & Little Klickitat & Klickitat & 2 & $\mathrm{Rb}$ & 53 & mid Butler Creek at end of road in canyon \\
\hline $11 / 5$ & Butler & Little Klickitat & Klickitat & 2 & $\mathrm{Rb}$ & 117 & mid Butler Creek at end of road in canyon \\
\hline $11 / 5$ & Butler & \begin{tabular}{|l|} 
Little Klickitat \\
\end{tabular} & \begin{tabular}{|l} 
Klickitat \\
\end{tabular} & 2 & $\mathrm{Rb}$ & 68 & mid Butler Creek at end of road in canyon \\
\hline $11 / 5$ & Butler & Little Klickitat & Klickitat & 2 & $\mathrm{Rb}$ & 60 & mid Butler Creek at end of road in canyon \\
\hline $11 / 5$ & Butler & Little Klickitat & Klickitat & 2 & $\mathrm{Rb}$ & 101 & mid Butler Creek at end of road in canyon \\
\hline $11 / 5$ & Butler & Little Klickitat & Klickitat & 2 & $\mathrm{Rb}$ & 54 & mid Butler Creek at end of road in canyon \\
\hline $11 / 5$ & Butler & Little Klickitat & Klickitat & 2 & $\mathrm{Rb}$ & 55 & mid Butler Creek at end of road in canyon \\
\hline $11 / 5$ & Butler & Little Klickitat & Klickitat & 2 & $\mathrm{Rb}$ & 48 & mid Butler Creek at end of road in canyon \\
\hline $11 / 5$ & Butler & Little Klickitat & Klickitat & 2 & $\mathrm{Rb}$ & 58 & mid Butler Creek at end of road in canyon \\
\hline $11 / 5$ & Butler & Little Klickitat & Klickitat & 2 & $\mathrm{Rb}$ & 56 & mid Butler Creek at end of road in canyon \\
\hline
\end{tabular}


Appendix C. Electroshock data from streams in the Klickitat and White Salmon river basins, 2001.

\begin{tabular}{|c|c|c|c|c|c|c|c|}
\hline $11 / 5$ & Butler & Little Klickitat & Klickitat & 2 & $\mathrm{Rb}$ & 54 & mid Butler Creek at end of road in canyon \\
\hline $11 / 5$ & Butler & Little Klickitat & Klickitat & 2 & $\mathrm{Rb}$ & 53 & mid Butler Creek at end of road in canyon \\
\hline $11 / 5$ & Butler & Little Klickitat & Klickitat & 2 & $\mathrm{Rb}$ & 80 & mid Butler Creek at end of road in canyon \\
\hline $11 / 5$ & Butler & Little Klickitat & Klickitat & 2 & $\mathrm{Rb}$ & 64 & mid Butler Creek at end of road in canyon \\
\hline $11 / 5$ & Butler & Little Klickitat & Klickitat & 2 & $\mathrm{Rb}$ & 53 & mid Butler Creek at end of road in canyon \\
\hline $11 / 5$ & Butler & Little Klickitat & Klickitat & 2 & $\mathrm{Rb}$ & 54 & mid Butler Creek at end of road in canyon \\
\hline $11 / 5$ & Butler & Little Klickitat & Klickitat & 2 & $\mathrm{Rb}$ & 87 & mid Butler Creek at end of road in canyon \\
\hline $11 / 5$ & Butler & Little Klickitat & Klickitat & 2 & $\mathrm{Rb}$ & 55 & mid Butler Creek at end of road in canyon \\
\hline $11 / 5$ & Butler & Little Klickitat & Klickitat & 2 & $\mathrm{Rb}$ & 98 & mid Butler Creek at end of road in canyon \\
\hline $11 / 5$ & Butler & Little Klickitat & Klickitat & 2 & $\mathrm{Rb}$ & 58 & mid Butler Creek at end of road in canyon \\
\hline $11 / 5$ & Butler & Little Klickitat & Klickitat & 2 & $\mathrm{Rb}$ & 62 & mid Butler Creek at end of road in canyon \\
\hline $11 / 5$ & Butler & Little Klickitat & Klickitat & 2 & $\mathrm{Rb}$ & 60 & mid Butler Creek at end of road in canyon \\
\hline $11 / 5$ & Butler & Little Klickitat & Klickitat & 2 & $\mathrm{Rb}$ & 53 & mid Butler Creek at end of road in canyon \\
\hline $11 / 6$ & Butler & Little Klickitat & Klickitat & 0.5 & $\mathrm{Rb}$ & 113 & upper Butler Creek \\
\hline $11 / 6$ & Butler & Little Klickitat & Klickitat & 0.5 & $\mathrm{Rb}$ & 94 & upper Butler Creek \\
\hline $11 / 6$ & Butler & Little Klickitat & Klickitat & 0.5 & $\mathrm{Rb}$ & 77 & upper Butler Creek \\
\hline $11 / 6$ & Butler & Little Klickitat & Klickitat & 0.5 & $\mathrm{Rb}$ & 69 & upper Butler Creek \\
\hline $11 / 6$ & Butler & Little Klickitat & Klickitat & 0.5 & $\mathrm{Rb}$ & 51 & upper Butler Creek \\
\hline $11 / 6$ & Butler & Little Klickitat & Klickitat & 0.5 & $\mathrm{Rb}$ & 79 & upper Butler Creek \\
\hline $11 / 6$ & Butler & Little Klickitat & Klickitat & 0.5 & $\mathrm{Rb}$ & 89 & upper Butler Creek \\
\hline $11 / 6$ & Butler & Little Klickitat & Klickitat & 0.5 & $\mathrm{Rb}$ & 47 & upper Butler Creek \\
\hline $11 / 6$ & Butler & Little Klickitat & Klickitat & 0.5 & $\mathrm{Rb}$ & 86 & upper Butler Creek \\
\hline $11 / 6$ & Butler & Little Klickitat & Klickitat & 0.5 & $\mathrm{Rb}$ & 73 & upper Butler Creek \\
\hline $11 / 6$ & Butler & Little Klickitat & Klickitat & 0.5 & $\mathrm{Rb}$ & 48 & upper Butler Creek \\
\hline $11 / 6$ & Butler & Little Klickitat & Klickitat & 0.5 & $\mathrm{Rb}$ & 80 & upper Butler Creek \\
\hline $11 / 6$ & Butler & \begin{tabular}{|l} 
Little Klickitat \\
\end{tabular} & Klickitat & 0.5 & $\mathrm{Rb}$ & 92 & upper Butler Creek \\
\hline $11 / 6$ & Butler & Little Klickitat & Klickitat & 0.5 & $\mathrm{Rb}$ & 104 & upper Butler Creek \\
\hline $11 / 6$ & Butler & \begin{tabular}{|l} 
Little Klickitat \\
\end{tabular} & Klickitat & 0.5 & $\mathrm{Rb}$ & 97 & upper Butler Creek \\
\hline $11 / 6$ & Butler & Little Klickitat & Klickitat & 0.5 & $\mathrm{Rb}$ & 98 & upper Butler Creek \\
\hline $11 / 6$ & Butler & Little Klickitat & Klickitat & 0.5 & $\mathrm{Rb}$ & 76 & upper Butler Creek \\
\hline $11 / 6$ & Butler & Little Klickitat & Klickitat & 0.5 & $\mathrm{Rb}$ & 168 & upper Butler Creek \\
\hline $11 / 6$ & Butler & Little Klickitat & Klickitat & 0.5 & $\mathrm{Rb}$ & 72 & upper Butler Creek \\
\hline $11 / 6$ & Butler & \begin{tabular}{|l} 
Little Klickitat \\
\end{tabular} & Klickitat & 0.5 & $\mathrm{Rb}$ & 173 & upper Butler Creek \\
\hline $11 / 6$ & Butler & Little Klickitat & Klickitat & 0.5 & $\mathrm{Rb}$ & 169 & upper Butler Creek \\
\hline $11 / 6$ & Butler & Little Klickitat & Klickitat & 0.5 & $\mathrm{Rb}$ & 90 & upper Butler Creek \\
\hline $11 / 6$ & Butler & Little Klickitat & Klickitat & 0.5 & $\mathrm{Rb}$ & 100 & upper Butler Creek \\
\hline $11 / 6$ & Butler & \begin{tabular}{|l} 
Little Klickitat \\
\end{tabular} & Klickitat & 0.5 & $\mathrm{Rb}$ & 49 & upper Butler Creek \\
\hline $11 / 6$ & Butler & Little Klickitat & Klickitat & 0.5 & $\mathrm{Rb}$ & 84 & upper Butler Creek \\
\hline $11 / 6$ & Butler & Little Klickitat & \begin{tabular}{|l} 
Klickitat \\
\end{tabular} & 0.5 & $\mathrm{Rb}$ & 120 & upper Butler Creek \\
\hline $11 / 6$ & Butler & \begin{tabular}{|l} 
Little Klickitat \\
\end{tabular} & \begin{tabular}{|l} 
Klickitat \\
\end{tabular} & 0.5 & $\mathrm{Rb}$ & 40 & upper Butler Creek \\
\hline $11 / 6$ & Butler & Little Klickitat & Klickitat & 0.5 & $\mathrm{Rb}$ & 180 & upper Butler Creek \\
\hline $11 / 6$ & Butler & Little Klickitat & Klickitat & 0.5 & $\mathrm{Rb}$ & 74 & upper Butler Creek \\
\hline $11 / 6$ & Butler & Little Klickitat & Klickitat & 0.5 & $\mathrm{Rb}$ & 165 & upper Butler Creek \\
\hline $11 / 6$ & Butler & Little Klickitat & Klickitat & 0.5 & $\mathrm{Rb}$ & 49 & upper Butler Creek \\
\hline $11 / 6$ & Butler & Little Klickitat & Klickitat & 0.5 & $\mathrm{Rb}$ & 94 & upper Butler Creek \\
\hline $11 / 6$ & Butler & Little Klickitat & Klickitat & 0.5 & $\mathrm{Rb}$ & 81 & upper Butler Creek \\
\hline $11 / 6$ & Butler & Little Klickitat & Klickitat & 0.5 & $\mathrm{Rb}$ & 48 & upper Butler Creek \\
\hline $11 / 6$ & Butler & \begin{tabular}{|l} 
Little Klickitat \\
\end{tabular} & Klickitat & 0.5 & $\mathrm{Rb}$ & 75 & upper Butler Creek \\
\hline $11 / 6$ & Butler & Little Klickitat & Klickitat & 0.5 & $\mathrm{Rb}$ & 108 & upper Butler Creek \\
\hline $11 / 6$ & Butler & Little Klickitat & Klickitat & 0.5 & $\mathrm{Rb}$ & 50 & upper Butler Creek \\
\hline $11 / 6$ & Butler & Little Klickitat & Klickitat & 0.5 & $\mathrm{Rb}$ & 75 & upper Butler Creek \\
\hline $11 / 6$ & Butler & Little Klickitat & Klickitat & 0.5 & $\mathrm{Rb}$ & 48 & upper Butler Creek \\
\hline $11 / 6$ & Butler & Little Klickitat & Klickitat & 0.5 & $\mathrm{Rb}$ & 50 & upper Butler Creek \\
\hline $11 / 6$ & Butler & Little Klickitat & Klickitat & 0 & & & no fish, upper upper Butler Creek \\
\hline $11 / 6$ & West Prong trib. & Little Klickitat & Klickitat & 0 & $\mathrm{Rb}$ & 126 & lower West Prong tributary to east \\
\hline $11 / 6$ & West Prong trib. & Little Klickitat & Klickitat & 0 & $\mathrm{Rb}$ & 122 & lower West Prong tributary to east \\
\hline $11 / 6$ & West Prong trib. & Little Klickitat & Klickitat & 0 & $\mathrm{Rb}$ & 94 & lower West Prong tributary to east \\
\hline $11 / 6$ & West Prong trib. & Little Klickitat & Klickitat & 0 & $\mathrm{Rb}$ & 75 & lower West Prong tributary to east \\
\hline $11 / 6$ & West Prong trib. & Little Klickitat & Klickitat & 0 & $\mathrm{Rb}$ & 75 & lower West Prong tributary to east \\
\hline $11 / 6$ & West Prong & Little Klickitat & Klickitat & 0 & $\mathrm{Rb}$ & 193 & lower West Prong \\
\hline $11 / 6$ & West Prong & \begin{tabular}{|l} 
Little Klickitat \\
\end{tabular} & \begin{tabular}{|l} 
Klickitat \\
\end{tabular} & 0 & $\mathrm{Rb}$ & 95 & lower West Prong \\
\hline $11 / 6$ & West Prong & Little Klickitat & Klickitat & 0 & $\mathrm{Rb}$ & 87 & lower West Prong \\
\hline $11 / 6$ & West Prong & Little Klickitat & Klickitat & 0 & $\mathrm{Rb}$ & 70 & lower West Prong \\
\hline $11 / 6$ & West Prong & Little Klickitat & Klickitat & 0 & $\mathrm{Rb}$ & 110 & lower West Prong \\
\hline $11 / 6$ & West Prong & Little Klickitat & Klickitat & 0 & $\mathrm{Rb}$ & 133 & lower West Prong \\
\hline $11 / 6$ & West Prong & Little Klickitat & Klickitat & 0 & $\mathrm{Rb}$ & 80 & lower West Prong \\
\hline $11 / 6$ & West Prong & Little Klickitat & Klickitat & 0 & $\mathrm{Rb}$ & 100 & lower West Prong \\
\hline $11 / 6$ & West Prong & Little Klickitat & Klickitat & 0 & $\mathrm{Rb}$ & 80 & lower West Prong \\
\hline $11 / 6$ & West Prong & Little Klickitat & Klickitat & 0 & $\mathrm{Rb}$ & 104 & lower West Prong \\
\hline
\end{tabular}


Appendix C. Electroshock data from streams in the Klickitat and White Salmon river basins, 2001.

\begin{tabular}{|c|c|c|c|c|c|c|c|}
\hline $11 / 6$ & West Prong & Little Klickitat & Klickitat & 0 & $\mathrm{Rb}$ & 105 & lower West Prong \\
\hline $11 / 6$ & West Prong & Little Klickitat & \begin{tabular}{|l|} 
Klickitat \\
\end{tabular} & 0 & $\mathrm{Rb}$ & 94 & lower West Prong \\
\hline $11 / 6$ & West Prong & Little Klickitat & Klickitat & 0 & $\mathrm{Rb}$ & 164 & lower West Prong \\
\hline $11 / 6$ & West Prong & Little Klickitat & Klickitat & 0 & $\mathrm{Rb}$ & 125 & lower West Prong \\
\hline $11 / 6$ & West Prong & Little Klickitat & Klickitat & 0 & $\mathrm{Rb}$ & 94 & lower West Prong \\
\hline $11 / 6$ & West Prong & Little Klickitat & Klickitat & 0 & $\mathrm{Rb}$ & 108 & lower West Prong \\
\hline $11 / 6$ & West Prong & Little Klickitat & Klickitat & 0 & $\mathrm{Rb}$ & 160 & lower West Prong \\
\hline $11 / 6$ & West Prong & Little Klickitat & Klickitat & 0 & $\mathrm{Rb}$ & 78 & lower West Prong \\
\hline $11 / 6$ & West Prong & Little Klickitat & Klickitat & 0 & $\mathrm{Rb}$ & 176 & lower West Prong \\
\hline $11 / 6$ & West Prong & Little Klickitat & Klickitat & 0 & $\mathrm{Rb}$ & 69 & lower West Prong \\
\hline $11 / 6$ & West Prong & Little Klickitat & Klickitat & 0 & $\mathrm{Rb}$ & 92 & lower West Prong \\
\hline $11 / 6$ & West Prong & Little Klickitat & Klickitat & 0 & $\mathrm{Rb}$ & 113 & lower West Prong \\
\hline $11 / 6$ & West Prong & Little Klickitat & \begin{tabular}{|l|} 
Klickitat \\
\end{tabular} & 0 & $\mathrm{Rb}$ & 127 & lower West Prong \\
\hline $11 / 6$ & West Prong & Little Klickitat & Klickitat & 0 & $\mathrm{Rb}$ & 100 & lower West Prong \\
\hline $11 / 6$ & West Prong & Little Klickitat & Klickitat & 0 & $\mathrm{Rb}$ & 54 & lower West Prong \\
\hline $11 / 6$ & West Prong & Little Klickitat & Klickitat & 0 & $\mathrm{Rb}$ & 54 & lower West Prong \\
\hline $11 / 6$ & West Prong & Little Klickitat & Klickitat & 0 & $\mathrm{Rb}$ & 76 & lower West Prong \\
\hline $11 / 6$ & West Prong & Little Klickitat & Klickitat & 0 & $\mathrm{Rb}$ & 47 & lower West Prong \\
\hline $11 / 6$ & West Prong & Little Klickitat & Klickitat & 0 & $\mathrm{Rb}$ & 55 & \begin{tabular}{|l} 
lower West Prong \\
\end{tabular} \\
\hline $11 / 6$ & West Prong & Little Klickitat & Klickitat & 0 & $\mathrm{Rb}$ & 93 & lower West Prong \\
\hline $11 / 6$ & West Prong & Little Klickitat & Klickitat & 0 & $\mathrm{Rb}$ & 122 & lower West Prong \\
\hline $11 / 6$ & West Prong & Little Klickitat & Klickitat & 0 & $\mathrm{Rb}$ & 100 & lower West Prong \\
\hline $11 / 6$ & West Prong & Little Klickitat & Klickitat & 0 & $\mathrm{Rb}$ & 95 & lower West Prong \\
\hline $11 / 6$ & West Prong & Little Klickitat & Klickitat & 0 & $\mathrm{Rb}$ & 97 & lower West Prong \\
\hline $11 / 6$ & West Prong & Little Klickitat & Klickitat & 0 & $\mathrm{Rb}$ & 87 & lower West Prong \\
\hline $11 / 6$ & West Prong & Little Klickitat & Klickitat & 0 & $\mathrm{Rb}$ & 47 & lower West Prong \\
\hline $11 / 6$ & West Prong & Little Klickitat & Klickitat & 0 & $\mathrm{Rb}$ & 49 & lower West Prong \\
\hline $11 / 6$ & West Prong & Little Klickitat & Klickitat & 0 & $\mathrm{Rb}$ & 48 & lower West Prong \\
\hline $11 / 6$ & West Prong & Little Klickitat & Klickitat & 0 & $\mathrm{Rb}$ & 42 & lower West Prong \\
\hline $11 / 6$ & West Prong & Little Klickitat & Klickitat & 0 & $\mathrm{Rb}$ & 102 & lower West Prong \\
\hline $11 / 6$ & West Prong & Little Klickitat & Klickitat & 0 & $\mathrm{Rb}$ & 40 & lower West Prong \\
\hline $11 / 6$ & West Prong & Little Klickitat & Klickitat & 0 & $\mathrm{Rb}$ & 45 & lower West Prong \\
\hline $11 / 6$ & West Prong & Little Klickitat & Klickitat & 0 & Sc & 75 & lower West Prong \\
\hline $11 / 6$ & West Prong & Little Klickitat & Klickitat & 0 & Sc & 97 & lower West Prong \\
\hline $11 / 6$ & West Prong & Little Klickitat & Klickitat & 0 & Sc & 94 & lower West Prong \\
\hline $11 / 6$ & West Prong & Little Klickitat & Klickitat & 0 & Sc & 78 & lower West Prong \\
\hline $11 / 6$ & West Prong & Little Klickitat & Klickitat & 0 & Sc & 72 & lower West Prong \\
\hline $11 / 6$ & West Prong & Little Klickitat & Klickitat & 0 & Sc & 98 & lower West Prong \\
\hline $11 / 6$ & West Prong & Little Klickitat & Klickitat & 0 & Sc & 60 & lower West Prong \\
\hline $11 / 6$ & West Prong & Little Klickitat & Klickitat & 0 & Sc & 60 & lower West Prong \\
\hline $11 / 6$ & West Prong & Little Klickitat & Klickitat & 0 & & & no fish; upper West Prong \\
\hline $11 / 12$ & Devils Canyon & \begin{tabular}{|l|} 
Little Klickitat \\
\end{tabular} & Klickitat & 2.5 & $\mathrm{Rb}$ & 145 & \\
\hline $11 / 12$ & Devils Canyon & Little Klickitat & Klickitat & 2.5 & $\mathrm{Rb}$ & 115 & \\
\hline $11 / 12$ & Devils Canyon & Little Klickitat & Klickitat & 2.5 & $\mathrm{Rb}$ & 105 & \\
\hline $11 / 12$ & Devils Canyon & Little Klickitat & Klickitat & 2.5 & $\mathrm{Rb}$ & 70 & \\
\hline $11 / 12$ & Devils Canyon & Little Klickitat & Klickitat & 2.5 & $\mathrm{Rb}$ & 88 & \\
\hline $11 / 12$ & Devils Canyon & Little Klickitat & Klickitat & 2.5 & $\mathrm{Rb}$ & 45 & \\
\hline $11 / 12$ & Devils Canyon & Little Klickitat & Klickitat & 2.5 & $\mathrm{Rb}$ & 47 & \\
\hline $11 / 12$ & Devils Canyon & Little Klickitat & Klickitat & 2.5 & $\mathrm{Rb}$ & 91 & \\
\hline $11 / 12$ & Devils Canyon & Little Klickitat & Klickitat & 2.5 & $\mathrm{Rb}$ & 127 & \\
\hline $11 / 12$ & Devils Canyon & Little Klickitat & Klickitat & 2.5 & $\mathrm{Rb}$ & 108 & \\
\hline $11 / 12$ & Devils Canyon & Little Klickitat & Klickitat & 2.5 & $\mathrm{Rb}$ & 136 & \\
\hline $11 / 12$ & Devils Canyon & Little Klickitat & Klickitat & 2.5 & $\mathrm{Rb}$ & 93 & \\
\hline $11 / 12$ & Devils Canyon & Little Klickitat & \begin{tabular}{|l|} 
Klickitat \\
\end{tabular} & 2.5 & $\mathrm{Rb}$ & 115 & \\
\hline $11 / 12$ & Devils Canyon & Little Klickitat & Klickitat & 2.5 & $\mathrm{Rb}$ & 76 & \\
\hline $11 / 12$ & Devils Canyon & Little Klickitat & Klickitat & 2.5 & $\mathrm{Rb}$ & 94 & \\
\hline $11 / 12$ & Devils Canyon & Little Klickitat & Klickitat & 2.5 & $\mathrm{Rb}$ & 77 & \\
\hline $11 / 12$ & Devils Canyon & Little Klickitat & Klickitat & 2.5 & $\mathrm{Rb}$ & 75 & \\
\hline $11 / 12$ & Devils Canyon & Little Klickitat & Klickitat & 2.5 & $\mathrm{Rb}$ & 66 & \\
\hline $11 / 12$ & Devils Canyon & Little Klickitat & \begin{tabular}{|l|} 
Klickitat \\
\end{tabular} & 2.5 & $\mathrm{Rb}$ & 143 & \\
\hline $11 / 12$ & Devils Canyon & Little Klickitat & Klickitat & 2.5 & $\mathrm{Rb}$ & 91 & \\
\hline $11 / 12$ & Devils Canyon & Little Klickitat & Klickitat & 2.5 & $\mathrm{Rb}$ & 143 & east fork of Devils Canyon, just below confluence of upper two tribs \\
\hline $11 / 12$ & Devils Canyon & Little Klickitat & Klickitat & 2.5 & $\mathrm{Rb}$ & 165 & east fork of Devils Canyon, just below confluence of upper two tribs \\
\hline $11 / 12$ & Devils Canyon & Little Klickitat & Klickitat & 2.5 & $\mathrm{Rb}$ & 127 & east fork of Devils Canyon, just below confluence of upper two tribs \\
\hline $11 / 12$ & Devils Canyon & Little Klickitat & Klickitat & 2.5 & $\mathrm{Rb}$ & 93 & east fork of Devils Canyon, just below confluence of upper two tribs \\
\hline $11 / 12$ & Devils Canyon & Little Klickitat & Klickitat & 2.5 & $\mathrm{Rb}$ & 101 & east fork of Devils Canyon, just below confluence of upper two tribs \\
\hline $11 / 12$ & Devils Canyon & Little Klickitat & Klickitat & 2.5 & $\mathrm{Rb}$ & 155 & east fork of Devils Canyon, just below confluence of upper two tribs \\
\hline $11 / 12$ & Devils Canyon & \begin{tabular}{|l} 
Little Klickitat \\
\end{tabular} & \begin{tabular}{|l} 
Klickitat \\
\end{tabular} & 2.5 & $\mathrm{Rb}$ & 148 & east fork of Devils Canyon, just below confluence of upper two tribs \\
\hline $11 / 12$ & Devils Canyon & Little Klickitat & Klickitat & 2.5 & $\mathrm{Rb}$ & 108 & east fork of Devils Canyon, just below confluence of upper two tribs \\
\hline
\end{tabular}


Appendix C. Electroshock data from streams in the Klickitat and White Salmon river basins, 2001.

\begin{tabular}{|c|c|c|c|c|c|c|c|}
\hline $11 / 12$ & Devils Canyon & Little Klickitat & Klickitat & 2.5 & $\mathrm{Rb}$ & 134 & east fork of Devils Canyon, just below confluence of upper two tribs \\
\hline $11 / 12$ & Devils Canyon & Little Klickitat & Klickitat & 2.5 & $\mathrm{Rb}$ & 142 & east fork of Devils Canyon, just below confluence of upper two tribs \\
\hline $11 / 12$ & Devils Canyon & Little Klickitat & Klickitat & 2.5 & $\mathrm{Rb}$ & 170 & east fork of Devils Canyon, just below confluence of upper two tribs \\
\hline $11 / 12$ & Devils Canyon & Little Klickitat & Klickitat & 2.5 & $\mathrm{Rb}$ & 151 & east fork of Devils Canyon, just below confluence of upper two tribs \\
\hline $11 / 12$ & Devils Canyon & Little Klickitat & Klickitat & 2.5 & $\mathrm{Rb}$ & 150 & east fork of Devils Canyon, just below confluence of upper two tribs \\
\hline $11 / 12$ & Devils Canyon & Little Klickitat & Klickitat & 2.5 & $\mathrm{Rb}$ & 136 & east fork of Devils Canyon, just below confluence of upper two tribs \\
\hline $11 / 12$ & Devils Canyon & Little Klickitat & Klickitat & 2.5 & $\mathrm{Rb}$ & 113 & east fork of Devils Canyon, just below confluence of upper two tribs \\
\hline $11 / 12$ & Devils Canyon & Little Klickitat & Klickitat & 2.5 & $\mathrm{Rb}$ & 45 & east fork of Devils Canyon, just below confluence of upper two tribs \\
\hline $11 / 12$ & Devils Canyon & Little Klickitat & Klickitat & 2.5 & $\mathrm{Rb}$ & 112 & east fork of Devils Canyon, just below confluence of upper two tribs \\
\hline $11 / 12$ & Devils Canyon & Little Klickitat & Klickitat & 2.5 & $\mathrm{Rb}$ & 175 & east fork of Devils Canyon, just below confluence of upper two tribs \\
\hline $11 / 12$ & Devils Canyon & Little Klickitat & Klickitat & 2.5 & $\mathrm{Rb}$ & 138 & east fork of Devils Canyon, just below confluence of upper two tribs \\
\hline $11 / 12$ & Devils Canyon & Little Klickitat & Klickitat & 2.5 & $\mathrm{Rb}$ & 126 & east fork of Devils Canyon, just below confluence of upper two tribs \\
\hline $11 / 12$ & Devils Canyon & Little Klickitat & Klickitat & 2.5 & $\mathrm{Rb}$ & 120 & east fork of Devils Canyon, just below confluence of upper two tribs \\
\hline $11 / 12$ & Devils Canyon & Little Klickitat & Klickitat & 2.5 & $\mathrm{Rb}$ & 108 & east fork of Devils Canyon, just below confluence of upper two tribs \\
\hline $11 / 12$ & Devils Canyon & Little Klickitat & Klickitat & 2.5 & $\mathrm{Rb}$ & 136 & east fork of Devils Canyon, just below confluence of upper two tribs \\
\hline $11 / 12$ & Devils Canyon & Little Klickitat & Klickitat & 2.5 & $\mathrm{Rb}$ & 141 & east fork of Devils Canyon, just below confluence of upper two tribs \\
\hline $11 / 12$ & Devils Canyon & Little Klickitat & Klickitat & 2.5 & $\mathrm{Rb}$ & 191 & east fork of Devils Canyon, just below confluence of upper two tribs \\
\hline $11 / 12$ & Devils Canyon & Little Klickitat & Klickitat & 2.5 & $\mathrm{Rb}$ & 167 & east fork of Devils Canyon, just below confluence of upper two tribs \\
\hline $11 / 12$ & Devils Canyon & Little Klickitat & Klickitat & 2.5 & $\mathrm{Rb}$ & 158 & east fork of Devils Canyon, just below confluence of upper two tribs \\
\hline $11 / 12$ & Devils Canyon & Little Klickitat & Klickitat & 2.5 & $\mathrm{Rb}$ & 140 & east fork of Devils Canyon, just below confluence of upper two tribs \\
\hline $11 / 12$ & Mill & Little Klickitat & Klickitat & 4.3 & $\mathrm{Rb}$ & 115 & east fork of Mill Creek; off closed road on way to west side of Devils Canyon \\
\hline $11 / 12$ & Mill & Little Klickitat & Klickitat & 4.3 & $\mathrm{Rb}$ & 78 & east fork of Mill Creek; off closed road on way to west side of Devils Canyon \\
\hline $11 / 12$ & Mill & Little Klickitat & Klickitat & 4.3 & $\mathrm{Rb}$ & 133 & east fork of Mill Creek; off closed road on way to west side of Devils Canyon \\
\hline $11 / 12$ & Mill & Little Klickitat & Klickitat & 4.3 & $\mathrm{Rb}$ & 108 & east fork of Mill Creek; off closed road on way to west side of Devils Canyon \\
\hline $11 / 12$ & Mill & Little Klickitat & Klickitat & 4.3 & $\mathrm{Rb}$ & 104 & east fork of Mill Creek; off closed road on way to west side of Devils Canyon \\
\hline $11 / 12$ & Mill & Little Klickitat & Klickitat & 4.3 & $\mathrm{Rb}$ & 80 & east fork of Mill Creek; off closed road on way to west side of Devils Canyon \\
\hline $11 / 12$ & Mill & Little Klickitat & Klickitat & 4.3 & $\mathrm{Rb}$ & 47 & east fork of Mill Creek; off closed road on way to west side of Devils Canyon \\
\hline $11 / 12$ & Mill & Little Klickitat & Klickitat & 4.3 & $\mathrm{Rb}$ & 82 & east fork of Mill Creek; off closed road on way to west side of Devils Canyon \\
\hline $11 / 12$ & Mill & Little Klickitat & Klickitat & 4.3 & $\mathrm{Rb}$ & 118 & east fork of Mill Creek; off closed road on way to west side of Devils Canyon \\
\hline $11 / 12$ & Mill & Little Klickitat & Klickitat & 4.3 & $\mathrm{Rb}$ & 87 & east fork of Mill Creek; off closed road on way to west side of Devils Canyon \\
\hline $11 / 12$ & Mill & Little Klickitat & Klickitat & 4.3 & $\mathrm{Rb}$ & 158 & east fork of Mill Creek; off closed road on way to west side of Devils Canyon \\
\hline $11 / 12$ & Mill & Little Klickitat & Klickitat & 4.3 & $\mathrm{Rb}$ & 118 & east fork of Mill Creek; off closed road on way to west side of Devils Canyon \\
\hline $11 / 12$ & Mill & Little Klickitat & Klickitat & 4.3 & $\mathrm{Rb}$ & 132 & east fork of Mill Creek; off closed road on way to west side of Devils Canyon \\
\hline $11 / 12$ & Mill & Little Klickitat & Klickitat & 4.3 & $\mathrm{Rb}$ & 126 & east fork of Mill Creek; off closed road on way to west side of Devils Canyon \\
\hline $11 / 12$ & Mill & Little Klickitat & Klickitat & 4.3 & $\mathrm{Rb}$ & 126 & east fork of Mill Creek; off closed road on way to west side of Devils Canyon \\
\hline $11 / 12$ & Mill & Little Klickitat & Klickitat & 4.3 & $\mathrm{Rb}$ & 90 & east fork of Mill Creek; off closed road on way to west side of Devils Canyon \\
\hline $11 / 12$ & Mill & Little Klickitat & Klickitat & 4.3 & $\mathrm{Rb}$ & 103 & east fork of Mill Creek; off closed road on way to west side of Devils Canyon \\
\hline $11 / 12$ & Mill & Little Klickitat & Klickitat & 4.3 & $\mathrm{Rb}$ & 115 & east fork of Mill Creek; off closed road on way to west side of Devils Canyon \\
\hline $11 / 12$ & Mill & Little Klickitat & Klickitat & 4.3 & $\mathrm{Rb}$ & 100 & east fork of Mill Creek; off closed road on way to west side of Devils Canyon \\
\hline $11 / 12$ & Mill & Little Klickitat & Klickitat & 4.3 & $\mathrm{Rb}$ & 82 & east fork of Mill Creek; off closed road on way to west side of Devils Canyon \\
\hline $11 / 12$ & Mill & Little Klickitat & Klickitat & 4.3 & $\mathrm{Rb}$ & 119 & east fork of Mill Creek; off closed road on way to west side of Devils Canyon \\
\hline $11 / 12$ & Mill & Little Klickitat & Klickitat & 4.3 & $\mathrm{Rb}$ & 67 & east fork of Mill Creek; off closed road on way to west side of Devils Canyon \\
\hline $11 / 12$ & Mill & Little Klickitat & Klickitat & 4.3 & $\mathrm{Rb}$ & 76 & east fork of Mill Creek; off closed road on way to west side of Devils Canyon \\
\hline $8 / 28$ & Chaparral & Klickitat & Klickitat & 11.7 & $\mathrm{Rb}$ & 72 & \\
\hline $8 / 28$ & Chaparral & Klickitat & Klickitat & 11.7 & $\mathrm{Rb}$ & 53 & \\
\hline $8 / 28$ & Chaparral & Klickitat & Klickitat & 11.7 & $\mathrm{Rb}$ & 130 & \\
\hline $8 / 28$ & Chaparral & Klickitat & Klickitat & 11.7 & $\mathrm{Rb}$ & 63 & \\
\hline $8 / 28$ & Chaparral & Klickitat & Klickitat & 11.7 & $\mathrm{Rb}$ & 58 & \\
\hline $8 / 28$ & Chaparral & Klickitat & Klickitat & 11.7 & $\mathrm{Rb}$ & 73 & \\
\hline $8 / 28$ & Chaparral & Klickitat & Klickitat & 11.7 & $\mathrm{Rb}$ & 81 & \\
\hline $8 / 28$ & Chaparral & Klickitat & Klickitat & 11.7 & $\mathrm{Rb}$ & 52 & \\
\hline $8 / 28$ & Chaparral & Klickitat & Klickitat & 11.7 & $\mathrm{Rb}$ & 75 & \\
\hline $8 / 28$ & Chaparral & Klickitat & Klickitat & 11.7 & $\mathrm{Rb}$ & 76 & \\
\hline $8 / 28$ & Chaparral & Klickitat & Klickitat & 11.7 & $\mathrm{Rb}$ & 87 & \\
\hline $8 / 28$ & Chaparral & Klickitat & Klickitat & 11.7 & $\mathrm{Rb}$ & 53 & \\
\hline $8 / 28$ & Chaparral & Klickitat & Klickitat & 11.7 & $\mathrm{Rb}$ & 53 & \\
\hline $8 / 28$ & Chaparral & Klickitat & Klickitat & 11.7 & $\mathrm{Rb}$ & 58 & \\
\hline $8 / 28$ & Chaparral & Klickitat & Klickitat & 11.7 & $\mathrm{Rb}$ & 60 & \\
\hline $8 / 28$ & Chaparral & Klickitat & Klickitat & 11.7 & $\mathrm{Rb}$ & 57 & \\
\hline $8 / 28$ & Chaparral & Klickitat & Klickitat & 11.7 & $\mathrm{Rb}$ & 98 & \\
\hline $8 / 28$ & Chaparral & Klickitat & Klickitat & 11.7 & $\mathrm{Rb}$ & 53 & \\
\hline $8 / 28$ & Chaparral & Klickitat & Klickitat & 11.7 & $\mathrm{Rb}$ & 78 & \\
\hline $8 / 28$ & Chaparral & Klickitat & Klickitat & 11.7 & $\mathrm{Rb}$ & 31 & \\
\hline $8 / 28$ & Chaparral & Klickitat & Klickitat & 11.7 & $\mathrm{Rb}$ & 32 & \\
\hline $8 / 28$ & Chaparral & Klickitat & Klickitat & 11.7 & $\mathrm{Rb}$ & 57 & \\
\hline $8 / 28$ & Chaparral & Klickitat & Klickitat & 11.7 & $\mathrm{Rb}$ & 74 & \\
\hline $8 / 28$ & Chaparral & Klickitat & Klickitat & 11.7 & $\mathrm{Rb}$ & 58 & \\
\hline $8 / 28$ & Chaparral & Klickitat & Klickitat & 11.7 & $\mathrm{Rb}$ & 97 & \\
\hline $8 / 27$ & Unnamed & Klickitat & Klickitat & 6.1 & & & no fish; unnamed trib to Klickitat at RM 91.8, north bank \\
\hline
\end{tabular}


Appendix C. Electroshock data from streams in the Klickitat and White Salmon river basins, 2001.

\begin{tabular}{|c|c|c|c|c|c|c|c|}
\hline $8 / 27$ & Klickitat & Columbia & Klickitat & 11.7 & $\mathrm{Rb}$ & & shocked 2 Rbs \\
\hline $7 / 31$ & Unnamed & Klickitat & Klickitat & 9.8 & $\mathrm{Rb}$ & & \begin{tabular}{|l|} 
shocked 9 Rbs ( 4 fry, 4 parr, $1<150$ ) \\
\end{tabular} \\
\hline $7 / 31$ & Unnamed & Klickitat & Klickitat & 9.8 & Bk & 95 & \\
\hline $8 / 15$ & Piscoe & Klickitat & Klickitat & 15 & $\mathrm{Rb}$ & 152 & upper Piscoe off Piscoe Creek Rd. \\
\hline $8 / 15$ & Piscoe & Klickitat & Klickitat & 15 & $\mathrm{Rb}$ & 105 & upper Piscoe off Piscoe Creek Rd. \\
\hline $8 / 15$ & Piscoe & Klickitat & Klickitat & 15 & $\mathrm{Rb}$ & 65 & upper Piscoe off Piscoe Creek Rd. \\
\hline $8 / 15$ & Piscoe & Klickitat & Klickitat & 15 & $\mathrm{Rb}$ & 72 & upper Piscoe off Piscoe Creek Rd. \\
\hline $8 / 15$ & Piscoe & Klickitat & Klickitat & 15 & $\mathrm{Rb}$ & 70 & upper Piscoe off Piscoe Creek Rd. \\
\hline $8 / 15$ & Piscoe & Klickitat & Klickitat & 15 & $\mathrm{Rb}$ & 145 & upper Piscoe off Piscoe Creek Rd. \\
\hline $8 / 15$ & Piscoe & Klickitat & Klickitat & 15 & $\mathrm{Rb}$ & 100 & upper Piscoe off Piscoe Creek Rd. \\
\hline $8 / 15$ & Piscoe & Klickitat & Klickitat & 15 & $\mathrm{Rb}$ & 120 & upper Piscoe off Piscoe Creek Rd. \\
\hline $8 / 15$ & Piscoe & Klickitat & Klickitat & 15 & $\mathrm{Rb}$ & 105 & upper Piscoe off Piscoe Creek Rd. \\
\hline $8 / 15$ & Piscoe & Klickitat & Klickitat & 15 & $\mathrm{Rb}$ & 174 & upper Piscoe off Piscoe Creek Rd. \\
\hline $8 / 15$ & Piscoe & Klickitat & Klickitat & 15 & $\mathrm{Rb}$ & 100 & upper Piscoe off Piscoe Creek Rd. \\
\hline $8 / 15$ & Piscoe & Klickitat & Klickitat & 15 & $\mathrm{Rb}$ & 110 & upper Piscoe off Piscoe Creek Rd. \\
\hline $8 / 15$ & Piscoe & Klickitat & Klickitat & 15 & $\mathrm{Rb}$ & 174 & upper Piscoe off Piscoe Creek Rd. \\
\hline $8 / 15$ & Piscoe & Klickitat & Klickitat & 15 & $\mathrm{Rb}$ & 114 & upper Piscoe off Piscoe Creek Rd. \\
\hline $8 / 15$ & Piscoe & Klickitat & Klickitat & 15 & $\mathrm{Rb}$ & 102 & upper Piscoe off Piscoe Creek Rd. \\
\hline $8 / 15$ & Piscoe & Klickitat & Klickitat & 15 & $\mathrm{Rb}$ & 95 & upper Piscoe off Piscoe Creek Rd. \\
\hline $8 / 15$ & Piscoe & Klickitat & Klickitat & 15 & $\mathrm{Rb}$ & 97 & upper Piscoe off Piscoe Creek Rd. \\
\hline $8 / 15$ & Piscoe & Klickitat & Klickitat & 15 & $\mathrm{Rb}$ & 120 & upper Piscoe off Piscoe Creek Rd. \\
\hline $8 / 15$ & Piscoe & Klickitat & Klickitat & 15 & $\mathrm{Rb}$ & 100 & upper Piscoe off Piscoe Creek Rd. \\
\hline $8 / 15$ & Piscoe & Klickitat & Klickitat & 15 & $\mathrm{Rb}$ & 67 & upper Piscoe off Piscoe Creek Rd. \\
\hline $8 / 15$ & Piscoe & Klickitat & Klickitat & 15 & $\mathrm{Rb}$ & 75 & upper Piscoe off Piscoe Creek Rd. \\
\hline $8 / 15$ & Piscoe & Klickitat & Klickitat & 15 & $\mathrm{Rb}$ & 78 & upper Piscoe off Piscoe Creek Rd. \\
\hline $8 / 15$ & Piscoe & Klickitat & Klickitat & 15 & $\mathrm{Rb}$ & 119 & upper Piscoe off Piscoe Creek Rd. \\
\hline $8 / 15$ & Piscoe & Klickitat & Klickitat & 15 & $\mathrm{Rb}$ & 111 & upper Piscoe off Piscoe Creek Rd. \\
\hline $8 / 15$ & Piscoe & Klickitat & Klickitat & 15 & $\mathrm{Rb}$ & 154 & upper Piscoe off Piscoe Creek Rd. \\
\hline $8 / 15$ & Piscoe & Klickitat & Klickitat & 15 & $\mathrm{Rb}$ & 113 & upper Piscoe off Piscoe Creek Rd. \\
\hline $8 / 15$ & Piscoe & Klickitat & Klickitat & 15 & $\mathrm{Rb}$ & 97 & upper Piscoe off Piscoe Creek Rd. \\
\hline $8 / 15$ & Piscoe & Klickitat & Klickitat & 15 & $\mathrm{Rb}$ & 97 & upper Piscoe off Piscoe Creek Rd. \\
\hline $8 / 15$ & Piscoe & Klickitat & Klickitat & 15 & $\mathrm{Rb}$ & 118 & upper Piscoe off Piscoe Creek Rd. \\
\hline $8 / 15$ & Piscoe & Klickitat & Klickitat & 15 & $\mathrm{Rb}$ & 115 & upper Piscoe off Piscoe Creek Rd. \\
\hline $8 / 15$ & Piscoe & Klickitat & Klickitat & 15 & $\mathrm{Rb}$ & 106 & upper Piscoe off Piscoe Creek Rd. \\
\hline $8 / 15$ & Piscoe & Klickitat & Klickitat & 15 & $\mathrm{Rb}$ & 64 & upper Piscoe off Piscoe Creek Rd. \\
\hline $8 / 15$ & Piscoe & Klickitat & Klickitat & 15 & $\mathrm{Rb}$ & 118 & upper Piscoe off Piscoe Creek Rd. \\
\hline $8 / 15$ & Piscoe & Klickitat & Klickitat & 15 & $\mathrm{Rb}$ & 57 & upper Piscoe off Piscoe Creek Rd. \\
\hline $8 / 15$ & Piscoe & Klickitat & Klickitat & 15 & $\mathrm{Rb}$ & 72 & upper Piscoe off Piscoe Creek Rd. \\
\hline $8 / 15$ & Piscoe & Klickitat & Klickitat & 15 & $\mathrm{Rb}$ & 67 & upper Piscoe off Piscoe Creek Rd. \\
\hline $8 / 15$ & Piscoe & Klickitat & Klickitat & 15 & $\mathrm{Rb}$ & 61 & upper Piscoe off Piscoe Creek Rd. \\
\hline $8 / 15$ & Piscoe & Klickitat & Klickitat & 15 & $\mathrm{Rb}$ & 74 & upper Piscoe off Piscoe Creek Rd. \\
\hline $8 / 15$ & Piscoe & Klickitat & Klickitat & 15 & $\mathrm{Rb}$ & 62 & upper Piscoe off Piscoe Creek Rd. \\
\hline $8 / 15$ & Piscoe & Klickitat & Klickitat & 15 & $\mathrm{Rb}$ & 107 & upper Piscoe off Piscoe Creek Rd. \\
\hline $8 / 15$ & Piscoe & Klickitat & Klickitat & 15 & $\mathrm{Rb}$ & 130 & upper Piscoe off Piscoe Creek Rd. \\
\hline $8 / 15$ & Piscoe & Klickitat & Klickitat & 15 & $\mathrm{Rb}$ & 93 & upper Piscoe off Piscoe Creek Rd. \\
\hline $8 / 15$ & Piscoe & Klickitat & Klickitat & 15 & $\mathrm{Rb}$ & 82 & upper Piscoe off Piscoe Creek Rd. \\
\hline $8 / 15$ & Piscoe & Klickitat & Klickitat & 15 & $\mathrm{Rb}$ & 93 & upper Piscoe off Piscoe Creek Rd. \\
\hline $8 / 15$ & Piscoe & Klickitat & Klickitat & 15 & $\mathrm{Rb}$ & 122 & upper Piscoe off Piscoe Creek Rd. \\
\hline $8 / 15$ & Piscoe & Klickitat & Klickitat & 15 & $\mathrm{Rb}$ & 70 & upper Piscoe off Piscoe Creek Rd. \\
\hline $8 / 15$ & Piscoe & Klickitat & Klickitat & 15 & $\mathrm{Rb}$ & 104 & upper Piscoe off Piscoe Creek Rd. \\
\hline $8 / 15$ & Piscoe & Klickitat & Klickitat & 15 & $\mathrm{Rb}$ & 87 & upper Piscoe off Piscoe Creek Rd. \\
\hline
\end{tabular}

